
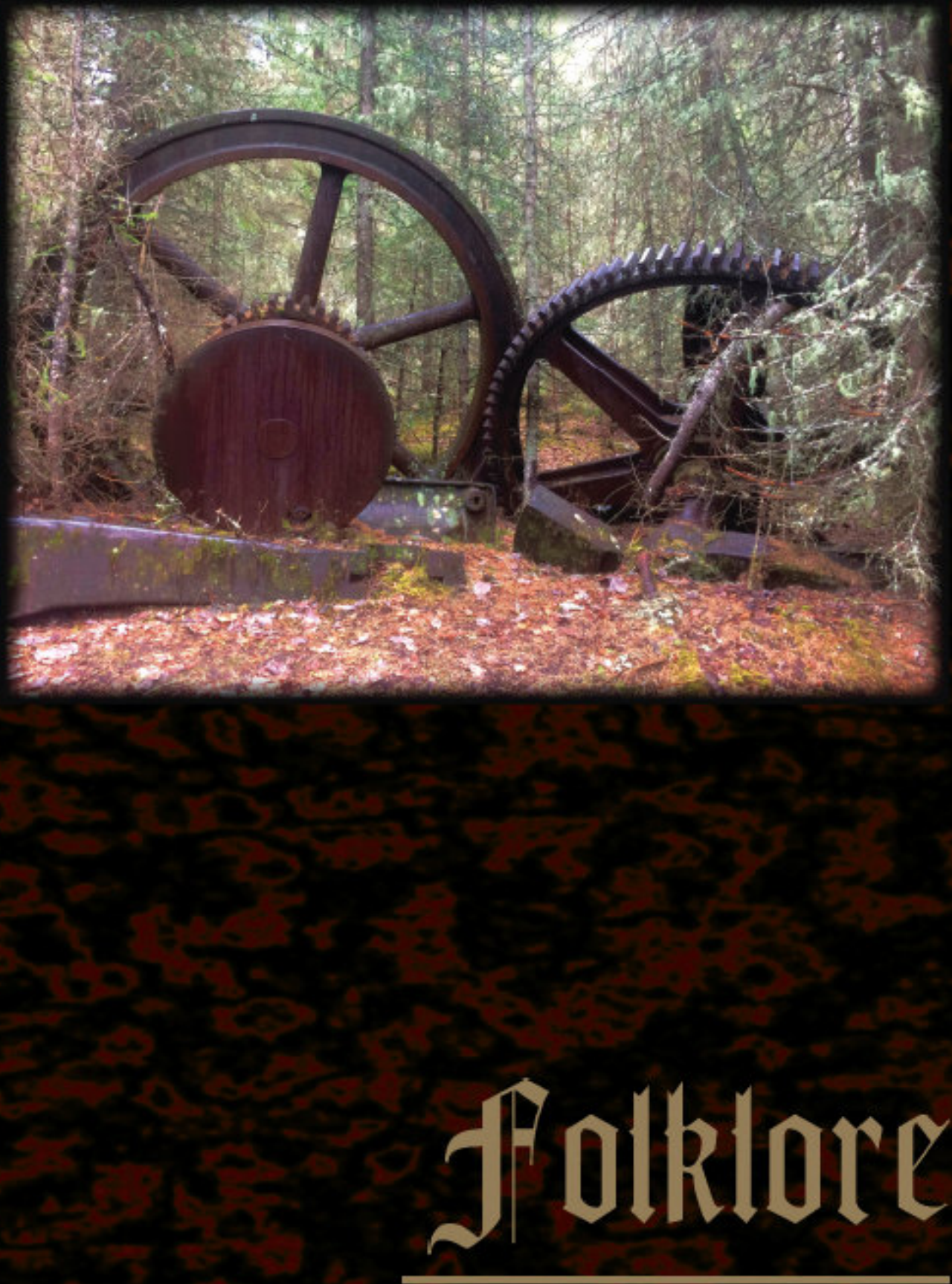

Electronic Journal of Folklore 76 


\section{Folklore}

Electronic Journal of Folklore http://www.folklore.ee/folklore Vol. 76

2019 
Folk Belief and Media Group

of the Estonian Literary Museum

Estonian Institute of Folklore

\section{Folklore}

Electronic Journal of Folklore

Vol. 76

Edited by Mare Kõiva \& Andres Kuperjanov

Guest editors Liudmila Lobanova \&

Nikolay Kuznetsov

ELM Scholarly Press

Tartu 2019 
Editor in chief

Co-editor

Guest editors

Copy editor

News and reviews

Design

Layout
Mare Kõiva

Andres Kuperjanov

Liudmila Lobanova \& Nikolay Kuznetsov

Tiina Mällo

Piret Voolaid

Andres Kuperjanov

Diana Kahre

Editorial board 2015-2020: Dan Ben-Amos (University of Pennsylvania, USA), Larisa Fialkova (University of Haifa, Israel), Diane Goldstein (Indiana University, USA), Terry Gunnell (University of Iceland), Jawaharlal Handoo (University of Mysore, India), Frank Korom (Boston University, USA), Jurij Fikfak (Institute of Slovenian Ethnology), Ülo Valk (University of Tartu, Estonia), Wolfgang Mieder (University of Vermont, USA), Irina Sedakova (Russian Academy of Sciences).

The journal is supported by the Estonian Ministry of Education and Research (IUT 22-5), the European Union through the European Regional Development Fund (Centre of Excellence in Estonian Studies), and the Estonian Literary Museum.

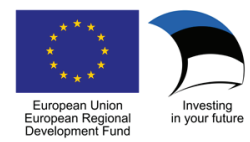

Indexed in EBSCO Publishing Humanities International Complete, Clarivate Analytics Web of Science (Arts \& Humanities Citation Index), MLA International Bibliography, Ulrich's Periodicals Directory, Internationale Volkskundliche Bibliographie / International Folklore Bibliography / Bibliographie Internationale d'Ethnologie, Open Folklore, C.E.E.O.L., Scopus

\section{Editorial address:}

Folklore: Electronic Journal of Folklore

Vanemuise 42-235

51003 Tartu

Estonia

phone: $\quad+3727377740$

fax: $\quad+3727377706$

e-mail: folklore@folklore.ee

home page: http://www.folklore.ee/folklore

All rights reserved

(C) Estonian Literary Museum

Estonian Institute of Folklore

Authors

Design Andres Kuperjanov

According to Creative Commons licence BY-NC-ND 4.0

ISSN 1406-0957

doi:10.7592/FEJF2019.76 


\section{CONTENTS}

Introduction. Komi Folklore Studies: Connecting Points

Liudmila Lobanova, Nikolay Kuznetsov

Perm and Ob-Ugric Relations in Terms of Folklore Data

Oleg Uliashev

Some Motifs in Komi Legends about the Creation of the World

Pavel Limerov

Zaum (Beyonsense, Educanto) in the Komi Tradition

of Incantations: Revisiting the Issue of Origins

Anatoly Panyukov

Aspects of Studying the Verbal Level of Cattle-Breeding Rituals

Liudmila Lobanova

Calling Upon a Domovoi in the Children's Game Tradition of the Komi

Aleksey Rassykhaev

Tradition of Christmas Youth Gatherings at the Vishera River (Komi Republic)

Galina Savelyeva

Christmas in the Traditions of Russian Mining Settlements of the Komi Republic (as Per Records of the Early

Twenty-First Century)

Yulia Krasheninnikova, Svetlana Nizovtseva

Historical Folklore Prose of the Russian Metallurgical Traditions of the Komi Republic

Yulia Krasheninnikova 
From the Editorial BoARD

Kazakh Diaspora in Kyrgyzstan: History of Settlement and

Ethnographic Peculiarities

Bibiziya Kalshabayeva, Gulnara Dadabayeva, Dauren Eskekbaev

INTERVIEW

Mythology Offers Good Arguments for Solving the Puzzle

of Migration. Interview with Mexican Mythologist Martín

Cuitzeo Domínguez Núñez

Henri Zeigo

Book REview

The Greek Roots of Myth Criticism. Frog 


\section{INTRODUCTION. KOMI FOLKLORE STUDIES: CONNECTING POINTS ${ }^{1}$}

\section{Liudmila Lobanova}

Researcher

Department of Folklore, Institute of Language, Literature, and History

Komi Science Centre, Russian Academy of Sciences, Russia

Email: sergejluda@mail.ru

\section{Nikolay Kuznetsov}

Lecturer in Finno-Ugric Languages

Department of Finno-Ugric Studies

University of Tartu

Email: nikolai.kuznetsov@ut.ee

The special edition of Folklore: Electronic Journal of Folklore is dedicated to $\mathrm{Komi}^{2}$ folklore and folklore studies. The issue was prepared within the framework of cooperation between the Department of Folkloristics of the Estonian Literary Museum and the Folklore Department of the Komi Science Centre by Komi and Estonian folklore researchers. Prior to this, the authors published one of the issues (vol. 17, 2016) of the Sator periodical, which was also dedicated to Komi folklore studies. The goal of this issue is to present some of the results of recent Komi folklore studies to wider academic circles, overcoming the natural linguistic obstacles. The majority of articles are written within the research project "Local Folklore Traditions of the European Northeast of Russia: Mechanisms of Development and Adaptation, System of Genres, Ethnocultural Folklore Interaction" (№ AAAA-A17-117021310066-4).

The history of Komi folklore studies reveals processes typical for the Russian, Soviet, and post-Soviet research dealing with folklore (the research field extended and became more limited over time), as well as studying the Komi language and culture as part of the general development of Finno-Ugric studies. Traditionally, academician Andreas Sjögren (1794-1855) is considered to have discovered Komi folklore - in 1827, he transcribed folklore texts and published them as examples of the Komi language. Other linguistic researchers have used a similar approach to folklore texts. In 1843, Matthias Alexander 
Castrén transcribed Izhma bridal lamentations and published them under the heading Zyrianskie svadebnye pesni (Zyrian Wedding Songs), which is one of the earliest examples of the Izhma Komi ritual poetry (Filippova 2014). Pavel Savvaitov (1815-1895) included bridal lamentations of Upper-Vychegda in his Grammatika zyrianskago iazyka (Grammar of the Zyrian Language, 1850). Yrjö Wichmann, a Finnish linguist and folklore researcher, gathered folklore materials in 1901-1902 and published them as Komi zyrianskaia narodnaia poeziia (Komi-Zyrian Folk Poetry, 1916). The work is peculiar due to the categorisation of folklore materials by local sub-cultures. Hungarian linguist and folklore researcher David Raphael Fokos-Fuchs (1884-1977) presented the material in a similar way in his Obraztsy narodnoi poezii (Samples of Folk Poetry, 1913), Komi teksty (Komi Texts, 1916), and Fol'klor naroda komi (zyrian) (Folklore of Komi (Zyrian) People, 1951) (Filippova 2007). The scientific research of these authors encouraged local intellectuals to start their own work. As a result, Andrei Tsember published two collections of Komi skazki i pesni (Komi Tales and Songs) in 1913 and 1914.

During Wold War II, Estonian academician Paul Ariste and Finnish linguist Toivo Emil Uotila continued collecting folklore from Komi prisoners of war. Later, Nikolay Kuznetsov (2005, 2006, 2008) and Paula Kokkonen (1985-2006) published their own materials. Unlike the previous publications, the collections are categorised by the origin of people, allowing for precise location and attribution. In terms of genre, the texts are mostly songs, tales, lamentations, riddles, and proverbs.

Linguists have made a huge contribution to developing the principles of collecting and publishing folklore texts, such as rules for noting peculiarities in dialect and reflecting these in publications. This allows preserving authenticity, attributing texts to specific dialects and local folklore traditions, determining the location of sources, and using a bilingual approach (usually, texts are transcribed and translated into German, Russian, Finnish, Estonian, or English). Thanks to the work of linguists, Komi folklore has become well known and the publications of the linguists are still researched.

Early twentieth century brings a completely different approach to researching folklore. Folklore texts are considered a source of knowledge about the past of a nation, its culture, and spirituality, as well as the representation of their ethnic identity. Works by Vasily Nalimov, Pitirim Sorokin, and Kallistrat Zhakov serve as classic examples of this approach. Modern methods required new ways for collecting folklore material, and hence, new programmes were developed (Programme 1924), manuals were created (Startsev 1933), and expeditions were organised (Savin 1926; Lobanova 2017).

Literary, civil, and educational organisations and writers soon opted for a new approach, which resulted in the definition of folklore as traditional oral poetry. 
During that time, collections of folklore materials were published. Introductions to these publications described the peculiarities of Komi folklore, its main types, and poetics: Fol'klornyi sbornik (Folklore Collection, 1938) by Pavel Doronin, Viser vozhsa s'ylankyv"ias da moidkyv"ias (Vishera Songs and Tales, 1941) by Ivan Osipov, and Komi moid"ias, s'ylankyv"ias da poslovitsaias (Komi Tales, Songs, and Proverbs, 1956) by Fedor Plesovsky. Substantial scientific works were written: Svad'ba naroda komi (Komi National Wedding, 1968) by Fedor Plesovsky, Komi epicheskie pesni i ballady (Komi Epic Songs and Ballads, 1969) by Anatoly Mikushev, Detskie pesni i skazki (Songs and Tales for Children, 1969) by Yuri Rochev, and others. During this period, a vast amount of folklore materials was gathered in all regions of the Komi Republic and beyond, previously unknown forms and genres (epic) were found, the then state of Komi folklore was researched, works belonging to the main genres were published, and summarising reviews were written.

The trend gained a new momentum with the publishing of the corpus of the folklore of the nations of the USSR, following the examples of the corpus of Russian folklore (Gorelov 1977). The first step was to publish the three-volume song collection Komi narodnye pesni (Komi Folk Songs, 1966, 1968, 1971) by a group of authors (Anatoly Mikushev, Prometey Chistaliov, Yuri Rochev), and Anatoly Mikushev's monograph Epicheskie formy komi fol'klora (Epic Forms of Komi folklore, 1973). Then, the academic corpus of the verbal cultural heritage of the indigenous population of the Komi Republic was extended and the following collections were compiled and published: Komi poslovitsy i pogovorki (Komi Sayings and Proverbs, 1973), Komi narodnye zagadki (Popular Komi Riddles, 1975), and Komi skazki (Komi Tales, 1976) by Fedor Plesovsky; Komi legendy i predaniia (Komi Legends and Lore, 1984), Komi skazki (Komi Tales, 1991), and Komi starinnye detskie igry (Traditional Komi Children's Games, 1988) by Yuri Rochev, Prometey Chistaliov's monograph titled Komi narodnye muzykal'nye instrumenty (Komi Folk Music Instruments, 1984), and the collection Komi narodnye primety (Komi Folk Portents, 1993) by Vera Kudriashova. The first summarising analysis of Komi folklore, Istoriia komi literatury: Fol'klor (History of Komi Literature: Folklore), was published in 1979. The most significant achievement of Komi folklore studies in this period was Komi narodnyi epos (Komi Folk Epic, 1987) by Anatoly Mikushev, which was published within the series Epos narodov SSSR (Epics of the Peoples of the USSR, 1971-1990).

In preparing the publications, the researches enjoyed vast public attention and support. Field researches of Komi folklore culture were carried out in the territory of the republic and in the areas of concentrated Komi population (Siberia, Murmansk Oblast, Nenets Autonomous Okrug). The fieldwork material required archiving and systematisation to enable research, description, and preparation for issuing publications, and hence, the publishing of folklore 
collections began. There are three archives comprising the main part of the expedition materials collected since 1939. The folklore collections of the Scientific Archive of the Komi Science Centre consist of typewritten and handwritten reports summarising the results of the expeditions starting from 1939.

Since 1957, folklorists have been regularly using tape recorders for their field studies, but as the researchers in all institutes of the Komi subsidiary of the Russian Academy of Sciences focused on forming a united scientific archive (handwritten documents), the collectors held the audio materials in their possession and a recordings library was established only in the late 1970s. In 2000, the recordings library was transformed into the Folklore Archive of the Institute of Language, Literature, and History, and today it is the largest library of traditional Komi culture-related audio and video recordings. The staff maintain, describe, systematise, and restore records of folklore and ethnographic materials. Similar materials are stored in the Folklore Archive of the Syktyvkar State University, where most of the collections were started in the second half of the 1980s. The peculiarity of this archive lies in the geography of the expeditions, as in addition to Komi traditions, the researchers paid special attention to the exploration of the Russian and mixed Komi-Russian areas of the Komi Republic, as well as of the neighbouring territories - Arkhangelsk and Kirov oblasts (Savelyeva 2012).

In the 1990s, Komi folklore studies were freed from the ideological dictate of the Soviet literature studies, which traditionally (and often artificially) had been tied to folklore in Russia since the 1930s. Folklore researchers got the opportunity to explain and interpret folklore facts through ethnography, which inevitably brought folklore studies to the realm of traditional religious beliefs, as studies of the latter belong to ethnography.

On the other hand, in the same period, ethnography was allowed to explore religious and mythological forms of folk life and ethnographers started including folklore facts in their studies. Therefore, the Institute of Language, Literature, and History supported the cooperation in ethnography and folklore studies under the general theme of 'Spiritual Culture of the Peoples in the NorthEast of the European Part of Russia'. Within the framework of the theme, the institute published several collections of scientific articles (including those by folklorists), Pavel Limerov's monograph Mifologiia zagrobnogo mira (Mythology of the Netherworld, 1999) and Oleg Uliashev's monograph Tsvet $v$ predstavleniiakh $i$ fol'klore komi (Colour in the Komi Beliefs and Folklore, 1999), as well as Mifologiia komi (Komi Mythology Encyclopaedia, 1999), which became the first volume of the Encyclopaedia of Urals Mythologies and was translated into English and Estonian.

In 2001, a folklore department was created at the institute. Today, folklorists continue their scientific description, systematisation, and publication of folklore 
materials in fields such as prose fairy tales, ritual folklore, poetry for charms and spells, non-fairy-tale prose, children's folklore, paremiology, and traditional Russian folklore in the Komi Republic. Theoretical and analytical studies explore the genre and poetical peculiarities of folklore texts, the dynamics of folklore genres, and the development of forms in the twentieth and early twenty-first centuries, the local peculiarities of folklore facts, folklore adaptation, mechanisms for the adaptation of folklore texts, and absorption by foreign environments, and the influence of the situation on presenting folklore texts (Krasheninnikova 2016). Information about publications and studies is included in the Bibliographic Index on the website of the Institute of Language, Literature, and History (see Bibliography 2015).

Recently, folklore expeditions have become regular and a comprehensive approach to selecting, collecting, and registering materials has proven useful. The emphasis on collecting the materials that earlier escaped the attention of folklorists allowed filling in the gaps in a number of research fields. The collected materials cover several important topics of modern folklore traditions and genres: calendar rituals, family rituals, religious, children's, and motherhood folklore, folk demonology, poetry for charms and spells, folklore (fairy-tale and non-fairy-tale) prose, etc. Researchers explain the lyrics of ritual and non-ritual poetry, songs, games, and other vocal and musical genres.

The geography of the field research is not limited to the Komi Republic; we also explore Russian and Komi local traditions, areas neighbouring the republic, and other territories of Komi residence (Nenets Autonomous Okrug of the Arkhangelsk Oblast, Yamalo-Nenets Autonomous Okrug, and Khanty-Mansi Autonomous Okrug of the Tyumen Oblast, Komi-Permyak Okrug of Perm Krai, Arkhangelsk and Kirov oblasts) (Krasheninnikova 2015).

This publication is an excerpt of today's Komi folklore studies. The articles present various methodological approaches to the selection and analysis of folklore material as well as the scientific interests of Komi folklore researches. The authors of the articles are leading Komi folklorists, researchers of the folklore and ethnography departments of the Institute of Language, Literature, and History at the Komi Science Centre of the Urals Subsidiary of the Russian Academy of Sciences.

The collection opens with an article by Oleg Uliashev about the ethnic-cultural and ethnic-genetic links between the Komi, Khanty, and Mansi peoples. On the basis of folklore and ethnographic and historical materials, the author suggests that some Khanty groups are formed of Komi, Khanty, and Mansi components.

Pavel Limerov analyses some storylines of Komi legends about the creation of the world. The object of analysis is a contamination of mythological stories of earth-diving and world creation from an egg. The article considers in detail the main components of the stories that have no parallel in similar texts, and offers a hypothesis about the origins of these components. 
Anatoly Panyukov studies the origin and usage of zaum' - a complicated and very peculiar phenomenon. The author analyses one particular example of the Komi charming ritual and offers a hypothesis that linguistic transformations known as zaum' can appear as a result of using the source text in the rhythmic matrix of becharming procedures.

The article by Liudmila Lobanova is dedicated to the verbal component of cattle-breeding rituals. The becharming texts are divided into five types: sentence, ritual dialogue, spell, lamentation, and prayer. A structural and semantic analysis of the most popular sentences gives rise to the definition of two types of texts: close-structure and open-structure sentences.

The article by Aleksey Rassykhaev, an explorer of the Komi play-folklore, is dedicated to a children's game of calling a house spirit (domovoi), which is unique for the traditional Komi culture. Various versions of the game have similar scenarios and the goal of the game is to verify whether the creature exists, and establish contact with it. The author analyses the descriptions of the game and introduces into scientific use new authentic texts and archived materials not used earlier.

Two more articles deal with the Christmas rituals of various local traditions. Galina Savelyeva presents the dynamics of Christmas youth gatherings in the Vishera micro-local tradition. The author describes the different stages of this set of rituals: traditional, Soviet-time teenagers, and today.

The article by Yulia Krasheninnikova and Svetlana Nizovtseva introduces folklore materials collected in the twenty-first century from the Russian population of the mining settlements in the Komi Republic, founded when iron mining started in the area in the middle of the eighteenth century. The folklore traditions originated from the Russian settlers coming from the northern, northeastern, and central provinces of the European part of the Russian Empire. The authors analyse the Christmas rituals and the poetry used by children and adults when visiting neighbours during Christmas.

The final article of the collection by Yulia Krasheninnikova, Head of the Folklore Department of the Institute of Language, Literature, and History, analyses the scenarios of oral historical prose in the same local traditions.

We hope that the goal of this issue of the journal will be achieved and the readers will have a certain understanding of the history and current state of Komi folklore studies, that the articles by the Komi folklorists in the Folklore: Electronic Journal of Folklore will contribute to overcoming the language barrier, and that Komi folklore will be better represented in the world folklore science. We express our gratitude to the authors and reviewers of the articles, to the editorial staff of the journal for the work they did, to the Kindred Peoples' Programme of the Ministry of Education and Research of the Republic of Estonia, and to the Centre of Excellence in Estonian Studies for the financial support. 


\section{NOTES}

1 The overview on this topic is based on the following articles: Mikushev \& Rochev \& Chistaliov 1979; Limerov 2006; Krasheninnikova 2015, 2016.

2 The Komi language belongs to the Permic group of the Finno-Ugric languages together with its close relative Udmurt. It is divided into two main dialect groups: Komi-Zyrian and Komi-Permyak. The name Komi is usually applied to the Komi-Zyrian variety of the language, and to the Komi-Zyrian people. The majority of the Komi people live in the Komi Republic (capital Syktyvkar). The republic is a federal subject of Russia, and it is located in the north-eastern corner of Europe, to the west of the Urals. There are also compact Komi settlements outside the republic: on the Kola Peninsula and in western Siberia. The Komi-Permyaks live south from the Komi Republic, in the former Komi-Permyak Autonomous District (capital Kudymkar) in the Perm Territory. According to the latest census in 2010, there were 228,235 Komi-Zyrians in Russia, and the number of Komi-Permyaks was 94,456.

\section{REFERENCES}

Bibliography 2015 = Bibliograficheskii ukazatel' sektora fol'klora IIaLI Komi NTs UrO RAN (1970-2014 gg.) [Bibliographic Index of the Folklore Department of the ILLH at the Komi Science Centre of the Urals Subsidiary of the RAS (1970-2014).] Syktyvkar: Komi NTs UrO RAN. Available at https://illhkomisc.ru/wp-content/ uploads/2018/10/ukazatel_folkloristy_2007-2014-gg._posl.-var..pdf, last accessed on 10 April 2019.

Filippova, Valentina 2007. Traditsionnaia kul'tura komi v finskikh i vengerskikh izdaniiakh. [Traditional Komi Culture in Finnish and Hungarian Publications.] In: T. Ivanova (ed.) Riabininskie chteniia-2007: Materialy Vnauchnoi konferentsii po izucheniiu narodnoi kul'tury Russkogo Severa. [Ryabinin Readings - 2007: Proceedings of the 5th Scientific Conference for Studying the Popular Culture of the Russian North.] Petrozavodsk: Muzei-zapovednik “Kizhi”, pp. 124-125. Available at http://kizhi.karelia.ru/library/ryabinin-2007, last accessed on 23 April 2019.

Filippova, Valentina 2014. Obriadovaia poeziia komi v zapisiakh XIX veka. [Komi Ritual Poetry Recorded in the 19th Century.] In: V. Filippova. Traditsionnaia kul'tura i fol'klor komi: sbornik trudov. [Traditional Culture and Komi Folklore: Collection of Works.] Syktyvkar: Izdatel'skii dom Komi, pp. 41-46.

Gorelov, Aleksandr 1977. Svod russkogo fol'klora: Prospekt. [Corpus of Russian Folklore: Prospectus.] In: A. Gorelov (chief ed.) Russkii fol'klor: Problemy "Svoda russkogo fol'klora". [Russian Folklore. Problems of the Corpus of Russian Folklore.] Vol. 17. Leningrad: Nauka, pp. 4-10. Available at http://lib2.pushkinskijdom.ru/ Media/Default/PDF/RusFolk/RusFolklore\%20vol.17\%201977.pdf, last accessed on 23 April 2019.

Krasheninnikova, Yulia 2015. Vstupitel'noe slovo k izdaniiu. [Introduction to the Issue.] In: Bibliograficheskii ukazatel' sektora fol'klora IIaLI Komi NTs UrO RAN (19702014 gg.) [Bibliographic Index of the Folklore Department of the ILLH at the Komi SC of the Urals Subsidiary of the RAS (1970-2014).] Syktyvkar: Komi NTs UrO RAN, pp. 2-3. Available at https://illhkomisc.ru/wp-content/uploads/2018/10/ ukazatel_folkloristy_2007-2014-gg._posl.-var..pdf, last accessed on 10 April 2019. 
Krasheninnikova, Yulia 2016. Ot redaktora. [From the Editor.] In: Y. Krasheninnikova (chief ed.) Fol'kloristika Komi. Fol'klornye zhanry Evropeiskogo Severo-Vostoka Rossii: dinamika razvitiia, transformatsii, klassicheskoe nasledie i sovremennye formy. [Komi Folklore. Folklore Genres of the European North-East of Russia: Development Dynamics, Transformation, Classic Heritage, and Modern Forms.] Syktyvkar: Komi NTs UrO RAN, pp. 3-4. Available at https://docplayer. ru/56498129-Folkloristika-komi-folklornye-zhanry-evropeyskogo-severo-vostokarossii-dinamika-razvitiya-transformacii-klassicheskoe-nasledie-i-sovremennyeformy.html, last accessed on 23 April 2019.

Limerov, Pavel 2006. Komi fol'kloristika: Itogi i perspektivy. [Komi Folklore Studies: Results and Perspectives.] In: L. S. Lobanova \& A. N. Rassykhaev (comps.) Bibliograficheskii ukazatel' rabot Instituta iazyka, literatury i istorii Komi Nauchnogo Tsentra UrO RAN (1970-2005). Vypusk 3: Trudy uchonykh otdela fol'klora. [Bibliographic Index of the Institute of Language, Literature, and History at the Komi Science Centre of the Urals Subsidiary of the RAS (1970-2005). Vol. 3: Proceedings of Researchers of the Folklore Department. (Compiled by L. S. Lobanova and A. N. Rassykhaev).] Syktyvkar, pp. 3-8. Available at https:// illhkomisc.ru/wp-content/uploads/2014/11/folk.pdf, last accessed on 23 April 2019.

Lobanova, Liudmila 2017. Proizvedenie V. A. Savina "'Musiur' saiyn” kak istochnik po fol'klornoi traditsii visherskikh komi pervoi treti XX v. ["Musiur saiyn" by V. A. Savin as a Source of Folklore Tradition of Vishera Komi of the First Third of the 20th Century.] In: J. Krasheninnikova (chief ed.) Filologicheskie issledovaniia-2017. Fol'klor, literatura i iazyki narodov evropeiskoi chasti Rossii: formy, modeli, mekhanizmy vzaimodeistviia. [Philological Studies-2017. Folklore, Literature, and Languages of Peoples of the European Part of Russia: Forms, Models, Mechanisms of Interaction.] Syktyvkar: Komi NTs UrO RAN, pp. 51-56.

Mikushev, Anatoly \& Rochev, Juri \& Chistaliov, Prometey 1979. Istoriia sobiraniia i izucheniia komi fol'klora. [The History of Collecting and Studying Komi Folklore.] In: A. Mikushev (chief ed.) Istoriia komi literatury: Fol'klor. [History of Komi Literature: Folklore.] Vol. 1. Syktyvkar: Komi kn. izd-vo, pp. 11-24.

Programme 1924 = Programmy po izucheniiu Komi kraia (Obshchestvo izucheniia Komi kraia). [Programmes for the Exploration of the Komi Region (Society for Exploring the Komi Region).] Ustsysolsk: Komi izd-vo. Available at https://www.prlib. ru/item/361071, last accessed on 23 April 2019.

Savelyeva, Galina 2012. Fol'klornaia traditsiia komi v arkhivnykh fondakh respubliki. [Komi Folklore Tradition in the Archival Records of the Republic.] In: Aktual'nye problemy narodnogo khudozhestvennogo tvorchestva $v$ sovremennoi kul'ture: Materialy mezhregional'noi nauchno-prakticheskoi konferentsii. [Topical Problems of Popular Art in Modern Culture: Proceedings of the Inter-regional Scientific and Practical Conference.] Syktyvkar: GAU RK Tsentr narodnogo tvorchestva i povysheniia kvalifikatsii, pp. 23-32.

Savin, Viktor 1926. "Musiur" saiyn. Viser vozhöd komi iözkostsa s’ylankyv"ias chukörtöm. [Beyond the Watershed: Collection of Komi Popular Songs in Vishera.] Komi mu Zyrianskii krai [Komi Mu - Zyrian Krai] No. 9, pp. 33-41; No. 10, pp. 35-38; No. 11, pp. 35-43.

Startsev, Georgy 1933. Komi fol'klor (ego izuchenie i znachenie, zhanry, detskii fol'klor, kak $i$ chto izuchat'). [Komi Folklore (Its Studies and Significance, Genres, Children's Folklore, What and How to Study).] Syktyvkar: Komi Gosizdat. 


\title{
PERM AND OB-UGRIC RELATIONS IN TERMS OF FOLKLORE DATA
}

\author{
Oleg Uliashev \\ Leading Research Fellow \\ Department of Folklore, Institute of Language, Literature, and History \\ Komi Science Centre of the Russian Academy of Sciences, Russia \\ Email: oulyashev@mail.ru
}

\begin{abstract}
This article examines ethnocultural and ethnogenetic relations between the Komi, Khanty, and Mansi peoples in the recent historical past on the basis of folklore, ethnographic, and historical sources; assumptions are made as to the formation of some of the Khanty groups on the basis of Komi, Khanty, and Mansi components.
\end{abstract}

Keywords: Asyka, ethno-local group, Komi of the Vishera River, mos', Pam, pastar, por, Yaz’va-Komi

\section{INTRODUCTION TO THE PROBLEMATICS}

The Permic and Ob-Ugric languages belong to different branches of the Uralic languages, but at the same time, the Komi and the Ob-Ugric peoples have strong kin and cultural relations that are much closer than those with the peoples of their own language groups (Zherebtsov 1982; Kyzlasov 1984; Napolskikh 1991, 1998; Konovalova 1999; Belavin 2000; Martynova \& Pivneva 2001; Hekel 2001: 54, 59-62; Krachkovsky 2004; Napolskikh 2007, 2008; Kosarev 2008). The disproportion of lexical borrowings reflects the predominant influence of the Komi on the Ob-Ugric peoples, starting from the Late Middle Ages: in the Komi language, there are 25-30 words of Ob-Ugric origin, while in the Ob-Ugric languages, the number of borrowings from the Komi language amounts to 200400 words. In the Ob-Ugric languages, there are even some sacral terms bor-

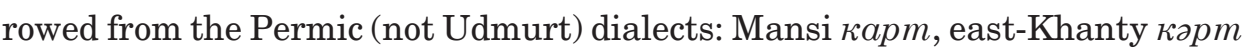
'sacrificial blood' (< pre-Permic гôpd 'blood') or Ob-Ugric Kaлmacb, Kammacb (< pre-Permic * Кьллдьссь-инь 'female deity of child-bearing, fertility, and fate'; *кьлліiсb 'the one who determines fate and gives birth' + *uнb 'mother, wife, woman' > Udm. Му кьллчин 'mother of the Earth', Кьлльссин 'creator') (Shutova 1996: 410-413; 2001; Napolskikh 2008; see also Kosarev 2008), and others. 
The ancient Permiaks and Ugric peoples are also connected by common epic plots that emerged in the 'age of the bogatyrs'1 (Domokos 1980: 313-336), which, in the Ob-Ugric folklore, were incorporated into the context of mythological and epic texts about local and ancestral deities-patrons (dial. mущц, љуццx, юнх; Mansi о̄йка, Khanty икə), while the Komi had their own series of stories about the local bogatyr-sorcerers ( пун; айка). The early Christianization of Perm Vychegodskaya (the fourteenth century) and Great Perm (the sixteenth century) determined the predominantly Orthodox interpretation of the images of tuns 'sorcerer', as opposed to the baptizer Stephen of Perm, in the KomiZyrian folklore, which led to the desacralization of the images of the guardians of places, up to their identification with sorcerers-bandits robbing the vessels that drifted by (Rochev 1984; Rombandeeva 1993: 63, 77; Perevalova 2002: 49; 2004; Limerov 2008: 130-132).

The research of plots and motifs connected with the images of the Ob-Ugric peoples and the Komi described above brings to light the genesis of certain types of folklore texts, allows cultural links and relations between specific multi-ethnic groups to be constructed, and provides a general overview of the migrations of and relations between the peoples of the Cis-Urals, as a result of which individual ethno-local groups were formed.

\section{PARALLEL PLOTS AND CHARACTERS-MEDIATORS OF PERMIANS AND THE OB-UGRIC PEOPLES}

In terms of folklore and genetic comparisons, the legends of the Komi-Zyrian Йиркаn, Mansi Па̄ст о̄йка, and Khanty Пастэр ики are of particular interest. In those legends, the characters were chasing a blue doe (or a white elk cow), running to the Urals and back on their miracle skis so fast that the freshly baked bread they were keeping in their bosom did not even get cold. The preUral myth about the bogatyr (a bear) having a cosmic hunt on a doe (an elk cow) was considered as a mythological justification for exogamous marriages between representatives of the two phratries, in the context of which the plot of the Komi-Permiak legend about pam (leader) Kudym Osh getting married to Kostö, the daughter of the Vogul prince Asyka, also unfolds (Limerov 2008: 132-134).

The northern Mansis and the northern Khanty date some of their surnames to the mythical ancestor Pastər iki (Пащар-икə, Пастьр ойка, Па̄ст о̄йка), to whom they link the migration of the Ob-Ugric peoples. Researchers have drawn parallels between the mythical people namар ёx, лоньщ-ар ёx, literally 'the people of Pechory, the people of songs and fairy tales', which were living 
at Paschar as 'the Pechora River' (As 'the Great River', 'the Ob River'), and the people of the Mansi, who migrated from the European side of the Urals to the Central Siberian Cis-Urals and later into the lower reaches of the Ob River, where the Mansis built Paschera yurts (Khanty Пастэр курm, Mansi Паuтор юрm) and mixed with the Khanty (Rombandeeva 1993: 42-44). In the tradition of the northern Khanty, on the last day of the Bear Feast, ${ }^{2}$ the spirit of the bear 'is taken away behind the Stone ${ }^{3}$ by the seven men- paschar to the Paschar River, which is like the white-water Ob' (Uliashev 2011: 55). The origins of the Pastorovs Khanty that lived in Paschera yurts and Aspukhol yurts are linked to 'the winged and the big-foot' bogatyr that came from the upper reaches of the $\mathrm{Ob}$. The fact that the Khanty from the lower reaches of the Ob River referred to them as vadasi 'the dumb' and lev ohal' 'Sosva Voguls' is also indicative of the different ethnic origins of this family line. In addition to the Pastorovs, the Khanty from the lower reaches of the Ob River also recognize the Shuganovs, the Ilyins, and the Kormyakovs, who honour Pastor iki or Hyn' iki, among the family line of Pastor yoh (Perevalova 2002: 48-49) and, as judged by variable identification of Pastor iki with the master of the lower world, as belonging to the por phratry.

According to the materials collected by Aleksandr Dunin-Gorkavich and Valery Chernetsov (Dunin-Gorkavich 1911; Chernetsov 1939: 25-26), the bogatyr ancestors of this family line, i.e., the Mansis, rode elks, while their descendants, the Sampil'talovs, who had migrated from the western Cis-Urals (the basins of the Lozva and Vogulka rivers) and settled at the estuary of the Leplya River at the mouth of the Sosva River, honoured Лen-mum-oǔкa embodied by a silver elk with golden eyes. The cult of the elk has also been preserved among the Khanty within the family line Ac-пухлын-ёx 'people from the settlement at the Ob River' (the Yeleskins, the Konkins, the Taragupa, the Kostins, and the Pas'marovs), originating from the Yelesins, who had inhabited the banks of the Lozva River, and who are referred to in different sources both as the Mansis and the Khanty. Their family deities include Xорал ур нә 'a beautiful forest woman' or Мис нә 'a cow-girl', embodied by an elk cow (Perevalova 2002: 51). This female representative of the forest spirits (лис-ёx) has a bright look (Kulemzin \& Lukina 1973), and her clothes are green, red, and yellow, which is typical of the patrons of the mos' phratry (Gemuev 1990: 67-68). A man that $M и с$ нэ has sex with becomes lucky and rich, ${ }^{4}$ but when she is visiting the house, there must not be any other women inside because otherwise she will be offended (Gondatti 1888: 8, 34).

The existence of the invariable pair of patrons in the shape of a 'bear' (por) and an 'elk cow' (mos') among the people of pastor is indicative of the fact that the migration to the lower reaches of the Ob River from the Northern Sosva and 
Lyapin rivers was longstanding, and it took place not only among individual migrants or their families, but by very mature groups of the Khanty, which had a very strong Mansi component in their midst. Judging by the cessation of marriages between the Mansis and the Khanty living in the basin of the Sosva and the Lyapin rivers by the seventeenth century (Sokolova 1979: 120, 123; Perevalova 2002: 51-52), the formation of the independent group finished at the end of the sixteenth century, when pastor yoh became 'the Ostyaks' for the Mansis and 'the Voguls' for the Khanty. Such an exoidentification and folklore and historical data about 'the former homeland' allow us to assume that the origins of the pastor yoh are not only Ugric.

In this respect, the legends of the Komi-Permiaks about the marriage of the Chud пан (pan; gentleman) Kudym Osh to a daughter of the Vogul prince Asyka are interesting. This event is associated with the 'golden age' of the ancestors of the Permiaks ('the bogatyr Chud') subordinate to supreme leaders (пан 'pan; gentleman'), one of which was Kudym Osh (< Komi-Permiac Ku dyn Osh 'a bear from the Ku River'), born by the priestess of the deity Voipel' or Siura-pelia 'big-horned and big-eared'. 'The mother of Kudym-Osh named Potös' ( $<$ ?? Komi potny 'to crack, to burst') or Pövsin 'one-eyed' was so ugly that she could not seduce any single man, which is why she gave birth to a child from a bear (Klimov 1964; Ozhegova 1971: 15, 28, 29, 32; 1972). The worshipping of the Permians of Voipel' the dumbhead is mentioned in historical documents (see Manuscript 1958: 257-271, and others). According to folklore materials, the Komi regarded him as the night guardian of people, the deity of the Moon, night, and the northern wind, and the patron of warriors (Nalimov 1903: 120-124; Ozhegova 1972; Uliashev 1999; Limerov 2008: 130-132). Voipel' sends a storm on his enemies, while Kudym Osh, who had released beaten enemies, is sent by the priestess 'to smear the sacrificial animal with blood' (Peliut-iz literally 'Peli's stone') to redeem himself (Ozhegova 1972: 11-12).

Khanty Em-vosh iki, Mansi Yalp-us oika 'sacred city' (Komi Vezhakory (vezha 'sacred' + kar 'city'), Khanty Emyng vosh, Mansi Yalpyng us 'a man' who lives at the confluence of the Gornaya, Malaya, and Togotskaya Ob, walks in the shape of a bear, has seven bear-like horses and is wearing a fur coat with bear claws. The northern Khanty honour him under the name of Tyl'sch un sempa hon 'the tsar with eyes as large as the Moon'. In the perceptions of the Kazym Khanty, he appears in the shape of a fiery-red bear, rides a black horse, and is sacrificed in a black robe. According to them, he brought the bow and fire to people, and his tasks are to help sick people, keep souls in the Middle World, and assist the midwife-Kaltasch (Karapetova \& Soloveva 2000: 203, 204). In myths, he fights in the lower world to save his wife, but he is only able to do that with the help of his younger brother (Khanty Mir vantty he, Mansi Mir susne 
hum 'a man observing the world'), a horseman on the bright horse (Startsev 1928; Kashlatova 2002: 57; Uspenskaia 2002: 39-45). Izmail Gemuev comes to the conclusion that the 'heaven horseman' (Mir susne hum) put the 'horseman on the bear' (Yalp-us-oika), the deity of the ancient Ural taiga settlement (Yalp-us-oika), on the back burner, but inside their phratries they fulfil similar functions of protecting people and maintaining morality (Gemuev 1990: 75, 86, 138, 220, 221; also see Bogordaeva 2004: 91-93).

The Komi Voipel' and 'the bear from the Ku River' are very close to the Khanty Em-vosh iki and Mansi Yalp-us oika in terms of their properties and functions (at least, typologically). Voipel' - the Moon - is the night guardian that gives (and takes away) children and sends stormy weather for the violation of social norms. Kudym Osh wears a beaver or sable fur coat both in winter and in summer and proves to be a person with a civilising mission, bringing iron, cereal, etc., to the Chud people; he sails to the Voguls in a black boat made from a black elm tree (yrzha pu) that is rare in the territories of Perm Krai, which is highlighted in the text (Ozhegova 1972: 11-12). In spite of the fact that the Komi did not have a phratry system (at least, at the time when historical records were made), the marriage proposal of the 'bear-prince' to a bride having an elk or a calf face is clearly based on the idea of the social order consisting of two parts. Kudym Osh has 'bear origins', while the awareness of the mother of the Vogul bride points out some kind of connection between her and the people of the Asyka prince.

The cunning Potös' spread rumours about the beautiful daughter of the Vogul prince who lives near the high mountains in the upper reaches of the Yazva River. She will bear a bogatyr child to the man who will marry her, which is her destiny. And Potös' was doing her best in order that the rumour would reach Kudym Osh, saying that she had heard that herself from the people who were coming to the sanctuary. But the cunning Potös' was lying: she knew that the daughter of the Vogul prince was a monster with an elk head and that many men were trying to court her, but none of them came back. The Vogul prince did not want the ill fame about his daughter to spread and killed all of the men who refused to marry her after they had seen her face. (Klimov 1964: 12)

In the Komi-Zyrian legends about the hunter Yirkap (Irkab) a sorceress who wanted to get rid of the hero turned her daughter into a blue doe, who turned into a magpie near the Sibyr-iz 'Siberia stone', and then into a beautiful girl who asked the hero to marry her, but the bogatyr killed the girl and took the heart of the doe-girl to her mother (Rochev 1984). The Permian and the southern Zyrian son of a bear Pelia (Peria, Pera) was chasing the wood spirit Vöris' kul' 
(Vörsa) up to the Ural stone, then killed him and married his wife. The motif of a sorceress (options: a mother, a stepmother, a sister) sending the hero to death is not only common in epic legends with the plot of chasing a doe / an elk cow, but is also widespread in fairy-tale folklore.

The wild origins of the spouse of the main character are in accord with the nuptial-ritual idea of the magical uncleanliness of the bride being a girl of an alien family line. The ritual beating of the bride with a withe or a lash occurs both in the Komi and in the Ob-Ugric folklore. In the Komi folklore the bride is beaten with an alder withe by some old male assistant, and only after creeping things leave her body does he hand her over to the groom. In Ob-Ugric folklore, Em-vosh iki / Yalp-us oika 'purifies' the wife of As tyi iki / Oias oika ('a man from the upper reaches of the Ob'). In the Permian text, the secret of the ugly mask of the bride, which marks her as belonging to an alien family line, is disclosed to Kudym Osh by a Vogul woman Vayasi, whose name, without any

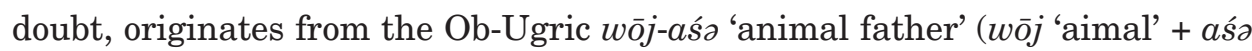
'father'), i.e., the parent and protector of animals.

In the folklore of the Ob-Ugric peoples, the wife of the master of the sacred city is procured by brothers from the lower world, a hostile country lying behind the Stone. In Komi folklore, the image of the Stone Mountains is also quite traditional, being the border between the family line of the main character and the family line of the bride, or as a place where her family line lives. Hence, Komi and Ob-Ugric folklore materials mutually duplicate each other, which allows an assumption to be made about the existence of marital relations, at least between the epic ancestors of the Komi and the Mansis.

\section{DESIGNATION OF THE KOMI PEOPLE (SARAN YOKH) FROM POR TO MOS'}

Modern Ob-Ugric peoples are quite consistent in assigning the Zyrians (saran) to mos'. In the texts about the marriage of the bear-bogatyr to the elk cow-princess, the Voguls are clearly designated as mos', while the ancestors of the Permiaks (the bogatyr Chud) are designated as por. Consequently, it would be logical to assume that nuptial alliances were made between some Komi-Permiak and Ob-Ugric groups which had some kind of phratrial order. Taking into consideration the connection between the Christianization and the overgrowth of birches that is consistent in the folklore of the peoples of the north of Russia, as well as the fact that it is the golden birch that is the attribute of the Kaltas' and the Heaven Horseman, the guardians of the mos', the perceptions of the Komi of the por people can refer to the period of non-Christianized Permians living in the 
contact area. Folklore identification of the eastern Permians, representatives of the 'bear phratry', is indicative of the historical existence of the group of the Komi isolated from the Dvina-Vym-Vychegda (Perm Vychegodskaya), Luza (Small Perm), and Kama (Great Perm) Komi, which was peripherally integrated into the Ugric cultural area that covers the left bank of the Kama River and the upper reaches of the Vychegda, Pechora, and Ob rivers, the hydronyms of which contain the duplication of the names of tributaries that cannot be attributed to anything else but for the fact mentioned above: the rivers Vishera, Kosyu, Mylva, Sosva, etc. The descendants of this group are apparently the Cherdyn or Yazva Komi, whose language (even in terms of phonetics) is very different from the Zyrian and Permian dialects. Besides, the eastern 'Permiaks' are anthropologically closer to the Ural type, which has been preserved among the modern Mansis to the fullest extent possible.

The material that serves as a basis for making assumptions about the phratrial-nuptial relations between the Permians and the Ob-Ugric peoples in the Middle Ages provides the image of the Vogul prince Asyka, who combines the features of a mythological deity, an epic character, and a real historical figure. According to the legend, Asyka lives in the upper reaches of the Yazva River, which is a tributary of the Kama River. In accordance with the historical documents, the Pelym prince Asyka, together with the Permians and the people living on the banks of the Vyatka River, takes part in numerous incursions: in Perm (in 1455, when Bishop Pitirim of Perm was killed), Cherdyn (in 1481), etc. (Manuscript 1958: 261). In folklore and historical texts he is referred to as 'the Vogul prince', but his name is clearly of Khanty origin: 'Ob man, Ob master' < Khanty $A s$ 'Ob' + iki 'a man'. ${ }^{6}$ In the Mansi vocalization, his name would sound like Orc ōŭka. It is obvious that this name was not so much a proper name as indicative of territorial belonging and a high status, related to mythological succession from the seventh son of Thorum and Kaltas' (heavenly god and fertility goddess) - Khanty As tyi iki 'a man from the upper reaches of the Ob' (>As iki).

The mythical master of the upper reaches of the Ob River, who has many names (Khanty Sanke 'Light', Ort 'Guardian' > 'Prince', Loven ho 'horseman', Mansi Luvsan hum 'horseman', Khanty Muv vertty he 'a man walking around the world', Mir vantty hu 'a man protecting the world' and Mansi Mir susne hum 'a man protecting the world'), and keeps watch over the order in the world of people (Bogordaeva 2004: 187; Baulo 2007: 71-73). 'The heaven horseman' patronizes the mos' phratria. He is depicted as riding a white or a golden mare with eight wings, and more rarely as riding an elk cow. On the whole, the marriage of Kudym Osh to the daughter of As iki is quite logical in terms of mythology.

The image of Pan-sotnik, included in the Komi folklore series about Stephen of Perm as Pan, Pam, or Pama ${ }^{7}$ and preserved in fairy tales as a situational 
character who has the sacral knife pan purt, sparks as much interest. According to some texts, Pam was unable to oppose Christianization and colonization by Moscow, and he left for Siberia.

And Pam said to the people: "One night and one day bury all of your belongings, your ornaments, and your jewellery so that foreigners will not find anything." And Pam also said: "Do not touch the sleazy one, let him live among us without knowing us, let him walk among us without seeing us, let him talk to us without hearing us. Do not touch him, because if you kill him, many more of the ones like him will follow." In one night and one day the people hid all of their riches, jewellery and ornaments, and buried them to wait for better days. And they left the Orts to guard their treasures. The time will come when the treasures come out by themselves. And Stephan did not find anything. He came to an empty place.

The peoples were the манси, мансі, and манса. The манси and мансі, they are like the Komi. And let us not talk about the манса at all, especially before the night falls. They were horrible people, inhuman. The say Pam left together with the Mansis when Christianity entrenched itself in the Komi Land. He was living somewhere beyond the Urals. And he is buried in Siberia. ${ }^{8}$

The historical Pan-sotnik, who fulfilled the functions of a spiritual and a military leader among the Permiaks, made incursions on Ust-Vym (1380, 1384), Yarensk (1389), etc., almost one hundred years earlier than the historical Asyka. According to the Vym-Vychegda manuscript (Manuscript 1958: 260), in 1384, Pan was 'expelled from the territories of Perm from his kin and tribe' to Udora and Pinega, and in 1392, he laid siege to Ust-Vym with the Voguls. At the end of the fourteenth century, Pan-sotnik was forced to leave, taking with him 'a large share of the Permiaks and the Zyrians, who had lived in Great Perm and left their spacious lands on the western side of the Ural Mountains. He persuaded them to move to the harsh northern lands near the Ob River, to the lands where they are not different from the Kondyrs now, but are referred to as the Ostyaks alongside with them' (Georgi 1776: 66). At first, the migrants settled in the area of Bol'shoi Altym, from which thirty people fled from being christened by Metropolitan Philotheus Leschinsky behind Obdorsk, into the Vokhsarkovs yurts (today the village of Aksarka) (Georgi 1776: 67).

In the manuscript of 1380 (250-300 years before the emergence at the upper Vychegda of settlements with the Orthodox Komi population) it is mentioned that Pan lived at the right tributary of the Vychegda River in 'a place named Vishera' (Manuscript 1958: 258). Being a strategically important junction point that connects the upper reaches and the tributaries of the Vym, Vychegda, Izhma, Pechora (extending out behind the Urals through the Ilych River), and 
Kama rivers (extending out behind the Urals through the Yazva River), the area of Vishera on the banks of the Vychegda River was the area of co-existence of the Komi and the Mansis. ${ }^{5}$ The specific cultural features of the Vishera local group of the Komi-Zyrians living in the upper reaches of the Vychegda River have been preserved until now. The Vishera Komi are distinguished by the phenomenon that among them we can meet the carriers of Ural anthropological features (dark hair and irises, stockiness, eye shape) more often, which gives a reason for other peoples living in the upper reaches of the Vychegda River to jokingly call their neighbours visersa iaranyas 'the Vishera Nenets' and s'öd vogil'yas 'the Black Mansis'.

The references to Pan-sotnik living simultaneously at the Vychegda River and in Great Perm, his power over the Permiaks and the Zyrians and, at the same time, his incursions on the towns near Great Perm and at the banks of the Vychegda River together with the Voguls allow us to make a number of assumptions. Firstly, the influence of Pan spread through the entire pre-Christian population inhabiting the territories between the Kama and the Vychegda Visheras (Komi Viser). Secondly, this Perm population interacted with the Voguls much more than with western and south-western Permians. Thirdly, a considerable part of the Vishera Permians was forced to move beyond the Urals together with the Voguls, under the pressure of Christian migrants (the inhabitants of the banks of the Vychegda, Dvina, and Vym rivers, the northern Russians).

The remaining 'Visheras' mixed with the western Komi, who were related to them in terms of language, and made the nucleus of the local eastern subgroups of the Komi-Zyrians and the Komi-Permiaks. In the fifteenth through seventeenth centuries, the 'Visheras' who had moved to Siberia with Pan-sotnik, took part in the formation of the mixed group (the Mansis + the Khanty + the Komi), on the basis of which a separate subgroup of the northern Khanty was formed. Most probably it was also the reason for the abundance of 'Permisms' in the modern Ob-Ugric languages, except for the borrowings of later periods. The last tribute to the language of the ancestral home was, apparently, the name Kama that was given to a small tributary of the Konda River.

\section{CONCLUSIONS AND PERSPECTIVES}

In general, the comparative research of Permian and Ob-Ugric folklore, when compared with historical documents, gives a fairly clear idea that the ObUgrians (apart from the Voguls-Mansis mentioned in the chronicles) did not constitute a monolithic ethnos in historical terms. This is also reflected by cultural and language differences between the northern and southern Mansis, 
between the northern, eastern, and southern (assimilated to date) Khanty. It is enough to note a strong divergence between the territorial Khanty parlances, very loosely referred to as 'dialects'.

If we can speak of the modern Mansis as direct descendants of the Voguls, then the direct identification of the chronicle's Yugra or even the Ostyaks with the ancestors of the modern Khanty, which is popular today, is a long stretch, since those generic names united many Samoyedic and Ugrian clans, being more geographical rather than ethnonymic terms. Representatives of very diverse peoples were involved in the formation of the modern Khanty, as evidenced by the names of individual clans: Ur Sirn ('Nenets clan'), Saran Sirn ('Zyrian clan'), Pastar Yokh ('Pashcher/Pechora (?) people', Lev Okhal ('Sosva Voguls'), etc.

There is no doubt that representatives of the Komi people also took part in the formation of the modern Mansis and (at least, the northern) Khanty, although to varying degrees, as evidenced by a wide linguistic, folkloric, and historical material. Nevertheless, the question of the ethnic components and the ethnogenesis of the Ob-Ugrians remains open, which provides ample opportunities for future research.

\section{NOTES}

1 The 'heroic era' of the peoples under consideration is aligned with the Christianization of the Komi; the colonization of the Cis-Urals and Trans-Urals; Permian and Vogul invasions into small towns on the banks of the Kama, Vychegda, and Dvina rivers; the military campaigns of the Kurbsky princes 'from the rivers Vym, Vychegda, Sysola, Dvina' against the princes of Yugorsk in 1483, 1499-1500, etc. The texts about bogatyrelders (Komi айкa, Khanty ики, ойка, Mansi о̆йка) date back to the thirteenth-sixteenth centuries (Beliaev 1852: 1-264; Rogov 1858; Tizengauzen 1884; Bakhrushin 1935; Zbrueva 1952; Manuscript 1958: 257-271; Novoseltsev 1965: 410-417; Levitsky 1978; Zherebtsov 1982; Sukhoguzov 1989: 160-163; Belikova 1996).

2 A traditional complex of rituals dedicated to the bear.

3 The Urals.

4 The texts about the cohabitation of a hunter with a forest woman who brings luck in hunting and fishing are widespread among the Komi-Zyrians.

5 An expanded linguistic-toponymical analysis and the textological analysis of the plots about the Komi-Permiak gentlemen-bogatyrs Ku dyn Osh, Pera, and Kupra (?? < Ku $+P(e) r a$ 'Pera from the Ku River') could also lead to certain conclusions.

6 The Komi origins of this word can also be assumed as an ill-conditioned and virtually impossible hypothesis: Komi asyka 'belted, iron-sided' < asyk 'rim', 'girdle', 'ironwork'. The reason for that is the names of the younger Kondsky princes that are mentioned in the manuscript and are admittedly of the Komi origin: Changyl' 'upturned, cocked задранный кверху (about a nose, a shoe toe)', Lyab 'weak, sickly' (Manuscript 1958: 262). 
7 The plots about the confrontation and theological discussions of Stephen and Pan-sotnik are quite well analysed in the work of Pavel Limerov (2008); see also Druzhinin 1897.

8 Recorded by O. Uliashev in Syktyvkar in 1998 from Y. S. Kushmanov, born in the village of Chuhlom of Syktyvdinsky District of the Komi Republic in 1947 (field data collected by the author).

9 After the incursions, the Permians and the Voguls would most often leave upstream the Vychegda River, while after the incursion on Cherdyn, the captive Perm bishop Pitirim was killed at the Pomos River, at the right tributary of the Vychegda River.

\section{REFERENCES}

Bakhrushin, Sergey 1935. Ostiatskie i vogul'skie kniazhestva v XVI-XVII vv. [Ostyak and Vogul Principalities in the 16th-17th Centuries.] Leningrad: Izd-vo Instituta narodov severa TsIK SSSR im. P. G. Smidovicha.

Baulo, Arkady 2007. Kollektsiia kul'tovoi atributiki hantov iz posiolka Tegi. [Collection of Cult Attributes of Khanty from Tegi Settlement.] In: A. Baulo (ed.) Pamiati I. N. Gemueva: Sbornik nauchnykh statei i vospominanii. Novosibirsk: Izdatel'stvo Instituta arheologii i etnografii SO RAN, pp. 71-76.

Belavin, Andrey 2000. Kamskii torgovyi put': Srednevekovoe Predural'e v ego ekonomicheskikh $i$ etnokul'turnykh sviazyakh. [Kama Trade Route: The Medieval CisUrals in Economic and Ethno-cultural Connections.] Perm: Permskii gosudarstvennyi pedagogicheskii universitet.

Beliaev, Ivan 1852. Geograficheskie svedeniia o Drevnei Rossii. [Geographical Data on Ancient Russia.] Zapiski Imperatorskogo Russkogo geograficheskogo obshchestva, Vol. 6, pp. 1-264.

Belikova, Olga 1996. Srednee Prichulym'e v X-XIII vv. [The Region of Middle-Chulym in the 10th-13th Centuries.] Tomsk: Izdatel'stvo Tomskogo universiteta.

Bogordaeva, Aksana 2004. Signifikativnye funktsii odezhdy v traditsionnoi obriadnosti obskikh ugrov. [Significative Functions of Clothes in Traditional Ceremonialism of the Ob-Ugrians.] Vestnik arkheologii, antropologii i etnografii, Vol. 4, pp. 184-192. Available at http://ipdn.ru/_private/a4/3-bog.pdf, last accessed on 6 May 2019.

Chernetsov, Valery 1939. Fratrial'noe ustroistvo obsko-ugorskogo obshchestva. [Phratrial Structure of the Ob-Ugric Society.] Sovetskaia etnografiia, Vol. 2, pp. 20-42.

Domokos, Péter 1980. La poesie populaire des peuples finno-ougriens. In: Péter Hajdú (ed.) Le peuples ouraliens: Leur culture, leurs traditions. Budapest: Corvina, pp. 313-336.

Druzhinin, V. G. (ed.) Epifanii Premudryi 1897. Zhitie sv. Stefana, episkopa Permskogo, napisannoe Epifaniem Premudrym. Zhitie sviatogo Stefana episkopa permskogo. [Life of Saint Stefan Bishop of Perm, Written by Epiphany Premudry.] St. Petersburg: Izd. Arkheograficheskoi komissii.

Dunin-Gorkavich, Aleksandr 1911. Tobol'skii Sever. [Tobolsk North.] Vol. 3. Tobolsk: Gubernskaia tipografiia.

Gemuev, Izmail 1990. Mirovozzrenie mansi: Dom i kosmos. [Mansi Worldview: Home and Space.] Novosibirsk: Nauka. 
Georgi, Iogann Gottlib 1776. Opisanie vsekh v Rossiiskom gosudarstve obitaiushchikh narodov. [Description of All Peoples Living in the Russian State.] Part 1. St. Petersburg: Tip. I.K. Shnora.

Gondatti, Nikolai 1888. Sledy iazychestva inorodtsev severo-zapadnoi Sibiri. [Traces of Paganism of Indigenous Dwellers of Northwest Siberia.] Moscow: Tip. E. G. Potapova.

Hekel, Iozef 2001. Pochitanie dukhov i dual'naia sistema u ugrov (K probleme evraziiskogo totemizma). [Honouring of Spirits and Dual System among Ugrians (To the Problem of the Eurasian Totemizm).] Translation from German by N. V. Lukina. Tomsk: Izdatel'stvo Tomskogo universiteta.

Karapetova, Irina \& Soloveva, Kseniia 2000. Obraz khoziaina Iugana "Iavun-iki" kak simvol kul'tury iuganskikh khantov. [Image of the Host of Yugan "Yavun-iki" as a Symbol of the Culture of Yugan Khanty.] In: Etnografiia narodov Zapadnoi Sibiri: Kiubileiu doktora istoricheskikh nauk, professora Z. P. Sokolovoi. Sibirskii etnograficheskii sbornik, Vol. 10, pp. 200-209.

Kashlatova, Liubov 2002. Funktsii dukha Em-vosh-iki. [Functions of the Spirit Em-voshiki.] In: T. A. Moldanova \& A. D. Kaksin (eds.) Materialy V iugorskikh chtenii: Medved'v kul'ture obsko-ugorskikh narodov. Khanty-Mansiisk, 22 maia $2002 \mathrm{~g}$. Khanty-Mansiysk: Poligrafist, pp. 56-59.

Klimov, Vasily 1964. Kudyn-Osh, chudskoi pam. [Kudyn-Osh, Chud Pam.] In: M. D. Vavilin \& V. V. Klimov (eds.) In'va: literaturno-khudozhestvennyi sbornik. Kudymkar: Permskoe knizhnoe izdatel'stvo, pp. 55-66.

Konovalova, Irina 1999. Vostochnaia Evropa v sochinenii al-Idrisi. [Eastern Europe in al-Idrisi's Work.] Moscow: Vostochnaia literatura.

Kosarev, Mikhail 2008. Osnovy iazycheskogo miroponimaniia: Po sibirskim arkheologoetnograficheskim materialam. [Fundamentals of the Pagan Worldview: On the Siberian Archaeological-Ethnographic Materials.] Moscow: Slava.

Krachkovsky, Ignaty 2004. Arabskaia geograficheskaia literatura. [Arab Geographical Literature.] Moscow: Vostochnaia literatura.

Kulemzin, Vladislav \& Lukina, Nadezhda (comps.) 1973. Legendy i skazki khantov. [Khanty Legends and Fairy Tales.] Tomsk: Izdanie Tomskogo universiteta.

Kyzlasov, Leonid 1984. Istoriia Iuzhnoi Sibiri v srednie veka. [History of Southern Siberia in the Middle Ages.] Moscow: Vysshaia shkola.

Levitsky, Timofey 1978. "Mad'iary" u srednevekovykh arabskikh i persidskikh geografov. ["Magyars" in the Works of Medieval Arab and Persian Geographers.] In: Vostochnaia Evropa $v$ drevnosti $i$ srednevekov'e. [Eastern Europe in the Ancient Time and Middle Ages.] Collection of articles. Moscow: Nauka, pp. 56-60.

Limerov, Pavel 2008. Obraz sv. Stefana Permskogo v pis'mennoi traditsii i v fol'klore naroda komi. [St. Stephen of Perm's Image in Written Tradition and Folklore of the Komi People.] Moscow: Nauka.

Manuscript 1958 = Vychegodsko-Vymskaia (Misailo-Evtikhievskaia) letopis'. [Vym'Vychegda (Misail-Eutyches') Chronicle.] Istoriko-filologicheskii sbornik Komi filiala AN SSSR, Vol. 4, pp. 257-271. Available at http://yakov.works/acts/17/1/ vychegod.htm, last accessed on 23 May 2019.

Martynova, Elena \& Pivneva, Elena 2001. Traditsionnoe prirodopol'zovanie narodov severnogo Priob’ia (Po materialam Khanty-Mansiiskogo avtonomnogo okruga). 
[Traditional Use of Natural Resources among the Peoples of the Northern Ob (On Materials of the Khanty-Mansi Autonomous Okrug).] Moscow: In-t etnologii i antropologii RAN.

Nalimov, Vasily 1903. Zyrianskaia legenda o pame Shypicha. [Zyrian Legend about Pama Shypicha.] Etnograficheskoe obozrenie, No. 2, pp. 120-124. Available at https://archive.org/details/eo_LVII_1903/page/n127, last accessed on 7 May 2019.

Napolskikh, Vladimir 1991. Drevneishie etapy proiskhozhdeniia narodov ural'skoi iazykovoi sem'i: dannye mifologicheskoi rekonstruktsii (praural'skii kosmogonicheskii mif). [Ancient Stages of the Origin of the Peoples of the Uralic Language Family: Data of the Mythological Reconstruction (the Proto-Uralic Cosmogonic Myth).] (Materialy k serii “Narody Sovetskogo Soiuza”. Vyp. 5: Narody ural'skoi iazykovoi sem’i). Moscow: Institut etnologii i antropologii im. N. N. Miklukho-Maklaia.

Napolskikh, Vladimir 1998. O proiskhozhdenii nazvaniia Iugra. [About the Origin of the Name Yugra.] In: I. Gemuev (ed.) Sibir'v panorame tysiacheletii (Materialy mezhdunarodnogo simpoziuma), Vol. 2. Novosibirsk: IAET SO RAN, pp. 343-351.

Napolskikh, Vladimir 2007. Permsko-ugorskie vzaimootnosheniia po dannym iazyka i problema granits ugorskogo uchastiia v etnicheskoi istorii Predural'ia. [PermUgrian Relationship According to Linguistic Data and the Problem of Borders of Ugrian Participation in the Ethnic History of the Cis-Urals.] XVII Ural'skoe arkheologicheskoe soveshchanie: Materialy nauchnoi konferentsii. Ekaterinburg \& Surgut: Magellan, pp. 41-43.

Napolskikh, Vladimir 2008. Permsko-ugorskie vzaimootnosheniia po dannym iazyka i problema granits ugorskogo uchastiia v etnicheskoi istorii Predural'ia. [PermUgrian Relationship according to Linguistic Data and the Problem of Borders of Ugrian Participation in the Ethnic History of the Cis-Urals.] Voprosy arkheologii Urala, Vol. 25, pp. 14-25.

Novoseltsev, Anatoly 1965. Vostochnye istochniki o vostochnykh slavianakh i Rusi VI-IX vv. [Eastern Sources about the Eastern Slavs and Russia in the 6th-9th Centuries.] In: V. Pashuto \& L. Cherepnin (eds.) Drevnerusskoe gosudarstvo $i$ ego mezhdunarodnoe znachenie. Moscow: Nauka, pp. 410-417. Available at https://azbyka.ru/otechnik/Istorija_Tserkvi/drevnerusskoe-gosudarstvo-i-egomezhdunarodnoe-znachenie/2_1, last accessed on 7 May 2019.

Ozhegova, Mariia 1971. Komi-permiatskie predaniia o Kudym-Oshe i Pere-bogatyre. [Komi-Permyak Legends about Kudym-Osh and the Bogatyr Pera.] Perm: Permskii gos. pedagog. in-t.

Ozhegova, Maria 1972. Istoricheskie osnovy komi-permiatskogo predaniia o "KudymOshe”. [Historical Bases of the Komi-Permyak Legend about Kudym-Osh.] In: Problemy izucheniia finno-ugorskogo fol'klora. Saransk: Mordovskoe knizhnoe izd-vo, pp. 63-73.

Perevalova, Elena 2002. Voiny i migratsii severnykh khantov (Po materialam fol'klora).

[Wars and Migrations of the Northern Khanty (On Folklore Materials).] In: V. Alekseev (chief ed.) Drevnie i srednevekovye kul'tury Urala $v$ evraziiskom kul'turnom prostranstve. Ural'skii istoricheskii vestnik No. 8. Ekaterinburg: Akademkniga, pp. 36-58. Available at http://www.ihist.uran.ru/files/uiv8.pdf, last accessed on 7 May 2019.

Perevalova, Elena 2004. Severnye khanty: Etnicheskaia istoriia. [Northern Khanty: Ethnic History.] Ekaterinburg: UrO RAN. 
Rochev, Yuri (comp.) 1984. Komi legendy i predaniia. [Komi Legends and Folktales.] Syktyvkar: Komi knizhnoe izd-vo.

Rogov, Nikolay 1858. Materialy dlia opisaniia byta permiakov. [Materials for the Description of the Life of the Permyaks.] Zhurnal Ministerstva vnutrennikh del, Vol. 29, No. 4, pp. 45-126.

Rombandeeva, Evdokiia 1993. Istoriia naroda mansi (vogulov) $i$ ego dukhovnaia kul'tura (po dannym fol'klora i obriadov). [History of the Mansis (Voguls) and Their Spiritual Culture (According to Folklore and Ceremonies).] Surgut: AIIK Severnyi dom.

Shutova, Nadezhda 1996. Obraz drevneudmurtskogo zhenskogo bozhestva: vozmozhnosti ego rekonstruktsii. [Image of the Old Udmurt Female Deity: Possibilities of Its Reconstruction]. In: Congressus Octavus Internationalis Fenno-Ugristarum. Jyväskylä 10-15.8.1995. Pars VI. Ethnologia and Folkloristica, pp. 410-413.

Shutova, Nadezhda 2001. Dokhristianskie kul'tovye pamiatniki v udmurtskoi religioznoi traditsii. [Pre-Christian Cult Monuments in the Udmurt Religious Tradition.] Izhevsk: Udmurtskii institut istorii, iazyka i literatury Ural'skogo otdeleniia Rossiiskoi akademii nauk.

Sokolova, Zoya 1979. Liapinsko-sos'vinskaia gruppa mansi po materialam brachnykh sviazei v XVIII-XIX vv. [Mansis of Lyapin and Sosva on the Materials of Marriage Communications in the 18th-19th Centuries.] In: Istoriia, arkheologiia i etnografiia Sibiri. Tomsk: TGU, pp. 112-130.

Startsev, Georgy 1928. Ostiaki. [Ostyaks.] Leningrad: Priboi.

Sukhoguzov, Petr 1989. Put' Moskovskogo voiska na Pechoru i za Ural v pokhode 1499_ 1500 godov. [The Route of the Moscow Army to Pechora and over the Urals in the Campaign of 1499-1500.] In: Rodniki parmy: nauchno-populiarnyi sbornik. Syktyvkar: Komi kn. izd-vo, pp. 160-163.

Tizengauzen, Vladimir 1884. Sbornik materialov, otnosiashchikhsia k istorii Zolotoi Ordy. [Collection of the Materials Relating to the History of the Golden Horde.] Tom I: Izvlecheniia iz sochinenii arabskikh. [Extracts from the Arab Works.] St. Petersburg: Tipografiia Imperatorskoi Akademii nauk.

Uliashev, Oleg 1999. Tsvet v predstavleniiakh i fol'klore komi. [Colour in the Images and Folklore of the Komi.] Syktyvkar: Komi nauchnyi tsentr UrO RAN.

Uliashev, Oleg 2011. Khromatizm v fol'klore i mifologicheskikh predstavleniiakh permskikh $i$ obskougorskikh narodov. [Chromatism in the Folklore and Mythological Ideas of the Permic and Ob-Ugric Peoples.] Ekaterinburg: UrO RAN.

Uspenskaia, Sofia 2002. Obraz Em-vosh-iki v fol'klore i verovaniiakh kazymskikh khantov. [Image of Yem-vosh-iki in the Folklore and Beliefs of the Khanty of Kazym.] In: T. A. Moldanova \& A. D. Kaksin (eds.) Materialy Viugorskikh chtenii: Medved'v kul'ture obsko-ugorskikh narodov. Khanty-Mansiisk, 22 maia $2002 \mathrm{~g}$. Khanty-Mansiysk: Poligrafist, pp. 39-55.

Zbrueva, Anna 1952. Istoriia naseleniia Prikam'ia v anan'inskuiu epokhu. [History of the Settlement of the Kama Region during the Ananyino Era.] Materialy $i$ issledovaniia po arkheologii SSSR, No. 30. Moscow: Izdatel'stvo Akademii nauk SSSR.

Zherebtsov, Liubomir 1982. Istoriko-kul'turnye vzaimootnosheniia komi s sosednimi narodami: $X$-nachalo $X X v$. [Historical and Cultural Relationship of the Komi with the Neighbouring Peoples: 10th to the Early 20th Cc.] Moscow: Izd-vo Nauka. 


\title{
SOME MOTIFS IN KOMI LEGENDS ABOUT THE CREATION OF THE WORLD
}

\author{
Pavel Limerov \\ Leading Research Fellow \\ Department of Folklore, Institute of Language, Literature, and History \\ Komi Science Centre, Russian Academy of Sciences, Russia \\ Email: plimeroff@mail.ru
}

\begin{abstract}
The article analyses some scenarios from legends about the creation of the world in the Komi tradition. The text recorded by Pavel Doronin in 1923 contains some storylines that have no parallels in similar texts. First and foremost, it is the story of the creation of the Earth, which is a contamination of mythological motifs of Earth-diving and the creation of the world from an egg. The article considers in detail the main components of the motifs and offers a hypothesis about the origins of these components.
\end{abstract}

Keywords: alkonost, cosmogonic legends, demiurge, proto-Uralic myth, scenario

\section{ORIGINAL COSMOGONIC SCENARIOS}

The myth of creating the Earth is a constituent part of cosmogonic legends. Finno-Ugric mythology knows two world-creation scenarios: 1. a waterfowl grabs the Earth from the bottom of the primary ocean (the myth of a diving bird, hereinafter the MDB), and 2. Earth and other cosmic elements are created out of a bird's egg (the myth of creation out of an egg, hereinafter the MCE).

The latter scenario is most popular among the Western Finno-Ugrians - the Karelians, Finns, Estonians, Saamis, etc., while the MDB was widely spread among the Eastern Finno-Ugrians - the Komi, Udmurts, Mordovians, and Mari (Aikhenvald \& Petrukhin \& Khelimsky 1998 [1980]: 564). Komi folklore knows both variants of the story, although the most popular legend among the researchers and those interested in folklore is the one copied in 1923 by Pavel Doronin, a writer and ethnographer, from a Komi manuscript in the village of Prokopievka (Komi Pron'dor) in what is now the Syktyvdinsky district of the Komi Republic.

The text is a well-developed version of the dualistic world creation legend. It has a clearly defined concept of antagonism between demiurge brothers 
and includes both the creation of all levels of the universe and the creation of a human being. The plot is distinguished by the presence of three, not two, waterfowls, as the beginning of the story features a duck - the mother of the future creators of the world.

The chözh duck was swimming in the primary boundless ocean-sea and carried the eggs of the origin of life. For a long time, she was looking for a place to hatch her ducklings but could not find a safe location. She laid four eggs, but the sea swallowed them and she managed to save only two eggs. Out of these eggs, two children, two ducklings, hatched under the mother duck's wing - En and Omöl'. They were two brothers, two opposite principles - life and death, good and bad, truth and lie, day and night. The mother duck carried them on her back until they came of age and then asked them to bring the lost eggs from the depth of the sea and break the eggs on her body. She flew high up the air, fell against the water, and died. (Doronin 1947)

Then, the legend tells how the ducklings dived to the bottom of the ocean to fetch the drowned eggs, revealing their antagonism: En dived first, and while he was at the bottom, 'Omöl' whistled and shouted so that everything stood still and the ocean surface froze' (Doronin 1947). En got out of the abyss, having broken the ice with lightning. The brothers broke the rescued eggs against the body of their mother duck. Out of the eggs that En broke, the Sun shined, the body of the mother duck grew longer and wider, covered up with grass and forest, and became the Mother Earth, while out of the eggs that Omöl' broke, the Moon shined, and lakes, bogs, and quicksand appeared on the Earth, and demons arose. The brothers got out of the water, stepped on the earth, and turned into human beings. En created useful birds and animals, and Omöl' predators and snakes; then, they created the first people, a man and a woman (Doronin 1947: 105-111, Komi Mythology 1999: 414-415; Limerov 2005: 17-20).

The text was first published by Fiodor Plesovsky, who also offered its first interpretation within the framework of the matriarchate theory, as approved by the Marxist science (Plesovsky 1972: 32-46). Nikolay Konakov has more than once referred to this text. His intention was to read the myths as a preliminary stage 'on the way to reconstruct the paganism of ancient Komi, and further on, the paganism of the Urals' (Konakov 1996: 5). I considered the story told by the legend part of the analysis of the Komi cosmogonic scenarios (Limerov 2002: 4-16). In this article, I will analyse some peculiarities of the scenario and pay attention to specific MCE of the Komi tradition. 


\section{KEYNOTES OF THE COSMOGONIC LEGEND: SINGULARITY OF SEMANTICS}

The analysed legend is a contamination of the MDB and MCE scenarios: a duck hatches eggs, but the world is created by two characters, who dive to the bottom of the ocean to get the eggs. The only thing that these two completely different scenarios have in common is the absence of a support point in the primary ocean that could be the place of origin of the creation. Initially, there is support point in the MDB scenario, where the earth (silt) is taken from the ocean bed, while there is a support in the Western-Finno-Ugric MCE: a bird makes her nest on Väinämöinen's knee (Karelian-Finnish), on a golden bush in the middle of the sea (Estonian), or on a tussock among the primary waters (Izhorian). The egg rolls down into the sea and breaks, and the sky, the earth, and the celestial bodies are formed out of these pieces (Napolskikh 1991: 29).

The following is a re-construction of the MCE Baltic-Finnish pre-form:

A celestial bird flies over the sea, looking for a place to nest, then it finds a tussock, lays three eggs, the wind comes, the eggs fall down in the water, and the Sun, the Moon, the stars (maybe also the earth and the sky) are formed out of the eggs (Napolskikh 1991: 30).

As we can see, the Western-Finno-Ugric version of the text has no bird diving for the egg - the bird lays eggs not on the water, but on the knee of the first man, on a tussock, a golden bush, or any other equivalent of axis mundi (mountain, world tree), and the egg breaks on its own because of the fall, not because the hero of the legend breaks it. That is to say, the MCE scenario requires a very important element as axis mundi for the cosmic egg; therefore, it does not need a waterfowl, who is indispensable for the MDB, and hence, the Estonian and Izhorian myths do not have this pre-Ural archaism.

It is easy to see that both the Baltic-Finnish and Komi MCEs are completely different. The main motif of the latter is diving, with an addition of the motif of a bird laying eggs in the water.

The latter motif (laying eggs in the water) is rather unusual for these kinds of texts and it is rare for a cosmogony. In addition to the Komi-Zyrian, the motif can be also found in a Komi-Permyak legend:

The world was a boundless ocean and a duck was swimming in it. It laid an egg and it fell in the water. A loon dived to the ocean bed, got the egg, and broke it. The top half of the egg became the sky and the bottom halfthe earth. (Konakov 1996: 18)

There is a similar legend in the Mari tradition: 
A duck dived to the bosom of the ocean. She laid two eggs and hatched them under her wings. Two drake brothers, Iumo and Iyn, were born out of the eggs. Then, they dived into the ocean one by one and brought up the earth from the ocean bed in their beaks. The earth brought by Iumo formed a level surface. Iyn choked and spit out earth and saliva. That was how mountains, lakes, and bogs were created on the Earth. (Kaliev 2004: 108)

Both texts are contaminations of the MDB and MCE, although they differ significantly from the Komi-Zyrian scenario. In the latter, the material of the world is the body of the mother duck, but in the Komi-Permyak one, it is the egg (MCE), and in the Mari one, the earth is taken from the ocean bed (MDB). ${ }^{1}$ The absence of support for laying eggs is compensated in the Komi-Permyak text by the fact that the loon breaks the cosmic egg, and in the Komi-Zyrian and Mari texts, the duck hatches the eggs under her wings. ${ }^{2}$ As Konakov (1996: 17) correctly noted, according to the original version of the Komi-Zyrian scenario, the diving bird brought the earth, and the motif of the world creation out of the egg was added later. Evidently, the MDB part of the scenario does not imply the presence of cosmic support in the primary ocean, as the primary waters are empty. Therefore, the contaminated scenario tells about laying eggs on the water. However, this is an ordinary motif neither for the MCE nor for the MDB scenarios, so we may reasonably assume its literary origin.

The parallels of the motifs can be found in the legends of the mythical alkonost (alkyone) bird, going back to Hexameron by John the Exarch and Paleia Tolkovaia (Interpretative Paleia). According to these legends, the alkonost (alkyone) lays eggs in the depths of the sea: 'Alkonost lays her eggs in the depths, and hatches them on the surface of the water' (Belova 2001: 53; Belova \& Petrukhin 2008: 177-179). The influence of the plot of the book on folklore is evident - the duck is related to the alkonost characters (laying eggs in the depths and hatching ducklings in the sea) and the solution of retrieving the drowned eggs is the traditional diving.

\section{LINGUISTIC AND SEMANTIC ANALYSIS OF THEONYMS}

For the Komi-Zyrian scenario, the death of the mother duck is unavoidable, as it is a condition for the actions of the main figures, En and Omöl' (God and Devil). The archetypical model of the dualistic myth, which forms the basis of the text, requires returning to a two-person scenario. Then, the scenario includes a description of the demiurges: 'They were two brothers, two opposite principles - life and death, good and bad, truth and lie, day and night' (Limerov 2005: 18). This description sounds somewhat artificial for an oral text, but it is from the manuscript, so the original text might have been amended by the 
person compiling the handwritten collection. Nevertheless, this description is very important for the particular text, as it expresses the dualism of the demiurges. At the level of composition, it is the main factor that structures the meaning of the rest of the legend.

The opposition between the brothers is revealed in their names as the opposition between 'top' and 'bottom'. The theonym En [enm-] has the meanings of 'god, sky'; Old Perm jen - jenm- means 'god'; Komi-Zyrian, Komi-Permyak, Komi-Yazva jen; Udmurt in - inm- means 'sky', inmar - 'god' - general Perm *jenm- means 'god, sky' // Finnish ilma means 'air, weather', Ilmari[nen] - 'god of air' (mythology) = pre-Perm *ilma- means 'air, sky' (Lytkin \& Gulyaev 1999: 99). The theonym Omöl' in Komi means 'bad, evil, poor, disgusting' (Timushev \& Kolegova 1961: 489), which opposes him to En as a 'bad god' to a 'good god'.

Konakov offered an interesting suggestion that omöl' is linguistically and genetically related to omla, omlöd, omlög 'river bay, backwater, whirlpool, deep place in the river, cavity, pit in the riverbed', and en' omla 'woman's womb' (Konakov 1996: 11; Lytkin \& Gulyaev 1999: 205). Omöl's relation to the water element is confirmed by a version that Omöl' was created from En's spit (Kuznetsova 1998: 63). Karelian and Finnish mythology have semantic and linguistic analogues to these terms. For example, according to Eino Karhu, Ilmarinen is a heavenly demiurge of pre-Finno-Ugric origin < Finnish ilma 'air, air space, sky, weather'. Väinämöinen (demiurge god) < Finnish väinä 'wide river with quiet flow'; Livonian vena 'estuary, channel'; Estonian väin, vein 'estuary, channel' (Karhu 1994: 75-76); compare: Komi omlöd - general Perm *oฑз-l3- 'pit, trench, cavity, recession'; pre-Perm *ă $a$ - 'recession, opening' (Lytkin \& Gulyaev 1999: 205). The comparison of omlöd 'deep place' with en' omla 'womb' can be explained by the similarity of 'a deep water place' and the notion of 'depth' as a symbolic 'bottom' with the female principle. Konakov (1996: 11) makes a well-justified parallel between Komi omla and ancient Turkic umai 'goddess of childbirth' and 'afterbirth, viscera, womb'. These words are close not only phonetically; they are related by the common meaning of fertility and origin, as mythology compares the birth of a child from the mother's womb to the birth of the world from the primary chaos. Nevertheless, as Sergei Averintsev notes, water as chaos refers to the principle of the universal conception and contains both male and female elements: 'As a female element, water is the analogue of the mother's belly and womb... at the same time, water is the fertilising male semen that makes the earth give birth' (Averintsev 1998 [1980]: 240). Therefore, the terms omöl' and omla form the pair of male and female related to the mythological 'bottom'.

It would be appropriate here to recall a hypothesis by Fiodor Plesovsky that the term Omöl' is related to Ioma - a goddess of the matriarchate period, who later transformed into a male god during the patriarchate. He thinks that 
Ioma-Omöl' is a borrowed and inverted name of the western-Finno-Ugric god Jumal, Jumala (Plesovsky 1972: 38).

Konakov also believes that Omöl' is a linguistic analogue of Jumala, Jumalthe theonym of the western Finno-Ugrians. In his opinion, due to the taboo to pronounce the name of the evil god, the Komi used the foreign theonym of the Finnish higher god as a euphemism to refer to their 'dark god' (Konakov 1996: 10-11). The female alter ego of this 'dark' god is revealed in the name of a fairy tale character Ioma and her analogues in the Finnic languages: Komi ioma 'witch' (juma in the Udora dialect of the Komi language) < Finnic, compare Finnish jumala 'god', dialect maajumala 'witch' (Lytkin \& Gulyaev 1999: 100). However, we do not see this as a loan from the Finnic languages, as Komi terms omöl' and ioma have Indo-European linguistic parallels, just like Finnish jumala, jumal.

Setting aside the concept of the primacy of matriarchate, Fiodor Plesovsky's theory about the division of a unique god into male and female counterparts reflects the cosmogonic idea of the division of the primary androgen into the male and female halves. This necessarily implies parallels with the characters of the Indo-European mythologies: Imir is a primary ancestor in the Scandinavian mythology (etymologically, ymir means double, i.e., a bi-gender creature or twin, cf. Irish emnin 'twin', Latvian jumis 'double foetus') (Meletinskiy 1998 [1980]: 510). Ymir, in turn, is genetically related to Indo-Iranian mythological Yama and Yami (Rigveda), Jima and Jimak (Bundahishna) - the couples of the first people, who were the ancestors of the humankind. The names of these characters have the etymological meaning of 'twin' or 'double' (Lelekov 1998 [1980]: 599). Taking into account this correspondence, Ioma would be a twin of Omöl' and, perhaps, this is a theonym of a female god of fertility, similar to the notion of the Mother-goddess (Turk Yumai).

The word omöl' may, through pre-Perm *ăya- 'recession, opening' (Lytkin \& Gulyaev 1999: 205), come from the general Finno-Ugric notion of a woman's womb as a mythical primary principle of origin, chaos. In other words, if the name of the first demiurge $E n$ is related to the notions of 'sky, top, light', i.e. the 'upper world', then the other, demiurge Omöl', would be related to the notions of 'water, darkness, woman's womb', which is semantically equal to the 'bottom' and 'lower world'. Therefore, the term omöl', denoting the 'dark' demiurge, can be the primary theonym to the word omöl' 'bad' and also a primary theonym similar to Kul'.

\section{MOTIF OF THE ANTAGONISM OF DEMIURGES}

The cosmogonic characters are brothers and often they are twins, so the scenario of the legend grants them equal rights in the future universe. Konakov (1996: 12) sees the idea of the original unity of chaos in this primary neutrality of the 
demiurges - as soon as creation begins, the brothers take on opposite roles. Nevertheless, the characters of the diving birds vary in the similar legends of other nations: usually, they are a duck (goose, swan) and a loon, and this variety of the divers' images goes back to the original forms of the text, i.e., the proto-Uralic myth (Napolskikh 1991: 62-63).

In diving for the drowned eggs, the brothers show first signs of rivalry. This incident includes a unique motif of acoustic differentiation of the opponents: while the diving $E n$ is at the bottom of the sea, Omöl' whistles and shouts so that the ocean surface freezes. En responds with thunder and lightning. Whistling and thunder have no parallel in the MDB of any tradition, though its ethnographic analogue can be the Komi belief in the opposition of the two elements: the whistle is associated with evil forces, the wicked dead, the northern wind, while the thunder is associated with God and Prophet Elijah. According to Anatoly Panyukov (2006: 129), 'making chaos sound' is one of the first cosmogonic actions. In other words, this is the first instance of the cosmos existing as an audible structure, and the sounds of the structure have an innate hierarchy - the 'freezing whistle' made by Omöl' is hierarchically lower than $E n$ 's sound of thunder. In other Komi cosmogonic texts, the Omöl' loon makes sounds ('kurlyk-kurlyk'), hoping to scare the En swan, but En answers with thunder and lightning (Limerov 2005: 17). The whistle and the thunder are opposite forces, expressing different degrees of the brothers' creative powers, while Omöl's 'freezing whistle' is literally suppressed by En's thunder and lightning. ${ }^{3}$

That is how the principle of divine suppression of any chaotic manifestations, emanated by the 'dark' co-creator, is ontologically built in the structure of the newly created world. This makes clearer the mechanism of the euphemistic naming of the dark elements on the basis of the semantic pair en (strong, powerful) versus omöl' (poor, bad, weak), as noticed by Konakov (Konakov 1996: 10). ${ }^{4}$

It is worth mentioning that the motif of freezing water is also known in the Komi tradition from a text collected by Alexei Sidorov in 1913: the devil, transformed into a loon by God, dives for the earth, but when going from the bottom up to the surface of the sea, the sea is covered with ice (Limerov 2005: 25). The text does not say explicitly that it was God who froze the water, but it is implied. Perhaps it is a shortened version of the South Slavic cosmogonic legend about stealing a valuable item from Satan:

God sends an angel to collect a valuable item from Satan. The angel tricks Satan into diving to the bottom of the sea, takes the valuable item left onshore, and flies back to the heaven. God covers the sea with ice to stop the pursuit, but Satan breaks through it, chases the angel, almost reaches him, but fails to get back the stolen item. (Kuznetsova 1998: 70)

As for the analysed scenario, however similar the look, the motifs of freezing the water in the Komi and South Slavic texts have different meanings. In the Komi 
legend, the whistle and the ice are immanent to the image of the 'dark demiurge' and illustrate his thrive to win the 'light' brother, while the Slavic motif, according to Aleksandr Veselovskiy (2009: 313), traces its origin to the Bogomil versions of the scenario, where Satan creates the sun crown and God steals it.

\section{OTHER SCENARIOS: PROSPECTS OF STUDYING}

Out of the six eggs laid by the duck, two contain antagonist demiurges and the other four the energies of creation and destruction. That is why the motif of breaking the eggs is so important, as it refers to the release of the energies. Some of the energies set free by the light demiurge transform the quality of the original cosmic material, the body of the duck, and become the earth covered with woods and greens, where the Sun shines in the sky, while the dark demiurge sets free the negative energies, and the Moon appears in the sky, and everything created by the first demiurge shows signs of death: 'lifeless waters flowed on the earth, lakes, bogs, and quicksand opened the abysses' (Limerov 2005: 18).

As soon as the earth was formed, the original unity of the ocean was substituted for the binary combination of water and earth. Then the construction of the dual cosmos begins, originally caused by the antagonism of the mythological characters. Practically all known legends coincide in that the 'dark' demiurge (Satan) spoils whatever his 'light' brother (God) has created and that is why the world is not perfect. As a general rule, the active opposition of the creators is introduced into the scenario by the motif of 'concealing earth': Satan keeps in his mouth some of the earth that he got from the sea bed and spits it on the earth created by the God, which gives rise to mountains, lakes, ravines, etc. on the smooth surface (Kuznetsova 1998: 71). ${ }^{5}$ Komi legends do not have this motif, and the 'spoiling' of the Earth created by En God is explained by the Omöl' Satan being initially 'evil'. In fact, the spoilage of the relief is included in the analysed text only, although it is related to setting the negative energy free from the cosmic egg by the Omöl' Satan. Similarly, the creation of angels and demons is shown as freeing them from the egg, unlike the traditional version of carving them of stone.

The motifs I have analysed represent only the beginning of the original cosmogonic legend. The unique versions of anthropogenesis, cosmic war, and repartition of the world are beyond this article.

\section{NOTES}

1 Vladimir Napolskikh quotes a Latvian version of the MCE as a parallel example of creating the Earth out of the duck's body: God tears apart an eagle and its blood becomes the sea, its body - the mud and the silt. God breaks the egg found inside the 
eagle and the top part of the egg becomes the sky and the bottom part, which fell into the sea and was mixed up with the silt, becomes the earth (Napolskikh 1991: 32).

${ }^{2} \mathrm{~N}$. Konakov interprets this motif as a version of a 'miraculous birth': the way how magic creatures were born in mythological traditions; in the Komi tradition, the godmother gave birth to Jesus from her right armpit (Konakov 1996: 17). Yuri Kaliev also supports this version (2004: 109).

${ }^{3}$ Compare to a Russian legend: 'Following the motion of God's rod, the celestial army appeared, and following the Satanail's whistle, a host of demons' (Kuznetsova 1998: 347).

4 N. Konakov has all the reasons to believe that the term Kul' can be the original name of the dark god, while Omöl' is a euphemism.

5 V. Napolskikh thinks that this motif appeared in the Finno-Ugric and Turk texts under the influence of a popular Christian, maybe Russian tradition (Napolskikh 1991: 138).

\section{REFERENCES}

Aikhenvald \& Petrukhin \& Khelimsky 1998 [1980] = Aikhenval'd, Aleksandr \& Petrukhin, Vladimir \& Khelimskii, Evgenii. Finno-ugorskaia mifologiia. [Finno-Ugric Mythology.] In: Sergei Tokarev (ed.) Mify narodov mira: Entsiklopediia. [Myths of the Peoples of the World: Encyclopaedia.] T. 1. Moscow: Bol'shaia Rossiiskaia entsiklopediia, pp. 563-568.

Averintsev, Sergei 1998 [1980]. Voda. [Water.] In: Sergei Tokarev (ed.) Mify narodov mira: Entsiklopediia. [Myths of the Peoples of the World: Encyclopaedia.] T. 1. Moscow: Bol'shaia Rossiiskaia entsiklopediia, p. 240.

Belova, Olga 2001. Slavianskii bestiarii: Slovar' nazvanii i simvoliki. [Slavic Bestiary: Dictionary of Names and Symbols.] Moscow: Indrik. Available at https://inslav. ru/images/stories/pdf/2001_Belova_Slavianskij_bestiarij.pdf, last accessed on 17 June 2019.

Belova, Olga \& Petrukhin, Vladimir 2008. Fol'klor i knizhnost'. Mifi istoricheskie realii. [Folklore and Book Culture: Myth and Historic Reality.] Moscow: Nauka. Available at https://inslav.ru/publication/belova-o-v-petruhin-v-ya-folklor-i-knizhnost-mifi-istoricheskie-realii-m-2008, last accessed on 17 June 2019.

Doronin, Pavel 1947. Materialy $i$ dokumenty po istorii komi. [Materials and Documents on Komi History.] Nauchnyi arkhiv KomiNTs UrO RAN: F.1, Op. 12, D. 25. L. 105-111.

Kaliev, Yuri 2004. Etnokul'turnyi status mifologicheskogo soznaniia: Genezis, funktsionirovanie $i$ evoliutsiia traditsionnogo mirovospriiatiia (na primere mariiskoi mifologii). [Ethnic and Cultural Status of Mythological Consciousness. Genesis, Functioning, and Evolution of Traditional Perception of the World (Evidence from Mari Mythology).] Diss. (PhD Thesis). Chuvashskii Gosudarstvennyi Universitet.

Karhu 1994 = Karkhu, Eino. Karel'skii $i$ ingermanlandskii fol'klor $v$ istoricheskom osveshchenii. [Karelian and Ingrian Folklore in Historical Perspective.] St. Petersburg: Nauka.

Komi Mythology 1999 = Siikala, Anna-Leena \& Napol'skikh, Vladimir \& Khoppal, Mikhai (eds.) Entsiklopediia ural'skikh mifologii. T. 1. Mifologiia komi. [Encyclopaedia of 
Uralic Mythologies. Vol. 1. Komi Mythology.] Moscow \& Syktyvkar: DIK. Available at https://www.academia.edu/8463469, last accessed on 17 June 2019.

Konakov, Nikolai 1996. Traditsionnoe mirovozzrenie narodov komi: okruzhaiushchii mir. Prostranstvo i vremia. [Traditional Views of Komi Peoples: Environment. Space and Time]. Syktyvkar: Izdatel'stvo Komi NTs UrO RAN.

Kuznetsova, Vera 1998. Dualisticheskie legendy o sotvorenii mira v vostochnoslavianskoi fol'klornoi traditsii. [Dualistic Legends about the Creation of the World in the Eastern-Slavic Folklore Tradition.] Novosibirsk: Izdatel'stvo SO RAN.

Lelekov, Leonid 1998 [1980]. Iima. [Yima.] In: Sergei Tokarev (ed.) Mify narodov mira: Entsiklopediia. [Myths of the Peoples of the World: Encyclopaedia.] T. 1. Moscow: Bol'shaia Rossiiskaia entsiklopediia, p. 599.

Limerov, Pavel 2002. Siuzhety o sotvorenii zemli v komi fol'klornoi traditsii. [Scenarios of the Creation of the Earth in Komi Folklore Tradition.] In: Pavel Limerov (ed.) Fol'kloristika komi. Trudy instituta iazyka, literatury i istorii, Vyp. 63. [Komi Folklore Studies. Proceedings of the Institute of Language, Literature, and History. Vol. 63.] Syktyvkar: Izdatel'stvo Komi NTs UrO RAN, pp. 4-16.

Limerov, Pavel (comp.) 2005. Mu puks'öm - Sotvorenie mira. Mifologiia naroda komi. [Creation of the World. Komi Mythology.] Syktyvkar: Komi knizhnoe izdatel'stvo.

Lytkin \& Gulyaev 1999 = Lytkin, Vasilii \& Guliaev, Evgenii. Kratkii etimologicheskii slovar' komi iazyka. [The Concise Etymological Dictionary of the Komi Language.] Syktyvkar: Komi knizhnoe izdatel'stvo.

Meletinskiy 1998 [1980] = Meletinskii, Eleazar. Imir. [Ymir.] In: Sergei Tokarev (ed.) Mify narodov mira: Entsiklopediia. [Myths of the Peoples of the World: Encyclopaedia.] T. 1. Moscow: Bol'shaia Rossiiskaia entsiklopediia, p. 510.

Napolskikh, Vladimir 1991. Drevneishie etapy proiskhozhdeniia ural'skoi iazykovoi sem'i: Dannye mifologicheskoi rekonstruktsii (praural'skii kosmogonicheskii mif). [Ancient Stages of Origin of the Uralic Language Family: Mythological Reconstruction Data (Proto-Uralic Cosmogonic Myth).] Narody Ural'skoi iazykovoi sem'i. [Peoples of the Uralic Language Family.] Vyp. 5. Moscow: Institut etnologii i antropologii AN SSSR. Available at https://www.academia.edu/14755985, last accessed on 17 June 2019.

Panyukov 2006 = Paniukov, Anatolii. Marginalii komi muzykal'noi kul'tury: Mir ptits. [Margins of Komi Musical Culture: World of Birds.] In: T. Kaneva (ed.) Narodnaia kul'tura Evropeiskogo Severa Rossii: Regional'nye aspekty izucheniia. [Folk Culture of European North of Russia: Regional Aspects of Studies.] Syktyvkar: Izd-vo SyktGU, pp. 126-150.

Plesovsky 1972 = Plesovskii, Fedor. Kosmogonicheskie mify komi i udmurtov. [Cosmogonic Myths of the Komi and Udmurts.] In: Iakov Beznosikov \& Anatolii Mikushev (eds.) Etnografiia $i$ fol'klor komi. [Komi Ethnography and Folklore.] Vyp. 13. Syktyvkar: Izdatel'stvo Komi filiala AN SSSR, pp. 32-46.

Timushev, Dmitriy \& Kolegova, Nina (comps.) 1961. Komi-russkii slovar'. [Komi-Russian Dictionary.] Moscow: Gosudarstvennoe izdatel'stvo inostrannykh i natsional'nykh slovarei.

Veselovskiy 2009 = Veselovskii, Aleksandr. Dualisticheskie pover'ia o mirozdanii. [Dualistic Beliefs of the Universe.] In: Sergei Levit (ed.) Izbrannoe: Traditsionnaia dukhovnaia kul'tura. [Selected Works: Traditional Spiritual Culture.] Moscow: Rossiiskaia politicheskaia entsiklopediia, pp. 263-361. 


\title{
ZAUM (BEYONSENSE, EDUCANTO) IN THE KOMI TRADITION OF INCANTATIONS: REVISITING THE ISSUE OF ORIGINS
}

\author{
Anatoly Panyukov \\ Leading Research Fellow \\ Folklore Archive, Institute of Language, Literature, and History \\ Komi Science Centre, Russian Academy of Sciences, Russia \\ Email:apankomisc@mail.ru
}

\begin{abstract}
In order to provide a general overview of particular aspects of the topic in the title of this article, the author suggests having a look at one specific example from the Komi tradition of incantations. In the analytical part of the article, the author makes a hypothesis: Linguistic transformations verified as zaum (beyonsense, educanto) can occur as a result of compression of a source text (pretext, prototext) into a rhythmical matrix of the act of incantation. By the rhythmical matrix we mean a complex fixed structure of rhythmical subsystems: sound-rhythmical, rhythmo-melodic, metrical-rhythmical, and other dimensions. The compression of the prototext into the text of an incantation can have a non-linear character and be the result of a peculiar strategy of the transfer of knowledge pertaining to incantations from a teacher to a student. By virtue of a number of specific psychophysiological attitudes and limitations, the student does not remember the text of the incantation, but reproduces some deeper levels of the magical and ritual performative related to the rhythmical matrix. And it is into the matrix reproduced by his or her consciousness that a new verbal stream made up of the components of the source text, fixed in the short-term memory of the student, is incorporated.
\end{abstract}

Keywords: borrowings, folklore, incantation zaum, Komi-Zyrians, rhythm, rhythmical matrix, structure

\section{INTRODUCTION}

Folklore zaum is a phenomenon that is versatile and multi-faceted both in its origin and functions (which serve a wide range of ritual, magical, and game forms of communication with the 'other' world), and in the degree of being distant from the natural language (both in phonetic terms, i.e. 'pure nonsense', when the sounds do not add up into morphemes, and in the suprasyntactic sense, when, 
even though the formal and grammatically correct language structures are used, it is still fundamentally unclear what the text refers to) (Janecek 1996).

The interrelation of all kinds of zaum with the mother tongue of the carrier, which is generally recognized today (any kind of zaum is the actualization of the linguistic and cultural dominating idea) assumes the search for meanings, engrained in it, on the fringes of the standard language, within the realm of sound-semantic associations that are relevant for the performer/listener (Shlyakhova 2006). The subjective factor, the predominance of the emotional and intuitive origins in terms of perception of zaum determines the probabilistic nature of textual research. However, it does not deny us the opportunity to speak about certain formal and conceptual rules of organizing zaum texts (Panyukov 2010). The approaches to the interpretation of poetic zaum that currently prevail assume the search for the semantics of the texts through semantic 'translation' of detectable implications: intralinguistic, foreign, pertaining to a foreign culture. The most radical analysts have put forward the opinion of the fundamental semantic openness, i.e., the decipherability of zaum (Davydov 2007: 66).

With regard to the Komi tradition of incantations, the pathos of the avenues for interpretation is mainly held back by the blurriness of the borders of the linguistic mode itself, which is determined as zaum. If we approach it from the perspective of distancing ourselves from the dominant linguistic structure, we will see that there are linguistic 'shifts' that can be qualified as zaum in almost every single incantation text. First of all, it is related to the abundance of Russian-language components that take on a different underlying rationale in the monolingual environment and are not simply incorporated into the repertoire, but also into a poetic armoury of the tradition (in the form of text-building elements with ambiguous semantics - quasi morphemes, quasi words, quasi syntactic structures of different levels of complexity). In addition to that, the 'internal' specific character of this genre contributes to the semantic ambiguity of the texts of incantations. In an extended sense, the word нилкььв 'incantation' means a combination of the means of word-magical impact on nature, which are different in the means of organization of verbal text (Ulyashev 1999). The incantations - нимкыь - get their specific ellipsoid structure, which requires the context of knowledge, from the nominative mode of text-building that is concept-based and correlates with the literal meaning of this term (ним 'name' $+\kappa ы є$ 'word, language'), while нимкыв represents a certain combination of key words or consists of one word only (Ulyashev 1999). Hence a number of topical issues arise when enunciating the topic of zaum (beyonsense, educanto) in the Komi tradition of incantations itself, which are related both to the origins of certain phenomena of zaum and their existence. In order to specify the gist of the problem, let us have a look at the text of a borrowed incantation which is representative of the current state of the tradition. 


\section{ZAUM IN A BORROWED INCANTATORY TEXT}

On the basis of the submitted analytical calculations I will analyse the incantation text which is alien, i.e. in Russian. This incantation is related to traditional magical and medical practice, but there is only a written fraction of the act of incantation in my possession.

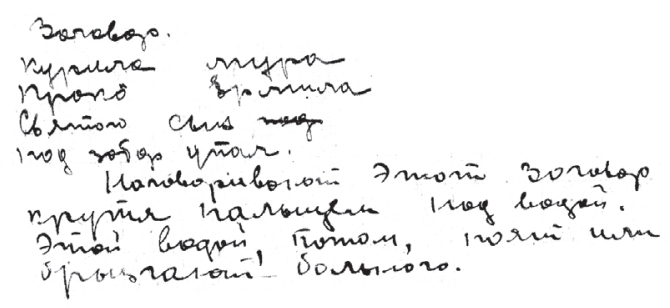

Курила мура

Прокӧ Ерлила

Святого сын

Под забор упал.

This incantation is said while swirling a finger under water. Then a sick person is washed or splashed with this water. ${ }^{1}$

According to the data in the archives, this incantation was recorded by a student of Syktyvkar Pedagogical College during folklore fieldwork in June 1935. Unfortunately, the collector did not record the passport data of the reciter, but, proceeding from some other records, we can assume that this text could have been recorded in Grivensky village soviet, Koygorodsky District, the Komi Republic. However, in terms of its linguistic characteristics, it may be said that, regardless of its obvious characteristics referring to the Russian language, it was recorded from someone speaking the Komi language.

\section{Textual aspect}

First of all, let us have a closer look at the actional level. According to the actions that accompany the incantation process, this is an adaptation of the tradition of the magical evil-eye treatment which is widespread in the Komi tradition - вомидз, in which splashing with charmed water and giving it to drink can complement each other. For example, in the methods of treatment of волидз, which were described in detail by Sidorov, after being splashed with charmed water, a sick person was given this water to drink, 'so that the disease would not rush into the intestines'; besides, sometimes a 'shower' was given to a sick person using charmed water: to do that, a sieve was set up above the stove (cëp), and water was poured through it right on the sick person sitting under the sieve (Sidorov 1997 [1928]: 159). However, in this case, we are dealing with a simplified version of preparing charmed water, which does not require any special conditions or attributes (a strong connection with a specific time 
of day or place, crossing water with a knife, using stones, pouring the water through stones or a door handle, etc.). Perhaps we are seeing here a 'mobile' adaptation, which developed occasionally, i.e., the one that can be easily reproduced in any conditions of treatment, and no parallels have yet been found to it in any other traditions. Nevertheless, it is this kind of adaptation that is unusual for the incantation tradition that has the 'primary motivation' of some kind - it is a whirlpool. In the cultures of many different peoples, water taken from a whirlpool is attributed with magical features (see Vinogradova 2002: 35 about the Slavic traditions). The Komi-Zyrians entrusted sand taken from a whirlpool with magical features, too:

The sand that is taken from the whirlpool in the river has the special quality of exterminating bedbugs in living quarters. In all likelihood the belief is based on the fact that in the whirlpool the sand whirls and makes circles, which makes it magical. (Sidorov 1997: 211)

Proceeding from the fact that this text is in the Russian language which became deformed as a result of entering a foreign linguistic environment, let us 'read' it according to the rules of the Russian prosody:

$$
\begin{aligned}
& \text { КУРиЛА МуРА } \\
& \text { ПРоКӦ ЕРМиЛА } \\
& \text { СВЯТоГО СьН } \\
& \text { ПоД ЗАБоР УПаЛ. }
\end{aligned}
$$

The text consists of two parts (microtexts) that are different from each other both in formal and semantic features.

Microtext 1 is a clearly deformed fragment of the Russian text with the component ПРоКӦ from the Komi language, which is probably the local form of the name Procopius. Correspondingly, the line Прокӧ Ерлила could be interpreted either as a local form of the full name Yermil Prokopyevich or as a list of names (there are no punctuation marks in the manuscript). Additionally, in morphological terms, the word ерлила is similar to the word курила, and we should not rule out the possibility of verbal apprehension here.

Microtext 2 is a grammatically correct sentence in the Russian language СВЯТоГО СыН ПоД ЗАБоР УПаЛ.

At first glance, microtext 2 really looks like a quote from the Russian text (a prototext) that has been divorced from its context. However, it is sufficient to know the Russian incantation tradition in very broad terms in order to see the apparent foreignness of this quote. While the image of the Holy Son could fit in the system of incantation characters (provided that the functions that correspond to sacral characters exist), the motive of a sacral character falling 
off the fence contradicts the incantation image of the world, and at best, it could be interpreted as a mockery of tradition.

Such a reconstruction of the prototext becomes even more absurd if the lexical content of microtext 1 is interpreted in a similar way. If we consider (in the same line with ПРоКӦ ЕРМиЛА 'Yermil Prokopyevich' / 'Procopius, Yermil') the word $M y P A$ as an anthroponym or a personym, and the word $К У P u Л A$ as a Russian verb (thus restricting the degree of beyonsense with the syntactic level: a syntactically correct structure of word groups that does not have a coherent meaning), the motif of a sacral character falling off a fence could be subjoined with the motif of the character named Mura who was smoking / enveloping with smoke someone named Prokö Yermil / Procopius, Yermil, or the character named Mura was smoking / enveloping with smoke, and the character named Prokö yermila. The scenario that we are getting falls into place and makes a specific 'plot', but it is obvious that further searching in this particular textological direction would not lead us to the protosources we are looking for.

This is why we should go back to where we started and consider this text from the perspective of the dominant language, i.e., the Komi language. Since the lexical content clearly contradicts it, I will pay closer attention to the structural characteristics of the text and find the most generalized and conceptually feasible way to approach the topic of the Komi tradition of incantations. Let us list the points of reference once again:

- We have the text of an incantation that was recorded from a Komi speaker and existed in the Komi tradition;

- In spite of the fact that the magical act itself is incomplete, the text of the incantation was recorded in full, and, most likely, it was used within the tradition in the same form we can see it now;

- In its lexical and syntactic structure, the text is aimed at the Russianspeaking environment, and, with great probability, it originates from a prototext (or prototexts) in Russian, while its genre distinctness is unknown to us; - Correspondingly, we have a text with inexplicit semantics, which assumes the search for meanings engrained in it on the fringes of standard language.

\section{Phono-semantic aspect}

Let us proceed from the fact that this is the text of incantation that existed in the Komi tradition. The trend of stressing the first syllable in words, observed in the Komi language, had an impact on the old borrowings from the Russian language, too, and in this particular case, such borrowings are КуРИТНЫ 'to smoke', and СЬВаТӦЙ 'sacred, holy' (although here we can also draw on the 
Church Slavonic word СВяТЫЙ). Using the first line of the text as a template (it gives a specific syllabic and rhythmical pattern), we can try to reconstruct the prosodic image, or, in terms of rhythmics, the lexical rhythm ${ }^{2}$ of this incantation. We must pause to say that we do not touch upon pitch specifications of stress: in the Komi-Zyrian language, the stress is tonic, and it is different from expiratory and longitudinal stress in Russian, and the symbol 'v', as a matter of fact, means not so much the stress as toning up.

As a result of such a reconstruction, we get an almost perfect dactylic dimeter with a pyrrhic that marks the endings of the lines:

$$
\begin{aligned}
& \text { КуРИЛА МуРА } \\
& \text { ПРоКӦ ЕРМиЛА } \\
& \text { СВяТОГО СъН } \\
& \text { ПоД ЗАБОР уПАЛ }
\end{aligned}
$$

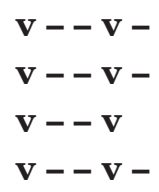

In addition to the only inaccuracy with cadency in the third line (one unstressed syllable is missing), we have one morphological inconsistency with the Russian language (if we draw on the thesis concerning the existence of the prototext in Russian), which can be explained as follows: ПоД-ЗАБОР is the acceptable clitic in the Russian speech (a preposition is merged with the next word); formally, the substantiated transfer of the stress in the word $y \Pi А Л(<У \Pi а Л)$ is consistent with the rhythmical structure. Here we should pay attention to an orthographic 'holdback' the collector experienced: at first, the preposition nод was written in the same line with the preceding expression святого сын, but then it was crossed out. It confirms my suggestion about the existence of a prosodic shift, which could cause fallacy in the sound perception.

The validity of further interpretation in the same vein is supported by the fact that the reconstructed rhythmical structure allows certain parallels between the verbal and actional codes to be observed. If we correlate the rhythm with the action done while saying the incantation (swirling a finger in water), it would be logical to assume that every single foot corresponds to one finger twist; correspondingly, swirling a finger is an irregular impulsive motion (rhythm $3 / 4+2 / 4$, which concurs with the rhythm of the incantation. In other words, this rhythmical (metrical and rhythmical) structure of the incantation is best matched to the actional level.

Now let us have a look at the only inaccuracy with cadency in the third line (one unstressed syllable is missing) and try to interpret it:

$$
\mathbf{v}--\mathbf{v}
$$


If we make an attempt to restore the 'pure' metric pattern of microtext 2 , the most feasible option would be the following:

\section{СВяТОГО СыНА ПоД ЗАБОР УПАЛ}

$$
\begin{aligned}
& \mathbf{v}--\mathbf{v}- \\
& \mathbf{v}--\mathbf{v}-
\end{aligned}
$$

While being metrically correct, this adaptation is erroneous in terms of Russian grammar, since there is no case agreement. This is why we can assume that the omission of an unstressed syllable is the result of correcting microtext 1 to make it properly Russian. This correction could have been made later, in the course of existence of the incantation within the tradition and, perhaps, it is the result of interference of yet another linguistic consciousness, the carrier of which also knew Russian to a certain extent. There is also a chance that such a correction could have been made at the moment of recording the incantation, since for the student-collector, and, probably, also for its performer in 1935 this grammar inaccuracy was obvious and could be regarded as a speech error.

The 'incorrect' word group святого сына elicits strong associations with a commonly known prayer formula 'In the name of the Father, and the Son, and the Holy Spirit (Amen)'. In the incantatory practice of the Komi, this formula was very widespread, and it could be used both as an independent нилкьвincantation and as a part of some other verbal texts (I will have a look at some of them below); besides, it was common in parochial practice, too. However, it should be pointed out that the association that emerges between the image of the 'Holy Son' and the formula of the prayer is non-linear, i.e., the Holy Son is not a direct quote from the texts, but rather a concentrate of some kind, an evocative and semantic cross-section of that formula. In order to understand the underlying principle for such a concentration (= transformation), we can refer to the method of positional analysis of the text, which is based on the idea of the golden ratio as the optimality proportion (Moskalchuk 1998). This golden ratio proportion is matched by the harmonious centre of the text (hereinafter referred to as the $\mathrm{HC}$ ), which is determined by the coefficient of 0.618 from the whole. The extensive factual material proves that it is the position of the HC in the text that is culminative on semantic, intonational, rhythmical, and other levels of its organization (Moskalchuk 1998, 2003; Korbut 2005).

\section{ВО иМЯ ОТЦа И СыНА И СВЯТоГО ДуХА (АМиНЬ) > СВяТОГО $\mathrm{Cb} \mathrm{HA}$}

Since I am only interested in the position of the HC in the whole text, the procedure for determining its location is quite simple: I take the total number of elementary units in the text as 1 and determine the proportion point as 0.618 : 0.382. Proceeding from the fact that I am dealing with a borrowing, a phonetic 
word or a syllable can be used as an elementary unit for the purposes of the positional analysis, or as a minimum element of the syllabic-rhythmical structure.

After a number of simple calculations, it turns out that the $\mathrm{HC}$ of this 14 (16)-syllable (or 5 (6)-word) text (admitting the possibility of the omission of the word Amen in the formula) is between syllables 8 and 9 (or between the 3rd and the 4 th words), i.e., either on the second syllable of the word son or between the words son and Holy. Consequently, we can assume that, as a result of the transformation (compression) of a specific prayer formula (which is perceived by linguistic consciousness and, respectively, stands out syntagmatically in the original prototext of the incantation as a separate microtext), the final text still has a component that corresponds to the $\mathrm{HC}$ of the formula $<$ the Son and the Holy>. The inversion of the component <the Son and the Holy> into the Holy Son can be related to the principle of teleologicity of the 'assembly' of the textual structure of the incantation (from the end to the beginning).

Moreover, if we do the same positional analysis of the entire incantation under consideration, we will see that the $\mathrm{HC}$ of the entire text (19-syllable or eight-word) is consistent with the HC of the prayer formula and is also located between the words Holy and Son. Additionally, several other levels of the dimensioning of the text are converged at this point: the same $\mathrm{HC}$ will remain both on the level of metrics and strophics:

КуРИЛА МуРА
ПРоКӦ ЕРМиЛА
СВяТОГО * СъН
ПоД ЗАБОР УПАЛ

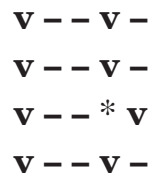

Thus, regardless of the semantic (lexical) incoherence, the incantation under consideration has a rigid structure and is harmonized. The component of the Holy Son, which lies at the heart of the HC, results from the non-linear transformation of the prayer formula, which was included in the prototext in Russian.

While the origins of the personym of the Holy Son in this incantation are more or less feasible, the motif of 'falling off the fence' looks even more absurd against such a prototextual background. This is why I will try to approach this motif from the same position of non-linearity, i.e., not to take it as a fragment of a prototext, but as an adaptation, or a compression of some prototexteme (the incantation formula, a paroemia, etc.).

So then, now we have a starting point that is reliable enough, i.e., the existence of a prayer formula in the prototext. By confining myself to the adaptations of the treatment of the evil eye that are available, I have taken notice of another borrowed incantation against волидз 'the evil eye': 
Спаса-Варука,

Причистая владька,

Железный стьн,

Медные ворота!

Отойдите от меня,

Отшатните от меня

Все нечистьье дуки

Все виды и все болезни. Сал Кристос "благослови Кристос"

Во имя отиа... Алинь.

(Sidorov 1997 [1928]: 163-164)

It is highly likely that this text was rewritten by Sidorov from the manuscript found in the village of Lopydino, on the banks of the Lokchim River (Middle Vychegda). We can see that this text also ends with the same final formula of 'In the name of...', and the incantation itself is a combination of typical guarding (protective) formulas. However, it clearly has the traces of specific perception of the semantic organization of a Russian incantation, whereby the attributive Спасова рука has transformed into a double personym (agionym) CnacaВарука. Perhaps the reason for that was the association with the name Варук / Варука 'Varyuha (Varvara)', which complements Причистую владыку.

Another reason for such a rethinking could be a change in the rhythmical structure of the incantation, in which the Russian word рука gained stress on the first syllable $P y K A$. In particular, this is evidenced by the emergence of the adaptation containing the plural form РуКИ:

Христос во всем скӧт и двор, благодатнӧй дом, круглӧй во дворы, крепкой стын, железной стын, неотданнӧй ворота; от зелли до небеса спасовая руки, Пречистая зальти, Христос печать. (Nalimov 1908: 1110)

This prayer, said when closing the gates, was recorded by V.P. Nalimov on the lower banks of the Sysola River at the beginning of the twentieth century. Unfortunately, this was a handwritten note, too, and its rhythmical structure cannot be reproduced. However, judging by the previous formula, the ending was the following: СПаСОВАЯ РуКИ, ПРЕЧиСТАЯ ЗаМЫТИ, ХРИСТОС ПеЧАТЬ.

We can mark the aspects that are of the utmost importance within the context of this research:

- The attributive Спасова рука, in view of its semantic ambiguity and obscurity for the Komi performers, has increased variation;

- In all of the adaptations that were considered, the word РУК $a$ was transformed into a trochee $(P y K A / P y K И)$; 
- In addition to that, the component CПаСОВA РуКA / CПаСA-ВАРyКA

/ СПаСОВАЯ РуКИ is a suitable 'blank' for the dactylic dimeter with a pyrrhic, i.e., for the rhythmical structure of the incantation.

Using the above-mentioned aspects as a basis, I propose the following adaptation of the non-linear transformation:

\section{СПа COBA РуKa}

\section{ПоД ЗАБОР уПАЛ}

Since the incantation under consideration, being a distinct spoken form, could be characterized by intonational and articulatory emphasis, a number of phonetic changes can be related to the peculiarities of this verbal-magical register:

- As a result of articulatory emphasis, the fricative $/ \mathrm{v} /$ turned into a voiced hard consonant /b/: СПаСОВA > СПаСОБА;

- As a result of articulatory emphasis, the voiceless /S/ became a voiced /Z/: СПаСОВА > СПаЗОБА; in addition to that, the vocalization of consonants (intervocal and the ones at the beginning of a word) is typical of the KomiZyrian language. The incipit of the Komi wedding lamentation ' Пазда да Причистая' (< Spas da Prichistaja) $)^{3}$ is cited as another adaptation of the vocalization.

- Assimilation of consonants: CПаСOBA РyКA > СПаСABA - РyПA;

- Prosodic shifts caused by etymological associations СПаЗАБА РуПА > (С)Па ЗАБА-Р уПА(Л).

Apparently a number of other consistent phonetic changes could be pointed out in addition to what has been mentioned already. However, the aspects described above are sufficient for imagining the overall order of the reconstruction.

СПаСОВА РуКА > СПаСАВА - РУПА > Па - САВАР - уПА(Л $>$ Па ЗАБАР уПА(Л) > Па(Д) ЗАБАР уПАЛ > ПоД ЗАБОР уПАЛ

Moreover, there could also be involved an intermediate link accomplishing the sound-and-meaning function, i.e., the borrowed word завор 'a taken-down picket fence', 'the gate in the fence for passing through' < Russian 'village gate, fence, hedge, picket fence' (Lytkin \& Gulyaev 1999: 104); it was recorded in all of the dialects of the Komi language and, apparently, was borrowed quite early, which is why the etymologization of a nonsemantic савор into завор (and later on into забор) was something that could be expected.

I do not have a stable formula or a microtext containing the attributive Спасова рука at my disposal, which is why I am not able to do the positional analysis that would be similar to the one done with relation to the Holy Son. Without any doubt, in the hypothetical prototext, the collocation Спасова рука 
occupied a very strong position, which was reinforced by syllabic and rhythmical means $(\mathbf{v}-\mathbf{- v}-)$.

\section{Preliminary conclusions}

As a result of the reconstruction that was suggested, I was able to detect possible sources of microtext 2 . As a result, the prototext of the incantation under consideration attained a certain lexical and semantic interpretation, typical of incantatory texts. The formulas of 'In the name of...' and 'Spasova ruka...' are contained in the examples I have provided as illustrative material, while the incantation against the evil еуе-волидз with the incipit Спаса-Варука can basically be accepted as an adaptation of the source I have been looking for. Let us have a look at the first part now that there is a number of specific perceptions of the possible content of the prototext.

\section{Microtext 1}

$$
\begin{aligned}
& \text { КуРИЛА МуРА } \\
& \text { ПРоКӦ ЕРМиЛА }
\end{aligned}
$$

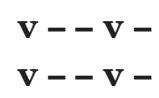

This part of the incantation has a much deeper degree of the semantic ambiguity and, possibly, also some morphological inconsistencies (taking into consideration the existing anthroponyms ПРоКӦ 'Procopius' < ?; ЕРМиЛА 'Yermil' $<$ ? (or 'Yermil Prokopyevich'), which is a result of spontaneous etymological attractions. Any attempts of finding the traces of a prototext in them (? < впрок/ проговорила/, etc.) would carry little conviction. This is why I am going to select another strategy and try to get deeper into the formal organization of this microtext.

The first two lines of the incantation are identical in terms of metrics (dactylic dimeter with a pyrrhic), but at the same time, they are opposed to each other with regard to a number of other parameters. First of all, an apparent morphological mirror-effect of the two lines should be pointed out (if we regard the word ерлила as a verb with ambiguous semantics, the mirror-effect would be syntactic, too): a trisyllabic verb + a disyllabic noun // a disyllabic noun + a trisyllabic noun / quasi verb. This principle of mirror symmetry can also be observed at the phono-rhythmical level: 


\section{Mirror symmetry}

$$
\begin{gathered}
\text { КуРИЛА МуРА } \\
3+2 \\
\text { КР }- \text { МР } \\
\text { РИЛА }- \text { M-P }
\end{gathered}
$$

$\begin{array}{lc}:: & \text { ПРоКӦ ЕРМиЛА } \\ :: & 2+3 \\ :: & P К-P M \\ :: & П Р-\text { РМИЛА }\end{array}$

We can see that a clear mirror-like structure is inherent in microtext 1 , which is why it is absolutely logical to assume that it overlaps with the sound-figurative plan. The phono-semantic analysis, in its current interpretation, is worth separate research (see Mikhalev 2009), and in order to avoid getting stuck in this topic, let us address the existing insights and practices related to it. Since the sequence of sounds in microtext 1 correlates with the overall sound-rhythmical structure of the text one way or another, let us select the sounds with the highest frequency and correlate them with the data concerning universal phonosemantic types (Mikhalev 1995: 86ff.). This is how the frequency cross-section will look: vowel phonemes [U] -3 stressed, [O] -2 stressed +4 unstressed; consonants: [B/P] -4 ; [R] -5 ; [L] - 3; concords: [RL-ML-PL], [KR-MR-PR-JR$\mathrm{BR}$, [RLMR], [JRML].

\section{Possible meanings of phonemes}

\begin{tabular}{|c|c|c|c|}
\hline Phonemes & $\begin{array}{c}\text { Onomatopoeic } \\
\text { meanings }\end{array}$ & $\begin{array}{c}\text { Articulatory- } \\
\text { symbolical } \\
\text { meanings }\end{array}$ & $\begin{array}{c}\text { Synaesthetic } \\
\text { development }\end{array}$ \\
\hline$[\mathrm{O} / \mathrm{U}]$ & howling sounds & round, deep & heavy, dark \\
\hline$[\mathrm{B} / \mathrm{P}]$ & $\begin{array}{c}\text { explosive, } \\
\text { whipping, } \\
\text { gurgling sounds }\end{array}$ & $\begin{array}{c}\text { a stroke, } \\
\text { dimensional, } \\
\text { bloated }\end{array}$ & round, full, vast \\
\hline$[\mathrm{R}]$ & $\begin{array}{c}\text { long trembling } \\
\text { sounds }\end{array}$ & $\begin{array}{c}\text { revolution, } \\
\text { repetitiveness, } \\
\text { tension }\end{array}$ & $\begin{array}{c}\text { round, any kind of } \\
\text { motion in general }\end{array}$ \\
\hline$[\mathrm{L}]$ & long trembling & $\begin{array}{c}\text { lapping up, licking, } \\
\text { liquid }\end{array}$ & pouring \\
\hline
\end{tabular}

Phonemes [U] and [O] occur nine times in the text; five of them are stressed: labial - 'roundness'; the sound is at the back, far (deep) from the entrance 'deep'. The notions of heavy and dark result from the synesthesia with the deep. 
Labial plosives [B/P] occur four times: labialness refers to the notion of roundness (especially in combination with labial vowels); the explosive nature of consonants is perfectly delivered by the onomatopoeic meaning of an explosion, while pushing the lips from each other reminds of a whip; gurgling or boiling can be a variation of the explosion, while puffing out your cheeks before letting the air out can symbolize something that is dimensional, bloated. It should be pointed out here that these sound-figurative parameters could also provoke the transition from $P y K A$ to $P y \Pi A$ and later on to $y \Pi A Л$, reconstructed above.

Vibrant $[R]$ occurs five times: the depiction of long trembling sounds (continuants) is inherent in extremely extensive onomatopoeic resources; the oscillating moves of a tongue symbolize trembling, oscillation; one of the main features of the oscillatory process is a repeated resetting into the initial position, i.e., repetitiveness, coming back, which has been one of the symbolic functions of $[R]$; on the other hand, trembling recalls rolling your tongue against the palate, hence the option of designating a rotating, circular motion and also something round as well as any kind of motion in general; vigorous articulation of the sound with the feature of tension.

Lateral $[\mathrm{L}]$ occurs three times: it is related to the 'liquid' on the basis of the specific motion of the language as an organ of licking and lapping up; in its turn, 'liquid' provides room for symbolizing against such features as pouring, smooth, even, sleek, sticky, slippery, light, etc.

Therefore, the phono-semantic specifications listed above can be joined into a common sound-symbolical image of a circular motion, the rotation of the liquid. And this image matches both the actional level and the metrical and rhythmical structure of the incantation very precisely.

\section{HYPOTHESIS FOR THE GENERATION OF INCANTATORY TEXTS}

The incantatory text has a strictly formalized rhythmical structure. Quantitative and qualitative parameters of this structure are determined by it, and have the harmonious centre and the borders that are consistent with the HC. This is why it is more appropriate to talk not about the structure, but the existence of a specific rhythmical matrix. It is this matrix that is reproduced at different levels of the organization of a word text (sound-rhythmical, syllabic-rhythmical, metrical-rhythmical, etc.) and at the actional level of the incantatory act.

The components of an incantatory prototext, which I have reconstructed, provide evidence of the non-linear nature of its transformation into the final 
text. One part of the incantation (microtext 2) is a combination of the components of the formulas 'In the name of the Father and the Son and the Holy Spirit' and 'Spasova ruka', and it was verified both lexically and syntactically as a sentence originating from the Russian language. The second part of the incantation is a microtext with the deformed lexical and semantic structure (morphological zaum), which is also verified as originating from the Russian language. It seems to be impossible to detect the original components of the source. Within the overall rhythmical matrix, this part correlates all of the levels considered above, except for the lexical-syntactic one. At the phono-semantic level, both parts of the incantation are united by common sound-symbolical meanings, which were generalized into the image of 'a circular motion, the rotation of liquid'; this image matches the actional level of the magical ritual and the rhythmical matrix on the whole.

The lack of semantic coherence with such a rigid formal organization of the text allows to claim with considerable confidence that, basically, there could be no intermediate adaptations between the source of the borrowing (prototext) and the end result. The text would lose its coherence and integrity and fall apart with even the slightest deviation from the matrix. This is why we should be dealing with a one-step, one-time transformation of the prototext into the text that we have at hand. This hypothesis is supported by another important parameter, which is the volume of the incantatory text ( 8 words) that matches the volume of a one-time perception of it (see detailed information in Rabinovich 2010). $7 \pm 2$ of the object is the capacity of a one-time perception of consciousness, the width of the information corridor, or the average capacity of short-term memory of an adult (short-term memory is the memory that is capable of storing information within 25-30 seconds after the cessation of the process of its perception). In linguistics, this capacity is called the Magical Number Seven, Plus or Minus Two, and it determined the maximum number of words in an oral sentence that can be comprehended: when we are listening to someone's speech, we have to lay the words in our heads into a single whole in order to make sense. The number of the chunks within that outlay ranges from 5 to 9 . Only after processing as many units as that, our brain moves on to comprehending the next sentence.

In terms of a one-time effect, the most likely communicative situation here would be a teacher-student scenario: the teacher is reproducing the incantatory act with a prototext, while the student, in view of certain precepts, conceives not the text itself, but some deeper levels of this magical and ritual performative. These levels are clearly related to the rhythmical matrix that I have reconstructed. Some of the parameters of this matrix have not been taken into consideration, since they are unavailable (the rhythmo-melodics of speech, the 
peculiarities of the articulation of sounds, the involvement of the representational stream and media, etc.) In order to achieve the communicative goal, the student must most probably be able to enter (or they are induced by the teacher) into a specific psychophysiological state (altered state of consciousness, perhaps, caused by psychotechnical means), which should activate cognitive processes in the situations when someone is under pressure. At first, the student conceives the rhythm of the incantation, which synchronizes the speech and the actions of the teacher; then the rhythmical matrix 'comes together' in their consciousness, into which the verbal stream is incorporated, and which has been assembled from the components of the source text, 'snatched' by the short-term memory of the student. Apparently the incantation said by the teacher is conceived as a dynamic single whole, from which the matching elements that are either harmonious or resonant with the matrix are singled out. Thus the component that lies at the $\mathrm{HC}$ of the prayer formula 'In the name of...' is incorporated into the HC of the matrix; apparently a certain 'resonating' attribute (in addition to the metrical-rhythmical match) was also inherent in the formula Спасова рука. It can be assumed that the word text is structured from the bottom to the top, i.e., from sound-rhythmical associations to syllabic-rhythmical, morphemerhythmical (morphological similarities are assembled from syllabic-rhythmical associations), lexical-rhythmical (lexical similarities are assembled from morphological matches), and further on to lexical-syntactic. The first part of the text 'freezes' at the level before last, turning into a morphological zaum. It means that once again zaum or beyonsense results from the compression of word material into a rhythmical structure, and, in theory, a new text could correspond to the dominant norms of cohesion and integrity completely.

\section{CONCLUSION}

Apparently this non-linear way of adopting the incantation does not accord with commonly used perceptions of the direct teaching of verbal knowledge and can be interpreted as a special esoteric way of initiation. It is not a mere coincidence that there are typologically close cognitive adaptations of the description of the process of transfer of magical knowledge among the perceptions popular in the Komi folklore, for instance: "Нилкьıв-incantation is transferred, but the last word is not said. And every time it gets shorter and shorter. I don't know, I guess you have to find the word yourself" (Panyukov \& Savel'yeva 1999: 60). Besides, the hypothesis agrees with the facts of the existence of the above-verbal strategic level of incantatory knowledge, which were studied by Adonyeva: 
Competence manifests itself not in the knowledge of ritual texts, but in fluency pertaining to mastering various magical strategies, the fluency that enables you to generate magical utterances of your own, by means of incorporating some additional codes which change the shape of the signs used while performing magical acts. (Adonyeva 2004: 123)

The communicative act I have considered above records the birth of a new verbal and magical register, a new incantation-нилкыв, which matches the psychophysiological parameters of a person being initiated and, apparently, their bioenergy, in view of the initial conditions of 'initiation'.

\section{NOTES}

1 Recorded by Sofia Popova in June 1935. No passport data (National Museum of the Komi Republic: KP-12481. Komi folklore collected by students of the pedagogical college in 1932-1935, p. 143).

${ }^{2}$ With respect to the stress, we are talking about the rhythmical structure of a word, which manifests itself in the text as a specific level of its rhythmo-melodics: "The "lexical" rhythm can be regarded as some kind of prosodic foundation, on top of which the rhythms of higher levels "build up", which are related to syntagmas and sentences' (Kasevich \& Yagunova 2003: 19).

${ }^{3}$ Recorded by E. Osipova from V.P. Larukova, born in the village of Nivsher in Kortkerossky District, Komi Republic, in 1935. Manuscript (National Museum of the Komi Republic: KP-12480. Komi folklore collected by students of the pedagogical college in 1930-1936, p. 37overleaf).

\section{REFERENCES}

Adonyeva 2004 = Adon'eva, Svetlana. Pragmatika fol'klora. [Folklore Pragmatics.] St. Petersburg: Izdatel'stvo Sankt-Peterburgskogo universiteta.

Davydov, Danila 2007. K probleme semantizatsii tekstual'nogo statusa: iz zametok o poeticheskoi zaumi. [To the Problem of Semantization of the Textual Status: From Notes about Poetic Zaum.] In: N. Andreeva \& N. Litvinenko \& N. Pakhsar'ian (eds.) Literatura XX veka: itogi $i$ perspektivy izucheniia. Materialy Piatykh Andreevskikh chtenii: Sbornik nauchnykh statei. Moscow: Ekon-inform, pp. 66-72.

Janecek, Gerald 1996. Zaum: The Transrational Poetry of Russian Futurism. San Diego: San Diego State University Press.

Kasevich \& Yagunova 2003 = Kasevich, Vadim \& Iagunova, Elena. Udarenie i foneticheskoe slovo v russkom iazyke. [Accent and Phonetic Word in Russian.] In: Tamara Erofeeva (ed.) Problemy sotsio- $i$ psikholingvistiki, Vyp. 3. Perm': Permskii universitet, pp. 19-25. Available at http://psychsocling.narod.ru/ kasevich_jagunova.htm, last accessed on 30 May 2019. 
Korbut, Aleksandra 2005. Tekstosimmetrika kak razdel obshchei teorii teksta. [Text Symmetrics as a Section of the General Theory of the Text.] Avtoreferat dissertatsii na soiskanie uchenoi stepeni doktora filologicheskikh nauk. Barnaul: Altaiskii Gosudarstvennyi universitet. Available at http://www.dslib.net/jazyko-znanie/ tekstosimmetrika-kak-razdel-obwej-teorii-teksta.html, last accessed on 30 May 2019.

Lytkin \& Gulyaev 1999 = Lytkin, Vasilii \& Guliaev, Evgenii. Kratkii etimologicheskii slovar' komi iazyka. [The Concise Etymological Dictionary of the Komi Language.] Syktyvkar: Komi knizhnoe izdatel'stvo.

Mikhalev, Andrei 1995. Teoriia fonosemanticheskogo polia. [Theory of the Phonosemantic Field.] Piatigorsk: Izdatel'stvo PGLU. Available at http://liconism.ru/bibliotekalibrary/298, last accessed on 30 May 2019.

Mikhalev, Andrei 2009. Sovremennoe sostoianie fonosemantiki. [The Current State of Phonosemantics.] Novye idei v lingvistike XXI veka. Materialy 1 Mezhdunarodnoi nauchnoi konferentsii, posviashchennoi pamiati professora V. A. Khomiakova. Vol. 1. Pyatigorsk: n.p., pp. 52-59.

Moskalchuk, Galina 1998. Dinamika formy teksta. [Dynamics of the Text Form.] Iazykovaia kartina mira: lingvisticheskii i kul'turologicheskii aspekty. Vol. 2. Biysk: Biiskii Gosudarstvennyi pedagogicheskii institut, pp. 22-26.

Moskalchuk, Galina 2003. Struktura teksta kak sinergeticheskii protsess. [Structure of the Text as a Synergetic Process.] Moscow: URSS.

Nalimov, Vasily 1908. Kansatieteellisiä kirjoituksia ja muistiinpanoja syrjääneistä: Venäjäksi. Suomalais-Ugrilaisen Seuran Arkisto, I. 39. Helsinki.

Panyukov 2010 = Paniukov, Anatolii. $K$ voprosu o samoorganizatsii zaumi (na materiale komi schitalok). [To the Question of Self-Organization of the Zaum (on the Material of the Komi Counting Rhymes).] Vestnik Cheliabinskogo gosudarstvennogo universiteta, No. 34 (215). Filologiia. Iskusstvovedenie. Vyp. 49, pp. 93-98.

Panyukov \& Savel'yeva 1999 = Paniukov, Anatolii \& Savel'eva, Galina (comps.) Traditsionnaia kul'tura komi: Etnografiia detstva. [Traditional Culture of the Komi: Childhood Ethnography.] Materialy fol'klorno-etnograficheskikh ekspeditsii 1995-1998 gg. Syktyvkar: Gosudarstvennyi tsentr narodnogo tvorchestva Ministerstva kul'tury Respubliki Komi.

Rabinovich, Mikhail 2010. Operativnaia pamiat' i chislo sem'. [Operative Memory and the Number Seven.] Nauka i zhizn', No. 8. Available at http://www.nkj.ru/archive/ articles/18456/, last accessed on 30 May 2019.

Shlyakhova 2006 = Shliakhova, Svetlana. Fonosemanticheskie marginalii v russkoi rechi . [Phonosemantic Marginalias in the Russian Speech.] Avtoreferat dissertatsii na soiskanie uchenoi stepeni doktora filologicheskikh nauk. Perm': Permskii Gosudarstvennyi pedagogicheskii universitet. Available at http://liconism.ru/ biblioteka-library/254, last accessed on 30 May 2019.

Sidorov, Aleksei 1997 [1928]. Znakharstvo, koldovstvo i porcha u narodov komi. Materialy po psikhologii koldovstva. [Folk Healing, Magic and Witchcraft among the Komi People: Materials of the Psychology of Magic.] St. Petersburg: Aleteiia.

Ulyashev 1999 = Uliashev, Oleg. Nimkyv. [Incantation.] In: Anna-Leena Siikala \& Vladimir Napol'skih \& Mihály Hoppál (eds.) Entsiklopediia ural'skikh mifologii. T. I. Mifologiia komi. Moscow \& Syktyvkar: DIK, pp. 256-258. Available at https:// www.academia.edu/8463469/, last accessed on 30 May 2019. 
Vinogradova, Liudmila 2002. Ta voda, kotoraia... (Priznaki, opredeliaiushchie magicheskie svoistva vody). [The Water That... (The Signs Defining Magic Properties of Water).] In: Svetlana Tolstaia (ed.) Priznakovoe prostranstvo kul'tury. Moscow: Indrik, pp. 32-60. Available at https://inslav.ru/images/stories/pdf/2002_Priznakovoe_ prostranstvo_kultury.pdf, last accessed on 30 May 2019. 


\title{
ASPECTS OF STUDYING THE VERBAL LEVEL OF CATTLE-BREEDING RITUALS
}

\author{
Liudmila Lobanova \\ Research Fellow \\ Department of Folklore, Institute of Language, Literature, and History \\ Komi Science Centre, Russian Academy of Sciences, Russia \\ Email: sergejluda@mail.ru
}

\begin{abstract}
This article contains an analysis of a verbal component of cattlebreeding rituals. In terms of their genre, incantatory texts are divided into five different categories: sorcery, ritual dialogues, incantations, lamentations, and prayers, out of which the most widespread is sorcery. As a result of a structuralsemantic analysis of sorcery, two types of texts have been singled out. Sorcery with a closed structure consists of two parts, and its parts can be related as opposition or comparison. Sorcery with an open structure is divided with respect to its recipients: animals, saints, and the domovo $i^{1}$.
\end{abstract}

Keywords: incantations, Komi cattle-breeding tradition, lamentations, sorcery

\section{KOMI CATTLE-BREEDING TRADITION}

In the traditional Komi household, hunting and fishing were supplemented by cattle-breeding and agriculture, and the former was an essential prerequisite for the development of the latter: cattle were bred for manure, without which the scanty local soil was unsuitable for growing crops. In the conditions of the extreme north, where the indoor season makes up 7-8 months, cattle-breeding was a labour-intensive process, limited by the total surface area of grasslands and pastures. Traditionally, stock-rearing for the purposes of producing dairy products for personal consumption was very popular, while horses were bred for their draught power and as a means of transport, and sheep for their wool. For keeping cattle, special outbuildings were built (гид, шьь, карта, гидня 'cattle barn'), which were integrated into a residential compound: a warm one for cows and cold one for sheep and horses (see Fig. 1-4). Cattle grazed for 4-5 months, being pastured without any supervision, and in a number of traditions, cattle would be sent out to summer pastures. Until the 1930s, the livestock number in households, depending on the size of the family and the total surface area 
of grassland owned, amounted to 1-10 cows, 1-3 horses, and 3-15 sheep. After the introduction of collective property, the livestock population at individual farmsteads decreased. An increase in the livestock population of the cattle stock was observed in the $1990 \mathrm{~s}$, and in the recent decade there has been a sharp decline that is related to economic conditions and the agricultural situation in the country as a whole.
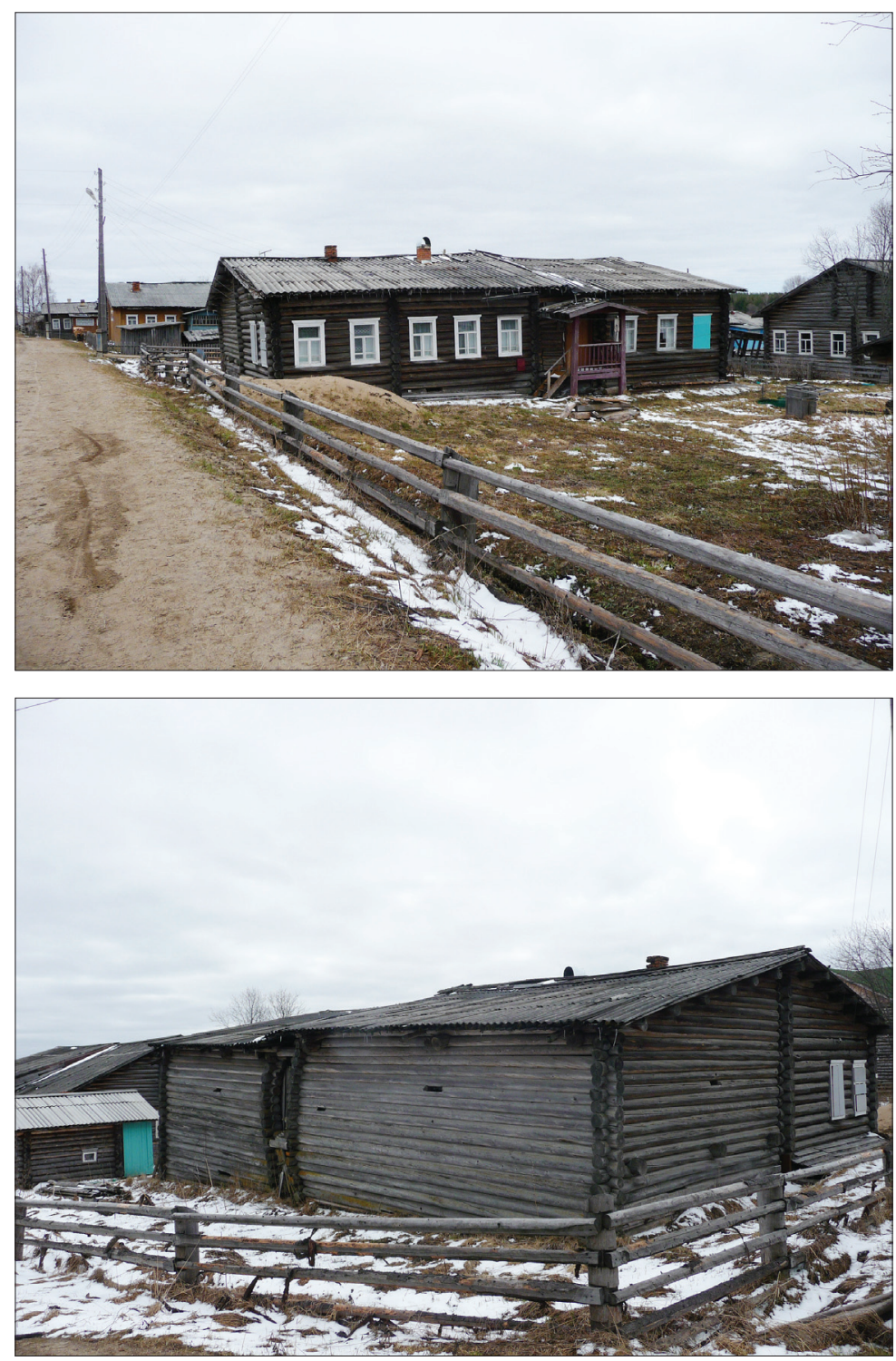

Figure 1-2. A particular type of house-yard in the south-eastern part of the Komi Republic (front and back views). Under one slope of the roof, there is the living space; under the other one, the utility space. On the lower level, there are cattle barns. Village of Nivshera, Kortkerossky District. Photograph by Liudmila Lobanova 2014. 

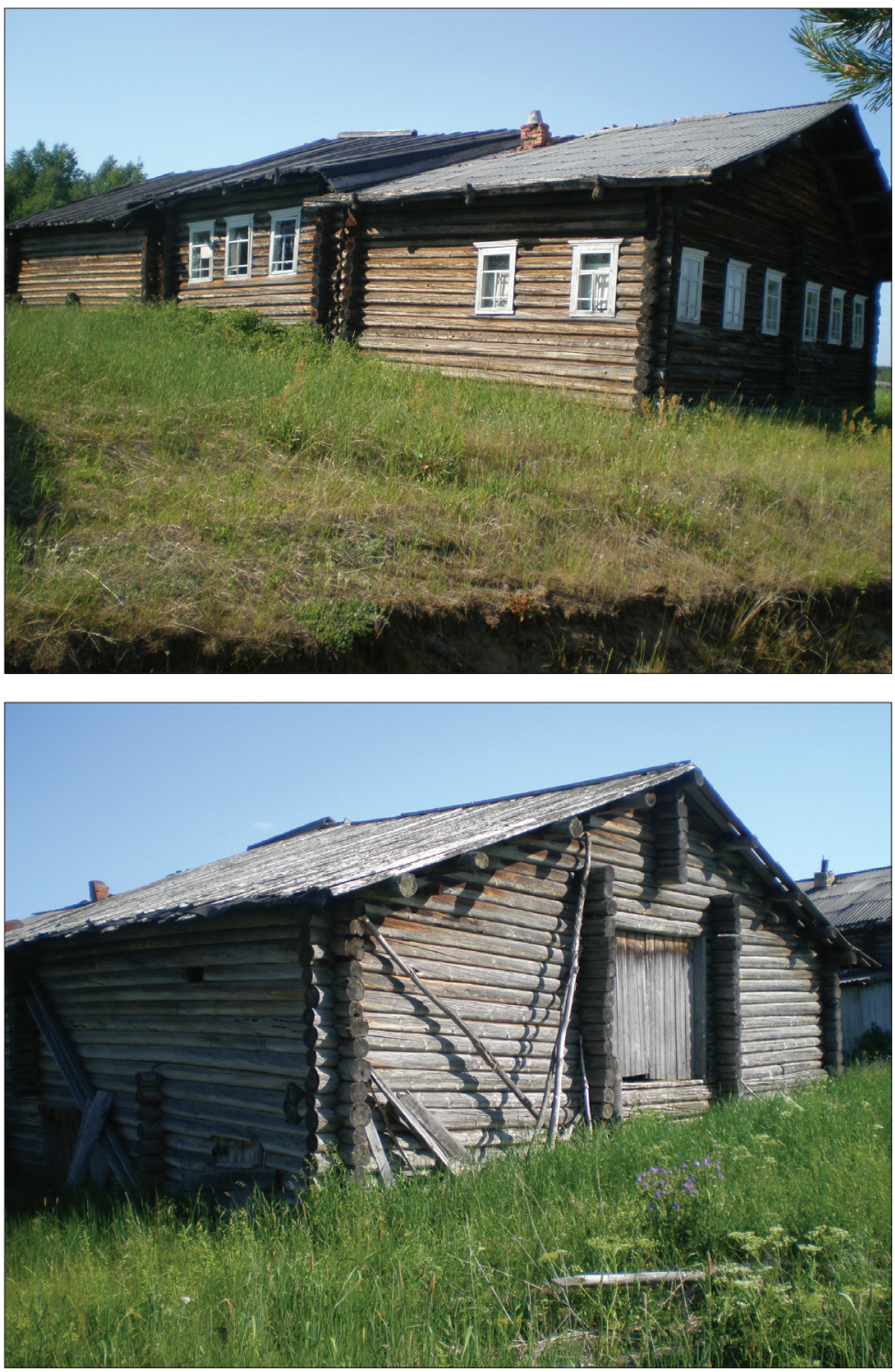

Figure 3-4. A particular type of house-yard in the western part of the Komi Republic (front and back view). The utility part is in the background; premises for cattle are on the lower level of the utility space and in the underground of the middle izba (cabin). In the background, there is a log ramp for carting hay. Village of Körttuvya, Udorsky District. Photograph by Liudmila Lobanova 2011.

In terms of spiritual culture, cattle-breeding was represented by a set of rituals, beliefs, legends, superstitions, prescriptions, bans, magical techniques, incantatory texts, etc., and on the whole, it is a ritualized activity. All of the actions pertaining to cattle management, even the most utilitarian and routine, can attain magical interpretation. 
Cattle-breeding as a branch of traditional activities requires the mastery of not only a number of practical skills related to cattle management, but also the acquiring of certain knowledge that is popularly referred to as cкӧт гӧгӧp möдӧ. 'knowledge about (literally 'around') cattle'. The mastering of such knowledge takes place after a change in social status, i.e., when a girl gets married, starts a family and a household, and becomes the mistress of the house. Most often the 'knowledge about cattle' (sometimes it is more specific, for instance, мӧс гӧгӧр тӧднь 'to know about (literally 'around') a cow' involves mastering protective, productive, and remedial magic, including completing some ritual actions and saying incantatory texts: ${ }^{2}$

Пӧрысьясыд ёна скӧттӧ видзлісны и меньлм тоже передайтэлась, и ме скӧтӧн же ола. Зэв унатор висьтавліснь, кор ме ичӧт на вӧлі, и зэв унатор кььвлі. Миян ьцжыл мамыс вӧлі шуӧ, ӧти женшина миян татӧн вӧлӧла мӧс

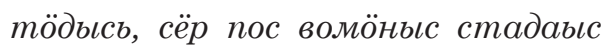
ставнас миянладорьсь вӧлі мунӧ нелямын кьлмын мӧс, и если кӧ пе ме ӧні кӧсъя, шува пе кутшелке кьь, и став мӧскьс пе татчи пласьт усяс, мыцйла пӧ мӧс гӧгӧрысс нинӧм оз тӧдны, некутшем молитва пӧ лӧскьсль абу льљделаэсь. Ме пӧ ӧні пӧрьцсь нин, да сійес ог нин вӧч. И вот, значит, лии, ӧнія йӧз, молитваяссэ лӧс гӧгӧрьс нинӧл ог тӧдӧй, сьє вӧсна верласньц тӧдьєсь да кужььсь йӧз лӧстӧ весиг висьлӧдны. ${ }^{3}$
Elderly people would keep lots of cattle, and they handed it over to me. I also breed cattle. They would say many different things when I was little. I heard many stories. My grandmother said that there had been a woman here who had magic knowledge of cows. Once when a herd of cattle, about forty cows, was crossing the bridge, she said that if she wanted she could say a word that would make the cows lie down flat, because [their owners] did not know anything about the cows, they had not said any prayers. But then she added that she was too old for that and would not do so. It means that we, the people of the present, do not know any prayers for our cattle, and those who know them and are able to use them can call illnesses upon the cattle.

The lack of such knowledge, an unusual or a more serious case, can lead to the need for turning to the sorcerer for help, whose knowledge, among other things, is determined by knowing incantatory words, i.e., нuлкь८ ${ }^{4}$, which is also reflected in the name of such people, i.e., нилкьв видзысь, ныллкьвьл, нилкыє кутьль 'incantation keeper', who are ascribed with the abilities both to treat animals and to bedevil them. 
(Висьтавлісны, мыьй Саввӧыс (They said that Savva could bedevil тшыкӧдлӧла мортӧс ли скӧтӧс?) a person or cattle?) Yes, they say Но так сія пӧ ёна тшыкӧдчылӧла. he bedevilled many people. He was Ciя ачьı пӧ ошйьсьӧл. Me nӧ boasting about that. He said that he асьлнас пӧ чечча, кьлльӥ вылӥ would wake up in the morning and nе пета, нилкылсӧ пӧ лэдза, go out to the front porch, and send an и тӧлнас пӧ кьччи нуӧ (а сэн Кось incantation, and the wind would blow саяс яг, Вайлиос яг, сэн Вайлӧс-ю, it away (there is a forest behind the но и Вайлӧс ягӧн шуӧнь, сэсся village of Kos, the Vaimös Forest, there пӧ меял нилкылйьс), тӧлнас is the Vaimös River, and the forest нилкьлсӧ тӧлзьӧдо̆, кутшиол пуӧ is also called Vaimös), and the wind веськалӧ, сія пуыс косьлй. Сія пӧ would take the incantation into the ошйысьӧ, Косьватас пӧ Лихачевка forest, and if it hit a tree, it dried out. ватасыс, став пӧ леял поньсь кос He was boasting that all of the people пессӧ сотӧ, кос кондасӧ, сія пӧ nуыс living in the vicinity of Likhachevka косьлӧ, сія сэсся пес вылӧ ваялӧны, were burning dry wood and deadwood менал понысь пӧ ставыс Лихачевка because of him, because the trees were ватасыс пессӧ сотӧны. ${ }^{5}$

drying out, and then they would cut them into firewood. He said that all of the inhabitants of Likhachevka were heating up their houses with his firewood.

\section{SPECIFICATIONS OF SOURCES}

This research is mainly based on field materials, recorded in the form of interviews with the carriers of the tradition on different topics related to the cattlebreeding tradition (cattle maintenance and management). In terms of content, the records are not observations of actual rituals (recording the ritual practice at the moment of its actualization), but oral descriptions of rituals (what people usually do when they let the cattle out to pasture), specific anecdotal evidence (how they treated a cow with a swollen udder, or how they brought a cow which had just been bought into a cowshed), memories, stories, edifications, etc. ${ }^{6}$ Without any doubt, a perfect option would have been observing a ritual and recording it at the moment of its actualization, but under the conditions of folkloric-ethnographic fieldwork, researchers rarely have a chance to witness and record actual ritual practice. 
Material of this kind was also found in archival manuscripts, ${ }^{7}$ in published linguistic and folkloric material (see Uotila 2006; Rédei 1978), and in research concerning the studies of magical representations and incantatory texts (see Vetoshkina 1982; Kudryashova 1991; Sidorov 1997 [1928]). In addition to that, a considerable part of the material is represented in the form of incantatory texts, selected from the handwritten notebooks of informants.

When the material is recorded this way, it is impossible to differentiate between cattle-breeding rituals using the principle of existence or absence of the verbal level and study the variation of texts. At the same time, this format allows to analyse the context of the existence of incantatory texts and popular perceptions of the role played by a word.

\section{THE PROBLEM OF DISTINGUISHING THE VERBAL COMPONENT}

The majority of the material was recorded in the form of interviews, in which informants spoke about a ritual and described actions and events, while the verbal component would recede into the background. This was furthered by the type of a speech act itself as well as by the questions asked by the collector: What would you do if a cow did not give milk? How did you let cattle to pasture for the first time? This is why quite often additional questions had to be asked about the verbal component of a ritual.

(Кьљзи лӧстӧ лудад ледводдзаьсь лэдзан?) Сійес вот лӧстэ лэдзан, наприлер, тульснас лэдзан первой после зиль, значит, миян сійе тоже, ог тӧд, коді висьталіс бабйес ли, сиктсаясыс ли, тоже менал прилета. Кор лиоскыс петэ, бӧрбя коктуйяссэ ме гидйас бӧр шыбита, мед тӧдны горт мӧдас. Сійа муас коле коктуйьс, и сійе мусэ, мед и куйедас шагнитас, куйедсэ сійес гидйас бӧр шыљита. (Мыци шувад?) Кьљзи коктуйьљ сэн олэ, сідз же мед вӧлілоктэла татче. Ас кьвъеснад, вед дзик же сідз, ас кьвъесэн cоставитэла. ${ }^{8}$
(How do you let a cow to pasture for the first time?) When you let a cow to pasture for the first time, after winter, in spring, well, I don't know who told me about that, grannies or home folk, but there is a superstition. When a cow leaves the cowshed, I throw the last mark of a trail back into the cowshed, so that it will know where its house is. Because this mark of a trail is in the soil, or in manure, and I throw that manure back into the cowshed. (What do you say when you do that?) Your trail goes to the cowshed, and you should come back to the cowshed. I say it in my own words, because I always say it in my own words. 
Вербасӧ ваян, а Ёгорей луннас нин You bring pussy willow in, and on сійӧс [скӧтсӧ] лэдзӧны видз выллӧ, George's Day they let them [the catи сійӧн сійӧс швачӧдӧны вербанас. tle] out into the pasture, and they whip (Мьцикӧ шуалӧньє) а "Ёгор- them with pussy willow. (What do they батюшко, скӧтӧс видз-хранит” - say?) 'Father George, save and protect тадзи, а ме сэсся ог тӧд. ${ }^{9}$ the cattle', something like that, I don't know anything else.

In the majority of cases, incantatory texts would be perfectly incorporated into the stories of informants and described along with the actions. It was introduced with the help of a speech verb in direct or indirect speech, pointing at the synchronism of a word and action, and also less frequently at their sequence. For instance:

Ветльь лися кладбищео̆, боссь Go to the cemetery and take a chip, кладбищесьыс щепка, пу щепка. a wooden chip. When you come back, Локтан да мьиикӧ гид белляс вӧч make a hole in the cowshed door post, розь, да щепкасӧ сэтчӧ, шуан: [hammer] the chip into the hole and "Кьљз тая щепкасӧ тувъялі да оз say: 'I have hammered the chip into вӧрзьь, сідзжӧ мӧскьсльсь меял the hole, and no one will touch it, and мед нелтор оз ворзьӧд. '10 nothing will happen to my cow.'

(А мӧскьдлӧн кутшӧм праздникысе) Ог тӧд. А вӧӧ тай, шуасны, тувсов Ёгорей лун, шестое маянад. Ciйе пе вӧвлӧн праздник, вӧвьясэс йиреднь лэдзласны. Тошнад пе, Егорей-батюшко, йиред вӧӧястэ. Егорейыс ли мый ли йиредэ ли мыцй ли. Сідз тай вӧлі шуласньь. (Вӧвтэ лэдзиген шувасньь?) Да. ${ }^{11}$

(What festival do cows have?) I don't know. They said that the horses' day was George's Day in spring, on the sixth of May. It was a day when horses were let out to pasture. Father George, feed horses with your beard. George was supposed to feed them. This is what they said. (Did they say that while letting the horses out?) Yes.

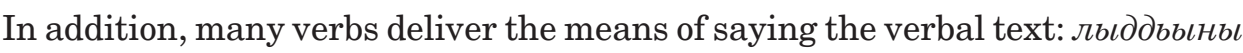
'to read, reread, enumerate', горӧдчьны, горзыньь, горзыцтавны 'to call out, to shout', шӧпкӧдны 'to whisper'. For instance:

"Гортӧ локтӧ, тайтӧ, лок, тайтӧ- 'Come home, cows, come home! Do not тайтӧ. Лёкъясль эн сетчӧ, некодль succumb to bad people, do not succumb эн сетчь. Кӧинбяс, лёк йӧз лед тэд to anyone. Let wolves and evil people оз мешайтны. Места тӧд, места not disturb you. Know your place, тӧд!” Тадзи горзіснь Ыджьљ know your place!' They used to shout Четвергад пач трубаад. ${ }^{12}$ it into a chimney on Holy Thursday. 
In the stories of some performers different nominative names also surface, such as кьєвъяс 'words', нилкьв 'invocation', прилета 'superstition', загӧвӧр 'incantation', молитва 'prayer', which are used as synonyms for designating an incantatory text. Additionally, incantatory texts can be named by the targeted object, for example, висьӧльсь 'from a disease', тшькӧдӧлььсь 'from blight', волидзысь 'from the evil eye', eliminating or getting rid of what the text is aimed at. In this case such names as cкömbıcb 'for (literally 'from') the cattle', лӧскысь 'for (literally 'from') a соw', лӥс локтӧлысь 'for (literally 'from') the cow coming back', which come up in the analogies listed above, on the basis of a ready-made language form, are of particular interest, and informants do not ponder on their meaning:

“Святые священнолученики, Власия, молите бога о нас”. Тайӧ скӧтысь молитва. Скӧтыд мыйке лоэ, да тайе лолитчены. ${ }^{13}$

'Holy martyrs, Vlasia, pray to God for us.' This is a prayer for (literally 'from') the cattle. They pray this way so that nothing bad would happen to the cattle.

Quite often incantatory texts are named after a Christian saint who is the addressee of the prayer, and also by the first word or the main motif of the text, which primarily helps to keep the text in the memory of the performer. For instance:

(Кор первойьıсь скӧттӧ лудӧ лэдзан, мый вӧчан?) Но кутшӧлкӧ лолитва льљдян “Вӧскреснӧй лолитва”, сэсся Ёгорей, шестое, сэн кутшӧлкӧ молитва выйылм да, выйыл, выйылм, дул выллӧ оз усь, сразу дул вылӧ оз усь. Егорейьслӧн на выцйылм кутшӧлкӧ молитва ... "Христос c тобой Егорий храбрый, прили мою животину на всё полное лето u cnacu ux!'14

Сэки кресталэны ӧдзестэ, водзджык идрасясны, и кресталэны вӧлэл зӧлӧтэй толанэн пе. "Кристос печать, йигно-толно зӧлӧтӧй толаннад, зӧлӧтэй ключнад." Карта ӧдзестэ тадзи кресталэны да шувалэны. ${ }^{16}$
(What do they do when they let the cattle out to pasture for the first time?) Then you should say some kind of prayer, for instance, a Sunday prayer ${ }^{15}$, then George, on the sixth, there is also a prayer of some kind, there definitely is, but I can't think of it right now. There is another prayer addressing George: [what follows is the text of the original prayer] ... 'Let Christ be with you, you brave George, take my cattle for the whole summer and protect them!'

Then they would criss-cross doors, handle the cattle and criss-cross the cattle with a 'golden lock', like 'Christ's seal, close it down with a golden lock, a golden key'. This is what they say while criss-crossing the doors of the cowshed. 


\section{GENRE VARIETIES}

Incantatory texts that function within cattle-breeding rituals can be divided into five categories: sorcery, ritual dialogues, incantations, lamentations, and prayers. In terms of the latter, I mean canonical prayers that are said within cattle-breeding rituals (see the text cited above as an example). I will discuss them in detail below.

The main problem consists in distinguishing between sorcery and incantations, since the same texts are referred to as sorcery in one group of studies and as incantations in another. In Russian folklore studies, the trend is the following. If an incantation is used in the meaning of an 'incantatory text' and means a verbal means of magical impact, sorcery is not distinguished. When distinguishing between incantations and sorcery, a number of attributes that specify them as oppositions are used as a basis: dimensional texts with a complex structure and a carefully structured composition vs. short verbal statements; incantations prevail over action vs. sorceries are secondary, producible, dependent on the action; belong to the professional environment, arcane knowledge, sacral persons vs. common household knowledge; a part of a special ritual vs. being a part of practical ritual actions. However, when turning to some specific folklore material, categories become blurred, some transitional forms appear, and researchers tend to use one common term, which is 'incantations' (Fedosova 2007). In the current article, sorcery and incantations are regarded not as oppositions, but as different forms and means of verbal and magical impact, which can be singled out on the basis of the material related to the Komi cattle-breeding tradition. But we should specify right away that the list of genre variations provided above does not include all possible variations, since there are texts with unidentified particular genre characteristics (when the text is divorced from some ritual context) as well as transitional and contaminated forms.

\section{Sorcery}

The largest part of recorded texts are defined as sorcery, i.e., short verbal formulas that accompany various practical activities aimed at keeping and managing cattle (shearing sheep, milking cows, letting the cattle to pasture, etc.), communicating the ritual and magical function to the utilitarian practice, or being a part of a special ritual which accomplishes a producing and apotropaic function (cows are whipped with pussy willow branches for good health; milk is criss-crossed to protect it from bewitchment, etc.). 
First of all, there is sorcery expressed in interjections. They are included in a category of imperative interjections (will expressions) and used for calling an animal to behave in a certain way or stop doing something. In some cases, vocative interjections, which are used to call or drive animals away, are distinguished into a separate group (Popova 2000: 522).

Тӧлӧ (dial. тӧлэ) (SSKZD 1961: 375) is a call to a cow while milking it, which expresses the order to stop moving and stand still. The etymology of the word is unclear, and it might originate from the word ӧлӧднь 'to stop, calm down'.

Taŭmö (dial. maŭmə, mamьö) is a call to the cow, addressing the cow (SSKZD 1961: 363), mainly used to call the cows to come back home from the pasture, and this is what cattle owners say while driving cows into a shed. The etymology is unclear: there might be a relation to adverbs, pronouns, and particles with emphatic-intensifying and demonstrative semantics: maüö 'this one', mamчӥ 'over here', maŭ 'right here'. ${ }^{17}$

Вала-вала is an exclamation used to call cows to a watering place (Zhilina 1975: 161).

Tnpy is an exclamation used to stop a horse while driving it, or they would shout it trying to calm the horse down, while approaching or examining it.

Öcbm-öcbm (dial. möcb-möcb, öcbmö-öcbmö, öcbma-öcbma) is an exclamation used to call sheep (SSKZD 1961: 267). The etymology is unclear. In modern speech in similar cases the particle баль-баль is most commonly used; it is a derivative from бале 'a lamb'.

Calves and bull-calves are called with mnрутьӧ-тпрутьӧ (dial. mnрутиmпрути, тnруте-тпруте, пруть-пруть) and конь-конь (dial. коне-коне). In the last adaptation, at the suggestion of linguists, the common Permic stem *kon' 'a calf' is preserved (Lytkin \& Gulyaev 1999 [1970]: 133). Foals are called with an exclamation чиб-чиб (dial. чибӧ-чибӧ, чибе-чибе) (SSKZD 1961: 410), which is a derivative from a word чибӧ 'a foal'. Some of the interjections come across in the form of addresses in incantatory texts and will be described below.

Sorcery mainly consists of a single statement and is structured according to the model of directives, using imperative verb forms. On the basis of modern material, the overview of which is provided above, no specific popular name for such statements can be singled out. In earlier records of this kind, verbal and ritual actions were referred to as вордчьнь: 
Сәсся вӧлі ьюж шыриген вордчень. They would foretell while shearing Ыжюе шыраснь да вурунсэ бось- sheep. They would shear a sheep, take таснь киас да шуалэны, зыралэнь с wool in their hands and say things, rub миьш вывсэ и былэн да шуэны: it on the sheep's back and say:

Кӧчен мун,

Сюзен лок.

Кӧин кулальи ин шедэдчь, Go away as a rabbit, Come back as an owl.

Потшыс коласэ юртэ ин сюй, Ассььљ кӧзяин-кӧзяйкатэ тӧд, Гортэ волььвль. ${ }^{18}$

Don't get caught by a wolf,

Don't stick your head between thin poles, Know your master, Come back home.

The verb ворднь in the Komi language often comes across as a dialectal adaptation of the verbs синь 'wish, predetermine', and тунавны 'predict, foretell' (SSKZD 1961: 60, 337, 381), and it can also be used in the meaning 'to charm, to tell one's fortune'. Unlike dialectal adaptations, etymologically this verb originates from the word вор 'faculty of speech' (Lytkin \& Gulyaev 1999 [1970]: 63), which is why вордчьциь can be translated as 'to foretell'. In spite of the fact that this function is not expressed in modern recordings, it sticks to similar verbal-magical acts. Their purpose is to speak out the desired course of events, the expected outcome. These texts are accompanied by a number of certain actions of practical or magical nature, which is why we define them as sorcery.

In spite of a large diversity of sorcery, two structural types can be singled out. At the basis of sorcery with a closed structure ${ }^{19}$ (self-contained phrasal utterances - Grigory Permyakov (1988: 95); incantatory formulas - Valentina Kharitonova (1992: 3-37)) lie clichés consisting of two parts that can be related in the following way:

- Oppositions: 'Go away as a rabbit, come back as an owl', in which predicates (go away - come) and objects (rabbit - owl) are in opposition, whereas rabbit and owl are in opposition on the grounds of their level of fluffiness ${ }^{20}$ : a rabbit has short and thin fur, while the feathers of an owl are long and thick. Also, for example, the sorcery of Бӧр туйсэ вунэд, водз туйсэ вӧт ${ }^{21}$ 'Forget the road back, think of the road ahead', which is said when driving a cow that has just been bought into a cowshed. These statements are metaphorical. - Comparisons, in which the first part of the text (how..., where...) describes the original ritual situation and actualizes the required attribute, and in the second part, the desired situation is simulated:

Кьљз тая щепкасӧ тувъялі да оз вӧрзьь, сідзжӧ мӧскысльсь меял мед нелтор оз ворзьӧд. ${ }^{22}$

[I] have hammered the chip into the hole, and nothing will happen to my cow. 
Кьљзи тая саис лэбзяс да ьылла воше, мед менал вӧл вылісь тадзи же лэбзяс волидзис!

Just like this ash is scattered and disappears into thin air, let the evil eye be removed from my horse (Uotila 2006: 312).

Матёнка Туся, кӧн тэнад бурсиьљ да бӧжьљ, сэтӧн мед тэнад войсӧ телӧьд. ${ }^{23}$

Matyonka Tusya (literally 'a little berry'), where your mane and tail are, that is where your body [will be] at night.

The sorcery that was performed in the form of ritual motivations has also been included in this group.

Трӧича рос тоже вӧлэл пьртэнь Тree branches picked at Pentecost керкаэ ен доре, лӧсъястэ на were taken back home and put near вачкылэны, лед пе трӧича рос кодь the icons, and cows were whipped with здоровеесь лоанныц. ${ }^{24}$ them so that they would be as healthy and vigorous as Pentecost tree branches.

Мед берба-баля кодь здоровейесь So that you would be as healthy as мед, зӧлӧтаяс, лованньљ.. ${ }^{25}$ pussy willow catkins, my darlings.

Another type is the sorcery with an open structure (non-self-contained phrasal utterances in Permyakov 1988). The sorcery of this kind can be grouped according to addressees. In the first group of sorcery, the addressees are animals. Below you can see some examples of sorcery from different sources said while shearing sheep, which show the open-type structure of such texts, i.e., from short paroemia to the statements that contain addressees and enumerations:

Ыэлль тотшкӧны юрас шыригас: “Шьцран кад тӧд."

Кӧзяйкаяс, кор шырӧны ью, то сэк шуалӧны: "Ӧсьт-ӧсьт / шыран кад тӧд / кӧйинльь эн сетчьь / кӧрт потшӧс волӧн звирк четчышт / гоз баля вай. '27

Ыэж шыриген: “Ӧсьт-ӧсьт / шыранкад тӧд / Ёма-бабалі эн сеччи / бӧр гортэ лок / эн сечи!'”8
A sheep is tapped on its head while being sheared: 'Know the right time for shearing.'

When shearing sheep, women would say: 'Sheep, sheep, know the right time for shearing, don't get caught by a wolf, jump over the iron fence, give birth to a couple of lambs.'

When shearing sheep: 'Sheep, sheep, know the right time for shearing, don't get caught by Baba Yaga, come back home, don't get caught.' 
(Шыцигас нинэм оз вӧлі шуавнье?) A вед нинэл, шыригас только шыран воропен колскебта, Агниес тшӧкта же "Шыран кад тӧд / кӧрт потшысэд чеччышт / лёк Ёмальь эн сетчи.'

Шырнызаводитігас юрас таркедэнь шыраннас. "Пась кодь яя / сюръя кодь нэла / кӧртэн-пуртэн вийтэг / эн кув. 'эо
(Weren't they saying anything while shearing?) Nothing, I just tap their heads with the handle of the scissors after I have finished, and I make Agnia [daughter] do that, too: 'Know the right time for shearing, jump over the iron fence, don't get caught by Baba Yaga.'

At the beginning of shearing, they tap [a sheep] on the head with scissors. 'Be as furry as a fur coat, as long-lived as a column, don't be butchered with ironknife, don't die.'

The sorcery cited above, which was performed while shearing sheep, communicates the model of animal behaviour, on the basis of which the practical meaning of the ritual can be singled out, i.e., to keep the animal alive until the next shearing ('know the right time for shearing', 'jump over the iron fence / the hedge with seven stack stands', 'don't get caught by Baba Yoma'31, 'don't get stuck between thin poles', 'don't get caught by a dog', 'be as long-lived as a column', 'don't be butchered with an iron knife', 'don't die'), to improve its functional characteristics, in particular, its woolliness ('know the right time for shearing', 'bring good wool to your master'), and fertility ('give birth to a couple of lambs').

A peculiar feature of sorcery performed on animals is the match of the addressee and the recipient. It can be noticed that in the majority of cases, both the addressee and the recipient are omitted at the verbal level, but an emphasis is placed on them through the action that either precedes or accompanies the text. In our examples, a sheep is tapped on its head with scissors. And only two texts contain the exclamation öcbm-öcbm, used to call sheep. At the same time, the sorcery that accompanies ritual actions connected with cows was always marked by the name and colour of the animal with such additions as матушка, матёнка 'mother', рабича божья 'servant of God', which represent a respectful attitude to the cow and its position in the household, on the one hand, and ritual speech, on the other hand:

Бласлӧ Кристос, Лунашка-матушка, давай эн сетчы скӧтльь, этӧ лёк йӧз вылио, эн веськав, лючки. ${ }^{32}$

Bless us, Christ, mother Lunashka (literally 'Day, Little Day'), don't get caught by an animal, don't get caught by bad people, [let things come] right. 
The addressees of other kinds of sorcery are the Christian saints George, Blaise, Haralampus, Modest, Anastasia, Florus, and Laurus, who act as protectors and guardians of cattle and cattle-breeding in popular perceptions, and are sometimes referred to as the 'cattle gods', while their commemorative days are called вӧв праздник 'horse day', вӧв ниллун 'horse name day', лиосль лолебен $л у н$ 'cow prayer service day', etc. Sorcery of this kind can contain the following elements: an address, the kernel form, a recipient, and enumerations.

Ёгор-батюшко, скӧтӧс видз-хранит. ${ }^{33}$

Father George, save and protect my cattle.

Святы Ласей, святы Настасья, святы Модес, святы Харлалпия! Видзей да бережитэй ленсьылм Милка-матушкаэс став лёксьыс,

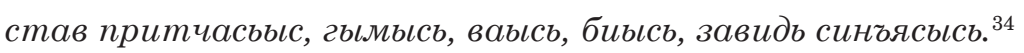

Saint Blaise, Saint Anastasia, Saint Modest, Saint Haralampus! Save and protect our mother Milka from anything bad, from any kind of evil, disaster, thunder, water, fire, or evil eye.

Господи благослови, святый Уласей! Сохрани и бережи от всяких хишных зверей и от зльх людей.

Bless me, oh, Lord! Oh, Saint Blaise! Protect the cattle from wild animals and evil people. ${ }^{35}$

Визюк ли Серед матушкаль, Господе, сет здоровье, избавит лёк йӧзысь, лёкьсь-притчась, ьљжжыд милӧстьнад. ${ }^{36}$

Vizyuk or Sered (literally 'Spotty, Black and White'), oh, Lord, bless the mother, save her from evil people, from bad and evil, at your greatest mercy.

The addressee of the third group of sorcery is the mythological character of the domovoi. In the popular view, the domovoi takes care of the well-being and fertility of the inhabitants of the cowshed, but it can also do damage to cattle if norms or rules are violated. As a rule, sorcery connected with the domovoi is performed with the following rituals:

- Moving to a new cowshed:

Дӧлӧвӧйӧ-двӧрӧлейо̆, батюшкаӧ-латушкаӧ, корлиличаӧ-лаленькаӧ, кудз ассььныд дитяясныдтӧ любитаныд да жалейтаныд, сідз жӧ и мисььнылм пар скӧтинанылиӧс любитӧ и жалейтӧ, пӧитӧ и кӧрлитӧ. ${ }^{37}$

Dömövöi, dvörölei, father and mother, foster mother, just as you love and pity your own children, please love and pity our cattle, give them food and drink. 
- Bringing home an animal that has just been bought or a new-born animal:

Дедушко-батюшко, дедушко-матушко! Я тебе гостинииь принёс. Мою скотину корли, пои да на мясо глади, да приголубь и шерсть очищай.

Grandfather-father, grandfather-mother! I have brought you some gifts. Give my cow food and drink, caress it and clean its fur. ${ }^{38}$

It should be pointed out here that sorcery addressing the domovoi was recorded in the Komi Priluzsky and Udorsky traditions, which are marked by close contacts with the Russian population of Kirov Oblast and Arkhangelsk Oblast.

The texts of sorcery are distinguished from ordinary speech and speech acts in terms of the ritual character of situations and the existence of rhyme, rhythm, and repetitions (Славнӧй Ёгорей, благӧславнӧй Ёгорей, сохранибережи 'great George, blessed George, save and protect us'), enumerations (любитӧ и жалейтӧ, пӧитӧ и кӧрлитӧ 'love and pity, give food and drink'), diminutive forms (дедушко-батюшко, корлиличаӧ-маленькаӧ 'grandfatherfather, foster mother'), and metaphors in texts.

\section{Incantations}

Incantations have a complex structure and composition and consist of several statements that are said in the course of a specific ritual situation. The semantics of the majority of incantations can be determined as rehabilitating, since they are aimed at improving and restoring the normal condition of domestic animals and are said in order to 'cure a sick animal', 'to bring back home a cow that spends a night in an unfamiliar place', etc.

The texts of incantations were recorded in contact areas that are representative of both the Priluzsky and Udorsky traditions, and in their linguistics and imagery they are close to the northern Russian tradition. Mainly these texts can be found in handwritten notebooks of informants alongside couplets, songs, and canonical prayers, which on the whole allows these notes to be designated as reminders in order to remember something. Some informants pointed out that they were repeating texts from the words of their mother or another woman who had good knowledge 'about cattle'. Besides, in their recorded form, the texts could also be passed over by the carriers of that knowledge. Whenever appropriate, incantatory texts were re-read, reconstructed from memory, or learned by heart. Let us have a closer look at several examples. 
Мӧс локтӧльссь.

Во иля отиа - 3 раза

На правой руке каленнӧй стена

На левой руке железного стьна на переде высокӧй гӧра

раба божия Серук мӧс

моз верль мунны

чужӧй пӧскӧтинаӧ.

чужӧй картаё. ${ }^{39}$

чужсой кӧзяйкалӧн. ${ }^{40}$

Старӧй кӧзяйкалӧн сёян-юанысс твёрдӧй калень да льс.

Выль кӧзяйкалӧн сёян-юаныс свежӧй трава да мягкӧй хлеб.
For (literally 'from') bringing back the cow.

In the name of the Father - [repeated] 3 times

A stone wall on the right hand, An iron fence on the left hand, A high mountain ahead.

The Lord's servant cow Syeruk, Let it not go far away, To somebody else's pasture, To somebody else's yard.

To another master.

The old master has food and drink, A hard stone and pine needles. The new master has food and drink, Fresh grass and soft bread.

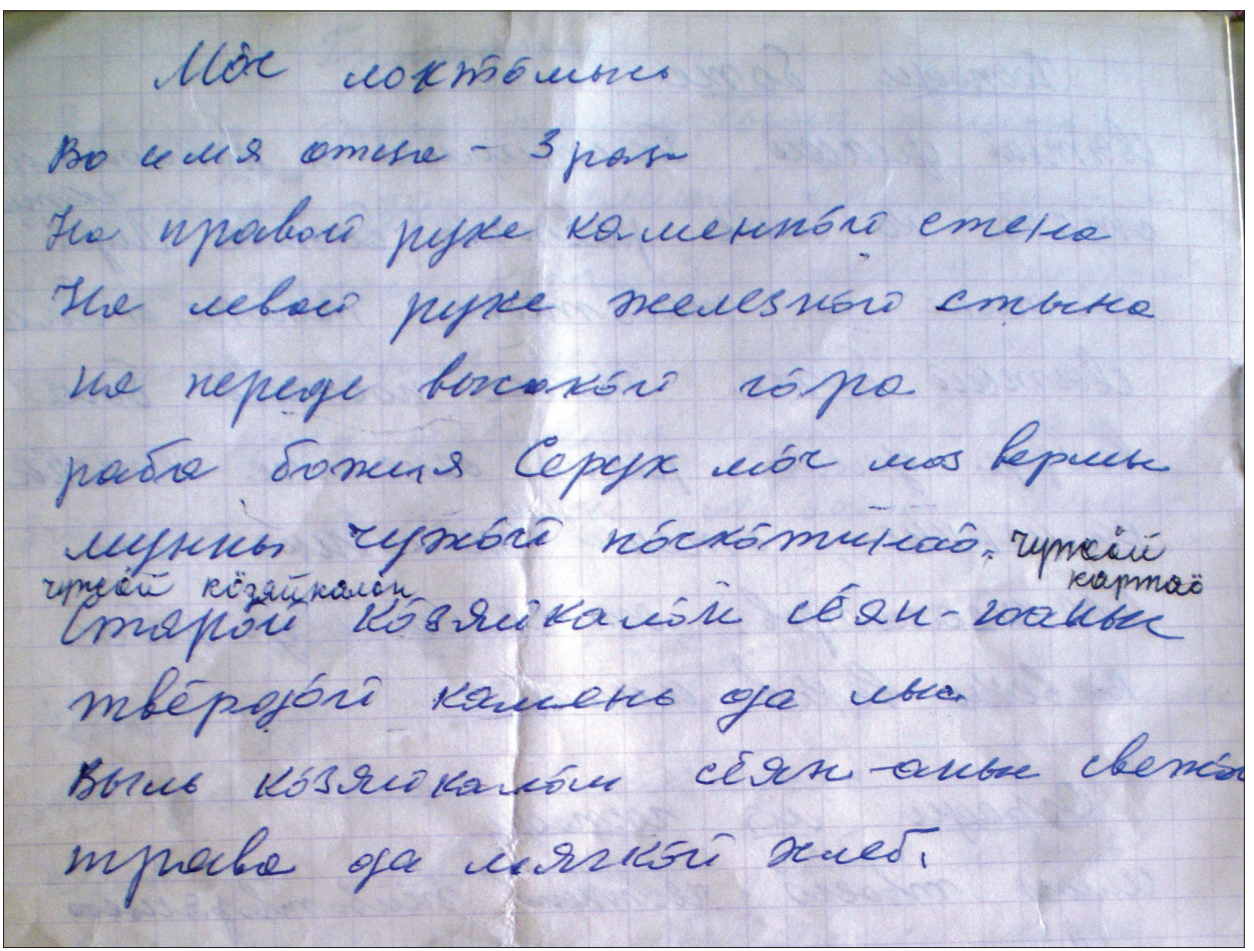

Figure 5. An incantatory text in the handwritten notebook of Nina Matveeva, born in 1931 (FFA: 28_06_78-79). Village of Yortom, Udorsky District. Photograph by Liudmila Lobanova 2011. 
The following structural parts can be distinguished in the text:

- Exposition, which was not recorded in full but can be reconstructed as in the name of the Father and the Son and the Holy Spirit', is repeated three times;

- Narrative part: “На правой руке каменнӧй стена / на левой руке железного стьна / на переде высокӧй гӧра."

- Incantatory part: "Раба божия Серук мӧс / моз верль мунны / чужӧй пӧскӧтинаӧ / чужӧй картаӧ. / Чужӧй кӧзяйкалӧн / Старӧй кӧзяйкалӧн сёян-юаныс / твёрдӧй калень да льс / Выль кӧзяйкалӧн сёян-юаныс / свежӧй трава да мягкӧй хлеб.”

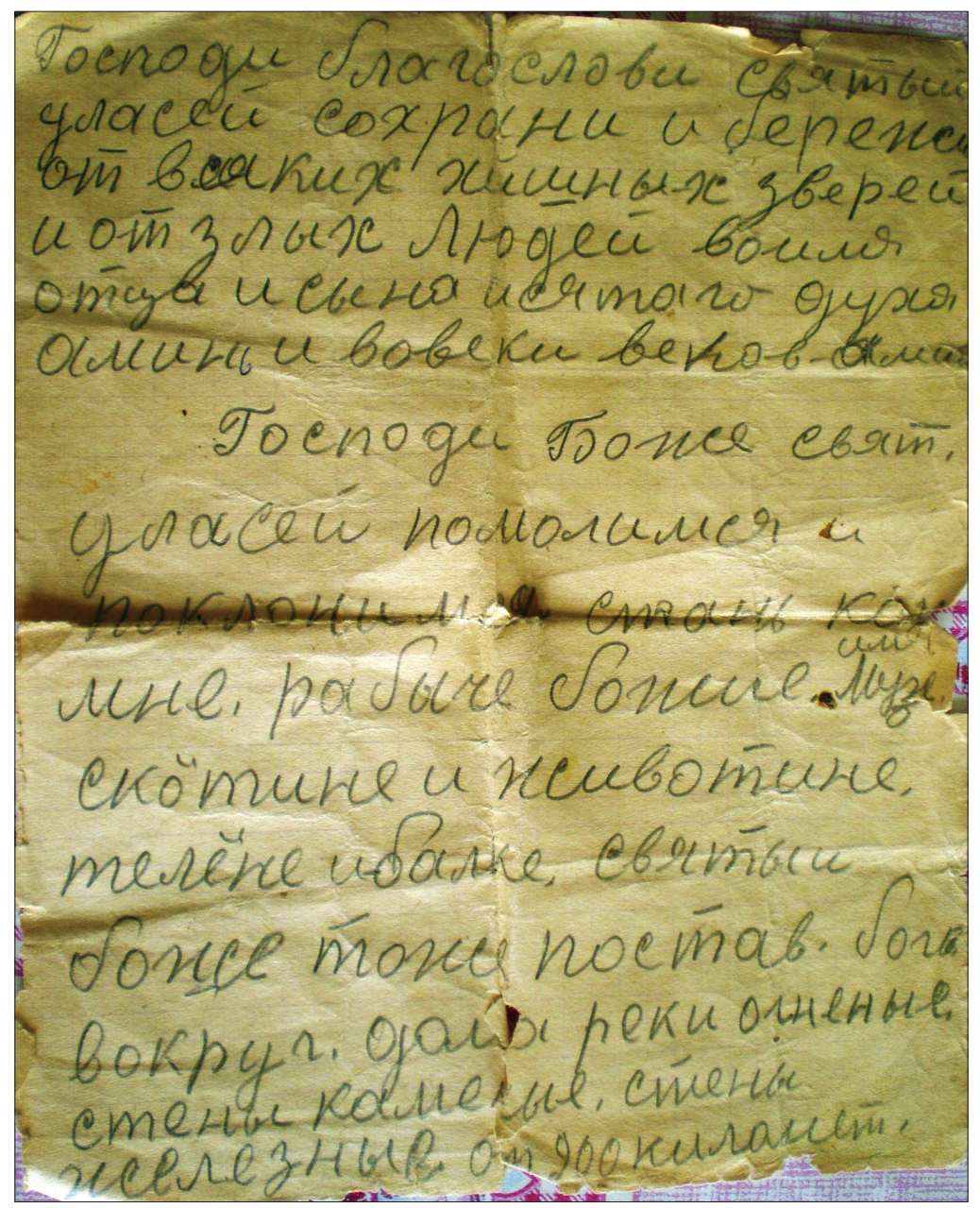

Figure 6. An incantatory text in the handwritten notebook of Nina Matveeva, born in 1931 (FFA: 28_06-142). Village of Yortom, Udorsky District. Photograph by Liudmila Lobanova 2011. 
According to the writings made between the lines and the comments of the informant provided by her during the interview, this incantation was used both when buying a cow and when letting it to the pasture.

The next text in the notes of the same informant (Fig. 6) refers to the cases when incantations are recorded in order to pass them on to someone else. It should be pointed out that, unlike other notes in the notebook of the informant, the text was written in different handwriting and on a separate piece of faded paper. While commenting on the notes, the informant mentioned that this incantation would be said whenever something happened to the cattle, ${ }^{41}$ and the text was recorded and passed on to her by an old woman from the village of Krestovo ${ }^{42}$ :

Господи Боже свят Уласей, пололился и поклонился! И стань ко мне, рабыче божие (иля) Музе скӧтине и животине, телёне и балке. Святы и боже тоже постав бога вокруг дола реки огненые, стены каленье, стень железные от 200 киланет. От зелли и до небес, вовеки веков. Алин.

My God My God Saint Ulasey, we pray and bow! Stand near me, the servant of God (name) the Muze, cattle and animals, calves and sheep. My Saint God, also do put the fiery river around the house, stone walls, iron walls from 200 kilometres (?). From the earth and to heaven, for ever and ever. Amen.

\section{Ritual dialogue}

The verbal level in certain rituals is represented by a dialogue between the two participants of the ritual, and it consists of two or three components. Ritual dialogues in the Slavic tradition have been studied by Nikita Tolstoi (1984, 1993). They have been classified and distributed into eleven topic groups. One of the groups combines ritual dialogues with the magical function of 'keeping fowl and cattle at home'. The main purpose of the rituals within this group is domesticating fowl and cattle before the start of the pasture period. In the majority of the Slavic traditions, such rituals were timed with Christmas rites, and in the northern Slavic tradition they coincided with Holy Thursday or were performed occasionally (Tolstoi 1984: 26-30; 1993: 85-87).

Such rituals were recorded in the southern districts of the Komi Republic. They were held on the morning of Holy Thursday ${ }^{43}$ with the purpose of domesticating the cattle. One of the participants went out into the yard or the hayloft and took a cow around the house (Konakov 1993: 56), and another one stayed 
at home, and they were talking with each other: Are the cows at home? - They are! They are! - Have the sheep come back? - They have! (Komi Calendar 2002: 67) It was believed that after that, the cows would always come back home from the pasture. Similar rituals were held in cowsheds at state-owned farms. On the morning of Holy Thursday, after coming to the cattle yard, milkmaids were talking with each other: Мӧсъяс ставыс абу? - Cтавыс-ставысc ${ }^{44}$ 'Have all of the cows come back? - Yes, all of them!', to make sure cows come back from the pasture and do not get lost.

Other recorded ritual dialogues are aimed at the treatment of diseases among people and cattle. Tolstoi, while studying this group, points out the 'incantatory' nature and distribution of these rituals among the Russians as well as the diversity of the means of exterminating illnesses, which are fumigated, burned, chopped, evaporated, etc. (Tolstoi 1984: 45-50; 1993: 92-98). Ritual dialogues said while fumigating a cow were recorded in the Komi tradition. In some cases, the ritual was held on the third day of the calving. "The mistress took a bowl, put a juniper spur into it, a couple of single hairs from her head, moss from three corners of the house, a chip from the threshold of the house, some hay from her shoes, and a piece of frankincense. Then she burned all of those components in the cowshed, and gave a whiff of the smoke to the cow and the calf, and then she walked around them three times. While she was doing that, she was talking to an imaginary interlocutor:

- Мыцй тшынан,

Мыци тшыннан?

- Волидзкыв тиынна.

Тьфбу волидз курваэс

Ёна колэ тшьнны.

(Vetoshkina 1982: 89-90)
- What are you purifying,

What are you purifying?

- I'm purifying the incantation.

Pooh-pooh, the incantation,

You should purify it more'.

The researcher determined the purpose of performing the ritual as 'protecting a domestic animal from blight with the help of the smoke' (ibid.).

In other adaptations, the smoke purification ritual was held with the purpose of throwing off an illness that had developed as a result of someone putting a curse on the animal. The range of objects used for purifying the animal included juniper collected on Holy Thursday and kept in the cowshed as a protective charm; pike teeth; chips from the threshold of the cowshed; cobwebs collected in the corners of the cowshed; the wool of the animal that was being purified or that was sheared from the tail base, forehead, or tail; and hay. The set of objects was set on fire, and one of the participants in the ritual asked 
questions, while the other one, who was walking around the cow against the sun, answered them:

- Кодэс тшынан?

- Кекуре ки волидзес, урекиволидзес. Кьтыссь волін, бӧр сэтче мун, пиняд бӧжтэ курччи да тодьєн лойси. ${ }^{45}$
- Who are you purifying?

- I'm purifying against the evil eye. Go back from where you arrived, bite your tail with your teeth and wallow in the bog.

The last two ritual dialogues have closing sentences, i.e. 'fasteners'. In the first case, the 'fastener' reinforces the action, while in the second case, it finishes the treatment ritual by sending the illness away.

\section{Lamentation}

In spite of the fact that I only have two examples of such texts at my disposal, ${ }^{46}$ I can have a look at their characteristics. The Komi lamentation tradition is regarded as being quite well-developed. There are local lamentation traditions and genre variations. For instance, in the Izhemsky Komi tradition, there are not only funeral and wedding lamentations, but also lullabies and calendar and labour lamentations (Filippova 2002).

\section{(Мӧсльь бӧрдэл)}

Тайтӧ, матиӧ, тайтӧ, Сюрка, Тайтӧ, тайтӧ, шӧӧ мада

Пукси шӧо̆, шооо

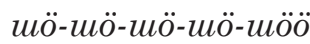

Гортӧ мидаэ, гортӧ,

Гортӧ, гортӧ, матиӧ

Гортӧ, гортӧ, чӧскьљ йӧлаэ

Гортэ, гортэ, лидаэ.

Гортэ локтэ, баксэ, тӧдэ кӧзяйка, и локтэ шылас мӧскьс. Мадаэ бара шыıас воис и бакестас, $и$ кукйыс поллась.
(Lamentation for a cow)

Come, mother, come, Syurka (literally 'Horned'), Come, come, shöö darling, Puksi shöö, shöö, shö-shö-shö-shö-shöö, Come home, darling, home, Home, home, mother, Home, home, with delicious milk, Home, home, darling,

She's coming home, mooing, she knows her lady and knows her voice. She will come by her lady's voice and moo, and her calf will moo back. 
Мӧс дзоньтэл:

Тайтэ, мадаэ,

Тайтэ, Сюрка

тайтэ, мадаэ,

Тайтэ, тайтээ,

Сӧӧ, миадаэ,

Cö-cö-cö-cö

Чӧскыд йӧлале сӧ.

Гортэ мадаэ,

Гортэ, гортэ $!^{47}$
Caressing the cow:

Come, cow, come, darling,

Come, cow, Syurka,

Come, cow, come, darling,

Come, cow, come.

Söö, darling

Sö-sö-sö-sö

With delicious milk sö,

Home, darling,

Home, home!

The recorded lamentations are proximal to lullabies. It is interesting to point out that in the first case, the text is called лӧсль боррдэл 'lamentation for a cow', while in the second case it is referred to as мӧс дзоньтэл, using a verbal noun derived from the verb дзоньтьньь 'to fix, make it whole again', which also means 'to caress' in the Izhemsky dialect of the Komi language. The function of the text can be regarded as caressing the animal to keep it healthy.

\section{CONCLUSION}

On the basis of the material collected about the Komi cattle-breeding tradition, represented mainly in the form of modern notes, different forms of incantatory texts can be distinguished. Proceeding from their formal characteristics, I have divided them into five categories. But we should not forget that these texts represent the verbal level of a ritual, and in order to carry out a thorough analysis, the semantics and structure of the ritual itself should also be studied, and the interrelations between the actional and object-specific codes of rituals must be identified. In addition to that, the comments of informants, the socalled 'speech context', and the poetics of the texts, which should be analysed in order to study the verbal level of cattle-breeding rituals, were left without consideration.

\section{ABBREVIATIONS}

AAC - Author's audio collection

FA of SSU - Folklore Archive of Syktyvkar State University

FF of ILLH - Folklore Archive of the Institute of Language, Literature, and History 
NMKR - National Museum of the Komi Republic

AHC - Author's handwritten collection

SA Komi SC - Scientific Archive of the Komi Scientific Centre of the Ural Branch of the Russian Academy of Sciences

\section{NOTES}

1 Protective house spirit.

2 It is comparable with the notion of ас гӧгӧр тӧднь 'knowledge about (literally 'around') yourself', челядь гӧгӧр тӧдньь 'knowledge about (literally 'around') children', and it means the preservation of integrity and health on the whole, and is based on the preventive aspect of the incantatory Komi tradition (Panyukov 2009: 166-204).

3 Recorded by L. Lobanova in the village of Anyb, Ust-Kulomsky District, in 1994, from Valentina Lobanova, born in 1953 (AAC).

4 Нимкьљв means an incantation, an incantatory act (Ulyashev 1999; Panyukov 2009: 166-204).

5 Recorded by L. Lobanova in the village of Cheksha, Noshulsky village soviet, Priluzsky District, on 23 June 2006, from Aleksandr Vakhnin, born in 1928 (AAC).

6 See Neklyudov 2011 about the differences of ritual practice and information about it.

7 Material collected by Pavel Savvaitov, dating back to the middle of the nineteenth century, is archived in the Manuscript Department of the Russian National Library (St. Petersburg); material collected by Vasily P. Nalimov at the beginning of the twentieth century is preserved in the Archive of the Finno-Ugric Society (SuomalaisUgrilaisen Seuran Arkisto); the folkloric-ethnographic material collected by the students of the Pedagogical College in the 1930s is preserved at the National Museum of the Komi Republic; the material of folkloric-ethnographic and linguistic fieldwork collected by the staff of the Komi Scientific Centre in the 1960-1980s.

8 Recorded by G. Savelyeva \& A. Panyukov in the village of Puchkoma, Udorsky District, in 1999, from Maria Matveeva, born in 1946 (FF of ILLH: A0525-13).

9 Recorded by L. Lobanova in the village of Gar, Spasporubsky village soviet, Priluzsky District, on 20 June 2005, from Klavdia Fomina, born in the village of Kuliga in 1937 (FF of ILLH: A 1564).

${ }^{10}$ Recorded by L. Lobanova in the village of Yortom, Udorsky District, on 23 June 2001, from Galina Matveeva, born in 1961 (AAC).

${ }^{11}$ Recorded by G. Savelyeva \& A. Panyukov in the village of Nivshera, Kortkerossky District, in 2000, from Anna Slyuser, born in 1906 (FF of ILLH: B1114-73).

${ }^{12}$ Recorded by T. Kaneva in the village of Ozyag, Kuzhbinsky village soviet, UstKulomsky District, in 1999, from A. Yeseva, born in 1927 (FF of ILLH: B1206). 
${ }^{13}$ Recorded by G. Savelyeva \& A. Panyukov in the village of Puchkoma, Udorsky District, in 1999, from Maria Matveeva, born in 1946 (FF of ILLH: B0510-69).

${ }^{14}$ Recorded by L. Lobanova on 23 in the village of Yortom, Udorsky District, on 23 June 2011, from Nina Matveeva, born in 1931 (AAC).

15 They mean the prayer 'Let God rise'.

${ }^{16}$ Recorded by G. Savelyeva \& A. Panyukov in the village of Nivshera, Kortkerossky District, in 2000, from Aleksandra Zhizheva, born in 1928 (FF of ILLH: B1113-44).

17 The specified meaning of the particle maŭ, which occurs in the Izhemsky dialect, is specified in the work of Galina Fedyuniova with the indication of the possible etymology of this particle (Fedyuniova 2009: 72).

${ }^{18}$ Recorded by E. Vetoshkina in the village of Lyaty, Kozhmudorsky village council, Ust-Vymsky District, in 1978, from Olga Kozlova, born in 1918 (SA Komi SC: F.5. Op. 2. L.226-v. L.48).

19 The definitions of closed structure and open structure were formulated by V. Kharitonova (1992).

${ }^{20}$ In the Komi language there is one word for wool and down feather.

${ }^{21}$ Recorded by G. Savelyeva \& A. Panyukov in the village of Puchkoma, Udorsky District, in 1999, from Maria Matveeva, born in 1946 (FF of ILLH: A0525-14).

${ }^{22}$ Recorded by L. Lobanova in the village of Yortom, Udorsky District, on 23 June 2001, from Galina Matveeva, born in 1961 (AAC).

${ }^{23}$ Recorded by L. Lobanova in the village of Yortom, Udorsky District, on 23 June 2011, from Nina Matveeva, born in 1931 (AAC).

${ }^{24}$ Recorded by G. Savelyeva \& A. Panyukov in the village of Nivshera, Kortkerossky District, in 2000, from Aleksandra Zhizheva, born in 1928 (FF of ILLH: B1113-46).

${ }^{25}$ Recorded by G. Savelyeva \& A. Panyukov in the village of Nivshera, Kortkerossky District, in 2000, from Aleksandra Zhizheva, born in 1928 (FF of ILLH: B1113-47).

${ }^{26}$ Recorded by L. Kondratyeva in the village of Uzhga, Koygorodsky District, in 1935, (NMKR: KP-12485. L. 514).

${ }^{27}$ Recorded by Tarakanova in the village of Pazhga, Syktyvdinsky District, in 1935 (NMKR: KP-12485. L. 497).

${ }^{28}$ Recorded by K. Rédei at the Upper Vychegda in 1964 (Rédei 1978: 234).

${ }^{29}$ Recorded by G. Savelyeva \& A. Panyukov in the village of Nivshera, Kortkerossky District, in 1996, from Maria Mikhailova, born in 1922; and from Agnia Zhizheva, born in 1937 (FF of ILLH: B1102-41).

${ }^{30}$ Recorded by G. Savelyeva \& A. Panyukov in the village of Nivshera, Kortkerossky District, in 1996, from Nina Mikhailova, born in 1923 (FF of ILLH: B1102-19). 
${ }^{31}$ Yoma is a Komi folkloric and mythological character. In this case Yoma acts as a marker of a foreign space as opposed to the sheep's own household.

${ }^{32}$ Recorded by L. Lobanova in the village of Kuliga, Spasporubsky village soviet, Priluzsky District, on 22 June 2005, from Maria Fomina, born in the village of Shpal in 1928 (AAC).

${ }^{33}$ Recorded by L. Lobanova in the village of Gar, Spasporubsky village soviet, Priluzsky District, on 20 June 2005, from Klavdia Fomina, born in the village of Kuliga in 1937 (FF of ILLH: A1564).

${ }^{34}$ Recorded by L. Lobanova in the village of Anyb, Ust-Kulomsky District, in 1994, from Valentina Lobanova, born in 1953 (AAC).

${ }^{35}$ Recorded by L. Lobanova in the village of Yortom, Udorsky District, on 28 June 2011, from Nina Matveeva, born in 1931 (AAC).

${ }^{36}$ Recorded by L. Lobanova in the village of Anyb, Ust-Kulomsky District, in 1994, from Anna Pimenova, born in 1914 (AAC).

${ }^{37}$ Recorded by V. Arefyeva in the village of Chuprovo, Udorsky District, in 2011, from N. M. Shlopova, born in 1946 (AHC).

${ }^{38}$ Recorded by V. Arefyeva in the village of Muftyuga, Chuprovsky village council, Udorsky District, in 2011, from Nina Fedorova, born in 1955 (AHC).

${ }^{39}$ Added in different handwriting in black ink.

${ }^{40}$ Added above the next line in different handwriting in blue ink.

${ }^{41}$ Recorded by L. Lobanova in the village of Yortom, Udorsky District, on 28 June 2011, from Nina Matveeva, born in 1931 (AAC).

42 The village of Krestovo was a part of the Yortomsky village soviet. This place is remarkable in that it held the status of a religious centre. A monastery stood here once, on the territory of which the first church in Yortom village was founded.

${ }^{43}$ The rituals that were held on Holy Thursday are described in detail in Lobanova 2012.

${ }^{44}$ Recorded by A. Rassykhaev and L. Sazhina in the village of Karvudzhem, Grivensky village soviet, Koygorodsky District, in 2002, from E. M. Ushakova, born in 1918 (FF of ILLH: A1604).

${ }^{45}$ Recorded by L. Lobanova in the village of Anyb, Ust-Kulomsky District, in 1994, from Anna Pimenova, born in 1914 (AAC).

${ }^{46}$ I am grateful to the staff of the Folklore Archive of the Institute of Language, Literature and History, Galina Savelyeva and Anatoly Panyukov, for providing me with these texts and for the opportunity to study them.

${ }^{47}$ Recorded by A. Mikushev and P. Chistalyov in the village of Brykalansk (Kotlas), Izhemsky District, in 1960, from Ulyana Smetanina, 65 years old, and from Anna Smetanina (FF of ILLH: K-45: 12). 


\section{REFERENCES}

Fedosova, Kseniia 2007. Zagovory v obriade pervogo vygona skota: printsipy var'irovaniia $i$ strategii tekstoporozhdeniia v ustnoi i pis'mennoi traditsii. [Incantations in the Ceremony of the First Grazing of the Cattle: The Principles of Variation and Strategy of Text Creating in Oral and Written Tradition.] Avtoreferat dissertatsii na soiskanie uchenoi stepeni kandidata filologicheskikh nauk. Moscow University. Available at http://www.dslib.net/folklor/zagovory-v-obrjade-pervogo-vygonaskota-principy-varirovanija-i-strategii.html, last accessed on 15 May 2019.

Fedyuniova 2009 = Fediuneva, Galina. K etimologii chastitsy tai 'ved', zhe' v komi i mansiiskom iazykakh. [To the Etymology of the Particle tai 'After All' in the Komi and Mansi Languages.] Gumanitarnye nauki v Sibiri, No. 4, pp. 70-72.

Filippova, Valentina 2002. Prichitanie v kontekste obriadovoi poezii. [Lamentation in the Context of Ceremonial Poetry.] In: P. Limerov (ed.) Fol'kloristika Komi. Syktyvkar: Izdatel'stvo Komi NTs UrO RAN, pp. 61-72.

Kharitonova, Valentina 1992. Zagovorno-zaklinatel'naia poeziia vostochnykh slavian: Konspekty lektsii. [Incantatory Poetry of the East Slavs: Synopses of Lectures.] Lviv: LGU.

Komi Calendar 2002 = Filippova, Valentina \& Kaneva, Tat'iana (comps.), Vlasov, Andrei (ed.) Traditsionnyi narodnyi kalendar' komi: Materialy. [Komi Traditional Folk Calendar: Materials.] Syktyvkar: SGU.

Konakov, Nikolai 1993. Ot Sviatok do Sochel'nika: Komi traditsionnye kalendarnye obriady. [From Christmastide to Christmas Eve: Komi Traditional Calendar Rituals.] Syktyvkar: Komi knizhnoe izdatel'stvo.

Kudryashova 1991 = Kudriashova, Vera. Zagovory naroda komi. [Incantations of the Komi People.] In: Iurii Rochev (ed.) Obshchee i osobennoe v zhanrakh komi fol'klora i literatury. Trudy Instituta iazyka, literatury i istorii, Vyp. 48. Syktyvkar: Komi nauchnyi tsentr UrO AN SSSR, pp. 34-45. Available at https://www.booksite.ru/ fulltext/komifolk/text.pdf, last accessed on 15 May 2019.

Lobanova, Liudmila 2012. Skotovodcheskie ritualy Velikogo chetverga. [Cattle Breeding Rituals on Maundy Thursday.] Fol'kloristika komi. Trudy instituta iazyka, literatury i istorii, Vyp. 70. Syktyvkar: Komi NTs UrO RAN, pp. 101-121.

Lytkin \& Gulyaev 1999 [1970] = Lytkin, Vasilii \& Guliaev, Evgenii. Kratkii etimologicheskii slovar' komi iazyka. [Concise Etymological Dictionary of the Komi Language.] Syktyvkar: Komi knizhnoe izdatel'stvo.

Neklyudov 2011 = Nekliudov, Sergei. "Etnograficheskii fakt" i ego fol'klornye eksplikatsii. ["The Ethnographic Fact" and Its Folkloric Explications.] In: A. Baiburin \& T. Shchepanskaia (eds.) Fol'klor $i$ etnografiia. $K$ devianostoletiiu so dnia rozhdeniia K. V. Chistova. St. Petersburg: MAE RAN, pp. 40-47. Available at http://www.kunstkamera.ru/files/lib/978-5-88431-209-8/978-5-88431-209-8.pdf, last accessed on 15 May 2019.

Panyukov 2009 = Paniukov, Anatolii. Dinamika razvitiia komi fol'klornykh traditsii $v$ kontekste teorii samoorganizatsii. [Development Dynamics of Komi Folk Traditions in the Context of the Theory of Self-Organization.] Syktyvkar: Izdatel'stvo Komi NTs UrO RAN. 
Permyakov 1988 = Permiakov, Grigorii. K voprosu o strukture paremiologicheskogo fonda. [On the Question of the Structure of the Paroemic Corpus.] In: G. Permiakov. Osnovy strukturnoi paremiologii. Moscow: Nauka, pp. 80-106. Available at https://www.ruthenia.ru/folklore/permyakov1.pdf, last accessed on 15 May 2019.

Popova, Eleonora 2000. Mezhdometie. [Interjection.] In: Galina Fediuneva (ed.) Öniia komi kyv. Sovremennyi komi iazyk: Morfologiia. Syktyvkar: Komi knizhnoe izdatel'stvo.

Rédei, Károly 1978. Zyrian Folklore Texts. Budapest: Akadémiai Kiadó.

Sidorov, Aleksei 1997 [1928]. Znakharstvo, koldovstvo i porcha u naroda komi: Materialy po psikhologii koldovstva. [Folk Healing, Magic and Witchcraft among the Komi People: Materials of the Psychology of Magic.] St. Petersburg: Aleteiia. Available at https://www.booksite.ru/fulltext/sidorov/text.pdf, last accessed on 15 May 2019.

SSKZD 1961 = Zhilina, Tat'iana \& Sakharova, Marfa \& Sorvacheva, Valentina (comps.) Sravnitel'nyi slovar' komi-zyrianskikh dialektov. [Comparative Dictionary of the Komi-Zyrian Dialects.] Syktyvkar: Komi knizhnoe izdatel'stvo.

Tolstoi, Nikita 1984. Fragment slavianskogo iazychestva: arkhaicheskii ritual-dialog. [A Fragment of the Slavic Paganism: Archaic Ritual Dialogue.] In: N. Tolstoi (ed.) Slavianskii i balkanskii fol'klor: Etnogeneticheskaia obshchnost' i tipologicheskie paralleli. Moscow: Nauka, pp. 5-72. Available at https://inslav.ru/images/stories/ pdf/SBF-1984.pdf, last accessed on 15 May 2019.

Tolstoi, Nikita 1993. Eshche raz o slavianskom ritual'nom dialoge. [Once Again about the Slavic Ritual Dialogue.] In: S. Tolstaia \& T. Tsiv'ian (eds.) Slavianskoe $i$ balkanskoe iazykoznanie: Struktura malykh fol'klornykh tekstov. Moscow: Nauka, pp. 82-110. Available at https://inslav.ru/images/stories/pdf/SBJa-1993. pdf, last accessed on 15 May 2019.

Ulyashev 1999 = Uliashev, Oleg. Nimkyv. [Incantation.] In: Anna-Leena Siikala \& Vladimir Napol'skikh \& Mihaly Hoppal (eds.) Entsiklopediia ural'skikh mifologii. T. 1. Mifologiia komi. Moscow \& Syktyvkar: DIK, pp. 256-258. Available at https://www.academia.edu/8463469/, last accessed on 16 May 2019.

Uotila, Toivo 2006. Syrjänische Texte. Band V. Komi-Syrjänisch: Ober-Vyčegda-Dialekt. M. Žikins Texte. Gesammelt von T. E. Uotila, übersetzt und herausgegeben von P. Kokkonen. Helsinki: Suomalais-Ugrilaisen Seura.

Vetoshkina, Elena 1982. Proizvodstvennye i semeino-bytovye zagovory u komi. [Production and Family-Household Incantations among the Komi People.] Natsional'noe i internatsional'noe $v$ komi literature i fol'klore. Trudy Instituta iazyka, literatury i istorii, Vyp. 26. Syktyvkar: Komi NTs UrO RAN, pp. 87-97.

Zhilina, Tatiana 1975. Verkhnesysol'skii dialekt komi iazyka. [Upper-Vychegda Dialect of the Komi Language.] Moscow: Nauka. 


\title{
CALLING UPON A DOMOVOI IN THE CHILDREN'S GAME TRADITION OF THE KOMI
}

\author{
Aleksey Rassykhaev \\ Researcher \\ Department of Folklore, Institute of Language, Literature, and History \\ Komi Science Centre of the Russian Academy of Science, Russia \\ Email: rassyhaev@mail.ru
}

\begin{abstract}
This article deals with the children's game of calling upon a domovoi ${ }^{1}$, which is unique for the traditional spiritual culture of the Komi. New authentic texts as well as archival material that has never been used before is cited. Their analysis allows the area of the spread of this game to be expanded. According to the new sources, it did not only exist among the Komi living on the shores of the basin of the Vychegda River (with the tributaries of the Vishera, the Vym, and the Sysola), but also among the northern Komi-Permiaks in the traditions of Kosinsky District. The games have similar scenarios and are aimed at establishing contact with the invisible inhabitant of the house living in the cellar, and checking if it really exists. The most noticeable variation exists in the names of the demonym, poetic addresses, and characteristics. The image and terminology pertaining to the domovoi addressed in the game contain reflections of mythological concepts that are similar to 'adult folklore', but quite often the addresses to the character called upon take on the features of 'childishness', i.e., diminutive forms, reduplication, and personal names. In the context of experiencing collective fear, this game is close to the magically playful calling upon the neo-mythopoetic characters (the Queen of Spades, a Dwarf, devils, etc.), which is common among modern schoolchildren, including the Komi schoolchildren.
\end{abstract}

Keywords: children's game, domovoi, Komi folklore, Komi-Permiak folklore

\section{INTRODUCTION}

A children's game involving calling upon a domovoi from the cellar is specific to the Komi folk culture. In scientific literature, it has two names: Yuri Rochev figuratively calls this game гӧбӧч айка 'the spirit of the cellar' (the researcher translates the name as the 'lord of the cellar') (Rochev 1972: 135; 1979: 219), while Dmitry Nesanelis refers to it as a гӧрд гача (literally 'wearing red trousers') (Nesanelis 1994: 95). 
This game was the subject of a separate research by Nesanelis, who considered it from the ethno-semiotic perspective in the article titled "Старинная игра детей коми 'гӧрд гача': Опыт семантического анализа” (The Ancient Game 'görd gacha' of the Komi Children: Semantic Analysis) (Nesanelis 1989). The author analyses the most notable features of this house spirit that children call upon from the cellar, such as flabbiness that can be compared with clay, the red colour of its body and clothing (trousers) that is often perceived in a negative way, and its colourfulness which, in the opinion of the researcher, make it possible to bring it nearer to the mythological 'Purusha'. During the game, children actualize their perceptions of the spatial opposition of up and down (the domovoi in the cellar), the opposition of the things that are your own and someone else's (friend/foe), the ancestors' world and the world of the living, chaos and space. While accepting a number of standpoints expressed in the research, I will pay special attention to the facts that have been unaddressed so far. Mainly I will be citing authentic texts recorded in recent decades, and expanding the geography of the distribution of this game.

\section{DESCRIPTION OF THE GAME}

From the perspective of typology, this game can be called funny, a kind of an impromptu game, since it does not follow any specific rules that exist in the majority of other games, such as the game leader, punishing a player that has lost, etc.

The first description of this game that we know about was given at the end of the nineteenth century by Leonid Kaplin, a student of Vologda Theological Seminary, who recorded the existence of this game in Derevyansk village in the area of the Vychegda River:

Several young men gather together in a house, and they close the windows so that it will go dark. They sit on benches with their legs raised so that the domovoi does not cut them with a scythe or a sickle. They push the doors of the cellar wide open. One young man is standing on a chair near the entrance, with a stick in his hand, striking it against a chair, saying: "Our neighbour and brother, come out, come out, and taste our water, bread, and salt". After he has said that, the domovoi rolls out of the cellar on rugs in the shape of an egg. After waiting a little, the players rush to open the windows to see whether it was a domovoi or not. If you throw a log into that egg (the domovoi), it will pour out gold and silver. ${ }^{2}$ (Nesanelis 1999) 
In his work, Kaplin mentions other names of the domovoi as well, for example, виж кок 'the yellow foot', recorded in the village of Veslyana, which stands on the Vym River (the current Knyazhpogostsky District). At the beginning of the game, children would close the windows and stick a knife into the floor in front of the entrance to the cellar (Nesanelis 1999).

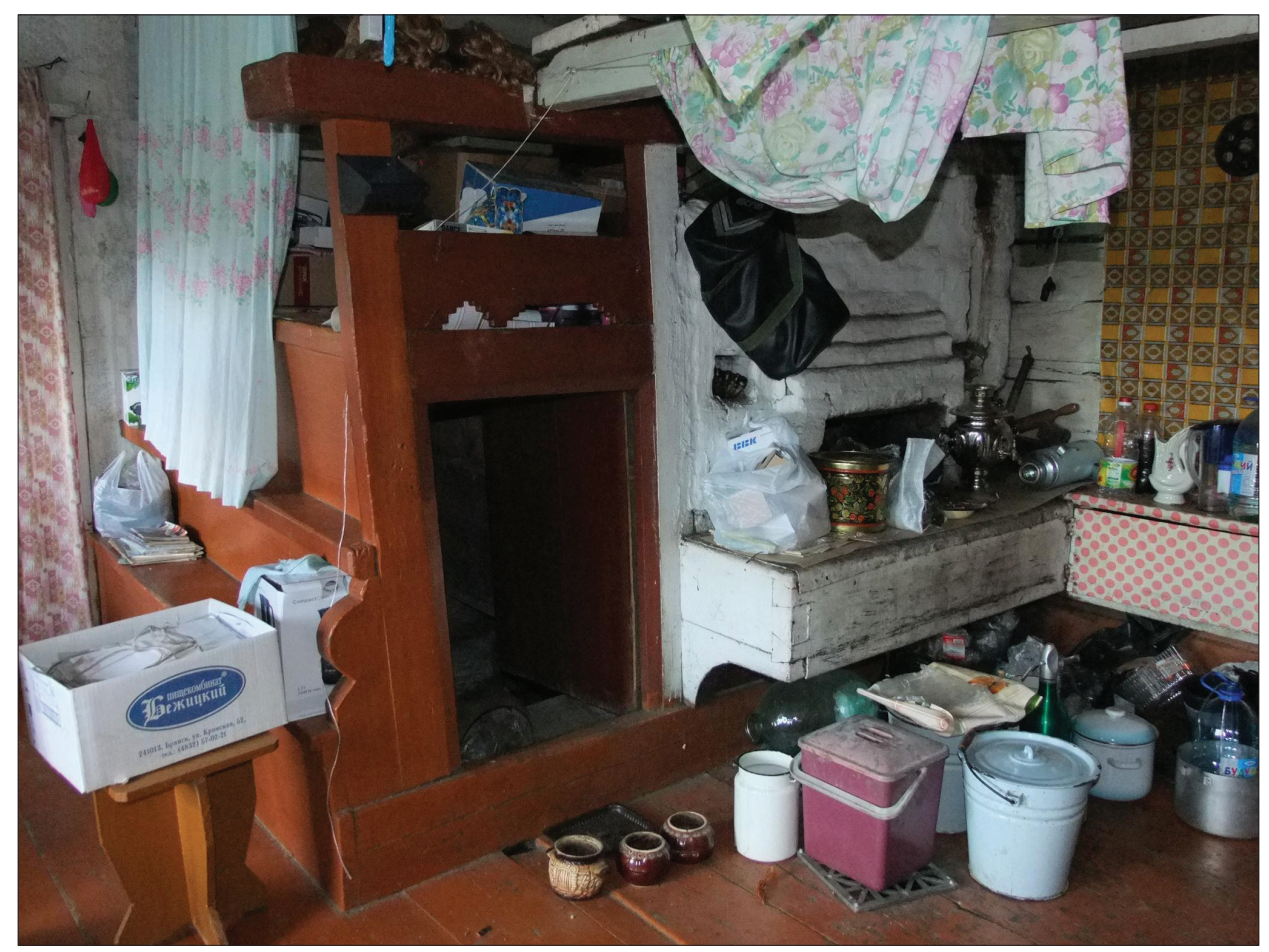

Figure 1. Entrance to the cellar, in front of which the game is usually played. Village of Bolshelug, Kortkerossky District. Photograph by Aleksey Rassykhaev 2015.

The second description of the game from top down was made by A. E. Agafonova, a student of the Komi Teachers' Training College, who recorded a game named орт петкӧдӧм 'taking out the soul-ort's, in Syktyvkar in 1935. Children would curtain the windows, put water and bread next to the cellar doors and address the domovoi together: 


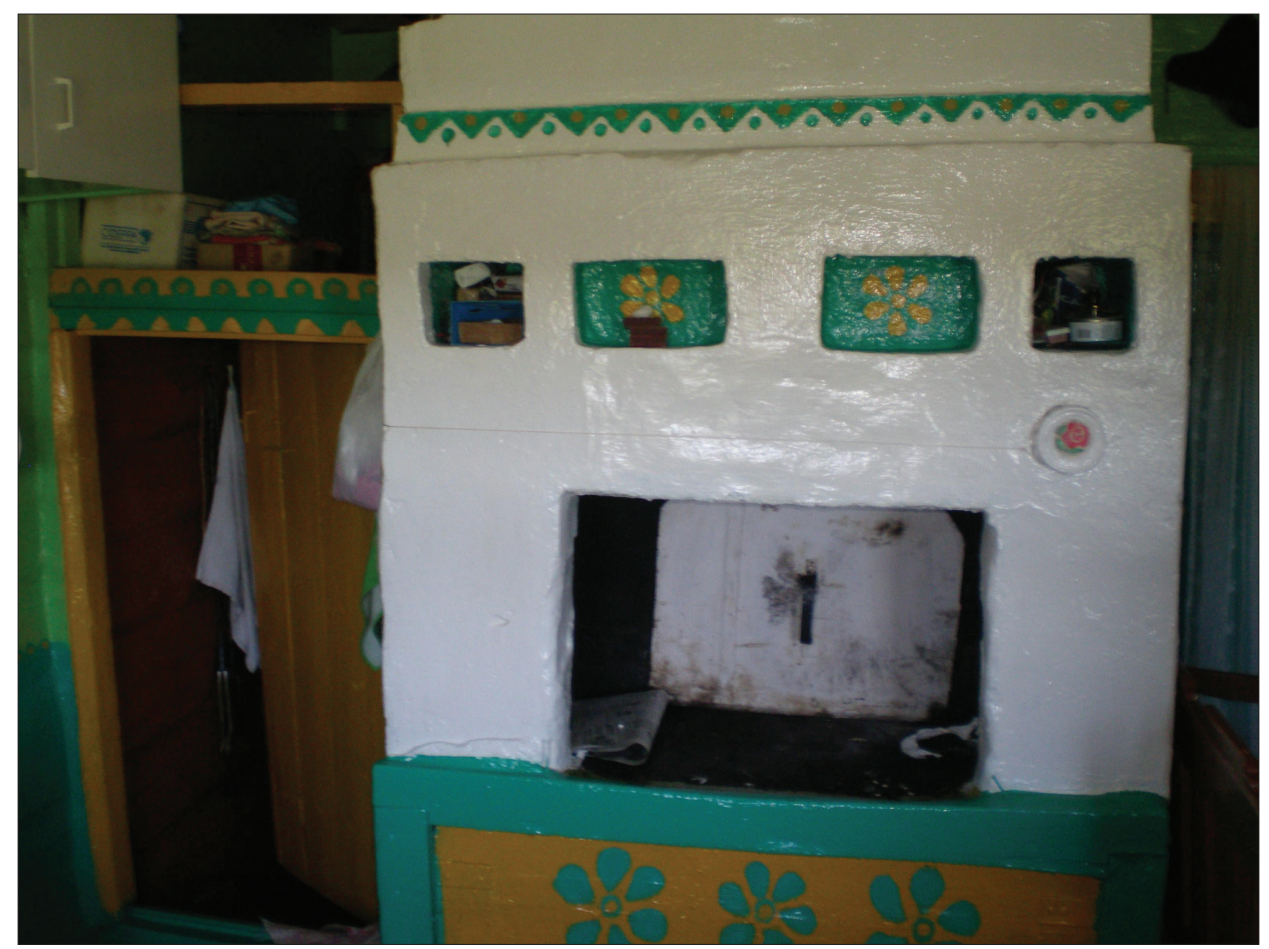

Figure 2. Entrance to the cellar, in front of which the game is usually played. Painting on the stove is an example of the modern naive art. Village of Veslyana, Knyazhpogostsky District. Photograph by Liudmila Lobanova 2016.

Гӧбӧч улысь пачсай айка, Петав жӧ, петав, Вым няньӧн вердал, Пань тыр ваӧн юкталал! ${ }^{4}$
The spirit who lives behind the stove, come out of the cellar, we will give you bread and butter to eat and give you water to drink!

In the comments made about the game it was pointed out that, while calling upon the domovoi, players would sometimes collapse because of fear.

From other descriptions we learn that the game was most often played in summer (during the haymaking period) when adults were out in the field. After closing windows in the house and putting bread and salt right next to the entrance to the cellar, children would take a fire iron and climb on the stove, from which they called upon 'the neighbour and brother'5 (Sorvacheva \& Zhilina 1971: 72-73). In other versions of the game children climbed on the sleeping 
bench, trunks, and benches, and would take scissors, knives, sticks, pounders, or oven forks in their hands:

Тупкалал ӧшиньяс, укват босьтали, да уквата мортіс каяс лабиче, а мукедіс ворсэні джоджин. Ставніс шувалэні: Пи-пи тойин, петаллі, Ива Шорлэн нянис кылэ, Поплэн нянис сотче! Ӧшиньтэ костэдіштаснь и югидіс югдэдас, сэк горедал: "Пипи тойин петэ!" Эсся ставен пьциялм, полал да. ${ }^{6}$
Let us close the windows, take an oven fork, and the person with the oven fork should stand on the bench. Others are playing on the floor. Everyone says: $\mathrm{Pi}-\mathrm{pi}^{7}$ the pounder, come out, There is a smell of bread at Iva Shor's ${ }^{8}$, Bread is burning at the priest's house! We would open [a curtain], and a ray of light would come in, and then we would shout: 'Pi-pi the pounder is coming out!' And then we would all run away, because we were scared.

In some versions of the game, one of the players (the oldest and the most experienced) enters the cellar before the game starts and then walks out of it after saying specific words. There are over twenty descriptions of this game at our disposal, the scenarios of which virtually do not differ from the ones listed above.

\section{THE DISTRIBUTION OF THE GAME}

According to the publications of Rochev and Nesanelis, the geography of the game of calling upon the domovoi from the cellar is limited to three districts of the Komi Republic: Ust-Vymsky, Ust-Kulomsky, and Syktyvdinsky districts. The analysis of archival sources and expeditions has allowed the area of the distribution of the game to be expanded along the shores of the Vychegda River (with the tributaries of the Vishera, the Vym, and the Sysola), where it was recorded in the following inhabited localities: Veslyana village in Knyazhpogostsky District; Ust-Vym village in Ust-Vymsky District; the villages of Ozel and Pazhga in Syktyvdinsky District; the city of Syktyvkar; the villages of Kuratovo and Mezhador in Sysolsky District; the villages of Bolshelug, Vazhkurya, and Nivshera in Kortkerossky District; and the villages of Anyb, Derevyansk, Don, Kerchomya, Nizhny Voch, Pozheg, Pomozdino, and Ust-Kulom in UstKulomsky District. 
Additionally, while conducting field research among the Komi-Permiaks who lived in the Komi-Permiak Okrug in Perm Krai in 2011, the author of this work recorded a similar game in the villages of Churaki and Puksib in Kosinsky District. ${ }^{9}$ What follows is a description of the 'Susedushko' ('Neighbour') game (суседушкоьсь орсльллілӧ) recorded in the village of Churaki:

Няньис эл дак, картокаторрез да If there is bread in the house, you няньторрез пуктан, крӧшитан take potatoes and bread, crumble бекӧрӧ да, джоджуллэз вӧллісӧ, them onto a plate. There used to осьтан да, сія джоджулсӧ осьтан, сэтчин льиикӧ вылас, пуктан лабич вылас, и босьтан укват ли заступ ли и сійӧн керку гӧгӧрат [нрзб]:

Суседушко-вартанушко!

Хлебушко да соль,

Ми тәд пуктіли.

Миянль бурджька кер!

Сія ешшӧ сольцтан дак. Сія кьскан - дак сэтшӧл чӧскьљы be cellars [in houses], so you would open the cellar and put a plate with bread and potatoes on the bench, then you would take an oven fork or a spade and bang with it [all around the house]:

Our neighbour, our brother!

We have brought

bread and salt to you.

Do some good for us!

Сусеткуыс сія сэтчӧ солалас сэсся. Ӧддьӧн сійӧн лььрддььıсял да сёял. [...] A кор нянььє вӧлі, сэки и орсали, кор окота сёйнь. ${ }^{10}$

And then you put salt on that

[bread]. It is so delicious when you take it out! Susetku would put some salt on it. And then we would grab it away from each other and eat it. ... We would play that game when there was bread, when we were hungry.

It was the first time when the existence of this game among the Komi-Permiaks was observed. The fact of making a recording of this game among the KomiPermiaks expands the area of distribution of this children's game of calling upon the domovoi and allows us to talk about a possible existence of the contact area somewhere on the banks of the Upper Vychegda or the Upper Kama. The northern part of Kosinsky District of Perm Krai borders on the southern inhabited localities of Ust-Kulomsky District of the Komi Republic, in which the game under consideration, according to the data collected, is mostly developed. 


\section{TERMINOLOGY}

The game under consideration has a number of different names, the most important discriminating feature of which is the name of the domovoi that is called upon. The name of this mythological character mainly appears in poetic addresses to him. In the saying within the game some of the names originate from Russian demonym words, such as $\partial e \partial$ 'old man, grandfather' and суседко 'dear neighbour', by adding diminutive forms and rhymed paired words: суседушка-братанушко 'dear neighbour-brother' (Derevyansk), соседушковоседушко 'dear neighbour' (Anyb), дедушка-бедушка 'dear grandfather' (UstKulom), дедӧ-бедӧ 'old man, grandfather', дедушко-бедушко 'dear grandfather' (Bolshelug), дедушко 'dear grandfather' (Pazhga). In the same line, we should consider the semantic doubles дедӧ-пӧльӧ (пӧльӧ 'a father's father, a grandfather') (Kuratovo and Mezhador). It is worth noting that the addresses суседушко and $\partial e \partial$ are regularly used in various sayings that are uttered in Komi rituals related to cattle raising.

In the Upper Vychegda versions, the names with the second part containing the word тоин 'pounder' have been recorded. The first part is sometimes too difficult to understand; however, it can still be etymologized with a degree of likelihood: пипу тоин 'aspen pounder' (Pozheg, Nizhny Voch, Pomozdino); nи-пи тойин (Pozheg, Vazhkurya), припетойuн (Kerchomya), npune is a desemantisation of the word nuny 'aspen'. It might be the case that aspen was used for making pounders, which translated into the name of the domovoi in the game. It is notable that, according to the information provided by one of the informants, a pounder is used as a game attribute:

Сыц гӧлбӧчтӧ йигналан вӧлі.

Сэсся занавесалан ӧшиньяснылӧс.

Сэсся челядь чукарыљ босьтан

мьıйкӧ, этія гырйын тойин

выйил, да кералан:

Припетойин, пет жӧ, пет, Сера кычи, эн жӧ пет! $!^{11}$
The cellar was locked. Then

windows were curtained. Then the children took a pounder and started banging with it:

Pripetoiin, come out, come out, Spotted puppy, don't come out!

Some of the names refer to the colour and a general description of the character called upon from the cellar: шыра-каня, матушка 'a mouse and a cat, a mother' (Don), кос петук 'a dry cockerel' (Ozel), виж кок 'a yellow foot' (Veslyana), гӧрд косаа 'with a red plait', гӧрд гача 'wearing red trousers', гӧбӧч айка 'the spirit of the cellar' (Syktyvkar). 
In some cases, the domovoi was attributed with a human name that was used for scaring naughty children: чурка Микипер 'bastard Nikephoros' (Nizhny Voch), чилля Ёгор 'Egor with a penis' (Pomozdino).

In the Komi-Permiak version of the game, the domovoi is referred to as a суседушко-вартанушко 'a neighbour' (Churaki) or сюсю-баба (Puksib). It is possible that the word вартанушко is reduplicative from the word вартан, i.e., a threshing flail; something that is used for banging around while calling upon domovoi, to make some noise; or from братанушко (compare with the demonym суседушка-братанушко recorded in Derevyansk). It can be assumed that сюсю is the reduced stem of the words суседушко or сусеткy, which are used to refer to the mythological character in the Kosinsky folklore tradition. The answer that was given by the informant to the question 'Who is Syusyubaba?' is remarkable: - 'A cусеткуыс! Cусетку сія. А мыцй нӧ, орсіканылм бара Сюсю-бабаӧн шуал' ('This is susetku. Susetku. In the game, we call him Syusyu-baba'). ${ }^{12}$

Meanwhile, in the addresses within the game no such names of the character that are widespread in folklore traditions, in which the game of calling upon the domovoi existed, can be observed: бубыля (Syktyvkar), бубиля (Dereviansk, Kerchomia) ${ }^{13}$, бубуля (Syktyvkar), бубуня (Middle Sysola), буба (Bogorodsk) (SSKZD 1961: 28); олься, оліся, ольсь 'the living thing; the inhabitant' (SSKZD 1961: 259); керка видзысь 'the guardian of the house'.

After having studied the names for the domovoi used in games, it can be assumed that a ban on directly naming this mythological character is related to reducing the children's fear of something unknown and inexplicable and creating the situation that is as favourable for contacting supernatural forces as possible.

\section{MYTHOLOGICAL MOTIFS OF THE GAME}

In the game of calling upon the domovoi there are a number of archaic perceptions, which has already been mentioned before (see Nesanelis 1989). However, within the framework of this paper, I will point out some other mythological motifs related to Komi traditions. In order to generate favourable conditions for contacting the spirit of the cellar, players make some changes in the room: they curtain windows in the house, creating twilight as the most suitable environment for the encounter with supernatural forces: 
Ӧшиньяссӧ тупкалал, асьнім пӧлате каям. Коді бедь босьтас, коді пурт, кокалюкаяс, ся горзал: Кос петук, nem, nem! $!^{14}$
We would close the windows and climb onto the sleeping bench. Some of us would take a stick, or a knife, or a fire iron, and then we would shout: Dry / Skinny cockerel, come out, come out!

Children would introduce some destructive elements into the game experience which are specific for other ritual and transitional calendar and life situations: turn icons in the icon case upside down, just like while fortune-telling (Semyonov 1991: 65); turn fur coats inside out or put on some disguises similar to those worn before Christmas (Nesanelis 1994: 56):

Вӧльи ӧшиньяс тупкаласны, ен гугӧдасны да гугапасясяснь, да кодкӧ пьрас гӧбӧчӧ, да вӧльь шуалал:

Дедушко-бедушко, петов тэ, nетов! ${ }^{15}$
We would curtain the windows, turn the icons upside down, and turn our fur coats inside out, and then someone would enter the cellar, and we would say:

Dedushko-bedushko, come out, come out!

In order to make contact with the domovoi, the sound code is also incorporated, i.e., the players bang with pounders, fire irons, oven forks, sticks, or spindles against the floor or the door of the cellar, snap with scissors, and run around with a fire iron squeezed between their legs:

Сувталасньь, ӧтик босьтас коколюка кок вож костас котравны джодж кузяьс:

Чилла Ёгор, петалль,

Чилля Ёгор, петалль!!

И сійӧ ноксигкост тіьсс чӧвтаснь гӧбӧчас коколюкасӧ и ставыс котӧртаснь - каясны паччӧрас. ${ }^{16}$
They would stand in the middle of the room, with a fire iron squeezed between their legs, and run around in circles:

Chillya Yogor, come out!

Chillya Yogor, come out!

And then, right in the middle of running around, they would throw the fire iron into the cellar and scatter, climbing the sleeping bench on top of the stove.

The invitation to taste the food (either fresh or salty water, salt, bread with butter, potatoes) offered to the domovoi can be compared with the act of feed- 
ing 'the old folks' (dead ancestors) in the house in the morning time or at the cemetery after a funeral. In addition to asking the domovoi to come out from the cellar and taste food (in one of the texts, the domovoi was asked to mow the grass in the pasture), some games also incorporate threats and lay down conditions for the spirit of the cellar in case it fails to obey the orders of the players:

Суседушка-братанушка, Чеччыв жӧ, чеччыв!

Суседушка-братанушка, Петав жӧ, петав!

Он кӧ петав,

Кӧрт коколен клёнӧдал, клёнӧдал. Петалан кӧ,

Мича паньӧн паньӧдал, паньӧдал, Выци паньӧн паньӧдал, паньӧдали. ${ }^{17}$
Susedushka-bratanushka, rise up, rise up! Susedushka-bratanushka, come out, come out! If you don't come out, we'll beat you with an iron stick, we will. And if you come out, we will feed you from a beautiful spoon, we will feed you with a spoon of butter.

Calling upon the domovoi from the cellar is accompanied by experiencing collective fear while verifying the existence of the locus of the lower world and its inhabitant:

Эсся ставныли ланьтлали. Видзӧдал - эз на пет, оз пет. Куилььсь кылмын сььлал. Сәсся

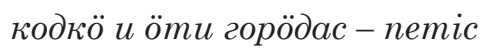
пӧ. Сәсся сія и повзыьссяс дзӧляясьљ. Господи! О-о-й, сэсся сія ставыс кутан дзебсььны. “Oü-oŭ, nemic, oŭ-oŭ, nemic”. Ömu юалӧ: “Кутшел?” Дзӧляясьљ: “Кутшел?” - “Югыљ синлиа!”“Сюра абу?” Да ӧд колӧ жӧ вӧлі челядьсӧ повзьӧдлььны тайӧн!18
Then we would all become silent. And we would look to check whether it has come out or not. We would sing a song calling it out three times, and then someone would shout out: It has come out! The smallest ones would be extremely scared. Oh my God! And then everyone would start hiding. 'Oh, oh, it's come out, it's come out!' One of us would ask: 'What is it like?' The smallest ones would ask: 'What is it like?' - 'Its eyes are glistening!' 'Does it have horns?' Yes, we were scaring the kids with that!

In the opinion of Nesanelis, 'in the localization of the domovoi (the cellar) and the playing children (the sleeping-bench), the perceptions of the spatial opposition of the up and down were represented very clearly. While for adults the perceptions of the vertical structure of a dwelling mainly unfolded through rituals related to construction, for children they were actualized in the course 
of the game' (Nesanelis 1994: 104-105). Thus, while playing, children adopt the basics of the vertical and horizontal segmentation of space.

On the one hand, in the game, children are flirting with the domovoi, calling it out from the cellar, while on the other hand, they fear meeting it. Similar behaviour is typical of game situations when players tease, befool, and delude the game leader who is invested with the features of mythological characters (one-legged, blind-folded, capacity for immobilization, moving like the wind), and at the same time they are doing their best not to be caught by him (Rassykhaev 2014: 108-109).

The name of the demonym and its main features and attributes are contained in the saying within the game - wearing red trousers, having a plait, having glistening eyes, being spotted. For example, in Kerchomya versions of the saying (Upper Vychegda tradition), the players forbid the spotted puppy (сера кыıи) to come out of the cellar. I believe that in this case, this particular domestic animal is one of the incarnations of the mythological character. In Russian folklore, the domovoi also shows itself to people in the shape of a dog. As an example, I am citing the following text from the Russian tradition proximate to the Komi: '(What is it like?) She [granny-nanny] used to say that it was shining and looked like a big dog. And where? What was it like? We never saw it.'. ${ }^{19}$

There is no doubt that the game image of the domovoi incorporates both the mythological practices of adults and children's perceptions of the invisible spirit. It can be assumed that the perceptions of the children concerning this character from the lowest mythology are also based on traditional intimidation of children using the domovoi. Such intimidation aims at nurturing children and keeping them from injuries that children can get as a result of falling into the cellar. The cellar was not only a place where food was stored (bread, baked goods, potatoes, etc.), but also a place with an increased risk to children.

In some traditions, calling upon the spirit of the cellar transformed into intimidating children. An informant from the village of Bolshelug remembered her childhood when, once on a winter day, she was invited to a house next door to call upon дедё-бедё, and asked to climb the sleeping bench on top of the stove. After calling for the domovoi, a monster wearing rags, a hat, and a beard stepped out of the cellar, which scared away the kids. Later on the children recognized the girl next door in that monster. They believed that if the domovoi caught a child, it would fall asleep for good. ${ }^{20}$

The game of calling upon the domovoi was forced out of the game repertoire in post-war years, but it was ultimately forgotten among Komi children in the 1970s. The next stage of this children's game was playing by the rules. Today only stories about how this game used to be played before circulate. For example, this is how a student of Syktyvkar State University describes this game according to her grandmother (ьљжыд мам): 
Ная челядь чукӧр чукӧртчаснь керкаас, кодлӧн ьцжыдъясыс абуӧсь. Сэсся занавесъяссӧ ставсӧ вешталасны, мед пельљ вӧлі керкаас. Эсся кутшӧмкӧ мортӧс, но тоже пудиясясны, ӧти мортӧс пасьтӧдасны гӧна пасьӧн, и пырас сійӧ гӧбӧчӧ. Эсся гӧбӧчсӧ сиптасныь. Сэсся сэн мыцйкӧ шаманитасны, ог тӧд, мыйкӧ шуаласны, шуаласны. И сійӧ кор петӧ, сійӧ, сэн жӧ ичӧт челядь тшӧтш ворсӧны, ичӧт челядьыс пӧ зэв ёна вӧлі бӧрдӧньь и котралӧны керка пасьталаас. И этія, кодӧс пӧ суас, сійӧс пӧ вӧлі гӧбӧчас и пыртас. Чукӧртӧ ӧтикан. Сэсся коді кольӧ, сэсся сійӧ гӧна пасьнас пасьтасьӧ.. ${ }^{21}$
They, children, would gather together in the house of a child whose parents were not [at home]. They would close all the curtains so that it would be completely dark in the house. Then they would have a tossup and choose a person and put a fur coat on him, and he would enter the cellar. Then they would close the cellar door. They would tinker a little, I don't know if they were saying something. And when he stepped out of the cellar, he would play with the smallest kids, but they would cry out loud and run around the house. And they used to say that he would take the ones he caught down to the cellar with him. He would take them one by one. And then the one who was left would put on a fur coat.

In the context of experiencing collective fear, the game under consideration is close to the magically playful calling upon neo-mythopoetic characters (the Queen of Spades, a Dwarf, devils, etc.), which is common among modern schoolchildren, including the Komi schoolchildren. For the participants in the 'ritual', which also takes place in the darkness and with no adults around, it is important to make contact with supernatural creatures, using a mirror, and to find traces of their presence in the room (Novitskaya \& Raykova 2002: 44). They are different from calling upon the domovoi in the Komi tradition in that during the modern ritual, a wish is made, which resembles a kind of a hypnotic session that ends with breaking a mirror into pieces or burying it.

\section{THE SAYING IN THE GAME}

Every description of the game includes a verbal accompaniment, which consists of a poetic address to the domovoi and a call for it: to come out from the cellar, to taste food - bread with butter and salt, water. 
In spite of the fact that in some descriptions informants use the lexis that refers to the group singing of these lines (челядь артельӧн сьылӧньь 'children sing in chorus'; а сьылали тайӧ 'and this is what we sing'; пондал сьыны челядь чукар 'we, a whole passel of kids, start singing'); in the comments, informants most often talk about saying those lines: ставніс шувалэні 'everyone says', дедушкоӧс корим 'we called the old man', челядьдырйи шулім 'in the childhood, they said', войдӧр вӧлі чуксалласнь 'we used to call it upon', ся горзал 'then we would shout out loud'. What is more, one and the same informant can use the lexis referring both to singing and saying:

Сәсся тай кутан шуны:

Суседушка-вӧседушка, Чилье-чилье, петав, петав!

[...] Тая вӧлі сььланкьвиясьљ, век вӧлі сььллӧны. ${ }^{22}$
Then we would say:

Susedushka-vosedushka, Chilye-chilye, come out, come out! ... Those were the songs, we would always sing them.

The uncertainty related to the way of uttering the texts (singing or saying them) proves the opinion expressed by Aleksandr Belousov, who said that in folklife culture, there is text diffusion and no clear separation between game refrains and game sayings: 'one and the same text can exist both in the form of a refrain and of a "rhyme" / "a saying" (Belousov 1989: 12).

\section{CONCLUSIONS}

The analysis of the descriptions of the game of calling upon the domovoi in the Komi tradition, presented in this paper, allows the borders of existence of this children's game to be expanded. It was widespread not only among the Komi peoples living on the shores of the basin of the Vychegda River (with the tributaries of the Vishera, the Vym, and the Sysola), but also among the northern Komi-Permiaks in the traditions of Kosinsky District. This game is unique and has no parallels in the traditions of other peoples. The image and terminology pertaining to the domovoi addressed in the game contain some perceptions that are similar to 'adult folklore', but quite often the addresses to the character called upon take on the features of 'childishness' (diminutive forms, reduplication, personal names). While playing, children actualize numerous ontological perceptions of the nature of fear, the essence of a mythological character, the binary 'friend/foe' opposition, and the vertical spatial structure. 


\section{ABBREVIATIONS}

SA Komi SC - Scientific Archive of the Komi Scientific Centre of the Ural branch of Russian Academy of Sciences

NMKR - National Museum of the Komi Republic

FDA - field data collected by the author

FA of SSU - Folklore Archive of Syktyvkar State University

\section{NOTES}

1 A protective house spirit.

${ }^{2}$ It is curious that instead of children, young men take part in the 'game', while mythological perceptions of the domovoi bringing gold and silver have strong parallels in superstitious Russian prose. For example, in the village of Nyuchpas in Koygorodsky District in the Komi Republic a popular belief was recorded, which had been told by the ancestors of the Russians who had moved here from the Vologda, Vyatka, and Kostroma governorates, which said that if you touch a domovoi, it will pour out silver or gold (Lobanova \& Nizovtseva \& Rassykhaev 2014: 27, 41): 'We had this old lady Shevelikha. She would give us a fright; we would be so afraid to come out of the house. "He is coming, she said, he is going to get you ... (How did she say that...?) the domovoi is coming, and if you touch him, he will pour out gold". And we would walk around looking for him. But no one could ever find him anywhere' (recorded by A. Rassykhaev in the village of Nyuchpas, Koigorodsky District, Komi Republic, on 4 June 2011 from G. N. Mikhailova, born in 1928 (FDA)).

${ }^{3}$ An ort is a mythological spiritual counterpart of a human being (Rochev 1985).

4 Recorded by A. Agafonova in Syktyvkar in 1935 (NMKR: KP-12484. L. 157 ob.).

5 Recorded by E. Guliaev in the village of Derevyansk, Ust-Kulomsky District, in 1963.

${ }^{6}$ Recorded by M. Sakharova in the village of Pozheg, Ust-Kulomsky District, on 26 March 1963, from P.P. Luzhikova (SA Komi SC: F. 1. Op. 11. D. 227. L. 204).

$7 \mathrm{Pi}$-pi-perhaps the desemantisation of the word nuny 'aspen' took place.

8 Iva Shor in this context might be a nickname of a fellow villager.

9 I gratefully acknowledge Elena Fedoseeva, a research fellow from the Institute of Language, Literature and History of the Komi Scientific Centre, for providing me with advice concerning Komi-Permiak dialectology.

${ }^{10}$ Recorded by A. Rassykhaev in the village of Churaki, Kosinsky District, Komi-Permiak Okrug, Perm Krai, on 16 July 2011, from V.V. Fedoseeva, born in 1928 in Churaki (FDA).

${ }^{11}$ Recorded by Y. Rochev in the village of Kerchomya, Ust-Kulomsky District, in June 1977, from E.F. Tarabukina, born in 1930 (SA Komi SC: F. 5. Op. 2. D. 218 a. L. 191. No. 80. L. 191). 
12 Recorded by A. Rassykhaev in the village of Puksib, Kosinsky District, Komi-Permiak Okrug, Perm Krai, on 17 July 2011, from N.S. Fedoseeva, born in 1932 in Puksib (FDA).

${ }^{13}$ An exception of a description of the game recorded in the village of Kerchomya in Ust-Kulomsky District: the domovoi is called upon by saying 'Сера бубыль, nem, nem, nem!' (Spotted bubylya, come out, come out!) (Paniukov \& Savelyeva 1999: No. 98).

${ }^{14}$ Recorded by N. Loskutova and G. Baraksanov in the village of Ozel, Syktyvdinsky District, on 8 December 1965, from K.I. Lytkina, born in 1898 (SA Komi SC: F. 1. Op. 11. D. 264. L. 131).

${ }^{15}$ Recorded in the village of Male, Pozhegodsky Rural Municipality, Ust-Kulomsky District, in 1995, from N. S. Martiushev, born in 1938 (FA of SSU: 1213-3).

${ }^{16}$ Recorded in the village of Pomozdino, Ust-Kulomsky District, from P.V. Ignatova, born in 1921 (FA of SSU 1214-19).

${ }^{17}$ Recorded by Y. Rochev in the village of Derevyansk, Ust-Kulomsky District, in June 1977, from I.A. Guliaeva, born in 1910 (SA Komi SC: F. 5. Op. 2. D. 218 a. L. 212. No. 88).

${ }^{18}$ Recorded by Y. Rochev in the village of Derevyansk, Ust-Kulomsky District, in June 1977, from I.A. Guliaeva, born in 1910 (SA Komi SC: F. 5. Op. 2. D. 218 a. L. 212-213. No. 88).

${ }^{19}$ Recorded by A. Rassykhaev in the village of Nyuchpas, Koygorodsky District, Komi Republic, on 4 June 2011, from G.N. Mikhailova, born in 1928 (FDA).

${ }^{20}$ Recorded by A. Rassykhaev in the village of Bolshelug, Kortkerossky District, on 16 June 2015, from L.M. Gabova, born in 1927 (FDA).

${ }^{21}$ Recorded by A. Rassykhaev in Syktyvkar on 20 December 2013, from V.S. Lodygina, born in 1995 in Kerchomya, Ust-Kulomsky District (FDA).

${ }^{22}$ Recorded by Y. Rochev in the village of Anyb, Ust-Kulomsky District, in June 1977, from A.D. Paniukova, born in 1894 (SA Komi SC: F. 5. Op. 2. D. 218 a. L. 308. No. 145).

\section{REFERENCES}

Belousov, Aleksandr 1989. Detskii fol'klor: lektsiia dlia studentov-zaochnikov. [Children's Folklore: A Lecture for Extramural Students.] Tallinn: Tallinnskii pedagogicheskii institute.

Lobanova, Liudmila \& Nizovtseva, Svetlana \& Rassykhaev, Aleksey 2014. Otchet o polevykh issledovaniiakh fol'klornykh ekspeditsii v pos. Niuchpas Koigorodskogo raiona i pos. Niuvchim Syktyvdinskogo raiona Respubliki Komi v 2011 godu. [Report about Field Researches of Folklore Expeditions to the Settlement of Nyuchpas of Koygorodsky District and the Settlement of Nyuvchim of the Syktyvdinsky District of the Komi Republic in 2011.] Nauchnyi arkhiv Komi NTs: F. 5. Op. 2. D. 804. 
Nesanelis, Dmitry 1989. Starinnaia igra detei komi "görd gacha": opyt semanticheskogo analiza. [The Ancient Game "görd gacha" of the Komi Children: Semantic Analysis.] Genezis i evoliutsiia traditsionnoi kul'tury komi. Trudy IIaLI Komi NTs UrO RAN, Vyp. 43, pp. 80-89.

Nesanelis, Dmitry 1994. Raskachaem my khodkuiu kachel': Traditsionnye formy dosuga sel'skogo naseleniia Komi kraia (Vtoraia pol. XIX-pervaia tret'XX vv.). [We Are Swaying a Quick Swing: Traditional Leisure Forms of Country People of the Komi Region (The Second Half of the 19th - the First Third of the 20th Centuries).] Syktyvkar: Resp. tsentr nar. tvorchestva.

Nesanelis, Dmitry 1999. Detskie igry. [Children's Games.] In: Traditsionnaia kul'tura narodov Evropeiskogo Severo-Vostoka Rossii. Etnograficheskaia elektronnaia entsiklopediia. Available at https://ethnokomi.ru/folk/komi/138.htm, last accessed on 10 May 2019.

Novitskaya, Marina \& Raykova, Irina 2002. Detskii fol'klor i mir detstva. [Children's Folklore and the World of Childhood.] In: M. Novitskaya \& I. Raykova (comps.) Detskii fol'klor: Biblioteka russkogo fol'klora. T. 13. Moscow: Russkaia kniga, pp. 5-53.

Paniukov, Anatoly \& Savelyeva, Galina (comps.) 1999. Traditsionnaia kul'tura komi: Etnografiia detstva. Materialy fol'klorno-etnograficheskikh ekspeditsii 1995-1998 gg. [Komi Traditional Culture: Childhood Ethnography. Materials of Folkloric and Ethnographic Expeditions 1995-1998.] Syktyvkar: Gosudarstvennyi tsentr narodnogo tvorchestva Ministerstva kul'tury Respubliki Komi.

Rassykhaev, Aleksey 2014. Detskii igrovoi fol'klor komi: zhanrovyi aspekt. [Komi Children's Game Folklore: Genre Aspect.] Syktyvkar: Komi NTs UrO RAN. Available at https://illhkomisc.ru/wp-content/uploads/2014/11/rassyxaev.pdf, last accessed on 10 May 2019.

Rochev, Yuri 1972. Detskii fol'klor komi. [Komi Children's Folklore.] Diss. na soiskanie uchenoi stepeni k. filol. n. Ogarev Mordovia State University. NA Komi NTs. F. 5. Op. 2. D. 129.

Rochev, Yuri 1979. Detskii fol'klor komi. [Komi Children's Folklore.] In: Istoriia komi literatury. [History of Komi Literature.] T. 1. Syktyvkar: Komi knizhnoe izdatel'stvo, pp. 195-224.

Rochev, Yuri 1985. Traditsionnye predstavleniia komi ob orte i ikh transformatsiia v sovremennosti. [Traditional Images about the Komi ort and Their Transformation in the Modernity.] In: L. Zherebtsov (ed.) Traditsiia i sovremennost'v kul'ture sel'skogo naseleniia Komi ASSR. Trudy Instituta iazyka, literatury i istorii Komi filiala Akademii nauk SSSR, Vol. 37. Syktyvkar: Komi filial, Akademiia nauk SSSR, pp. 57-70.

Semyonov, Viktor 1991. Traditsionnaia dukhovnaia kul'tura komi-zyrian: ritual $i$ simvol. Uchebnoe posobie po spetskursu. [Traditional Spiritual Culture of the KomiZyrians: Ritual and Symbol.] Syktyvkar: Syktyvkarskii gos. un-t.

Sorvacheva, Valentina \& Zhilina, Tatyana 1971. Obraztsy komi-zyrianskoi rechi. [Samples of Komi-Zyrian Speech.] Syktyvkar: Komi filial AN SSSR.

SSKZD 1961 = Sravnitel'nyi slovar' komi-zyrianskikh dialektov. [Comparative Dictionary of the Komi-Zyrian Dialects.] Compiled by T. Zhilina \& M. Sakharova \& V. Sorvacheva. Syktyvkar: Komi knizhnoe izdatel'stvo. 


\title{
TRADITION OF CHRISTMAS YOUTH GATHERINGS AT THE VISHERA RIVER (KOMI REPUBLIC)
}

\author{
Galina Savelyeva
}

Senior Research Fellow

Folklore Archive, Institute of Language, Literature, and History

Komi Science Centre, Russian Academy of Sciences, Russia

Email: galsav69@mail.ru

\begin{abstract}
The article deals with the tradition of Christmas youth gatherings within a narrow local tradition that exists at the Vishera River (a tributary of the Vychegda River, the Komi Republic). The structure of the research includes the following sections: the history of studying the ethnocultural specific character of the Komi at the Vishera; a combination of the circle dance and a game; some aspects of the existence of borrowed songs; merrymaking entertainment and disguises; and the transformation of the ritual (merrymaking of youngsters). Different stages of the existence of this ceremonial complex, which are historically determined, are represented: traditional, adolescent from the Soviet period, and the modern one.
\end{abstract}

Keywords: Christmas, Komi-Zyrians, song folklore, youth gatherings

\section{INTRODUCTION}

The subject of the research is the tradition of Christmas youth gatherings, i.e., merrymaking within one of a group of narrow local Komi traditions. Defining the term 'merrymaking', Tatyana Bernshtam (1978: 65-66) singles out three main components of the term: 1 ) a type of the youth festival that is held in summer and winter periods of the calendar year; 2 ) doing a circle dance and singing specific songs, in which young men and women take part; the merrymaking composite may include traditional games, such as 'race-and-catch', etc.; 3) dominance of the wedding and matrimonial topic ('pre-wedding composite'). These three aspects can be complemented by the fact that merrymaking was a communal activity and a ritual action, in which all age and sex groups would take part, and each of them had its own part to play (spectators, singers, leaders, those in disguise, participants in rituals and performances, etc.). 


\section{HISTORY OF RESEARCH ON THE ETHNOCULTURAL SPECIFIC CHARACTER OF THE VISHERA KOMI}

The Vishera River (Bucep in the Komi language) is the right tributary of the Vychegda River (Эжва). Its territory is a part of the Kortkerossky District in the Komi Republic and includes the villages of Nivshera (Одьљ), Bogorodsk (Висер), and Bolshelug (Ыджыдвидз) with their adjacent settlements. Ethnographers associate the beginning of the formation of the Upper Vychegda group of the Komi-Zyrians with the history of settlement of the banks of the Vishera. The first records date back to the second half of the fifteenth century and contain information about the first settlers from the Vym River (Елва). The distinctive character of this tradition is highlighted in a number of ethnographic and folkloristic studies (Zherebtsov \& Lashuk 1958; Teryukov 1983; Panyukov 2004; Panyukov \& Savelyeva 2006: 274-277; Lobanova \& Rassykhaev 2013, $2016,2017)$. The linguistic research also bears witness to the dialectally specific character of the speech of the population of this area, which is distinguished as a separate subdialect of the Upper Vychegda dialect of the Komi language (Sorvachova \& Sakharova \& Gulyaev 1966: 7, 9).

Field research in Nivshera, Bogorodsk, and Bolshelug has almost a centuryold tradition. The first folklore records in this area were made by Victor Savin and Pavel Anisimov in 1926. The description of their trip is represented in one of the feature articles of Savin (1926). In 1938-1939, Ivan Osipov was working at the Vishera River. Some examples of song and fairy-tale folklore were recorded by him in their sound version. ${ }^{1} \mathrm{~A}$ collection of stories called Висер вожса сььланкыьвля да мойдкььвљяс (Songs and Fairy Tales of Vishera Vicinity) (Osipov 1941) was published on the basis of the material collected in the course of field research. In 1954, the songs of Bogorodsk were recorded by Sergey Piatiev (Kuznetsov \& Lobanova 2014: 77-78).

While the records made in the first half of the twentieth century were limited to separate folklore samples, the subsequent field research involved a purposeful frontal collection of field material. In 1962-1964, studies of the Vishera tradition were made by Prometey Chistalyov and Galina Muravyova. ${ }^{2}$ In terms of the amount of recorded sound material, their field research has been the most large-scale and fully representative of the song tradition of the Vishera, without any kinds of presets with regard to the language-based selection of recorded material. The recordings of songs in Bogorodsk and Nivshera are also available in the linguistic material collected by the Estonian researcher Anu-Reet Hausenberg in 1968 (Kuznetsov \& Lobanova 2014: 79-80). In 1978, a group of researchers conducting linguistic and folkloristic field research, with the participation of Yuri Rochev and Vladimir Lyashev, was working in the villages of 
Nivshera and Lymva. ${ }^{3}$ In 1994-2000, a number of field studies were conducted by Anatoly Panyukov and Galina Savelyeva. ${ }^{4}$ In 2010-2016, the Vishera tradition was researched by Liudmila Lobanova and Aleksey Rassykhaev.

At present, Nivshera holds a unique position on the cultural map of the republic. Some of the elements of calendar rituals are still alive here and exist within the living tradition till this day. The traditional song repertoire is also preserved, although not nearly to the extent as full as compared with the material dating back to the middle of the past century. Here Christmas merrymaking took place up until the 1960s. Then, after a short break, the festivities were resumed at the village community centre, with all of the main action elements being preserved. In recent years, Christmas merrymaking is mainly associated with the activities of the local folklore band 'Sipertas' (headed by Maria Popova).

\section{COMBINATION OF A CIRCLE DANCE AND A GAME}

The main content of Christmas merrymaking at the Vishera is related to acting out the scenario involving a circle dance and a game. The songs that were sung within that scenario (рӧштво сьыланкьвъяс 'Christmas songs') were widespread throughout Kortkerossky District. There were no other recordings concerning such a strict confinedness in any other areas. The same thing can be said about the geographic range of the existence of the name of the merrymaking process - чивильтэл, which was only common in Bolshelug, Bogorodsk, and Nivshera. The term чивильтэл is related to the first rota named Чивиль-чивиль воробей 'Chivil'-chivil'5 the sparrow', which was sung while the participants were forming a circle.

The scenario is acted out in the following sequence: circle dances, 'braiding and unbraiding the rope', the 'row-to-row' circle dance, refrain songs (that helped to find matches, see below).

When singing in a circle, the participants simply walked in circles, stamping their feet and holding their hands. In addition to the song Чивиль-чивиль воробей, the songs sung in a circle also included Здравствуй милова 'Неllo milova ${ }^{6}$ ' (milova < darling), Изу лесу 'From the forest', Я вечора молодова 'I'm young in the evening', and others. These songs have a relaxed rhythm and the strophics typical of circle songs, which consists of four verses corresponding to four strings of notes (in the type of AABB). In musical terms, the second part of the verse has a faster pace, which is achieved by splitting 1/4 into 1/8.

According to the description of Christmas gatherings in Bogorodsk, which was given on the basis of the performance acted out at the request of the collector, songs sung in circles were divided into fast and slow ones. 
“Куил луннад вед мыйке вӧлі сьылам. Майбыр, гажид вӧлі. Питшегад пирог либе шаньга сюйиштан да котэртан войпук вылад. Детинаяс вӧлі пять кӧпеек сетэны керкатэ войпукні медалігад. Сэсся рытыыьбыц сьылам да ворсал. Кор бурлакъястэ мичаджик ныькед сьылэдан, любеәд вӧлі...” С этили словали певиць мои поднялись с мест и встали в круг. У. Ф. Калистратова запела "Чивиль" и пошли по кругу. А затем последовали "Я на два", "Чипан ладэн" [не переводится - G. S.], "Я вечера молодова”. Все это пели спокойно и плавно, ходили по кругу. Но вот запели "Я скажу, скажу", все остановились и начали петь быстрыл телпол, при этол топали ногали и похлопььвали в такт рукали. "Вдоль по бережку" так же исполнили, а зател запели "Заплетой”. Стали "плести веревку".7

'Within three days something was sung. It was fun. You would put a pie or a shan'ga $a^{8}$ in your bosom and run off to a party. Lads would pay five kopeks to rent a house, and we would play and sing all night. It was such a nice thing when you matched a young man with a beautiful girl through a song...' With that my singers rose up from their places and stood in a circle. U. F. Kalistratova started singing "Чивиль" and we started moving in circle. The first song was followed by "Я на два", "Чипан ладэн" [untranslatable - G. S.], “Я вечера молодова” [I’m young in the evening]. They sang all of those songs very peacefully and smoothly and walked around in circles. But when they started singing "Я скажу, скажу” [I will tell you], everyone stopped and started singing fast, stomping their feet and clapping their hands in tune. Then they sang "Вдоль по бережку" [Along the coast] and "Заплетой” [Braid it]. And they started 'braiding a rope'.

Fast songs, in addition to the aforementioned "Я скажу, скажу", also included "Под горою Ваня топится" (Ваня < баня 'sauna'; The sauna is heated at the bottom of a hill), "Мишчую да миленькой" (misspelled, untranslatable), "Старечник" (Old man), etc.

The next type of a circle dance is 'braiding a rope', which was danced to the tune of "Заплетай". The dancers held hands. The first pair of people at the end held their hands up high and made the 'gates' through which all other dancers had to pass, starting from the furthest end of the line. Then the next pair of people made the 'gates', and so on, until there was a live spiral: dancers stood one after another with their right hand on the left shoulder and holding the left hand of a person standing at the back, while the left hand was stretched forward onto the left shoulder of a person standing at the front. Then the dancers started 'unbraiding the rope' while singing the song "За гур девица" (A girl 
from behind the mountains). The song was repeated for every single dancer in the circle dance:

“Заплетой” in the beginning, and then we would sing this song as many times as was needed, let it be one hundred or two hundred people. /.../ Then we started singing 'За гур девица', until the game stopped [until all of the dancers in the circle were 'unbraided' - G. S.]. ${ }^{9}$

In addition to the traditional designation of this choreography as 'braiding/ unbraiding the rope', a peculiar terminological adaptation of 'locking/unlocking' was recorded in Nivshera:

We would come in a circle and sing “Заплетай”. If there were thirty people, we would sing it thirty times. You walk in a circle and then come nearer, then they would lock you in, walking around the whole time. Then they would lock another one in. And take by a shoulder. Then they would sing it again and lock another one in, singing “Заплетай” the whole time. Then, when everyone was 'locked in', they would walk in a circle, about three times. Then they would start unbraiding. "Загур девица" - the unbraiding song. They would unlock thirty locks, walking around in circles and dancing. ${ }^{10}$

Then there was a circle dance to the song "Ми пе тавун кӧдзалал, кӧдзалал” (Today we were sowing, sowing), which is an adaptation of the translation of the song 'We were sowing millet', which is widespread in the Russian tradition (Krasnopolskaya 1977: 135, 136; Bolonev \& Melnikov 1985: 103, 104, and others). The dancers would stand in two lines opposite each other. The lines approached each other and then came back. The song was sung in the form of a dialogue with the refrain "Ай ладy, ладy" (untranslatable). In the first part, the topic of sowing was dealt with in the form of questions and answers:

- Мыцйӧн жӧ да кӧдзалад, кӧдзалад,

Ай ладу, ладу, льєйӧн жӧ, мьийӧн жӧ?

- Вӧӧясӧн пӧ кӧдзалал... ${ }^{11}$

- Kыıсь бара пӧ вӧӧясыс?...

- Вӧӧястӧ ли куталам...

- Мыйӧн же ті куталад?...

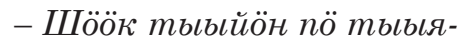

лал...

(Osipov 1986: 41)
- What are going to use for sowing, sowing?

Ai ladu, ladu, what are you going to use?

- We are going to use horses ...

- Where will the horses come from? ...

- We will catch the horses ...

- How will you catch them? ...

- We will catch them with a silk net ... 
Then the singers would sing about sowing the millet they have bought. Then about buying and selling girls. One of the parties wanted to buy a girl, and the other one would set the price: the 'average' girl cost one hundred roubles, 'another' one - one thousand roubles, and the 'furthest' one - two hundred roubles. In the end, a girl would move from one line (party) to the other:

- Миян пӧ ныbы соді...

- Now we have more girls ...

- Миян пӧ тавун ныьь чині... - Now we have less girls ...

(Osipov 1986: 42)

In the Soviet period, the dancers in the circle were divided into 'collective farmers' and 'communists'. The song was also adapted respectively:

- Комлунистьяс, дами тіян - Communists, we are coming to дінэ волал!... you! ...

- Колкозникъяс, мыйӧн жӧ ті - Collective farmers, how are you локтаннід?...

- Колмунистуяс, ми вӧд вӧвдясӧн локтал...

- Колкозникъяс, кутшӧл нӧ же вӧвбясьд?...

- Колмунистьяс, вӧвъясіс тшая кокась...

- Колкозникъяс, да лиянлі

ӧти морт колэ... coming? ...

- Communists, we are coming by horses ...

- Collective farmers, what kind of horses do you have?...

- Communists, with the white brush

- Комлунистьяс, да кодэс же mi босьтаннід?...

- Колкозникбяс, да миянлі этія колэ...

- Миян полкніл чині-чинічині...

- Миян полкніл соді-содіcoдi...

- Миян полкніл шолаясшолаяс... ...

- Collective farmers, we need one person ...

- Communists, who do you take?

...

- Collective farmers, we need this one ...

- That's one up for our side

...

- That's one down from our side

...

- There's a sour one up for our side ... $^{12}$

After the part with the circle dance, couple-making songs pöштво сььлӧдчанкьвъяс were sung: "Сирчунь-бирчунь” (untranslatable), “Ылььньллььн тшыьн тшыналӧ” (Far, far away the smoke is smoking), "Bьлльысь пӧжӧмӧй да Mатрёнаӧй"(Newly-minted Matryona), etc. Couple-making songs are one of the types of game forms of a youth wedding - marrying off through 
a song (Kaneva 1998: 112). The main attribute of this group of song and game folklore is naming a specific boy and girl by their name and patronymic. Merrymaking participants stood in a circle, and the pair that was sung about stood in the centre, or everyone was sitting in their places, and the pair was standing in front of everyone and dancing to the song:

They would be dancing in the centre of the circle, no matter what, anything they could. Sometimes paturlikas'öny [literally 'turning somersaults, cavorting'], the lads. And the girls were dancing around, just any way they could. ${ }^{13}$

At the end of the song, the boy and the girl would hug and kiss each other:

They sang them into couple, then another / pair/. If they liked each other, they would hug each other, if they didn't, they wouldn't. ${ }^{14}$

The young man had to kiss the girl; they would step away into the corner and hug each other. Or do nothing. Just give each other a half-hug. ${ }^{15}$

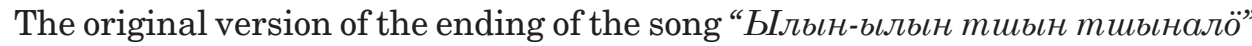
was recorded in Nivshera. Among the Komi, this song was universally widespread:

Ыльц-ьлььн тшын тшыналӧ, Far, far away the smoke is smoking, Матьıн-латьљн дуб дубалӧ, Дуб улас нёль кер,

Нёль кер улас нёль кор,

Нёль кор улас нёль тусь,

Öти тусь - Kamя,

Мӧд тусь - Микулай, Nearby the oak is growing bard, There are four logs under the oak, There are four leaves under the four logs, There are four berries under the four leaves, One berry is Katya,

Койлӧд тусь - Матвеевна, Another berry is Nikolai, Нёльӧд тусь - Елизарович. The third berry is Matveevna, The fourth berry is Yelizarovich.

The Nivshera adaptation continues:

Катясӧ да Микулайсӧ

Гидӧ сюял - игналал, Идзас волес вольсалал да, Асылӧдзысс сэн видзалал. ${ }^{16}$
We will put Katya and Nikolai into a cowshed and lock them in, We will spread out a straw mat, And keep them there until morning. 
While that song was sung, everyone sat, and the pair which was sung about walked around, holding each other's hands and hugging each other. Then they would ask a boy and a girl: 'Will you go into a cowshed?' If the boy and the girl liked each other, they would walk away, hugging and kissing. If they did not, they would sit back down.

\section{SOME ASPECTS OF THE EXISTENCE OF BORROWED SONGS}

Festive gatherings of the Komi youth, just like the complex of Christmas rituals on the whole, date back to the northern Russian tradition. This is why the majority of the songs sung during merrymaking is represented by borrowings

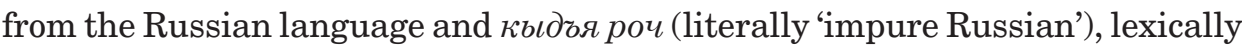
misspelled units. ${ }^{17}$ The preservation of the Russian-language borrowings in calendar rituals is typical of all Komi traditions. The trend of conserving the songs assigned to the ritual is accompanied by specific mechanisms of language comprehension and secondary etymologization of borrowed texts. Thus the beginning song 'Chivil'-chivil' the sparrow' gets an original ending:

Ешиӧ жӧник тотара,

Тотара ли понтара

Ешё сель четверу,

Четверу ли шестою.
Still the groom totara,

Totara or pontara

Seven more or four, four or six.

The emergence of a number series понтара (apparently from Russian полтора 'one and a half'), сель (seven), четверу (four), шестою (six) is related to the idea of structuring and distinguishing a youth group (the main participants of merrymaking), which is engrained in a circle dance. For comparison, we could describe an ӧктысян 'gathering' circle dance that is widely spread both among the Russians and the Komi. To the accompaniment of certain songs, a young man selected a girl, and a girl selected a young man, etc., until a large circle was gathered. The count in the text as well as the actional phasing of gathering were aimed at organizing the youth space for merrymaking. Apparently this is why the song 'Chivil'-chivil' the sparrow' was sung at the beginning of the circle dance and the game part, and a derivative term made from the name of the opening song entrenched itself as a denomination of the entire song and game complex - чивильтӧли.

In their essence and content, the songs sung in a circle dance have something in common with lyrical long drawn songs. In spite of linguistic deformation, it is quite easy to single out key images in them, through which the topics of 
parting, loneliness, unhappy marriage, etc. are actualized. For example, in the song “Здравствуй милова" (Hello, my dear), the subject matter determined the following lexical stream: to no one, my dear - under the cradle in tears all alone - without me - without you - without you, my last single friend. This diverse imagery is united by the meaning of the absence of someone or something. Below is a text with the approximate reconstruction:

\begin{tabular}{|c|c|c|}
\hline Здраствуй милова... & Hello, my dear... & \\
\hline Здраствуй милая & Hello, my darling... & \\
\hline корошая моя... & The black-browed... & $<$ black-browed \\
\hline Черной бравой... & The black-browed, & \\
\hline Чернобравоя & the good one... & \\
\hline порядошная... & Yus' kok to no one... & $<$ oh so; yus' kok \\
\hline Юсь кок некому... & Yus' kok to no one, & literally 'swan \\
\hline Юсь кок неколу & my dear... & foot' \\
\hline голубушка моя... & Sgolov'yushki & $<$ sgolovyitse (pil- \\
\hline Сголовьюшки... & Sgolov'yushki under & low) sunk in tears \\
\hline Сголовьюшки потан & the cradle, in tears... & $<$ blanket \\
\hline улььн во слезах... & I'm lying down all on & became covered \\
\hline Один я лечь... & my own... & with hoarfrost \\
\hline Один я лечь три зачел & I'm lying down all on & \\
\hline девала... & my own, why three... & \\
\hline Три гӧлубчик... & Three, my dear... & $<$ will fondle and \\
\hline Три гӧлубчик три & Three, my dear, & caress \\
\hline ласкачот без меня... & three laskachot & \\
\hline Без тебтя... & without me... & \\
\hline Без тебъя мой друг & Without you... & \\
\hline последний колостой... & Without you, my last & \\
\hline Здраствуй милова... & single friend... & \\
\hline Здраствуй милая & Hello, my dear... & \\
\hline хорошая моя. ${ }^{18}$ & Hello, my darling. & \\
\hline
\end{tabular}

A dramatic example of linguistic re-thinking of a text in the Russian language is the formula потан ульн 'in tears'19 'under the cradle in tears' from the original 'the pillow sunk in tears'. The emotional plan of the Russian adaptation (night sadness, melancholy) in the Vishera adaptation is transformed into an image of a woman crying near the cradle, which makes the aspect of the heavy burden of a woman even more vivid in terms of its actualization. 
The outcome of this phonetic transformation is one of the formulas in the song "Изу лесу" (From behind the woods), which stands out against the background of lexically unsubstantiated string-like arrangements, i.e., война вэли 'waged a war' (the original version was, apparently, 'beating-thrashing soundly'). The following comment is very illustrative of the significance of the motif of war that emerged as a result of transformations: “Изу лесу” was sung by women, including young women, whose men were at war, they danced with zest. Not only us, the little ones, but women, too. When they came home from work in the evenings.' 20

Along with the topic of parting, these texts also include the topic of an encounter and the related motif of the reunion of a boy and a girl. Some adaptations of the song “Здравствуй милова" run on and end with a 'kissing' formula: 'kiss three times'.

In the song "Изу лесу" the closing formula includes the verbal stream that is associated with the motif of walking in circles: we walked - we walked aroundwe came back - we walked in circles. From that perspective, this circle song can be correlated with the circle dance, in which an interchangeable pair to walk around - to stroll is included in the scheme: looking for a mate - finding a mate-consolidating the pair (for example, the storyline of a tsar's son is very popular both in the Russian and the Komi traditions).

Couple-making songs were evolving independently both in terms of linguistics and folklore-poetics. The two opposite ends can be marked with regard to formal and semantic organisation of these texts. There are songs that constitute deformed texts, in which it is not possible to distinguish a conceptual core even at the level of individual words. In this context, the names themselves are endowed with distinct meaning, by means of saying of which the process of 'marrying off' takes place. On the other hand, if we compare couple-making songs with other groups of game songs, it is the former that incorporate the concentration of the main block of texts in the Komi language. Moreover, the majority of them do not result from the transfer of individual Russian plots into the Komi language. Ritual semantics, conceived and comprehended within the context of tradition, have transgressed into poetic forms generated by culture. Some of them are stable and widespread adaptations, while the improvisatory beginning based on folklore universals is incidental to others. 


\section{MERRYMAKING AND DISGUISE-WEARERS}

Merrymaking was associated with amusement and entertainment which, similar to the Russian tradition, were meant for newcomers and were of testing and dedicative nature (Morozov 1998: 114, 115). One of them was called кӧзa льсьтӧл 'milking a goat'. One of the girls dropped to all fours, another one sat down by her side, stretching her legs under the body of the 'goat', and started miming the process of milking. Then the 'goat' would collapse on the 'milkmaid' who fell on her back with her legs up in the air. ${ }^{21}$ Another similar type of entertainment was Мӧсква видзеднь 'seeing Moscow' and it consisted in the following: ash was poured into a 'spyglass' made of paper, which was covered at one of the ends. A newcomer was asked whether he or she wanted to see Moscow, and after they had agreed and looked into the 'spyglass', ash poured into their eyes. ${ }^{22}$

Disguise-wearers were traditional participants in merrymaking in Nivshera. According to available records, they dressed up as a 'cock' (петук) and a 'sieve head' (пож юр). Two or three people dressed up as cocks entered a room: they put on a sheepskin coat and thrust a fire iron through the sleeve, which was used to 'peck' other people in the room. The sieve head was an anthropomorphic character: one person held a shoulder pole with a sheepskin coat on it above their head, and they also held a sieve up high with a headscarf on it. The disguised person was beneath the coat, the shoulder pole represented their arms, and the sieve was the head. Their main task was to frighten the players. Informants compared the sieve head to the Leshy. ${ }^{23}$

\section{TRANSFORMATION OF THE RITUAL MERRYMAKING OF THE YOUTH}

On the one hand, the field research data from recent years (since 1994) give an idea of the organizational aspects of merrymaking, and on the other hand, allow to trace the changes that were taking place in the context of the tradition of Christmas merrymaking throughout the twentieth century.

Information about merrymaking, which can be correlated with the data collected during field research in the middle of the last century in terms of completeness and integrity, was recorded in 1997 and 2000 from female inhabitants of Nivshera, who were able not only to re-create the set of relevant rituals with ease, but also constituted a sample of the 'natural' singing group. ${ }^{24}$ 
In the reports provided by other performers, Christmas merrymaking in most cases was represented as youth (children's) gatherings. The informants born in 1928-1934 mainly described the merrymaking in which they had taken part (in 1940-1950). Some informants pointed out that they were the last generation that still had чивильтӧл-type gatherings. The participation of youngsters in merrymaking was sporadic, and the main active participants were children aged 10-14. In view of a number of some external factors, the youth' merrymaking of the time was related to living in logging barracks and was held under its own inertia.

We would even come together to enjoy chivil'töm merrymaking at logging camps. We would gather together, equals in age, come into one barrack, then into another one. We were quite grown-up by that time. ${ }^{25}$

To organize merrymaking for children, usually a house was rented from lonely people or from families with many children, i.e., from those who were living in poverty and needed money. Both girls and boys took part in merrymaking:

After lunch we would start looking for a house: we would be asking our fellow villagers, one after another, both boys and girls. ${ }^{26}$

Mothers took active part in preparing their children for merrymaking:

Mother would bake pies, and we took them to chivil'töm- merrymaking. ${ }^{27}$

Mother would send us away saying: 'You must not go empty-handed to the chivil'töm -gathering'. We brought different stuff with us, someone brought pies, others brought sugar. Then we would sit all together and drink tea. ${ }^{28}$

At youth gatherings, the traditional song and circle dance repertoire was invariably acted out, while games were of the highest priority. It is on games that the informants placed the greatest focus in the majority of descriptions:

First of all, we sang "Чивиль" and stood in a circle. Then we played other games: “Кума-кула”, “Гьр юр”, until late. ${ }^{29}$

We walked to ‘чивильтны' (played чивиль). / ... / Children played “Kyлnкy.nа", hide-and-seek. ${ }^{30}$

We paid with pies and shan'gas for a house. Equals in age, we would gather together, from twelve years old. And older children would also come. We played 'чивиль' [the circle dance part - G. S.], then we played: “Телеббон” [Telephone], "Гььр юр”. Girls would put on beautiful dresses, shawls, and rush off to 'чивильтны'. ${ }^{31}$ 
Rules of the games mentioned above:

"Гьр юр"(Mortar-head). The game leader was covered with something. One of the players tapped or pushed him, and everybody asked: 'Тыр юр, код воліс?' (Mortar-head, who came here?) If the lead singer got it right, the player who pushed him replaced him.

The games "Кула-кула" (untranslatable) (and “Жель дзебан” (Hiding a chip)) are adaptations of the 'ring'-type game. According to the rules of the first game, players stood in a circle, and the blind-folded lead player was placed in the centre. Then some item was hidden in the hands of one of the players. After the question 'Kuma-kuma, who has it?', the lead player had to guess who was holding the hidden item. According to the rules of the second game, everyone was sitting, and one of the players would put a 'chip' into the hand of another player discreetly. The lead player had to guess who had the chip.

“Дзебсясян" (Hide-and-seek). This game was played in the house. The younger lead players paired up, while the older ones were on their own.

The game "Kyтасел" (Play tag) was also included in the process of Christmas merrymaking. This is how it was played: Everyone was standing in a circle; two people were standing outside of the circle, and one of them was chasing the other, trying to catch him or her; the person being chased could 'save' himself or herself by stepping in front of one of the players, after which this particular player started running away from the lead player.

The scenario of youth merrymaking also includes such a significant action element as matching pairs. Couple-making songs are sung during pair-matching, but their purpose changes, i.e., it transforms from consolidating potential brides and grooms in pairs to 'playing adults' of some kind, in which a 'funny' part was put in the forefront:

We would sing couple-making songs just for fun, if we knew who was a match, we sang them, and if we didn't, we would sing someone on purpose. ... We were teasing the lads if we knew who they were friends with. We had known many of them since childhood. We would sing all of the lads matching them with girls. ${ }^{30}$

We would sing all of the lads, who will get whom. ${ }^{31}$

A similar attitude to adult 'genres' is evident in Christmas youth fortune-telling:

We wrote the name of the groom and some other words on small pieces of paper, roll them up, walk out in the street and scatter them around, and then we looked what each one of us got. And we laughed a lot. We were twelve then. ${ }^{33}$ 
The presence of spectators was a must at merrymaking. As a rule, these were 'old women' who just watched and sang along as well as young married women who could also take part in the game. The participation of other sex and age groups in merrymaking is related to one of the most interesting innovations, i.e., saying prayers and singing sacred songs alternating with games:

- Where we were celebrating, in the same place, there were our mothers, they were not old yet, well, my age [about 67 years - G. S.], and they were saying prayers. They didn't sing those songs [merrymaking - G. S.], it was a sin for them. They were very, very religious, Orthodox, they sang many prayers.

- Christmas prayers?

- Yes, Christmas prayers, and many other prayers.

- In the same house?

- Yes. They came to watch, and when we got tired, they started singing prayers. They would milk cows, and if they had no other chores, they would come to a party in the evening. ${ }^{34}$

The prayers that were said, festive troparions, and other sacred songs represent the standing local repertoire, which is performed on holy days in honour of family icons, which are also celebrated today.

The replacement of youth Christmas merrymaking with adolescent merrymaking in Nivshera is one of the examples when new factors were mainly caused by age shifts. While the participants in traditional festive and everyday gatherings were unmarried youngsters aged 16-22, in adolescent gatherings their age dropped down to 14 years old.

Adolescent Christmas merrymaking replaces youth merrymaking, keeping the communal nature of the event. It is this particular attribute that predominates, which blurs the matrimonial idea/aspect of merrymaking. The borderline age-related status (not children yet, but not 'brides' and 'grooms' either) becomes determinant while re-thinking the role of merrymaking in the life of a group of people as a single composite of worldview and ritual perceptions: the song and game scenario is acted out in full, but with limitations that are relevant to age; the meaning of merrymaking as a prenuptial youth game is changing; it becomes possible to incorporate a stock of prayers from Orthodox holidays into merrymaking.

The conservation of rituals and certain ritual elements in children's/adolescent environment is one of the means of preserving and transforming traditional culture. It should be pointed out that in the village of Poztykeros in the same district the opposite process took place: the informants born in 1912-1916 point 
out that 'old women' gathered together at Christmas, while the youth went to the club. Consequently, two different forms of celebrating Christmas co-existed: the merrymaking that took place in accordance with the traditional scenario, the main participants in which were 'older women', and the new form of going to the club. This kind of status refocusing on Christmas merrymaking has led to a complete disappearance of the tradition.

\section{CONCLUSION}

In view of social and political conditions of the Soviet period, rural cultural life in the twentieth century mainly focused around local community centres (clubs). Throughout almost the whole area, the traditional festive and calendar cycle has been replaced with a set of rituals which were new both in content and in form. By contrast, Nivshera is a rare exception. Christmas merrymaking has not only been preserved in the memories of local old-timers, but also occupied a strong position in the system of Soviet celebrations. The chronology and amount of the data collected during field research allow to imagine different stages of existence of this set of rituals, which can be substantiated from the historical perspective: traditional, at logging camps, adolescent. At present, merrymaking is a trademark of the local folklore band and a living proof of the distinctive cultural character of the Vishera region.

\section{ABBREVIATIONS}

A - audio recording

$\mathrm{V}$ - video recording

SA Komi SC - Scientific Archive of the Komi Scientific Centre of the Ural Branch of the Russian Academy of Sciences

FDA - field data collected by the author

FA of SSU - Folklore Archive of Syktyvkar State University

FF of ILLH - Folklore Archive of the Institute of Language, Literature, and History of the Komi Scientific Centre of the Ural Branch of the Russian Academy of Sciences 


\section{NOTES}

1 Handwritten material by Osipov is archived at the Scientific Archive of the Komi Scientific Centre of the Ural Branch of the Russian Academy of Sciences: F.1. Op.11. D.36. Sound recordings are archived at the archive of sound recordings at the Institute of Russian Literature of the Russian Academy of Sciences.

${ }^{2}$ Material of Viservozhsky folklore field research (Scientific Archive of the Komi Scientific Centre: F.1. Op.11. D.244). Audio recordings are archived at the FF of ILLH (Kortkerossky collection).

3 The materials of folklore and dialectological field research collected in Kortkerossky District of the Komi Autonomous Soviet Socialist Republic (SA Komi SC: F.5. Op.2. D.233a). Sound recordings are archived at the FF of ILLH.

4 The material collected in 1994 is archived at the FA of SSU; materials from 1995 to 2000 are archived at the FF of ILLH (Kortkerossky collection).

5 Чивиль-чивиль is an onomatopoeic word which means the twitter of the sparrow.

${ }^{6}$ From this point on, in the names of the songs, the words and expressions that are untranslatable (misspelled) are put in italics.

7 Report by G.A. Muravyova and P.I. Chistalyov about a folklore field research in Storozhevsky District in the Komi Autonomous Soviet Socialist Republic (SA Komi SC: F.1 Op.11. D.244a. L. 260, 261).

8 Traditional pastry.

9 Recorded by G. Savelyeva in Syktyvkar in 1997, from the inhabitants of the village of Nivshera, E.M. Podorova, born in 1932, and A.S. Gabova, born in 1933 (FF of ILLH: V1108-8).

From this point on the texts are presented with word-for-word translation made by the author of the article. In some texts, there are individual lexical units in the Komi language in brackets.

${ }^{10}$ Recorded by Y. Rochev and V. Lyashev in the village of Nivshera in 1978 (SA Komi SC: F.5. Op. 2. D.233a, No. 100).

${ }^{11}$ From this point on, three dots in the text of the songs indicate the refrain.

${ }^{12}$ Recorded by G. Savelyeva in Syktyvkar in 1997, from the inhabitants of the village of Nivshera, E.M. Podorova, born in 1932, and A.S. Gabova, born in 1933 (FF of ILLH: V1108-9).

${ }^{13}$ Recorded by G. Savelyeva in Syktyvkar in 1997, from the inhabitants of the village of Nivshera, E.M. Podorova, born in 1932, and A.S. Gabova, born in 1933 (FF of ILLH: V1119-12).

${ }^{14}$ Recorded by A. Panyukov and G. Savelyeva in the village of Nivshera in 1999, from E.M. Podorova, born in 1932 (FF of ILLH: V1112). 
${ }^{15}$ Recorded by A. Panyukov and G. Savelyeva in the village of Nivshera in 2000, from A.S. Gabova, born in 1933, G.M. Larukova, born in 1922, E.M. Podorova, born in 1932, A.M. Zhizheva, born in 1928, and A.K. Larukova, born in 1929 (FF of ILLH: V1115-18, 20 ).

${ }^{16}$ Recorded by A. Panyukov and G. Savelyeva in the village of Nivshera in 1999, from A.S. Gabova, born in 1933, G.M. Larukova, born in 1922, E.M. Podorova, born in 1932 , A.M. Zhizheva, born in 1928, and N.V. Yeftene (Podorova), born in 1963 (FF of ILLH: V1112).

${ }^{17}$ The phenomenon of кьљдљs poч is dealt with in a number of articles by Anatoly Panyukov (e.g. Panykov 2003).

${ }^{18}$ Recorded by A. Panyukov and G. Savelyeva in the village of Nivshera in 2000, from A.S. Gabova, born in 1933, G.M. Larukova, born in 1922, E.M. Podorova, born in 1932, A.M. Zhizheva, born in 1928, and A.K. Larukova, born in 1929 (FF of ILLH: V1115-17).

19 The meaning of the expression потан улььн was provided by one of our informants, N.V. Yeftene (Podorova), born in 1963, and the handwritten text of the same song was also written down as told by her. The orthographic intricacies of the text in question allow to comment on the interpretative perception of this song.

${ }^{20}$ Recorded by G. Savelyeva in Syktyvkar in 1997, from the inhabitants of the village of Nivshera, E.M. Podorova, born in 1932, and A.S. Gabova, born in 1933 (FF of ILLH: V1108-7).

${ }^{21}$ Recorded by A. Panyukov and G. Savelyeva in the village of Nivshera in 2000, from A.K. Larukova, born in 1929 (FF of ILLH: V1115-21).

${ }^{22}$ Recorded from M.A. Popova, born in 1963, in the village of Nivshera (FDA).

${ }^{23}$ Recorded by A. Panyukov and G. Savelyeva in the village of Nivshera in 1999, from A.S. Gabova, born in 1933, G.M. Larukova, born in 1922, E.M. Podorova, born in 1932, and A.M. Zhizheva, born in 1928 (FF of ILLH: V1112).

${ }^{24}$ Aleksandra Stepanova Gabova, born in 1933, Glafira Matveevna Larukova, born in 1922, Ekaterina Matveevna Podorova, born in 1932, Aleksandra Matveevna Zhizheva, born in 1928, Anna Kirillovna Larukova, born in 1929, Nina Vassilyevna Yeftene (Podorova), born in 1963.

${ }^{25}$ Recorded by A. Panyukov and G. Savelyeva in the village of Alekseevka in Nivshera village soviet in 2000, from M.G. Gabova, born in 1932 (FF of ILLH: V1114-40).

${ }^{26}$ Recorded by A. Panyukov and G. Savelyeva in the village of Alekseevka in Nivshera village soviet in 2000, from M.G. Gabova, born in 1932 (FF of ILLH: V1114-40).

${ }^{27}$ Recorded by A. Panyukov and G. Savelyeva in the village of Nivshera in 2000, from Anisya Timofeevna Gabova, born in 1905 (FF of ILLH: V1116-57).

${ }^{28}$ Recorded by A. Panyukov and G. Savelyeva in the village of Nivshera in 2000, from A.T. Gabova, born in 1905, and L.I. Larukova, born in 1940 (FF of ILLH: V1116-61). 
${ }^{29}$ Recorded by A. Panyukov and G. Savelyeva in the village of Alekseevka in Nivshera village soviet in 2000, from M.G. Gabova, born in 1932 (FF of ILLH: V1114-40).

${ }^{30}$ Recorded by A. Panyukov and G. Savelyeva in the village of Nivshera in 2000, from A.T. Gabova, born in 1905 (FF of ILLH: V1116-57).

${ }^{31}$ Recorded by A. Panyukov and G. Savelyeva in the village of Alekseevka in Nivshera village soviet in 2000, from A.S. Gabova, born in 1925 (FF of ILLH: V1114-10).

${ }^{32}$ Recorded by A. Panyukov and G. Savelyeva in the village of Alekseevka in Nivshera village soviet in 2000, from M.G. Gabova, born in 1932 (FF of ILLH: V1114-40).

${ }^{33}$ Recorded by A. Panyukov and G. Savelyeva in the village of Alekseevka in Nivshera village soviet in 2000, from A.S. Gabova, born in 1925 (FF of ILLH: V1114-12).

${ }^{34}$ Recorded by A. Panyukov and G. Savelyeva in the village of Nivshera in 2000, from A.T. Gabova, born in 1905 (FF of ILLH: V1116-57).

${ }^{35}$ Recorded by A. Panyukov and G. Savelyeva in the village of Nivshera in 1999, from E.M. Podorova, born in 1932, and A.S. Gabova, born in 1933 (FF of ILLH: V1112).

\section{REFERENCES}

Bernshtam, Tatiana 1978. Devushka-nevesta i predbrachnaia obriadnost' v Pomor'e v XIX - nachale XX v. [The Bride and Ante-nuptial Rituals in Pomor'e in the 19th and early 20th Centuries.] In: K. Chistov \& T. Bernshtam (eds.) Russkii narodnyi svadebnyi obriad: Issledovaniia $i$ materialy. Leningrad: Nauka, pp. 48-71. Available at https://www.booksite.ru/fulltext/chistov/text.pdf, last accessed on 19 June 2019.

Bolonev \& Melnikov 1985 = Bolonev, Firs \& Mel'nikov, Mikhail (comps.) Khorovodnye $i$ igrovye pesni Sibiri. [Circle Dance and Game Songs of Siberia.] Novosibirsk: Nauka.

Kaneva, Tatiana 1998. Pesenno-igrovoi fol'klor Ust'-Tsilemskogo raiona Respubliki Komi. [Song and Game Folklore of the Ust-Tsilemsky District of the Komi Republic.] Dissertatsiia na soiskanie nauchnoi stepeni kandidata filologicheskikh nauk. Institute of Russian Literature, Russian Academy of Sciences. Available at https:// www.dissercat.com/content/pesenno-igrovoi-folklor-ust-tsilemskogo-raionarespubliki-komi, last accessed on 19 June 2019.

Krasnopolskaya, Tamara (comp.) 1977. Pesni Karel'skogo kraia. [Songs of the Karelian Region.] Petrozavodsk: Kareliia. Available at https://www.booksite.ru/fulltext/ dobrovol/text.pdf, last accessed on 19 June 2019.

Kuznetsov, Nikolai \& Lobanova, Liudmila 2014. Kollektsii komi fol'klora v estonskom fol'klornom arkhive. [Collections of Komi Folklore in the Estonian Folklore Archives.] In: Y. Krasheninnikova (chief ed.) Aktual'nye problemy sobiraniia i publikatsii fol'klornykh materialov. Sbornik nauchnykh trudov k 100-letiiu izdaniia knigi "Komi moidan kyv"ias". Syktyvkar: Institut iazyka, literatury i istorii Komi NTs UrO RAN, pp. 76-80. 
Lobanova, Liudmila \& Rassykhaev, Aleksei 2013. Narodnyi kalendar' v s. Bogorodsk Respubliki Komi. [Folk Calendar in the Village of Bogorodsk of the Komi Republic.] Zhivaia starina, No. 3, pp. 45-48.

Lobanova, Liudmila \& Rassykhaev, Aleksei 2016. Ustnye rasskazy o Tiuve: klassifikatsiia siuzhetov po zapisiam nachala XXI veka. [Oral Stories about Tyuve: Classification of Plots after the Records of the Early 21st Century.] Fol'kloristika Komi: issledovaniia $i$ materialy. Sator 17. Tartu: Nauchnoe izdatel'stvo ELM, pp. 185-222. https://doi.org/10.7592/Sator.2016.17.08.

Lobanova, Liudmila \& Rassykhaev, Aleksei 2017. Sovremennaia traditsiia pochitaniia pravoslavnykh ikon v s. Nivshera Kortkerosskogo r-na Respubliki Komi. [Contemporary Tradition of Veneration of Orthodox Icons in the Nivshera Village of Kortkerossky District of the Komi Republic.] Traditsionnaia kul'tura, No. 1, pp. 38-51.

Morozov, Igor 1998. Zhenit'ba dobra molodtsa: Proiskhozhdenie i tipologiia traditsionnykh molodezhnykh razvlechenii s simvolikoi "svad'by"/"zhenit'by". [Marriage of the Good Fellow: Origins and Typology of Traditional Youth Entertainment with the Symbolics of "Wedding"/ "Marriage".] Moscow: Labirint. Available at https:// www.academia.edu/2292246, last accessed on 19 June 2019.

Osipov, Ivan (comp.) 1941. Viser vozhsa s'ylankyv"ias da moidkyv"ias. [Songs and Fairy Tales of Vishera Vicinity.] Syktyvkar: Komi knizhnöi izdatel'stvo.

Osipov, Ivan (comp.) 1986. Viser vozhsa s'ylankyv"ias da moidkyv"ias. [Songs and Fairy Tales of Vishera Vicinity.] Syktyvkar: Komi knizhnöi izdatel'stvo.

Panyukov 2003 = Paniukov, Anatolii. Roch 'russkii' v komi traditsionnoi kartine mira. [Roch 'Russian' in the Komi Traditional World-View.] In: T. Ivanova (ed.) Lokal'nye traditsii v narodnoi kul'ture Russkogo Severa: Materialy IV mezhdunarodnoi nauchnoi konferentsii "Riabininskie chteniia-2003". Petrozavodsk: Muzeizapovednik "Kizhi", pp. 216-219. Available at https://kizhi.karelia.ru/library/ ryabinin-2003/55.html, last accessed on 19 June 2019.

Panyukov 2004 = Paniukov, Anatolii. Traditsii i sovremennost': Kharlampiev den'. (Kommentarii k videofil'mu). [Traditions and Contemporariness: Charalampus' Day (Comments to the Video).] Materialy Vtorogo Moskovskogo mezhdunarodnogo festivalia vizual'noi antropologii $i$ konferentsii "Traditsii i ob"ektiv: V poiskakh tsel'nosti". Moscow: TEIS, pp. 57-59. Available at http://visantmedia.mes.msu. ru/wp-content/uploads/2017/10/Materialy-II-MIFVA.pdf, last accessed on 19 June 2019.

Panyukov \& Savelyeva 2006 = Paniukov, Anatolii \& Savel'eva, Galina. Khramovye i zavetnye prazdniki v Komi krae (po polevym arkhivnym materialam). [Church and Sacramental Holidays in the Komi Region (on Field Archival Materials).] Paleoslavica, Vol. 14, pp. 262-286.

Savin, Viktor 1926. Musiur saiyn: Viservozhöd komi iözkostsa s'ylankyv"ias chukörtöm. [Behind the Watershed: Collecting Folk Songs across Vishera.] Komi mu, No. 9, pp. 33-41; No. 10 , pp. 35-38; No. 11, pp. 35-43.

Sorvachova \& Sakharova \& Gulyaev 1966 = Sorvacheva, Valentina \& Sakharova, Marfa \& Guliaev, Evgenii. Verkhnevychegodskii dialekt komi iazyka. [Upper-Vychegda Dialect of the Komi Language.] Syktyvkar: Komi knizhnoe izdatel'stvo. 
Teryukov 1983 = Teriukov, Aleksandr. Pogrebal'nyi obriad vymskikh i visherskikh komi. [Funeral Ceremony of the Komi of the Vym and the Vishera.] Traditsii i novatsii $v$ narodnoi kul'ture komi. Trudy IIaLI KFAN SSSR, Vyp. 28. Syktyvkar: Komi filial AN SSSR, pp. 25-31.

Zherebtsov, Liubomir \& Lashuk, Lev 1958. Staraia Vishera. [Old Vishera.] Istorikofilologicheskii sbornik, Vyp. 4. Syktyvkar: Komi knizhnoe izdatel'stvo, pp. 83-127. 


\title{
CHRISTMAS IN THE TRADITIONS OF RUSSIAN MINING SETTLEMENTS OF THE KOMI REPUBLIC (AS PER RECORDS OF THE EARLY TWENTY-FIRST CENTURY)
}

\section{Yulia Krasheninnikova}

Senior Research Fellow

Department of Folklore, Institute of Language, Literature, and History

Komi Science Centre, Russian Academy of Sciences, Russia

Email:krasheninnikova@rambler.ru

\section{Svetlana Nizovtseva}

Research Fellow

Department of Folklore, Institute of Language, Literature, and History

Komi Science Centre, Russian Academy of Sciences, Russia

Email: svetlananiz@mail.ru

\begin{abstract}
The article introduces folklore materials collected in the early twentyfirst century mostly from the Russian population of the mining settlements in the Komi Republic, which were founded when iron mining started in the area in the middle of the eighteenth century. The authors analyse the Christmas rituals and poetry used by children and adults when visiting neighbours at Christmas. The use of certain scenarios related to the celebration of Christmas and the Christmas period shows how the local traditions that developed among the varied population were integrated into the culture of Russian North and Central Russia.
\end{abstract}

Keywords: calendar complex, Christmas ritual, Christmas visitation, Komi Republic, praise, Russian folklore traditions

\section{CHRISTMAS CEREMONIALISM OF THE RUSSIAN LOCAL MINING TRADITIONS}

From 2008 to 2015, we collected texts about the celebration of Christmas and Christmas rituals from the population of three mining settlements. The texts help to understand the traditions of the first third to half of the twentieth century. We have analysed the collection of various sizes and informational capacities containing very specific information about the contents of the ritual 
activities; popular definitions, clarifying details of genres, peculiarities of performance, and contents of the ritual texts; gender, age, temporal, and territorial markers; explanation of the reasons for and consequences of performing a certain action or text from the point of view of the tradition-bearers.

House visitations to celebrate Christmas, dressing up, and divinations are the typical attributes of local traditional Christmas rituals. Correspondingly, we have divided the stories of Christmas rituals into three theme blocks. First, the stories of celebration - ritual house visitations by children and adults. The second theme, addressed by almost each and every interviewee, is dressing up. These texts cover costumed people's behaviour outside and inside the home, period of activity, costumes (list of elements and quality characteristics), masks, dressing-up characters, offering food to people wearing costumes. Less popular are topics related to making masks and psychological experiences of meeting the guisers or having been a Christmas guiser.

Lastly, we included many texts and listed witnesses concerning foretelling rituals - divinations for the name or appearance of a future husband or for the fortune (marriage, death, pregnancy, etc.) by using fence poles, flat cakes, footwear, the shadow of burnt paper, water frozen in the spoon, wedding rings, animals, etc., by listening at the cross-roads or at the window of the house, as well as narrations on the divinations which were fulfilled or did not come true, and actual stories of the interviewees' lives.

Although the materials are fragmented and varied, it is possible to find stable and optional elements in each theme block, showing the stability/optionality, regularity/irregularity, popularity/unpopularity, reproducibility/uniqueness of a verbal text, object, attribute, etc. in the tradition. Due to the vast amount of materials and the limited space of the article, we will cover in detail texts describing the visiting of homes during Christmas. Materials on Christmas celebrations in the Russian mining villages of the republic are fragmented and do not allow reconstructing a comprehensive picture of this phenomenon. At the same time, using research summarising the rituals in the Russian population of other regions and local traditions makes it possible to restore some aspects of Christ worship and provides some general and specific details of local rituals. 


\section{DETAILS OF CEREMONIAL ETIQUETTE}

We have collected materials about the secular praise of Christ, i.e., home visitation by the secular population. We did not collect any information about church or church-related visitations by priests, clergy, students of church schools, church choir, beggars (classification by Alexander Rozov; see Rozov 1999: 25). According to the interviewees, the Christ-worship visitations of homes by adults and children used to begin early in the morning on 7 January, i.e., on Christmas Day': 'When we were young, we used to go out to worship... It was still dark outside, but we ran to worship in the morning. ... Here we were, early in the morning on Christmas Day...'2

There is little or no evidence to any preparation, composition, gender, or age of the worship groups. The records mention both group and individual worship visitations, for example: 'It is Christmas worship, yes, Christmas. That I know, they came to me, I lived in this house already, they came to me. Kostikha, like, Kosarikha ${ }^{3}$, and... six people'. ${ }^{4}$ Judging by the number of records of the poetical texts and comments from the interviewees, the children's Christmas visitations were popular in all three mining villages, especially in Kazhym and Nyuchpas, but in the village of Nyuvchim the data about Christmas celebrations and 'singing divine songs' present sporadic, solitary examples. It is known that children more often went to worship at their relatives: 'We did not go much to strangers; we went to our relatives. Where the relatives are, there they run...'5; 'I also went to my grandmother and to my aunties, I went. ... I went to mine'6, etc.

There is no information about the use in Kazhym, Nyuchpas, or Nyuvchim of any special worship attributes (star, lantern, crèche, 'racheya'7, etc.) that were popular in the Northern Russian traditions.

At the entrance of the house, the worshippers got the host's permission to perform the worship ritual. The permission was granted in the form of implicit dialogue, always in the same form: 'Do you praise Christ?' - 'Praise!' Then the ritual started, followed by prayers and/or Christmas rhymes.

The hosts would greet the worshippers and give them pastry, eggs, candies, and small change, which the children would share:

Somebody would give us two roubles; if someone was baking cakes, then they would give us; we would come with a bag. And we were happy, as those were hungry times...8

They would give us a kopek, perhaps, or something similar, a candy, a cookie, or something baked...9 


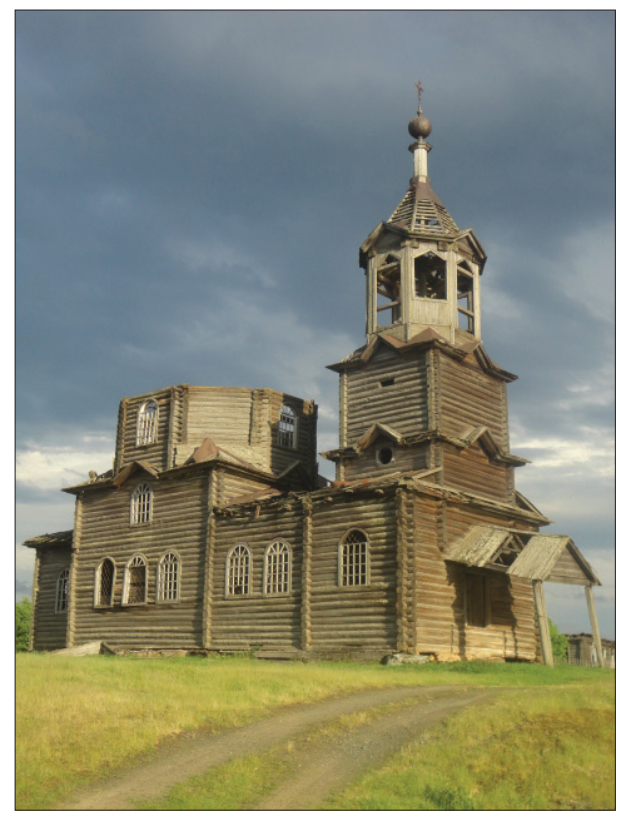

Figure 1. The Church of St. Prokopy of Ustyug in Nyuchpas, Koygorodsky District. Photograph by Yulia Krasheninnikova 2013.

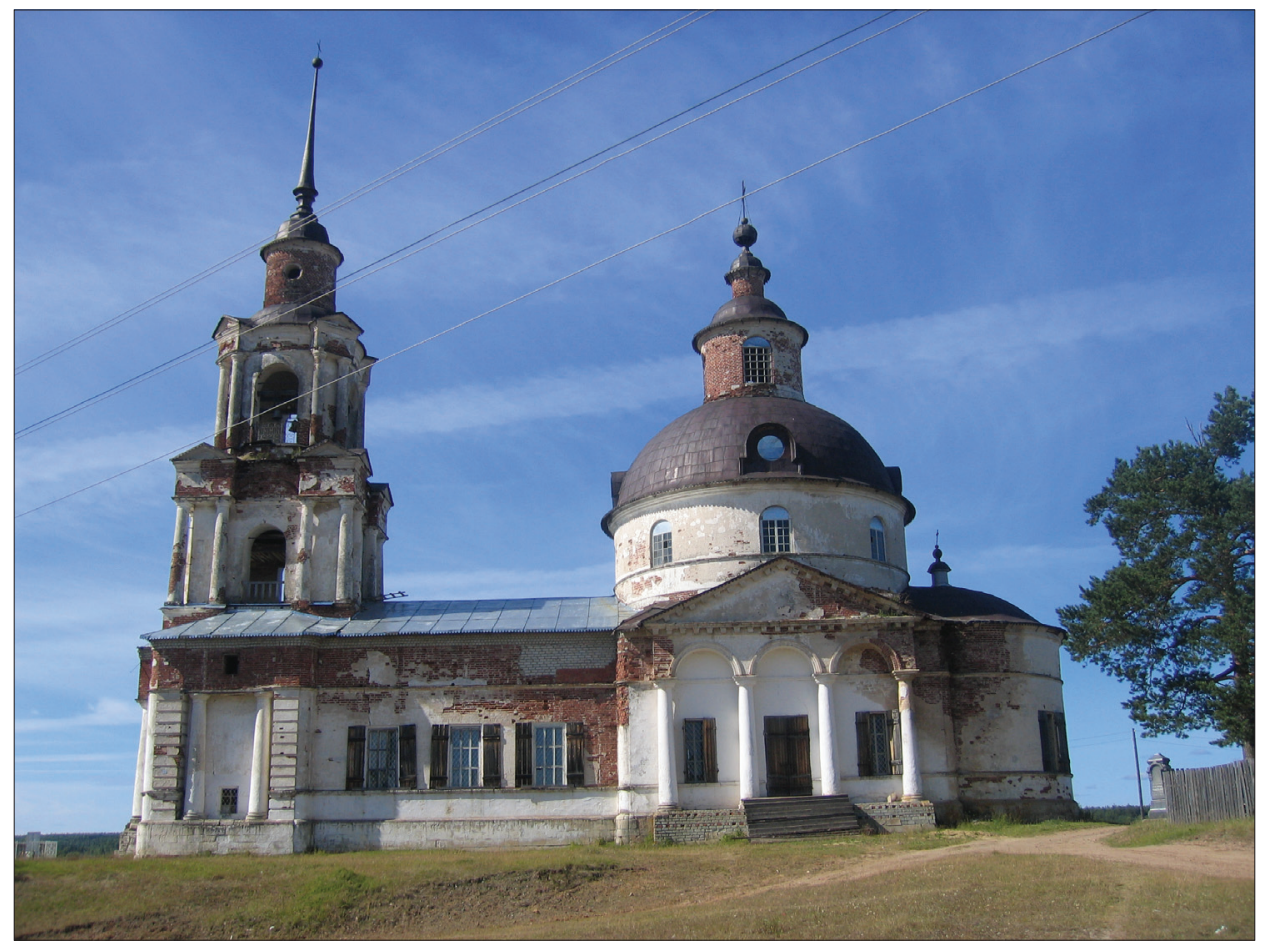

Figure 2. The Church of St. Dimitry of Rostov in Kazhym, Koygorodsky District. Photograph by Yulia Krasheninnikova 2010. 
Well, someone would give a cake, someone would give a bun, someone would give something else. But they seldom gave money. But they did. Someone would give small change, kopeks. And once we went with one woman, well, a girl, and they gave us five roubles. We were almost mad, we ran desperately to the shop to change the five roubles... ${ }^{10}$

It was generally assumed that paying to the worshippers would bring luck to the family, so the hosts tried to satisfy their request. Research shows that monetary gifts are directly tied to the veneration of ancestors and have a prognostic, producing, and protective function: 'The desire to pay the visitors well to ensure the wellness of the household and the family was supported by a rather archaic belief that the deceased ancestors can not only tell the future but also influence life in other ways' (Vinogradova 1982: 148).

Interviewees born in the 1940s spoke about the declining tradition of Christmas visitations. According to them, the tradition began fading away approximately at the end of the 1950s:

Юньчик, юньчик, прыг на стульчик, стульчик на бочок, дай пятачок [Little boy, little boy, jumps on a chair, the chair trips, give me a fiver.] It was [performed] by little children. And the adults ... would sing something like in the church, that was what they sang. They also took part in the visits, well, when I was young. And later, they stopped the worship, and children stopped visiting, but before, we used to go often. ${ }^{11}$

\section{THE LOCAL CHRISTMAS REPERTOIRE IN THE CONTEXT OF THE ALL-RUSSIAN TRADITION}

The repertoire of adult worshippers included the troparion 'Your Christmas Christ our Lord...' and the hirmos 'Christ is being born, praise...' Sometimes, these were also sung by children and teenagers, who had learned it from their parents. When interviewed, the interviewees tried to follow the traditional way of singing (singing and reciting), combining the fragments of various liturgical texts into one text or borrowing and combining fragments from various canonical texts, affording alterations of canonical texts in their oral manifestation (срящите - здравствуйте 'meet him - greet him', лирови свет разула лира и всех разула 'world with the light of knowledge - peace and reason to all', etc.; bold font shows the similarities of the texts): 
[Praiser's repertoire]

Here he starts praising:

Христос рождается славитЕ!

Христос в небе здравствуйте!

Христос на зеллевозноситеся!

Воспойте, люди, яко

прославился!

Christ is being born - praise him! Christ is in the sky - greet him! Christ is on the Earth - ascend! Sing people, as we are glorious!

Рождество Твое Христе

Боже нас,

Воссияя лира и всех разула.

Тебе кланяелся, света

божьего...

Christ, us Lord, Your Birth

Shining peace and reason to all.

We bow to you, divine light...

[Further] I forgot... ${ }^{12}$
[Canonical texts]

Canon 1. Hirmos

Христос рождается славите!

Христос с Небес-срящите.

Христос на зеллевозноситеся.

Пойте Господеви, вся зелля, И веселием воспойте,

людие,

Яко прославися...

Christ is being born - praise him! Christ from the sky - meet him! Christ is on the Earth - ascend. Sing the God, the whole earth And sing with joy, people

As $\mathrm{He}$ is glorious...

Troparion, mode 4

Рождество Твое Христе

Боже наш,

Возсия мирови свет разула, В нел бо звездал служашии

Звездою учахуся

Тебе кланятися, Солниу

Правды,

И Тебе ведети с высоты

востока.

Господи, слава Тебе.

Christ, our Lord, Your Birth

Enlightened the world with the light of knowledge

Because through Him those who served the stars

We taught by the star

To bow to you, Sun of the Truth And know you, the sun rising to the high.

Lord, Glory to You. (Azbuka) ${ }^{13}$ 
The reasons for the fragmentation of the texts, the inconsistencies in the descriptions of the Christmas visitation process, and the lack of earlier evidence can be attributed in part to the age of the interviewee answering the questions (most of them were born in the 1930s), the fact that churches were closed in mining villages in that period, and that the Christmas rituals were disapproved. All of this prevents studying the phenomenon in more detail.

The texts and recollections about Christmas celebrations as presented by the interviewees who were children at the time, based on their personal experience and personal feelings, are collected more often. These records, in addition to the description of worship actions, include the time and age markers, motivation, examples of popular terminology, and various versions of poetical texts.

In these mining settlement traditions, children performed the Christmas rhymes унчик, the versions of which were recorded in many Russian traditions, in particular in Arkhangelsk, Vologda, Vyatka, Ulyanovsk, Nizhniy Novgorod, and Voronezh oblasts, Prikamye (Vlasov 1995: 156; Drannikova 2000: 46; Chernykh 2008: 101; Korepova 2009: 40; Voroshilin 2009: 31; Safronov 2011), etc. Alexander Rozov, referring to Yevgeny Kostiukhin, notes that this tradition originated from Polish schoolchildren; then, it was borrowed by Ukrainians and Belarusians, and was later adopted in Russia (Rozov 1999: 48). The researchers do not agree about the genre of the texts: in scientific terminology, they are referred to as 'glorifying rhymes' (Korepova 2009: 39-40), 'Christmas song', which were 'chanted or sang' (Rozov 1999: 48), Christmas carol (Vlasov 1995: 156), рацейка (Drannikova 2000: 46) ${ }^{14}$, славка 'glorifying chant' (Chernykh 2008: 97, 101), etc. Publishers and collectors in the nineteenth century called these texts children's ratseya (P.A. Bessonov, G.K. Zavoiko, A. Sheshenin), припевка 'ditty', присказка 'saying' (G.S. Vinogradov, A.N. Sobolev) (Rozov 1999: 48).

Local popular terminology offers terms like присказулька 'short tale', припевка 'ditty', стишок 'short poem'. ${ }^{15}$ Commenting the peculiarities of performing these texts, the interviewees say that they are sang and spoken aloud or refer to the singing-recitative manner: 'Words, words they say as the song goes. They sing it a bit, just like a song. ${ }^{16}$ By these definitions, the interviewees refer to the brevity and laconism of the form, often light, casual, funny content, and peculiarities of performance; and refer to the ideas developed within the tradition of the children's genre as non-serious, in a simple form, and not meaningful. ${ }^{17}$

Modern examples show degrees of textual variability: from 2 to 4 lines to longer versions, where at the beginning, a character of a boy (вьюньчик /юньчик) is introduced, then the main part describes his actions ('sat on a chair', 'jumped/ jumps on the chair', 'plays reedpipe', 'gathers guests', 'congratulates Christ', 'glorifies Christ'), and the conclusion includes a request for a gift ('give me a rouble/fiver', 'open your chest, give me a fiver', etc.) and something tasty ('to the children for ginger bread'): 
Маленький юньчик,

Сел на стульчик,

Дудочкой играет,

Христа поздравляет.

Со скотол, животол,

С пшеницею, с овсол.

Тьь, хозяин-лужичок,

Полезай в сундучок,

Доставай пятачок.

Нал на орешки,

Деткал на потешки.
Little iun'chik [little boy],

Sits on a chair,

Plays the reedpipe,

\section{Congratulates Christ.}

With cattle, with belly,

With wheat, with oats.

You, the host man,

Go to your chest,

Get a fiver.

For us to buy nuts,

For the children to have fun. ${ }^{18}$

Shorter versions have been recorded, where the idea of glorifying the birth of Christ or Christ and those present was the central motif:

Юньчик, юньчик,

Сел на стульчик

В трубочку играет

Христа поздравляет.
Iun'chik, iun'chik [little boy, little boy], Sits on a chair, Plays the pipe

Congratulates Christ. ${ }^{19}$

Or:

Вьюньчик, вьюньчик,

Сел на стульчик.

Дедушку и бабушку,

И Христа поздравляет.
Viun'chik, v’iun'chik [Littleboy, littleboy], Sits on a chair,

Grandfather and grandmother and Christ he congratulates. ${ }^{20}$

Some poetical versions show the 'loss of the main part of Christmas rituals glorification of Christ' (Rozov 1999: 48) and present the idea of request for money or something tasty:

Юньчик, юньчик,

Скок на стульчик.

Стульчик на бочок,

Дайте пятачок.

Or:

Маленький юньчик,

Прыгнул на стульчик.

Я пришел не так -

Дайте денюжку пятак!
Iun'chik, iun'chik [little boy, little boy], Jumped on a chair, The chair tripped

Give me a fiver. ${ }^{21}$
Little iun'chik [little boy], Jumped on a chair, I have come not for nothing Give me some money, a fiver! ${ }^{22}$ 
A. Rozov notes that some versions of the text were collected in the 1970s1990s 'both from elderly singers recollecting their childhood, and from boys and girls, and highlights that the main goal of these poems was 'to make fun, entertain the audience', whereas performing 'unchik' by children and adults in the 1920s-1940s 'definitely illustrates the decline of the Christ glorification tradition' (Rozov 1999: 48). Data from the first decade of the twenty-first century supports these conclusions. Persons who witnessed performing $у н ц и к$ in the 1930s-1940s and the motivations of interviewees suggest that the aesthetical function of the texts was less important than the practical function (receiving food or things), as explained by the interviewees, or rather, by the difficult situation of the local people:

... and they would compliment you, give something to you, a candy if they have. Maybe only some sugar, as there was nothing tasty to give. Or a cake, perhaps... ${ }^{23}$

Whatever they had, who gave candies, who gave cookies, who would give some money, some kopeks, they gave whatever they could. ${ }^{24}$

So, some would give money - kopeks, some would give a pastry, some would give candies... And we would perform, and then will buy with this money a jacket, some fabric for a jacket, a skirt, or a dress; we had nothing, we lived poor. ${ }^{25}$

Secondly, the interviewees clearly distinguish 'worship' genres from adult and children's repertoire. Individual witnesses said that children could also 'praise with prayer'. This type of worship was possible if adults had taught children to pray, and therefore, the main criteria for the performance were whether you were taught or not taught, whether you can or cannot pray. However, the comments consistently illustrate that prayers are performed by the adults, while унчик is for children:

They, little ones, sang it [унчик - Y.K., S.N.], while the adults - they would sing 'Christ is being born - praise him!'26

- They say that people in old times would visit and praise Christmas?

- Those who knew, old people....

- Did children praise, too?

- Children - no, they only listened.

- Did they not sing 'Little iunchik?

-Oh, iun'chik, yes, they sang, sang... ${ }^{27}$

...children said [унчик - Y.K., S.N.]. And the adults had a proper prayer. ${ }^{28}$ 
Commenting the age distribution of 'worship' genres, the interviewees implicitly highlighted the 'value' of ritual texts, their importance, and significance for the ritual: adults had a 'proper prayer'29, while children spoke 'simple words'.

Thirdly, the interviewees attempt to separate the local (old-timer) and 'imported' (in particular, by the new settlers and seasonal workers) repertoires, paying attention to the time markers and place of origin of a text. An interviewee, commenting on one of the унчик examples, marks terminological differences in describing the Christmas home visitation process: славить Рождество (glorify Christmas) (variant: ходить славить (go to glorify) - is a local term, while колядовать (sing carols) is a Ukrainian tradition term:

- ...went to the neighbours and koliadovali the Ukrainian way.

- Did you call it so?

- No. It is in Ukrainian 'koliadovali'.

- And how did you call it?

- Worship... ${ }^{30}$

In another example from the same village, an interviewee explains singing koliada ${ }^{31}$ :

- Koliada is there, in the south [territories], we did not sing koliada.

- Where is 'there'?

- For example, I lived in Belarus, so there they went koliadovat'. But here they did not koliadovali, they slavili. And there were koliadki. ${ }^{32}$

Some comments characterise the contents of local children's Christmas songs. The interviewee quotes a part of a children's decrying song sung at Christmas, which was performed in the event of poor wages, and says that it was sung in Belarus, while in Kazhym, children sing 'all kinds of Christmas songs'. By this implicit opposition (smutty vs. decent, appropriate), the content of local children's songs is characterised as positive or neutral:

- Our children would sing this smutty song:

'And in this hut

Nothing to give,

The furnace is shabby,

The housewife [name] is dirty, messy'.

Then, they would run out with sticks and chase away.

- Did they sing this in your neighbourhood in Belarus?

- Yes, this was sung there. And here, children sing all kinds of Christmas songs... ${ }^{33}$

The evidence proves that the tradition of коляда (Christmas visitations with carols) might have existed in the mining villages. The interviewees mention 
коляда as part of the local tradition, using the term коляда and defining the actions of worshippers with the verb колядовать. For example, the following is a fragment of an interview with an interviewee from Kirov Oblast, who moved to the village of Kazhym in 1955:

- And during Christmas, there are koliadki, yes there are.

- Is it what you called it here, koliadki?

- For example, in my house, the grannies, yes, would come, and I lived with my mother-in-law, and say: 'May we koliadovat'?'

- Was it in Kirov Oblast?

- No, it was here, [when] I lived with my mother-in-law. They came to koliadovat'. Sang: 'Коляда mьı, коляда, // Tьь да выйди за ворота... [Koliada, you koliada, // You get out of the gate...' Then something like '...Не дашь пирожка, // Mь, говорит, теленка за рога... [...If you do not give us cake, // We, say, take your calf by the horns...] And then would start something, some пискатульки ${ }^{34}$. Yeah, well, then we give them something. Children would also come... ${ }^{35}$

The interviewee cites two fragments of the коляда, where the first fragment is also part of the worship visitation and depicts the coming of worshippers (i.e., it is the introductory part). The second fragment is a threatening request for alms or food. Vladimir Chicherov analyses in detail this type of New Year wish songs, which include a request for ritual alms. He notes that the songs of this type are seldom individual but 'are almost always parts from another text' (Chicherov 1957: 124). In the songs, the request for alms 'is in the form of a threat to cause damage to the house unless the request is satisfied' (ibid.), 'it is a demand that becomes a threat to bring trouble' (Chicherov 1957: 126). ${ }^{36}$

In another fragment of a коляда collected in the Nyuchpas village, we see an allusion to the Яблочко (Apple) song that was popular in the city environment: ${ }^{37}$

- They would come with koliada. They would bring something, somewhat... 'Коляда ты, коляда, куда катишься? // Ко лне в рот попадешь, не воротишься...' [Koliada you, koliada, where are you rolling? // You will get into my mouth and will not come back...] That was what they sang. They would come with koliada, I lived in this house already....

- Did they come with koliada here?

- Yes, yes.

- So they would celebrate Christmas on the seventh of January?

- Yes.

- Do they sing a Christmas prayer? 
- Yes. [The next day] koliada: 'Коляда, ты коляда, куда катишься? // Ко лие в рот ведь попадешь, не воротишься...' [Koliada you, koliada, where are you rolling? // You will get into my mouth and will not come back...] That was what they said. They would come with this. Well, they sing some prayers, not what I tell you.

- Did they come with koliada on the second day?

- Yes, on the second day, they would come with koliada. [And on the third day] girls would dress-up and come. ${ }^{38}$

\section{CONCLUSION}

Though the data are fragmented and mosaic, we can say that the Christmas ritual as part of the popular calendar of the Russian population in the Komi Republic mining villages was rather dense, and similar to the other Russian local traditions in respect of symbolic actions, modes of behaviour, types of magic practices, and samples of verbal folklore. The use of certain scenarios, related to Christmas celebrations and the Christmas period, shows how the local traditions, formed by the ethnically varied population (see Krasheninnikova 2019), 'build in' the culture of the Russian North and Central Russia, and some relics of the mother cultures have become integral parts of the local traditions in the course of development of the latter. The analysis of the Christmas rituals and poetry in the records of the early twenty-first century shows similarities of the contents of the ritual activities (house visitations in order to glorify Christmas), modes of behaviour, types of magic practices (dressing-up), and verbal folklore with other local Russian traditions. The modern records also show the decline of the glorifying Christmas tradition, which is manifested in the lack of clear information about the age, gender, and number of worshippers, absence of the praising attributes (star, lantern, crèche, etc.), visitations mostly of the relatives by children, and reduction of the poetic repertoire.

\section{NOTES}

1 The Catholic Church and the Protestant streams of Christianity celebrate Christmas Day on 25 December according to the modern Gregorian calendar. The Orthodox Church celebrates Christmas Day on 25 December according to the Julian calendar (or 'old style'), which corresponds to 7 January of the modern Gregorian calendar (see https://ria.ru/20071224/93923436.html, last accessed on 23 July 2019).

${ }^{2}$ Recorded by Y. Krasheninnikova in Nyuchpas, on 19.06.2013, from P.N. Kozlova, born in 1942.

3 Local female nicknames; the wives were called by the family names of their husbands; therefore, Kosarikha's husband was Kosarev, and Kostikha's husband - probably Kostin. 
4 Recorded by Y. Krasheninnikova in Nyuchpas, on 18.06.2013, from N.N. Chesnokova, born in 1933, and G.N. Mikhailova, born in 1928.

5 Recorded by Y. Krasheninnikova in Nyuchpas, on 18.06.2013, from L.N. Kushkhova, born in 1931, O.N. Obrezanova, born in 1937, and E.N. Karmanova, born in 1944.

${ }^{6}$ Recorded by Y. Krasheninnikova in Kazhym on 2.07.2010, from L.V.Vavilova, born in 1930.

7 Aleksandr Rozov, with reference to data by S. Dmitrieva (Dmitrieva 1988: 19), mentions рачея 'a rack decorated with multicolored pieces of paper' as a local attribute of Christmas Glorification of Christ in Mezensky and Kholmogorsky districts of Arkhangelsk Province (Rozov 1999: 40).

8 Recorded by S. Nizovtseva and P. Shakhmatskaya in Kazhym, on 24.06.2013, from N.V. Guryeva, born in 1938.

9 Recorded by S. Nizovtseva and P. Shakhmatskaya in Nyuchpas, on 18.06.2013, from E.N. Kosareva, born in 1948.

${ }^{10}$ Recorded by Y. Krasheninnikova in Kazhym, on 25.06.2013, from I.N. Kuzmina, born in 1927, and N.K. Zadorozhnaya, born in 1955.

${ }^{11}$ Recorded by S. Nizovtseva and P. Shakhmatskaya in Nyuchpas, on 19.06.2013, from M.N. Volodicheva, born in 1948.

12 Recorded by L. Lobanova, S. Nizovtseva, and A. Rassykhaev in Nyuchpas, on 5.06.2011, from D.I. Kostin, born in 1935.

${ }^{13}$ A. Rozov says that in the nineteenth century, in the course of glorification by the clergy, they performed two pieces of the big Christmas repertoire that they usually perform in the church - the troparion 'Your Birth, Christ our God', and the kondak 'Today Virgin Gives Birth to Ever-Existing' (Rozov 1999: 27), as well as secular praisers - the troparion 'Your Birth, Christ out God', the kondak 'Today Virgin', the hirmos 'Christ is Being Born', and stichera, adding congratulations to the host on the holiday or wishes of long life (Rozov 1999: 41).

${ }^{14}$ See also G. Vinogradov's term 'ratseika transformed into counting rhyme' (Vinogradov 1998: 356, No. 406 a, b, v).

15 The meanings of these words include the following: присказулька - diminutive from the noun присказка 'short funny story, a joke' (Ushakov 1939: vol. 3, col. 848); присказка - fig. col. 'storyteller's introduction' (Efremova 2000); Vologda, Perm 'joke, saying'; Vyatka 'ditty' (SRNG 1997: 383); припевка - Vyatka, South-Siberian 'ditty'; Vologda, Perm. In the wedding ritual a praising short song, often remunerated with gifts, money, etc. (SRNG 1997: 338).

${ }^{16}$ Recorded by Y. Krasheninnikova in Kazhym, on 3.07.2010, from T.S. Filyova, born in 1934, origin. from Brest Oblast, Belarus.

${ }^{17}$ About the use of popular terminology to describe the genre and its characteristics, see Krasheninnikova 2011.

${ }^{18}$ Recorded by Y. Krasheninnikova in Kazhym, on 3.07.2010, from V.N. Filyov, born in 1934, and T.S. Filyova, born in 1934, origin. from Brest Oblast, Belarus.

${ }^{19}$ Recorded by Y. Krasheninnikova in Kazhym, on 24.06.2013, from D.N. Shishnev, born in 1932. 
${ }^{20}$ Recorded by Y. Krasheninnikova and S. Nizovtseva in Kazhym, on 26.06.2013, from G.A. Karavaeva, born in 1939.

${ }^{21}$ Recorded by Y. Krasheninnikova in Nyuchpas, on 19.06.2013, from P.N. Kozlova, born in 1942, origin. from Nyuchpas village.

${ }^{22}$ Recorded by A. Rassykhaev, L. Lobanova, and S. Nizovtseva in Nyuchpas, on 5.06.2011, from D.I. Kostin, born in 1935, and A.N. Kostina, born in 1934, origin. from Vygonichskiy Region of Bryansk Oblast; moved to Nyuchpas in 1958.

${ }^{23}$ Recorded by Y. Krasheninnikova in Kazhym, on 2.07.2010, from L.V. Vavilova, born in 1930.

${ }^{24}$ Recorded by Y. Krasheninnikova in Kazhym, on 3.07.2010, from V.N. Filyov, born in 1934, and T.S. Filyova, born in 1934, origin. from Brest Oblast, Belarus.

${ }^{25}$ Recorded by Y. Krasheninnikova in Nyuchpas, on 19.06.2013, from P.N. Kozlova, born in 1942.

${ }^{26}$ Recorded by Y. Krasheninnikova in Kazhym, on 25.06.2013, from I.N. Kuzmina, born in 1927.

${ }^{27}$ Recorded by Y. Krasheninnikova in Kazhym, on 25.06.2013, from V.D. Makarova, born in 1925 .

${ }^{28}$ Recorded by Y. Krasheninnikova and S. Nizovtseva in Kazhym, on 26.06.2013, from V.A. Karavaeva, born in 1939.

${ }^{29}$ In this respect, the local popular definition of the word молитва 'prayer' coincides with the connotations that it has in the culture. Most dictionaries are unanimous about the meaning of the word лолитва - 'canonical verbal text that believers pronounce when addressing the god' (Ushakov 1938: 247; see also Ozhegov 1987 [1949]: 307-308); 'praising, thankful or pleading address to God or saints; prescribed text, to be read or pronounced by a believer when addressing God or saints' (Efremova 2000); 'plead, petition; ... word, addressed to God' (SRIa 1982: 243-244).

${ }^{30}$ Recorded by S. Nizovtseva and P. Shakhmatskaya in Kazhym, on 22.06.2013, from I.M. Dobrova, born in 1934.

${ }^{31}$ We would like to also mention that this genre was popular in the Russian North, in particular in Vologda and Arkhangelsk provinces, and the texts of koliadka were performed both by adults and children (Rozov 1999: 42, 51).

${ }^{32}$ Recorded by Y. Krasheninnikova and S. Nizovtseva in Kazhym, on 26.06.2013, from G.A. Karavaeva, born in 1939.

${ }^{33}$ Recorded by Y. Krasheninnikova in Kazhym, on 3.07.2010, from T.S. Filyova, born in 1934, origin. from Brest Oblast, Belarus.

${ }^{34}$ According to the audio record; it should be read as присказульки.

${ }^{35}$ Recorded by Y. Krasheninnikova, S. Nizovtseva, and P. Shakhmatskaya in Kazhym, on 23.06.2013, from A.A. Burylova, born in 1933, origin. from Bol'shoi Kashnur village in Sovetskiy Region, Kirov Oblast.

${ }^{36}$ See Chicherov 1957: 123-130 about these texts and peculiarities of contaminations. 
${ }^{37} \mathrm{~S}$. Neklyudov in his analysis of the genres of contemporary city folklore mentions Яблочко (Apple) - a song of the late 1940s: 'Яблочко ( Эх, яблочко), куда ( куды) котишься? (sic!) / Ко мне в рот попадешь - не воротишься!' [Apple, where are you rolling? / You will get into my mouth and won't come back!]' The text ... was never perceived as unfinished and did not need any continuation' (Neklyudov 2011: 20). S. Neklyudov does not exclude that 'You will get into my mouth' is a reframing of the original 'You will get to Rostov' and explains that 'from a child's point of view it is much more natural for an apple to get into somebody's mouth than to an unknown Rostov' (Neklyudov 2011: 22).

${ }^{38}$ Recorded by Y. Krasheninnikova in Nyuchpas, on 18.06.2013, from N.N. Chesnokova, born in 1933, and G.N. Mikhailova, born in 1928.

\section{REFERENCES}

Azbuka = Pravoslavnoe bogosluzhenie. [Russian Orthodox Liturgy.] Available at https:// azbyka.ru/bogosluzhenie/kanonnik/kanon04.shtml, last accessed on 27 June 2019.

Chernykh, Aleksandr 2008. Rozhdestvenskie i novogodnie obkhody v russkikh traditsiiakh Permskogo Prikam'ia v kontse XIX - pervoi polovine XX veka. [Christmas and New Year Visitations in the Russian Traditions of Perm Kama Region in the Late 19th - First Half of the 20th Centuries.] Vestnik Udmurtskogo Universiteta. Seriia Istoriia i filologiia. [Bulletin of Udmurt University. Series of History and Philology.] No. 1, pp. 89-108. Available at http://ru.history.vestnik.udsu.ru/files/ originsl_articles/vuu_08_051_10.pdf, last accessed on 27 June 2019.

Chicherov, Vladimir 1957. Zimnii period russkogo narodnogo zemledel'cheskogo kalendaria XVI-XIX vekov: ocherki po istorii narodnykh verovanii. [Winter Period of the Russian Agricultural Calendar in the 16th-19th Centuries: Essays on the History of Folk Beliefs.] Moscow: Izd-vo Akademii nauk SSSR. Available at http://biblio.imli.ru/images/abook/folklor/CHicherov_V.I._Zimnij_period_ russkogo_narodnogo_zemledelcheskogo_kalendarya_XVI_-_XIX_vekov._1957. pdf, last accessed on 27 June 2019.

Dmitrieva, Svetlana 1988. Fol'klor i narodnoie iskusstvo Russkikh Evropeiskogo Severa. [Folklore and Folk Art of Russians of the European North.] Moscow: Nauka. Available at https://www.booksite.ru/fulltext/dmitrieva/text.pdf, last accessed on 23 July 2019.

Drannikova, Natalia 2000. Materialy k Pinezhskomu etnodialektnomu slovariu. [Materials for Pinega Ethic and Dialect Dictionary.] Zhivaia starina, No. 1, pp. 45-47. Available at https://inslav.ru/sites/default/files/zhs-2000-1.pdf, last accessed on 27 June 2019.

Efremova, Tatiana 2000. Novyi slovar' russkogo iazyka. Tolkovo-slovoobrazovatel'nyi. [New Dictionary of the Russian Language: Explanatory and Word-Forming.] Moscow: Russkii iazyk. Available at http://www.efremova.info, last accessed on 27 June 2019. Korepova, Klara 2009. Russkie kalendarnye obriady i prazdniki Nizhegorodskogo Povolzh'ia. [Russian Calendar Rituals and Holidays of the Nizhny Novgorod Volga Region.] St. Petersburg: Tropa Troianova.

Krasheninnikova, Yulia 2011. Russkie svadebnye prigovory v svete narodnoi terminologii. [Russian Wedding Chants in the Light of Folk Terminology.] Traditsionnaia kul'tura, No. 3, pp. 70-80. Available at http://www.trad-culture.ru/article/russkiesvadebnye-prigovory-v-svete-narodnoy-terminologii, last accessed on 27 June 2019. 
Krasheninnikova, Yulia 2019. Historical Folklore Prose of the Russian Metallurgical Traditions of the Komi Republic. Folklore: Electronic Journal of Folklore, Vol. 76, pp. 135-154. https://doi.org/10.7592/FEJF2019.76.krasheninnikova.

Neklyudov 2011 = Nekliudov, Sergei. Gorodskaia pesnia: pamiat' detstva. [City Song: Memory of Childhood.] Zhivaia starina, No. 1, pp. 19-22. Available at https:// inslav.ru/sites/default/files/zhs-2011-1.pdf, last accessed on 27 June 2019.

Ozhegov, Sergei 1987 [1949]. Tolkovyi slovar' russkogo iazyka. [Explanatory Dictionary of the Russian Language.] Izdanie 18, stereotipnoe. Moscow: Russkii iazyk.

Rozov, Aleksandr 1999. Russkoe rozhdestvenskoe khristoslavlenie (materialy i issledovanie). [Russian Christmas Glorification of Christ (Materials and Study).] In: A. Rozov (ed.) Russkii fol'klor: materialy i issledovaniia. [Russian Folklore: Materials and Studies]. Vol. 30. St. Petersburg: Nauka, pp. 20-53. Available at http://lib2.pushkinskijdom.ru/Media/Default/PDF/RusFolk/RusFolklore\%20 vol.30\%201999.pdf, last accessed on 27 June 2019.

Safronov, Evgeny 2011. Osobennosti ul'ianovskikh Sviatok. [Peculiarities of Ulyanovsk Christmas.] Ulpressa, 6 January. Available at https://ulpressa.ru/2011/01/06/ article143757/, last accessed on 21 June 2019.

SRIa 1982 = Slovar' russkogo iazyka XI-XVII vv. [Dictionary of the Russian Language of the 11th-17th Centuries.] Vyp. 9. Chief ed. F. Filin. Moscow: Nauka.

SRNG 1997 = Slovar' russkikh narodnykh govorov. [Dictionary of Russian Popular Dialects.] Chief ed. F. Sorokoletov. Vyp. 31. St. Petersburg: Nauka. Available at https://iling.spb.ru/dictionaries/srng/31.pdf, last accessed on June 27, 2019.

Ushakov, Dmitriy (ed.) 1938. Tolkovyi slovar' russkogo iazyka. [Explanatory Dictionary of the Russian Language.] Vol. 2. Moscow: Gosudarstvennoe izdatel'stvo inostrannykh i natsional'nykh slovarei.

Ushakov, Dmitriy (ed.) 1939. Tolkovyi slovar' russkogo iazyka. [Explanatory Dictionary of the Russian Language.] Vol. 3. Moscow: Gosudarstvennoe izdatel'stvo inostrannykh i natsional'nykh slovarei.

Vinogradov, Georgiy 1998. "Strana detei": Izbrannye trudy po etnografii detstva. [Country of Children: Selected Works on Childhood Ethnography.] St. Petersburg: Istoricheskoe nasledie.

Vinogradova, Liudmila 1982. Zimniaia kalendarnaia poeziia zapadnykh $i$ vostochnykh slavian. Genezis i tipologiia koliadovaniia. [Winter Calendar Poetry of Western and Eastern Slavs: Genesis and Typology of Christmas Visitations.] Moscow: Nauka. Available at https://inslav.ru/publication/vinogradova-l-n-zimnyayakalendarnaya-poeziya-zapadnyh-i-vostochnyh-slavyan-genezis-i, last accessed on 27 June 2019.

Vlasov, Andrey (ed.) 1995. Traditsionnyi fol'klor Vilegodskogo raiona Arkhangel'skoi oblasti (v zapisiakh 1986-1991 gg.): Issledovaniia $i$ materialy. [Traditional Folklore of Vilegodsk District (in the Records of 1986-1991). Research and Materials.] Syktyvkar: Syktyvkarskii gosudarstvennyi universitet. Available at https://territory.syktsu.ru/etnokulturnoe-nasledie/biblioteka/13.pdf, last accessed on 12 July 2019.

Voroshilin, Viacheslav 2009. Pesni novogodnikh i rozhdestvenskikh obkhodov v Voronezhskoi oblasti. [Songs of New Year and Christmas Visitations in Voronezh Oblast.] Zhivaia starina, No. 4, pp. 30-34. Available at https://inslav.ru/sites/ default/files/zhs-2009-4.pdf, last accessed on 27 June 2019. 


\title{
HISTORICAL FOLKLORE PROSE OF THE RUSSIAN METALLURGICAL TRADITIONS OF THE KOMI REPUBLIC
}

\author{
Yulia Krasheninnikova \\ Senior Research Fellow \\ Department of Folklore, Institute of Language, Literature, and History \\ Komi Science Centre, Russian Academy of Sciences, Russia \\ Email: krasheninnikova@rambler.ru
}

\begin{abstract}
The article introduces folklore materials collected in the twenty-first century from the Russian population of the mining villages in the Komi Republic, founded when iron mining started in the area in the middle of the eighteenth century. The folklore traditions originated from the Russian settlers coming from the northern, north-eastern, and central provinces of the European part of the Russian Empire. The author studies the stories of oral historical prose, reflecting the values of the settlers, events in the course of settling and reclaiming the territory, the beginning and development of pig iron and iron production, local dynasties, and information about actual historical prototypes. She also considers the procedure of forming a folklore repertory in a certain local tradition. By using historical sources and mass media publications and comparing them to folklore materials, the author concludes that in the twentieth century, the collective historical memory was 'designed', among others, by resources, the mass media, and book culture, and that local intellectuals were directly involved in the process.
\end{abstract}

Keywords: formation of the folklore repertoire, Komi Republic, oral historical prose, Russian folklore traditions

\section{SEVERAL FEATURES OF THE FORMATION AND STUDYING OF LOCAL TRADITIONS}

This work is dedicated to the Russian folklore traditions of the Nyuvchim (Syktyvdinsky District), Kazhym, and Nyuchpas (Koygorodsky District) factory settlements, the emergence of which on the territory of the Komi Republic was related to the opening of the iron-ore businesses in 1756-1761. The initiative of the building of the Kazhym, Nyuchpas, and Nyuvchim private metallurgical plants at the Sysola River and its tributaries is attributed to the merchants Andrey Panov, Andrey Plotnikov (Nyuvchim plant), Ivan Kurochkin, 
and Aleksandr Yurinsky (Kazhym and Nyuchpas plants), who, after having discovered deposits of bog iron ore at the Sysola River and researched the raw-material base, turned to the Collegium of Mining, which managed the development of the factory sector in Russia at the time, with a request to allow them to build the plants. In 1761, the plant in Nyuvchim was commissioned, and the plants in Kazhym and Nyuchpas started their operation in 1758 and 1757 respectively (Politov 2005: 91-93). ${ }^{1}$

Initially the main population (its qualified part) within the industry was made up by state peasants from the Vyatka and Veliky Ustiug provinces, who had been trained to work at the plant; fugitive peasants, who were hiding from compulsory military service and were paying duties were also hired (Politov 2005: 109, 111). The facts of state peasants from Slobodskoy and Yaransky uyezds of Vyatka Governorate, from the village of Seregovo (Zherebtsov 1962: 126), the recruitment at the beginning of the twentieth century of the labour force from Moscow, the Urals, and other governorates were recorded (Surina 1973: 69). From the archival documents of the turn of the nineteenth century, in particular, we learn about the intention of the owner of the Nyuvchim plant, Arkhip Gribanov, to buy 118 peasants (65 males and 53 females) from Vetluzhsky Uyezd of Kostroma Governorate and 118 peasants (56 males and 62 females) from Kadnikovsky Uyezd of Vologda Governorate (Politov 2005: 112).

As a matter of fact, the reference point of the formation of folklore traditions of the settlements of Nyuvchim, Kazhym, and Nyuchpas can be regarded to be the middle of the eighteenth century, after the plants were commissioned. In connection with the predominance of the population coming from the northern Russian and central governorates of the European part of Russia, a folklore culture based on the traditions of the places the plant workers were coming from was formed. ${ }^{2}$ The distinctive character of settlements (plant settlements with the 'town-forming' company), the functioning of the plants until the middle (the village of Kazhym) and the end of the twentieth century (the village of Nyuvchim), the inhomogeneous structure of the Russian population, and close contacts with the local Komi and settlers banished from different places in Russia - all of these factors as well as many others exerted their influence on the formation of the local folklore culture and, to a certain extent, determined the structure of folklore traditions.

In the process of its formation and development, migratory culture was experiencing non-unilinear and ununiform exposure. Firstly, the interaction of the Russian migratory and the indigenous Komi cultures should be mentioned. Secondly, 'folklore interrelations' inside the new settlers' traditions, apparently, were unequal too, since traditions were formed by the Russian population from different areas of Russia, and, correspondingly, the migrants were introducing 
their own perceptions of the lifestyle and spiritual culture into the local tradition. However, the preservation and predominance of one or another cultural phenomenon and the linguistic peculiarities of native territories were influenced by the quality and quantity of the migrant population, their level of responsiveness and permeability, and the aggressiveness of both the local and folklore environments and the traditions introduced by migrants. In addition to that, in the first half of the twentieth century, the 'blurring' of traditions and the adjustment of the cultural constituents were implicitly affected by the multinational component pertaining to the settlers banished here. In particular, modern field research data contain considerable evidence confirming the fact that from the 1930s to the beginning of the 1950s, the villages of Nyuvchim, Kazhym, and other small places located near the settlements were inhabited by deported Jews, Poles, Ukrainians, Belarusians, Germans, and other nationalities.

Folklore traditions in the settlements of Nyuvchim, Kazhym, and Nyuchpas have not been an object under special study so far. ${ }^{3}$ The first folklore field studies were undertaken by the ethnic musician Prometheus Chistalyov, who mainly sought to record data about song culture. In the period of 1957-1961, he recorded quite a large corpus of song texts of different genres from local bands and talented individual performers. Work with Chistalyov's field diaries and sound recordings ${ }^{4}$ has enabled us to restore the repertoire lists. ${ }^{5}$ He recorded different genres of non-ritual lyric songs, playing songs, children's folklore, ritual lyric, lamentations, etc. ${ }^{6}$ In the $1960 \mathrm{~s}$, there was no clear setting for recording prosaic genres or any other information pertaining to the spiritual culture of the local population. In this respect, there is a gap in the research of the designated folklore traditions, which began to be filled by modern folklorists only in the first decade of the twenty-first century. Methodical work by means of 'total survey' was done by folklorists of the Institute of Language, Literature, and History in the village of Nyuvchim in 2008, 2011, and 2015, in the village of Kazhym in 2010, 2013, and 2017, and in the village of Nyuchpas in 2011, 2013, and 2017.

\section{RESEARCH METHODS}

Pertaining to the observations related to the formation of the local folklore repertoire, the observations made by Nikita Tolstoy about the forms, means, and 'consequences' of the process of interaction between the cultures that are so different in ethnic terms are of immediate interest. In particular, the point he made about the permeability/non-permeability of different phenomena of folk culture and the inhomogeneous nature of the Slavic folklore genres with respect 
to their susceptibility to foreign folklore and non-folklore fund are particularly significant (see Tolstoy 1995: 53). The researcher lists anecdotes, fairy tales, legends, spiritual verse, and minor folklore genres among the 'susceptible' forms that are 'open' for foreign folklore and non-folklore funds; ritual calendar and family poetry as well as epic poetry are mentioned among 'unsusceptible' and 'closed' genres, the fragments of which can be borrowed 'only with the ritual and the language' (Tolstoy 1995: 53). Andrey Vlasov was more exact when, while talking about the process of formation of the Russian local traditions in the Komi Republic, he pointed out that "the recognition of its own "migratory status", as a matter of fact, its isolation from the surrounding local (even nonethnic) population facilitates the reinforcement in the historical memory of migrants of the traditional forms of folklore culture as the means for reinforcing their "otherness" among indigenous inhabitants, while it also promotes the "birth" of their own world, i.e., the homeland, for further generations' (Vlasov 2007: 13). Vlasov highlights the importance of differentiating between the 'inherited' (which includes the elements of mythological worldview, traditional song forms, ritual folklore, fairy-tale prose, etc.) and 'newly acquired' (historical or legendary prose, the details of ritual complexes, new song growth, toponymy) folklore fund (Vlasov 2007: 13-14).

Taking those assumptions into account, let us make some observations concerning the acquired folklore, which was formed in the new territory, and the hereditary folklore, brought by migrants and containing references to their homeland: historical prose related to the iron-ore industry and the set of Christmas rituals of the Russian population in the settlements of plant workers in the republic (see Krasheninnikova \& Nizovtseva 2019).

It bears repeating that I have had a chance to study those traditions at quite a late stage of their existence. In this respect, a few details should be pointed out. Firstly, the lack of earlier records allows us to describe the synchronous cross-section of the tradition. Taking the age of informants into consideration, we can discuss the state of the tradition in the first third of the twentieth century. Secondly, there was an influx of banished settlers and recruited population in the twentieth century, which resulted in changes in the structure of the basic oldtimer population. Finally, the stability of the oral historical memory of the local population is provided for by local enthusiasts and lore specialists; as a matter of fact, the 'designing' of collective historical memory in the twentieth century took place through the active participation of the mass media and book culture and the staff of local museums, schools, and libraries. The familiarization with the materials that were published in the local press (newspapers, magazines) and their comparison with the records made during field studies enable us to say that some of the plots that were widespread in the oral tradition had been introduced into it, in particular, owing to the range of sources listed above. ${ }^{7}$ 


\section{SOURCES AND MECHANISMS OF FORMATION OF THE REPERTOIRE OF ORAL HISTORICAL PROSE}

The stock of the oral prose within the traditions listed above is much wider. However, a major part of the recorded field data is related to the iron-foundry and metallurgical industries. In this prose, the worldview attitudes of the migrants were reflected as well as the events related to the reclaiming and settling of the territory, the birth and development of production, information about local dynasties, and references to authentic historical persons. The most popular are the motifs about the migration of peasants from the Russian governorates; the motif of establishing ore businesses as a result of selling/ buying the deposits (land) or people to cover gambling debts; the motif of the reclamation and development of space, turning uninhabited foreign space into someone's own and habitable; and the motif about connections between the Urals and Saint Petersburg. Time coordinates are actualized; for example, the time of establishment of ore businesses related to the rule of the empresses Elizaveta Petrovna (Elizabeth) and Catherine the Great, as well as geographical coordinates (migrants come from inhabited localities in Vologda, Vyatka, Arkhangelsk, and Perm governorates, and Siberia). Some of the motifs and images are local and are only typical of certain settlements; for example, the motif of the special part played by industrialist Demidov ${ }^{8}$ is typical of the village of Kazhym, while in the Nyuvchim tradition, texts describing the elaborate image of Emperor Nicholas II and the motif of the connection between the tsar's family and the Nyuvchim plant are recorded.

In stories about ancestors, etiological motifs (the origins of family lines, the specification of topographic and historical coordinates of the native land of the ancestors, etc. ${ }^{9}$ ) are extremely laconic, and the image of the ancestral home of the first settlers does not have any specific outlines. In texts recorded from different informants, the motif of the migration of peasants from the Russian governorates, i.e., Vologda, Vyatka, Arkhangelsk, and Perm governorates, and others, is actualized, but it is realized to a very small degree (sometimes by a single mentioning), for example:

The industrialist bought peasants and moved them here. They settled down here, mixed with the locals, felt at home among them, so to say. They were brought here from the Kirov and Vyatka Oblasts... ${ }^{10}$

Bonded peasants from Arkhangelsk and Vologda, when the settlement was established, bonded peasants were sold. They were brought here from Vologda, Arkhangelsk, and Kirov, and they settled down here, and their customs and traditions also remained. ${ }^{11}$ 


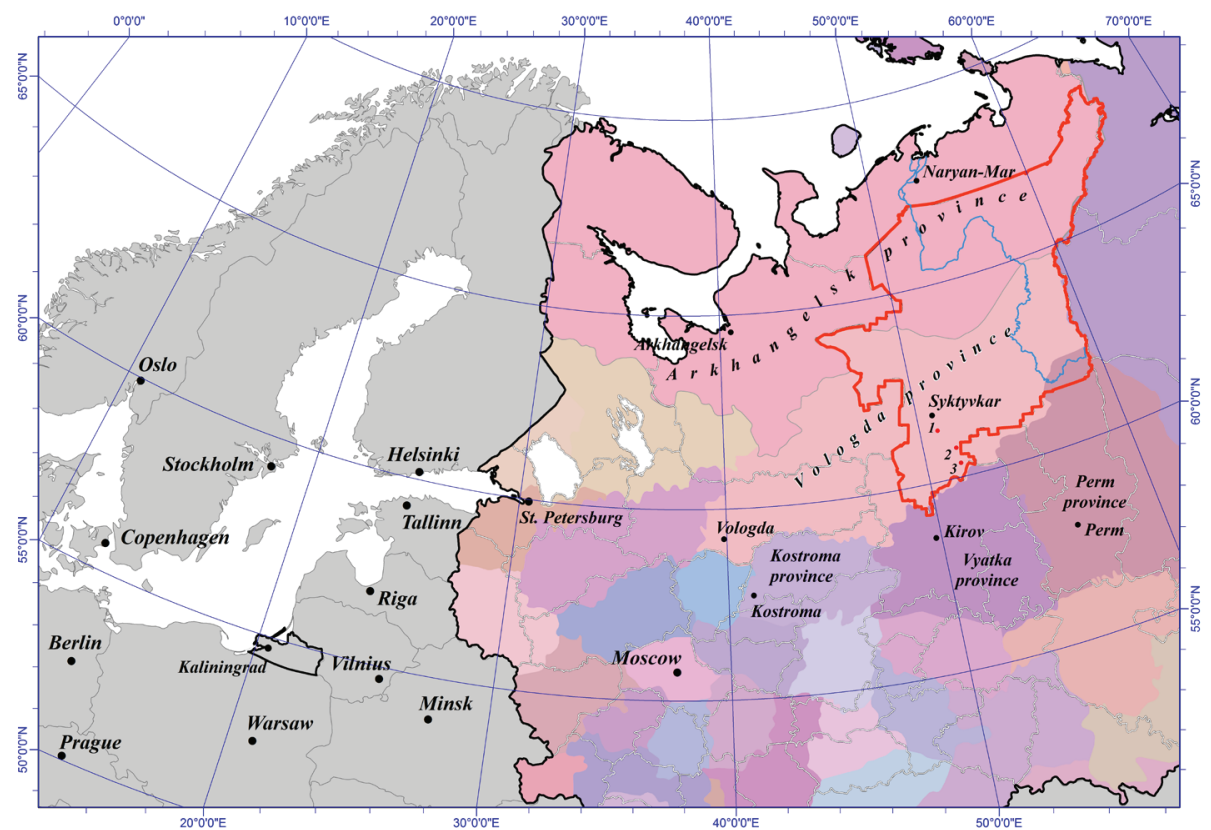

Figure 1. The colored areas of the map illustrate the administrative divisions in Russia in 1914. The black line marks the contemporary borders of Russia; the red line marks the contemporary borders of the Komi Republic. The location of iron industry settlements in the Komi Republic: 1 - Nyuvchim (Syktyvdinsky District), $\mathbf{2}$ - Kazhym, and $\mathbf{3}$ - Nyuchpas (Koygorodsky District). The map is contributed by Vladimir Elsakov and Leonid Rybin (Institute of Biology of Komi Science Centre of the Ural Branch of the Russian Academy of Sciences).

Some texts contain hereditary patronyms, which are represented by informants as an indication of their native homeland:

My mother's surname is Soboleva, they brought the Sobolevs and the Savelyeus from Vologda Governorate... ${ }^{12}$

Where were our grandfathers brought from? They were brought from Vologda Governorate, from there. ... Somewhere in Perm Governorate ... there is the entire village of the Semyachkovs [last name - Y.K.], and they were sent here from over there. She [the local lore specialist - Y.K.] read somewhere in the archive that the two Semyachkov brothers came here in $1816 . .{ }^{13}$

There are mainly Siberians here. Surnames like Usatov, Kuvardin, Kurdyukov. ${ }^{14}$ 


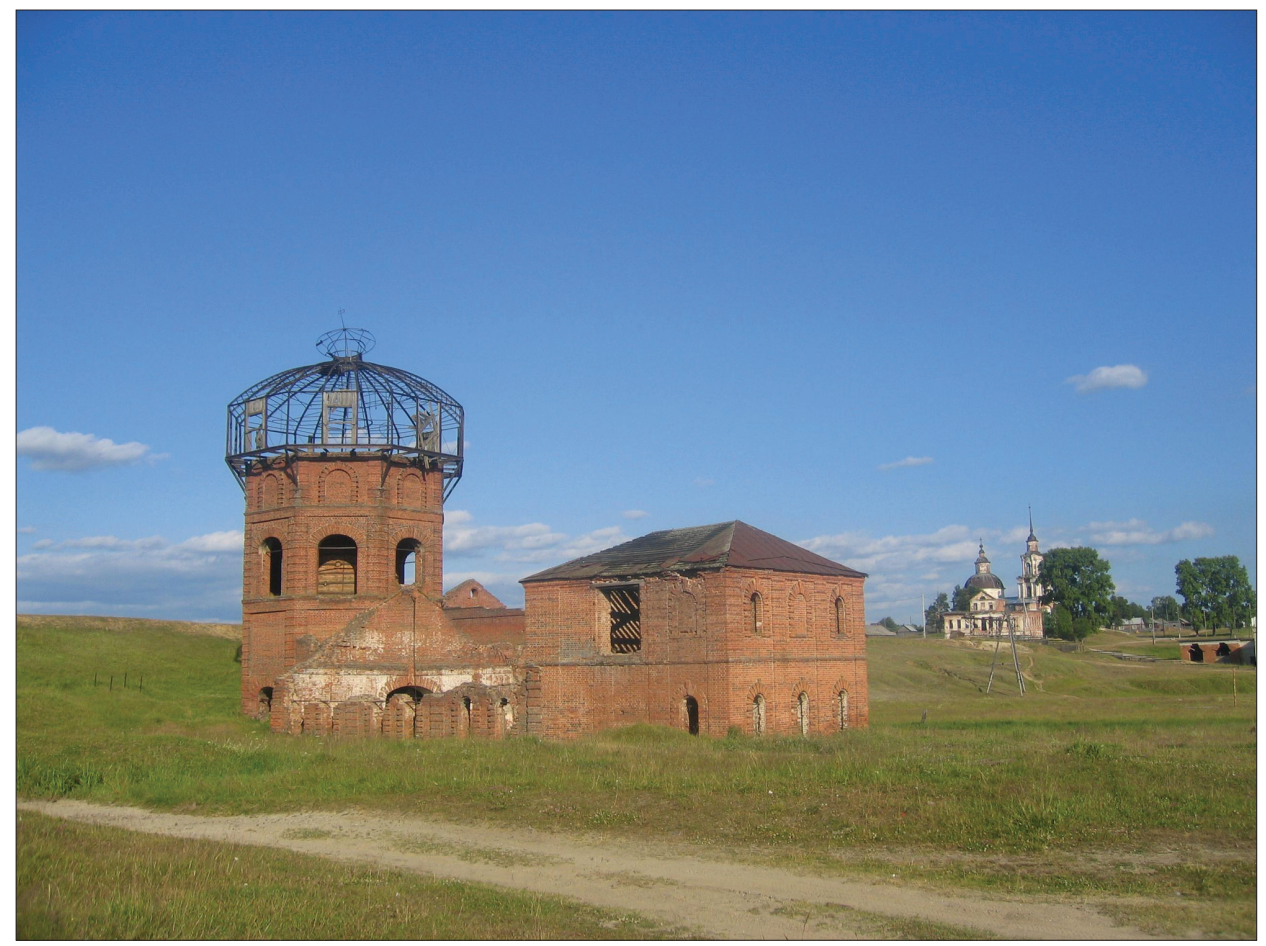

Figure 2. Building of an iron foundry; in the background the Church of St. Dimitry of Rostov. Settlement of Kazhym, Koygorodsky District. Photograph by Yulia Krasheninnikova 2010.

In terms of their meaning, some folklore records refer us to published material about the history of the local industries, which apparently was used during school, museum, and production events and appeared in newspaper articles.

The memory about the homeland of the first settlers was embedded in a number of patrimonial nicknames: the Vaganovs - ancestors from the Vaga River in Arkhangelsk Oblast; the Solins - from the town of Solvychegodsk; the newcomers from Kirov Oblast to the village of Kazhym were referred to as Kirov bast shoes, because they were wearing bast shoes. ${ }^{15}$

In oral stories, time coordinates are recorded. For example, the time period of the establishment of the industry is aligned with the rule of the empresses Elizaveta Petrovna and Catherine the Great. According to one of the versions, the discovery of bog ore deposits near the village Nyuvchim took place during the rule of Elizabeth (1741-1762). 
During the rule of Elizabeth II, one industrialist found ore in bogs, rusty stones, iron. And he decided to build a plant here and smelt ore. The first smelting took place in 1742. There were thick woods over here. He brought bonded peasants from Kirov Oblast and other oblasts, he bought [them]. And then they built houses here, and they built a wooden plant and started smelting ore... ${ }^{16}$

The version about Catherine the Great (who ruled from 1762 until 1796) was more widespread. Catherine the Great sent people from Siberia to Kazhym, and among the first settlers here were Siberians with the surname of Kuvardin; ${ }^{17}$ she came to Kazhym herself to supervise the organization of the work at the plant, and sent plant workers here who started to develop the industry; ${ }^{18}$ she gambled away the land, on which ore was found later on; ${ }^{19}$ she sent bonded peasants from the Volga region to develop the industry.

I was always asking about why we are not the Komi, even though we were born in the Komi Republic. And my grandfather told me that... Catherine the Great would expel bonded peasants from the Volga region and send them to develop the ore industry, there're ironworks here. ... And our ancestors on my mother's side, on her parents' side, are from the Volga region... ${ }^{20}$

All of the events related to the development of the plant and deportation of people are referred by some of the informants only to the rule of Catherine the Great.

- Peasants were brought [P. P.]. Oh, it happened during Catherine's rule! It's a long story [D. P.]. People were brought here from the Volga River... [P. P.]. They were bought and sold many times, the old ones. The Tvorozhnikovs, Kolesovs, Smyachkovs, and Anisimovs. All of these surnames come from different governorates.

- How did they get here?

- Perhaps they were brought here to work. I think Kosolapin as well. The plant was built during Catherine's rule, it was written somewhere, I read it somewhere; all of these workers were brought from different governorates. ${ }^{21}$

The motif of the establishment of the ore industry as a result of the sale/purchase of the deposits (land) or people to cover a gambling debt is also very consistent. In different texts, the land and peasants were gambled away 'from one landowner to another', by merchants, or Catherine the Great; the settlement and the ancestors of its modern inhabitants are referred to as 'gambled away', 'deported from Russia on account of her debt', 'purchased and sold', 'slaves that 
were gambled away', and 'bonded peasants'. In numerous texts and laconic evidence the idea of the forced migration of peasants is actualized: firstly, by calling the migrants as 'slaves' or 'peasants'22; secondly, the process itself is regarded as a negative one to be disapproved of, which is represented by the verb to send away 'to make someone leave, to move out of the borders of something, to exile (usually by the decision of an administrative or judicative authority)' (Yefremova 2000), and also by more neutral verbs, such as to bring 'to deliver somewhere by carriage' (Ushakov 1939: column 768), to send 'to dispatch, to refer to, to send on an errand', which also take on a negative connotation in the context of talking about the forced nature of migration.

- Catherine gambled away the settlement, she gambled it away. They sent the entire settlement here, to Kazhym.

- There was nothing here?

- There was nothing here.

- Did she gamble away the land?

- No, people...

- Was it a gambling debt?

- I don't know, I don't know anything about a gambling debt, but I heard that our settlement had been gambled away, we are the exiled ones. Our ancestors were exiled from Russia. And there were only Russian people here. In Koigorodok, there were the Komi. And we had all Russians here. ... We are the exiled ones. Our ancestors, not my parents, but their parents, they are buried here, too, they were gambled away, two hundred years ago, I think. Our whole settlement was gambled away. ${ }^{23}$

- Well, when they were gambled away, the Demidovs were brought here, our grandfathers and great-grandfathers. And they just settled down here. - What do you mean by being gambled away? Who gambled them away? - The director. They were somewhere near Moscow, our great-grandfathers. And some merchant gambled them away, it was a gambling debt, to the Demidovs. And the Demidovs... brought them here to Nyuvchim... ${ }^{24}$

While describing the staff of the plants at the Sysola River, historians point out that state peasants of voluntary recruitment, who had been trained to work at the plant, were working at the plants as craftspeople, and peasants were only bought in small numbers at the end of the eighteenth to the beginning of the nineteenth centuries (Politov 2005: 109, 112). In addition to that, in scientific and popular scientific publications of the twentieth century the idea about serious distress and hardships experienced by plant workers ('bonded labour', 
'enslavement') is emphasized, and the researchers talk about legal and illegal measures taken by plant owners in order to keep the workers at the plant and turn them from 'people with personal freedom into plant slaves' (Politov 2005: 110), about the 'half-villeinage system' of supply of the industry with labour force in its essence (Surina 1973: 25), and many others. It is possible that these statements, alongside other factors, had an impact on the emergence of texts with the motifs described above in the local prose.

One of the first mentions about peasants that assumedly had been gambled away was found in an essay by Alexander Anisimov (1924). This local lore specialist cites 'a true story', according to which the peasants from Kadnikovsky Uyezd, leaving for 'the unknown land', 'into a thick wood inhabited by wild animals and the wild Zyrians', 'collected their stuff and went to the new landlord - the plant owner [apparently, it is about Gribanov - Y.K.]', because 'they heard that the landlord had gambled them away to Gribanov' (Anisimov 1924: 61-62). The motif of selling something (land, people) on account of a gambling debt, which is very widespread in the folklore and literature tradition ${ }^{25}$ as well as precedent-setting facts that took place in real life, gave an impetus to the generation of the corpus of folklore texts with the motifs of playing cards and gambling debts. It also appears in the reminiscences that describe the everyday life of the local people of Nyuvchim. Informants specify that playing cards was one of the best-loved pastimes of plant owners:

Everyone was playing here. Everyone was playing cards here, they gambled away cows and everything else. An old man lived here, Nikanor's father, and he played cards until his cow was taken away from him. Yes, many people were gambling away cows. ${ }^{26}$

Quite often the motif of being connected to Saint Petersburg is realized in texts, which was furthered by the information that often comes up in publications about private plants fulfilling state orders and participating in the industrial life of the country. For example, Butlerov, the last pre-revolutionary owner of the plant, lived in Saint Petersburg: '... the last plant owner was Butlerov, either before or immediately after the revolution. It does not say that anywhere, but he had an oval-shaped stamp saying "Plant Owner Butlerov". ... Butlerov lived in Saint Petersburg'. ${ }^{27}$ The Nyuvchim plant is referred to as the 'Treasury', which is indicative of the fact that it was recognized as a state company: 'It used to be called the Treasury, not the plant. People were working at the Treasury. [They said]: "We are working at the Treasury...". ${ }^{28}$ There is reliable information proving that cast iron and iron produced at the plants in Nyuvchim and Kazhym were used when casting the gates and the roofs of the Winter Palace in Saint 
Petersburg. It is curious that the informants from Kazhym also mention other buildings in Saint Petersburg ('the roof of some church is covered with the iron made here'29, 'it was even taken to Saint Petersburg and used to roof the building in tsarist times... ${ }^{30}$ ) and in Moscow. The active pedalling of this topic by the inhabitants of Kazhym and Nyuvchim, their 'competitiveness' for the right to be involved in one of the historical and cultural 'centres' of Russia is one of the most significant facts of the local social 'biography'. Informants speaking about a large silver medal that in 1896 was awarded at the All-Russian Product Fair in Nizhny Novgorod for 'office casting' made at Nyuvchim ${ }^{31}$ (in folk local terms: 'coloured', 'shaped' casting) misinform collectors unintentionally, saying that the medal was also awarded for the production made in Kazhym:

The tsar's palace in Saint Petersburg was covered with Kazhym iron. ... Even in 1896 at the All-Russian Product Fair in Nizhny Novgorod Kazhym iron, and the products made from it, and from cast iron, were awarded with a small golden medal. ${ }^{32}$

Finally, two more motifs are distinguished in the local prose, which are spread locally and related to the description of the life of some people that were famous in Russian history. In the folklore prose of the village of Kazhym, a regular motif concerns the special role played by the industrialist Demidov in the organization and development of the local ore industry. ${ }^{33}$ The belonging of the local ore industry to the Urals and a group of the Ural plants (quite often the local plants are referred to as 'Demidov's plants') is highlighted in texts, and Demidov has the attributes of 'being in charge of iron foundries', 'the main leader', 'the only owner', who was sending people from the Urals and Siberia to work at the local plants. The local population associates the establishment of the plant in the village of Kazhym with Demidov's initiative, emphasizing that the local blast furnace was built by the type of the Ural ones ${ }^{34}$, or pointing at the equivalence between the organization of the Ural and Kazhym production ('We had similar dams, and the plants were similar. But this Demidov also had plants [about the plants in Nyuvchim and Nyuchpas - Y.K.]. ${ }^{35}$ Either by Demidov himself or by his order, exploration surveys were done in order to organize production.

Overall, these were Demidov's plants. Demidov was obviously sending people here to found iron ... Well, yes, Demidov was their main boss. He also had some assistants, they were managing the plant on the spot. I think the old people say that Demidov never even came here, not even once. ${ }^{36}$

And, finally, in one of the texts Demidov is referred to an inhabitant of Kazhym, a native of the village, a member of the local population, i.e., 'their own': 
- Have you heard the surname of Demidov?

- Demidov, yes, of course, he was local, from Kazhym, I think he was the manager ..., my mother said that to me once.

- Was he the manager? Was it his plant?

- Yes, it was his plant, you're right. ${ }^{37}$

Why does the image of Demidov appear in the local prose? According to the historical data, none of the Demidovs visited the local plants, but the name of Demidov is related to the beginning, development, and blossoming of the mining and metallurgical industries in Russian history. Apparently, the longlasting associative link of 'mining - iron foundry - Ural - Demidov' 'went off' at the level of folklore consciousness and gave an impetus to the emergence of the image of Demidov. By the way, this association has been implicitly used in local publications in the twentieth and twenty-first centuries, which tell about the history of the emergence of the industry in question. ${ }^{38}$ In local oral prose, Demidov has neutral characteristics, while in a number of texts he is also assigned with positive properties: to some extent he appears as a demiurge, the discoverer of the industry, who had the creative powers, skills, and knowledge required for the establishment and development of the plants. ${ }^{39}$

In the oral prose of the village of Nyuvchim the motif of blood relations with the tsar's family was recorded. In this respect, the image of the last Russian emperor Nicholas comes up. According to one of the adaptations, the manager Vassily Kosolapov (who was actually the manager while manufacturer and landowner Dmitry Bernadaki was the owner of the plant in 1880) was a secret son of the tsarist dynasty who brought his new-born son Sergey to Saint Petersburg to 'show him to his grandfather Emperor Nicholas and Empress Maria'40, while in other texts he was referred to as the 'emperor's servant', and the latter was referred to as the owner of the plant. In yet another source the emperor is referred to as 'a trustee' of the emerging industry, who was recruiting labour force, while his sister would bring them to these territories:

Emperor Nicholas gathered all of them together, the emperor from Saint Petersburg, he gathered all of them. The emperor's sister came over here and brought all of them. Well.... about two hundred people. Yes, he brought $236^{41}$ people here, Nicholas the emperor. ${ }^{42}$

The empress also took part in the development of the industry, and one of the texts tells about her intention to build a railway from the Pechora River to Nyuvchim:

Even Maria, the emperor's wife, ... wanted to build a railway from the Pechora River to Nyuvchim. Well, you see, when the White Army attacked, 
the war began. ... Valentin [informant's husband - Y.K.] would go hunting almost every Saturday and saw iron rail tracks, and on the rail tracks it was written: "Maria was here, Maria the empress." This is what was written on them. You see, they even wanted to build a railway from the Pechora River to Nyuvchim, for trains to travel here. She was Nicholas the emperor's wife. ${ }^{43}$

Another text was related to the image of the emperor-visionary and prophet:

[The emperor to Nyuvchim] Yes, he came here, he came indeed, but very long time ago. My mother told me that he did, without fanfare. The White Army was attacking. Without Maria. He wanted to see how Kosolapov was doing, he had hired him to manage this place. And he liked it, he liked everything here. They were sowing bread wheat, barley, groats, they did everything here. People were working because Kosolapov made them work. He would throw people out if they didn't work. [The emperor] praised Kosolapov a lot. But he warned us about what was coming, the year 1917. And in 1917, the revolution happened. It was such a mess in 1917. They turned everyone out, and we had been working so well here at the foundry. [The emperor] warned us not to work for them. ${ }^{44}$

In the narratives, Emperor Nicholas and representatives of the royal family are depicted as the founders and trustees of the industry, who express an interest not only in the development of the plant itself, but also its infrastructure (for example, the construction of the railway). The peculiar features of the characters (the motif of the secret arrival and staying in Nyuvchim, the ability to foretell the future, etc.) that are typical of the mythological image of a 'cultural hero' are highlighted in texts. ${ }^{45}$

\section{CONCLUSION}

The worldview paradigms of migrants, events related to reclaiming and inhabiting the territory, and information about local dynasties and historical figures, during the rule of which the plants operated and developed, were topics that were reflected in the historical prose of the Russian population living in mining and metallurgical settlements throughout the republic. It is worth mentioning that the structuring of collective historical memory in the twentieth century took place through the involvement of the mass media, book culture (on the part of local enthusiasts), local lore specialists, and the staff of local museums, schools, and libraries. This analysis of historical traditions allows us to record 
the process of active incorporation of information about historical events and famous historical figures of a Russian-wide scale into local chronicles, which served as a link between migrants and their Great Homeland, and enabled them to get involved in the Russian historical context, marking down the most significant landmarks of the local history.

\section{ACKNOWLEDGEMENTS}

This research was carried out within the research project No. 16-14-11001a(r), supported by the Russian Foundation for Basic Research and the government of the Komi Republic, and research project No AAAA-A17-117021310066-4.

\section{NOTES}

1 There are discrepancies pertaining to the dates of the commissioning of the Kazhym and Nyuchpas plants. In particular, Igor Zherebtsov writes that the plants had been in operation since 1759 (Zherebtsov 1994: 85, 167).

2 'Superimposed' elements can also be found in material culture: ethnographers do not rule out the influence of the types of dwellings typical of the areas that the newcomer plant workers came from, in particular, from the territories of Vyatka Governorate and 'especially Perm Governorate' (Zherebtsov 1962: 132-133); in terms of clothing, particular plant and urban characteristics were present; within the material culture of the village of Nyuvchim, the tradition of lace-making was preserved (making lace on bobbins), which was not typical for the local Komi culture but had a rich tradition in the nearby Vologda territories (Bandura \& Krasheninnikova 2011: 122) and others.

3 As a side note, in the Russian archives, rare recordings about the iron-ore industry in the Komi Republic have been discovered. For example, in the archive of the Russian Museum of Ethnography, there is material recorded by correspondent V. Pokrovsky in Koygorodsky municipality of Ust'-Sysolsky Uyezd in 1898, including at the Kazhym and Nyuchpas iron-ore plants (Archive of the Russian Museum of Ethnography. F. 7. Op. 1. D. 382, 370, 371), which contains very scarce and odd bits of information about plant settlements, production management, and the way of life of the local people (see Russian peasants 2008: 437-458). The documents from the pre-revolutionary period, mainly of statistical and production nature, are archived at the National Archive of the Komi Republic (funds 162-164). Individual items of information about the owners, the amounts of smelted ore and the number of plant workers as well as the channels selling the produce were discovered in documents in the Department of Manuscripts at the National Library of Russia (FXVII-111. L. 4-5). Information about the folklore culture of the local population was not recorded in the archives specified above.

${ }^{4}$ Field diaries are stored in the museum collections of the National Museum of the Komi Republic, and sound recordings are archived at the Folklore Fund of the Institute of Language, Literature, and History of the Komi Scientific Centre of the Ural Branch of the Russian Academy of Sciences. 
5 They have been partially published (see Krasheninnikova 2010).

6 It should be pointed out here that during the field research conducted in 2008-2017, only individual texts and fragments of song, game, and children's folklore as well as ritual and non-ritual lyrics were recorded, and within this context, the records made by Chistalyov are of extreme importance and value.

7 Many informants say that they learned some of the facts about the origins of settlements and plants, the range of product output, and the everyday life of plant workers and their years in the military from excursions and lectures organized by representatives of local museums and schools. The analysis of newspaper and magazine publications at the end of the nineteenth and in the twentieth centuries has demonstrated the stability of the following plots: the discovery of ore deposits and the birth of production, the social and economic status of plants in different time periods, the range of product output, and overviews of exhibitions, which also included information about the fact that the first settlers were peasants coming from different parts of Russia as well as about the owners and the relevance of the plants. Information about the participation of plants in the industrial life of the country, fulfilling special government and military orders, the so-called 'office casting' is also available.

8 The reference here is to the Demidovs' clan, not an individual member.

9 See Razumova (2001: 188-190) about these markers of family and biographical stories.

${ }^{10}$ Recorded by Y. Krasheninnikova in Nyuvchim, on 17 September 2008, from A.I. Silin, born in Nyuvchim in 1928. Every cited material is accompanied by a note containing information about the place and the year of the recording, the initials (name, patronymic name) and last name, and the year and place of birth of the respondent.

${ }^{11}$ Recorded by Y. Krasheninnikova in Nyuvchim, on 17 September 2008, from G.V. Silina, born in Yaroslavl Oblast in 1930.

${ }^{12}$ Recorded by Y. Krasheninnikova in Nyuvchim, on 17 September 2008, from E.P. Vorotnyova, born in Nyuvchim in 1927.

${ }^{13}$ Recorded by Y. Krasheninnikova in Nyuvchim, on 2 June 2015, from L.V. Semyachkov, born in Nyuvchim in 1944.

${ }^{14}$ Recorded by Y. Krasheninnikova in Kazhym, on 3 July 2010, from N.K. Usatova, born in Ust-Kulomsky District of the Komi Republic in 1938.

${ }^{15}$ Recorded by Y. Krasheninnikova in Kazhym, on 23 June 2013, from A.A. Burylova, born in the village of Bolshoy Kashnur in Kirov Oblast in 1933.

${ }^{16}$ Recorded by Y. Krasheninnikova in Nyuvchim, on 17 September 2008, from A.I. Silin, born in Nyuvchim in 1928.

${ }^{17}$ Recorded by Y. Krasheninnikova in Kazhym, on 3 July 2010, from P.I. Usatov, born in Kazhym in 1932.

${ }^{18}$ Recorded by Y. Krasheninnikova in Kazhym, on 6 July 2010, from A.A. Burylova, born in the village of Bolshoy Kashnur, Kirov Oblast, in 1933. 
${ }^{19}$ Recorded by Y. Krasheninnikova in Kazhym, on 2 July 2010, from L.V. Vavilova, born in Kazhym in 1930.

${ }^{20}$ Recorded by Y. Krasheninnikova in Kazhym, on 2 July 2010, from I.N. Kharina, born in Kazhym in 1923.

${ }^{21}$ Recorded by L. Lobanova and E. Fedoseyeva in Nyuvchim, on 18 November 2011, from P.A. Popov, born in Pevka in Syktyvdinsky District of the Komi Republic in 1929, and D.A. Popova, born in the village of Vizinga in Sysolsky District of the Komi Republic in 1931.

${ }^{22} \mathrm{~A}$ bonded peasant is a person that is bound under the feudal system, i.e., he or she does not have any civil or property rights (see Linguistic Dictionary).

${ }^{23}$ Recorded by Y. Krasheninnikova in Kazhym, on 24 June 2013, from E.A. Chistoprudova, born in Kazhym in 1936.

${ }^{24}$ Recorded by Y. Krasheninnikova in Nyuvchim, on 9 June 2015, from S.I. Vasilyev, born in Nyuvchim in 1937.

${ }^{25}$ Playing cards as a 'unique model of life', 'model of public life' (Lotman 1994: 136, 148) occupied the leading position among other games in the pastime of the Russian society in the eighteenth and nineteenth centuries (Komissarenko 2003).

${ }^{26}$ Recorded by Y. Krasheninnikova in Nyuvchim, on 4 June 2015, from L.P. Vasilishina, born in Nyuvchim in 1937.

${ }^{27}$ Recorded by Y. Krasheninnikova in Nyuvchim, on 17 September 2008, from A.I. Silin, born in Nyuvchim in 1928.

${ }^{28}$ Recorded by Y. Krasheninnikova in Nyuvchim, on 16 September 2008, from A.M. Sokolova, born in Nyuvchim in 1927.

${ }^{29}$ Recorded by Y. Krasheninnikova in Kazhym, on 3 July 2010, from V.N. Filyov, born in Kazhym in 1934, and from T.S. Filyova, born in Brest Oblast, Belorussia, in 1934.

${ }^{30}$ Recorded by Y. Krasheninnikova in Kazhym, on 5 July 2010, from V.A. Chegletsov, born in Kazhym in 1929, and from G.P. Chegletsova, born in Smolensk Oblast, Belorussia, in 1930.

${ }^{31}$ See Zelensky and Krasheninnikova and Bandura 2009 about artistic casting done at Nyuvchim iron foundry.

${ }^{32}$ Recorded by Y. Krasheninnikova in Kazhym, on 2 July 2010, from G.P. Lozitskaya, born in Kazhym in 1948.

${ }^{33}$ In Nyuvchim we were only able to record a single text related to the image of Demidov.

${ }^{34}$ Recorded by Y. Krasheninnikova in Kazhym, on 24 June 2013, from D.N. Shishnyov, born in Kazhym in 1932.

${ }^{35}$ Recorded by S. Nizovtseva and A. Rassykhayev in Nyuvchim, on 15 November 2011, from T.P. Raykhert, born in Nyuvchim in 1950. In the popular scientific paper "Ha далекой окраине. Как жили и боролись за свои права рабочие Коми края" (On 
the far-off outskirts: The way the workfolk on the territory of the Komi lived and fought for their rights), published in Syktyvkar in 1973, in an edition of 2,500 copies, we find the following: 'Metallurgical plants on the territory of the Komi had much in common with the Ural mining plants. They had this intrinsic "original formation" of the Uralian industry, which was described by V. I. Lenin...' (Surina 1973: 24).

${ }^{36}$ Recorded by Y. Krasheninnikova in Kazhym, on 3 July 2010, from P.I. Usatov, born in Kazhym in 1932.

${ }^{37}$ Recorded by S. Nizovtseva and P. Shakhmatskaya in Kazhym, on 22 June 2013, from G.A. Karavaeva, born in Kazhym in 1939.

${ }^{38}$ For example, in the essay "Кажимские горные заводы" (Mining Plants in Kazhym), when the history of their foundation is described, the image of a blacksmith from Tula named Demidov comes up: 'The desire to get rich fast was very tempting, and the laurels of a simple blacksmith from Tula named Demidov, who found fame, rank, honour, and wealth very fast, owing to his factories and plants, haunted the minds of the men of enterprise of the time' (Anisimov 1924: 59). In an essay about the Kazhym metallurgical plant, the 'rewarding experience of Demidov' is mentioned: '... the merchants from Ustyug (bearing in mind the rewarding experience of Demidov in the Urals) made a focused attempt at mineral exploration...' (Culture 2004: 62), and others. Obviously, the historical feature film "Demidovy" (The Demidovs), which was aired in 1983, should also be mentioned here. It has had a wide response, owing to which the image of Demidov could appear in local prose (I would like to thank V. Survo for this idea).

${ }^{39}$ By the way, in the historical prose of the Urals, it was the tsar Peter the Great who was attributed with such features, while Demidov appeared as 'an evil soul-taker' (Golovanov 2010: 131, 137-138).

${ }^{40}$ Recorded by Y. Krasheninnikova in Nyuvchim, on 17 September 2008, from E.P. Vorotnyova, born in Nyuvchim in 1927.

${ }^{41}$ It is a curious fact that the informant mentions a specific number that also came up, in particular, in newspaper publications and popular scientific reference books (e.g. Zherebtsov 1994: 166).

${ }^{42}$ Recorded by Y. Krasheninnikova in Nyuvchim, on 17 September 2008, from E.P. Vorotnyova, born in Nyuvchim in 1927.

${ }^{43}$ Recorded by Y. Krasheninnikova in Nyuvchim, on 17 September 2008, from E.P. Vorotnyova, born in Nyuvchim in 1927.

${ }^{44}$ Recorded by Y. Krasheninnikova in Nyuvchim, on 17 September 2008, from E.P. Vorotnyova, born in Nyuvchim in 1927.

45 The plot with the image of Emperor Nicholas deserves separate consideration, and I will only point out some individual aspects here. Almost all of the texts with the images of the representatives of the royal dynasty were recorded in 2008 from one informant who had been born and was living in Nyuvchim - a settlement located in the vicinity of Ust'Sysolsk (the current Syktyvkar). It would be tempting to assume that the appearance of Emperor Nicholas in the local prose could be influenced by information about the official visit to Ust'-Sysolsk of the Grand Duke Sergey Alexandrovich of Russia (who 
was the uncle of Emperor Nicholas, the last emperor of Russia), which took place on 3 June 1898 with the aim of becoming familiar with the military administrations of Vologda Governorate. The visit from the representative of the House of Romanov was described in detail in Vologda eparchial news bulletins. Leaving out the details of the visit, I will only mention that the programme of the stay included a visit to a local exhibition, which was set up outside of the building of Ust'-Sysolsk local government. At the exhibition, samples of graded wood meant to be exported abroad as well as forestry and timber industry products, samples of leathermaking industry, agricultural tools and crops, products of Nyuvchim metallurgical plant (author's emphasis - Y.K.) and the log sawing facility, Zyrian clothing, fishing and hunting tools, etc. were on display (VEV 1898: 608-609). According to my findings, this topic did not get a wide media coverage, because it was not popular enough; and the plot of a visit paid to Ust'-Sysolsk by the Grand Duke re-emerged and was debated significantly at the beginning of the twenty-first century.

\section{REFERENCES}

Anisimov, Aleksandr 1924. Kazhimskie gornye zavody (K materialam po istorii gornozavodskoi zhizni v Komi oblasti). [The Mountain Plants in Kazhim (To Materials on the History of Mining Life in the Komi Area).] Komi mu, No. 4-5, pp. 58-63; No. 7-10, pp. 40-44.

Bandura, Svetlana \& Krasheninnikova, Yulia 2011. Kul'turnoe nasledie Niuvchima: iz opyta prezentatsii muzeinoi kollektsii cherez fol'klornyi tekst. [Cultural Heritage of Nyuvchim: Experience of the Presentation of a Museum Collection through Folklore Text.] In: A. Kargin (ed.) Slavianskaia traditsionnaia kul'tura i sovremennyi mir. Vyp. 14: Kompleksnye issledovaniia traditsionnoi kul'tury $v$ postsovetskii period: sbornik nauchnykh statei. Moscow: Gosudarstvennyi respublikanskii tsentr russkogo fol'klora, pp. 121-130. Available at http://www. folkcentr.ru/slavyanskaya-tradicionnaya-kultura-i-sovremennyj-mir-vypusk14-kompleksnye-issledovaniya-tradicionnoj-kultury-v-postsovetskij-period/, last accessed on 2 July 2019.

Culture 2004 = Kazhimskii zhelezodelatel'nyi zavod (1755-1927 gg.). [Kazhim Ironworks Plant (1755-1927).] Kul'tura: izdanie Informatsionnogo tsentra kul'tury i iskusstva Respubliki Komi, No. 8, pp. 62-64.

Golovanov, Igor 2010. Mifologicheskie obrazy v fol'klornoi istoricheskoi proze Urala. [Mythological Images in Folkloristic Historical Prose of the Urals.] In: A. Kargin (ed.) Obraznyi mir traditsionnoi kul'tury: Sbornik statei. Moscow: Gosudarstvennyi respublikanskii tsentr russkogo fol'klora, pp. 129-140. Available at http://www.folkcentr.ru/obraznyj-mir-tradicionnoj-kultury-sbornik-statejm-gosudarstvennyj-respublikanskij-centr-russkogo-folklora-2010-352-s/, last accessed on 2 July 2019.

Komissarenko, Svetlana 2003. Igra v karty kak kul'turnaia traditsiia russkogo obshchestva XVIII-XIX vv. [Card Play as a Cultural Tradition of the Russian Society in the 18th-19th Centuries.] In: S. Komissarenko. Kul'turnye traditsii russkogo obshchestva. St. Petersburg: SPbGUP, pp. 88-106. Available at 
https://statehistory.ru/2266/Igra-v-karty-kak-kulturnaya-traditsiya-russkogoobshchestva-XVIII-XIX-vv-/, last accessed on 2 July 2019.

Krasheninnikova, Yulia 2010. Polevye dnevniki P.I. Chistaleva kak istochnik dlia izucheniia pesennoi fol'klornoi traditsii p. Niuvchim. [Field Diaries of P.I. Chistalyov as a Source for Studying Folk Song Tradition of the Village of Nyuvchim.] Muzei i kraevedenie. Trudy Natsional'nogo muzeia Respubliki Komi, Vyp. 7. Syktyvkar: Natsional'nyi Muzei RK, pp. 188-196.

Krasheninnikova, Yulia \& Nizovtseva, Svetlana 2019. Christmas in the Traditions of Russian Mining Settlements of the Komi Republic (as per Records of the Early Twenty-First Century). Folklore: Electronic Journal of Folklore, Vol. 76, pp. 119133. https://doi.org/10.7592/FEJF2019.76.krasheninnikova_nizovtseva.

Linguistic Dictionary = Lingvostranovedcheskii slovar'. [Linguistic and Cross-Cultural Dictionary.] Available at https://lingvostranovedcheskiy.academic.ru/260/, last accessed on 2 July 2019.

Lotman, Yuri 1994. Besedy o russkoi kul'ture. Byt i traditsii russkogo dvorianstva (XVIIInachalo XIX veka). [Conversations about Russian Culture: Everyday Life and Traditions of the Russian Nobility (18th - Beginning of the 19th Centuries).] St. Petersburg: Iskusstvo-SPb.

Politov, Valentin 2005. Promyshlennost' Komi kraia v XVIII v. [Industry of the Komi Region in the 18th Century.] Syktyvkar: Komi nauch. tsentr UrO RAN.

Razumova, Irina 2001. Potaennoe znanie sovremennoi russkoi sem'i: byt, fol'klor, istoriia. [Secret Knowledge of Modern Russian Family: Everyday Life, Folklore, History.] Moscow: Indrik.

Russian peasants 2008 = Russkie krest'iane. Zhizn'. Byt. Nravy. Materialy "Etnograficheskogo biuro" kniazia V. N. Tenisheva. [Russian Peasants: Life. Everyday Routine. Customs. Materials of the "Ethnographic Bureau" of the Duke V.N. Tenishev.] T. 5: Vologodskaia guberniia. Ch. 4: Totemskii, Ust'-Sysol'skii, Ustiugskii i Iarenskii uezdy. Compiled by T. Zimina \& O. Foniakova. St. Petersburg: Delovaia poligrafiia.

Surina, Lidia 1973. Na dalekoi okraine (Kak zhili i borolis' za svoi prava rabochie Komi kraia). [In the Far Periphery (How the Workers of the Komi Region Lived and Fought for Their Rights).] Syktyvkar: Komi knizhnoe izdatel'stvo.

Tolstoy, Nikita 1995. Iazyk i narodnaia kul'tura: Ocherki po slavianskoi mifologii $i$ etnolingvistike. [Language and National Culture: Essays about Slavic Mythology and Ethnolinguistics.] Moscow: Indrik. Available at http://e-heritage.ru/ras/view/ publication/general.html?id=46695533, last accessed on 2 July 2019.

VEV 1898 = Poseshchenie Ego Imperatorskim Vysochestvom Velikim Kniazem Sergeem Aleksandrovichem Vologodskoi gubernii (okonchanie). [Visit by His Imperial Highness the Grand Duke Sergey Aleksandrovich of the Vologda Province (End).] Vologodskie eparkhial'nye vedomosti: Pribaulenie, No. 24. 15 December, pp. 606-617. Available at http://pravoslavnoe-duhovenstvo.ru/media/priestdb/ materialattachment/attachment/99/59/9959f09a-61a5-4473-b8f3-8623d26714a5. pdf, last accessed on 2 July 2019.

Vlasov, Andrey 2007. Prostranstvenno-vremennye granitsy lokal'nykh/regional'nykh traditsii: Opyt opisaniia. [Spatial-Temporal Limits of Local/Regional Traditions: Experience of the Description.] In: M. Alekseevskii \& V. Dobrovol'skaia (comps.) Slavianskaia traditsionnaia kul'tura $i$ sovremennyi mir. Vyp. 10: Sbornik 
nauchnykh statei po materialam konferentsii. Moscow: Gosudarstvennyi respublikanskii tsentr russkogo fol'klora, pp. 7-22.

Ushakov, Dmitriy (ed.) 1939. Tolkovyi slovar' russkogo iazyka. [Explanatory Dictionary of the Russian Language.] Vol. 3. Moscow: Gosudarstvennoe izdatel'stvo inostrannykh i natsional'nykh slovarei.

Yefremova 2000 = Efremova, Tat'iana. Novyi slovar' russkogo iazyka. Tolkovoslovoobrazovatel'nyi. [New Dictionary of the Russian Language. Explanatory and Word-Forming.] Moscow: Russkii iazyk. Available at http://www.efremova. info, last accessed on 2 July 2019.

Zelensky \& Krasheninnikova \& Bandura (comps.) 2009 = Zelenskii, Vladimir \& Krasheninnikova, Iuliia \& Bandura, Svetlana. Khudozhestvennoe lit'e Niuvchimskogo chugunoliteinogo zavoda. [Ornamental Casting of the Nyuvchim Iron Foundry.] Seriia "Raritety". Vyp. 3. Set of postcards. Syktyvkar: Natsional'nyi muzei Respubliki Komi.

Zherebtsov, Igor 1994. Gde ty zhivesh': Naselennye punkty Respubliki Komi: Istorikodemograficheskii spravochnik. [Where You Live: Settlements of the Komi Republic: Historical and Demographic Reference Book.] Syktyvkar: Komi knizhnoe izdatel'stvo.

Zherebtsov, Liubomir 1962. K izucheniiu kul'tury i byta gornozavodskogo naseleniia Komi kraia (II polovina XIX - nachalo XX vv.). [To the Study of Culture and Everyday Life of the Mining Population of the Komi Region (the 2nd Half of the 19th - the Beginning of the 20th Centuries).] Istoriko-filologicheskii sbornik, Vyp. 7. Syktyvkar: Komi kn. izd-vo, pp. 121-138. 


\title{
KAZAKH DIASPORA IN KYRGYZSTAN: HISTORY OF SETTLEMENT AND ETHNOGRAPHIC PECULIARITIES
}

\author{
Bibiziya Kalshabayeva \\ Professor, Department of History, Archeology and Ethnology \\ Al-Farabi Kazakh National University \\ Almaty, Kazakhstan \\ Email:kalshabaeva_b@mail.ru
}

\section{Gulnara Dadabayeva}

Associate Professor, KIMEP University

Almaty, Kazakhstan

Email: gdadabaeva@mail.ru

\author{
Dauren Eskekbaev \\ Associate Professor, Almaty University of Management \\ Almaty, Kazakhstan \\ Email:d.eskekbaev@mail.ru
}

\begin{abstract}
The article focuses on the most significant stages of the formation of the Kazakh diaspora in the Kyrgyz Republic, to point out what reasons contributed to the rugged Kazakh migration process in the nineteenth and twentieth centuries and how it affected the forms and types of their settlements (compact or disperse). The researched issues also include the identification of factors provoked by humans and the state to launch these migrations. Surprisingly enough, opposite to the claims made by independent Kazakhstan leadership in the early 2000s, the number of Kazakhs in Kyrgyzstan wishing to become repatriates to their native country is still far from the desired. Thus the article is an attempt to find out what reasons and factors influence the Kazakh residents' desire to stay in the neighboring country as a minority. To provide the answer, the authors analyzed the dynamics of statistical variations in the number of migrants and the reasons of these changes. The other key point in tracing what characteristic features separate Kazakhs in Kyrgyzstan and their kinsmen in Kazakhstan is the archival data, statistical, historical, and field sources, which provide a systematic overview of the largely unstudied pages of the history of the Kazakh diaspora.
\end{abstract}

Keywords: Kazakh diaspora, Kyrgyzstan, migration history, oralman ${ }^{1}$ repatriates, population size, settlement 


\section{INTRODUCTION}

The diaspora has played a significant role in the foreign policy of Kazakhstan, which aims at stressing the continuity of the unity that is said to exist among all the Kazakh people. The Kazakhs living abroad ${ }^{2}$ are an essential target for the republic's foreign policy, as far as the relations with neighboring republics are concerned. They often keep strong ties with their historical motherland. Different historical, cultural, political, and economic reasons, which made them leave the homeland, have determined their current residential status. This status also depends on their country of residence's foreign policy and relations with Kazakhstan. Since its foundation in 1991, Kazakhstan has been trying to position itself in the international arena as a democracy-oriented state respected by the global community. Consequently, this vision determines how Kazakhstan chooses the ways to either support or neglect interests of kinsmen abroad. Fierce disputes about what constitutes the Kazakh diaspora abroad characterized the academic debate in Kazakhstan in the 1990s and early 2000s (Mendikulova 1997). Finally, Kazakhstan's scholars have adopted something that approaches a consolidated definition of diaspora close to Gabriel Sheffer's definition: "Modern diasporas are ethnic minority groups of migrant origins residing and acting in host countries but maintaining strong sentimental and material links with their countries of origin - their homelands" (Sheffer 1986: 3).

Unfortunately, the current level of historical research covering the problems of the formation of the Kazakh diaspora and the main periods of its history is far from satisfactory (Mendikulova 2006; Koblandin 2008; Tatimov 1992), although there is an obvious need for such research. Among the most pressing challenges of modern studies is the problem of the formation of the Kazakh diaspora in Central Asia, including the neighboring Kyrgyzstan. This topic did not get enough attention in the national and foreign historiography due to various reasons (Kalshabayeva 2014). During the Soviet period, this research topic was an implicit taboo. On the other hand, there was an upsurge of scientific interest in ethnic problems, particularly diaspora studies, after the postSoviet republics (including Kazakhstan) gained their sovereignty, leaving the theoretical basis of such research in chaos.

Before the country gained independence, the Kazakhs living abroad had not been studied as a diaspora in a foreign environment. However, Russian and foreign researches conducted in the eighteenth and nineteenth centuries had come up with significant information that covered the issue of Kazakh settlements since ancient times. The famous Russian traveler Peter Pallas (1778) acquainted his readers with the population and ethnic composition of Kazakh settlements in the Turkestan region. P. Pashino (1868) continued to explore the southern region and focused in particular on the Tashkent region: his papers 
contained data about the Chirchik Kazakhs, their households, anthropological type, etc., while N. Grodekov's (1889) works mainly presented the Kazakhs of the Tashkent uyezd (district) and their life and culture. R. Karutts (1910) described Kazakh life and material culture in Mangistau and Turkmenistan. V. Masalsky (1913), on the contrary, focused more on the economic structure and material life and handicrafts of the Kazakh tribes that populated the Turkestan region. Russian travelers and scholars were primarily interested in defining new territories, the native population's culture and their economy to later serve as a repository of scientific data.

The work done during the Soviet period differs from the previous approaches adopted by Russian scientists, which constituted collecting data for exploring historical roots, reasons of migration, and factors affecting the direction and intensity of Kazakhs' movements into neighboring lands. Soviet ethnography had faithfully served the state's interests, especially during the delimitation of the borders of the Asian republics in the 1920s-1930s. The Academy of Sciences of the USSR organized numerous expeditions that continued collecting field materials covering these issues (Materials 1927). Some information was gathered during the expeditions dedicated to the zoning of Uzbekistan (Materials 1926). Later on, Soviet ethnologists continued researching Kazakh migration and settlement problems in Central Asian republics (Arkhipov 1930), touching also upon the most sensitive questions of co-existence of different ethnic groups in the lower reaches of the Syr Daria River basin, including Kazakh tribes inhabiting Karakalpakstan (Shalekenov 1966). Kazakh people had been living close to Kyrgyz tribes in the Zhetysu Oblast long before the border delineation between the Central Asian Soviet republics started (All Central Asia 1926). The most important information covering Kazakh people's life in Kyrgyzstan can be found in the "Review of the Semirechye Region" (Yearbook 1924), in Masalsky's work "Turkestan Region" (Masalsky 1913), and in the materials of the statistical committee of the Turkestan region.

In the post-Soviet period, M. Sartbayev (2009), K. Koblandin (2012), K. Baltabayeva (2011), B. Kalshabayeva (2011), and other local scholars researched this topic. Sartbayev mainly investigated the historical reasons for the formation of the Kazakh diaspora in Kyrgyzstan, while Koblandin focused on its ethno-demographic composition. Baltabayeva and Kalshabayeva analyzed the census data that had been collected in Kyrgyzstan since 1991, when the republics declared their independence. Kalshabayeva devoted a special chapter in her monograph on the issues of Kazakh settlements, the size of the Kazakh population and its dynamics, along with the ethnic history of the Kazakh tribes.

The migration of the Kazakhs from their historical motherland was caused by many historical events and catastrophes. The most significant movement of the Kazakh tribes into neighboring territories took place due to the hardships of the Dzungar-Kazakh wars, particularly in the early eighteenth century. Kazakh 
people still remember the 'Years of Great Calamities' (1723-1727) which brought with them famine, terrible sufferings, and destruction of their traditional economic life. A split between the zhuses (hords) of the Kazakh Khanate was accompanied by a catastrophic dissent among their political elite about how to politically engage the neighboring states. The political situation was still worsened by the Kazakh, Bukhara, and Kyrgyz inconsistency in actions, and a sudden attack from the Oirat (Dzungar) side ended with a catastrophic defeat of some Kazakh tribes. Later on it led to the seizure of the settled oases along the Syr Darya River, which forced the Kazakhs to leave their lands. Further migrations followed due to the colonization policy of the tsarist government and the settlement movement of the Russian peasantry from the central part of the Russian Empire. Kazakh participation in the 1916 uprising was brutally suppressed by the Russian authorities and was followed by a next wave of migrations. In the Soviet period, the last substantial migration wave occurred due to the great famine of 1932-1933 (Kalshabayeva 2014).

\section{THE RESEARCH OBJECT}

Our research object is the history of the formation and the ethnographic peculiarities of the Kazakh diaspora in Kyrgyzstan. Since Kazakhstan declared its independence in 1991, the country's political leadership, namely the first president Nursultan Nazarbayev (1991-2019), persistently worked to establish and strengthen ties with Kazakh kinsmen living abroad (Mendikulova 2006: 80). The situation of Kazakh people in Kyrgyzstan was among the urgent problems discussed in the republic's media. In 1999, statistical data of the Kyrgyz Republic showed that the number of Kazakhs was 42,657 (Statistical Data 2001), while by 2009 this number had decreased to 33,200 (Kalshabayeva 2011). Here we try to analyze the main reasons for the change in the number of Kazakh population in Kyrgyzstan. Some scholars insist that the main characteristic of Kazakhs is their ability to adapt successfully to any new environment (Svanberg 1989), which gave us a reason to focus on the causes of variation data. Meanwhile, the Kazakhs are strongly inclined towards keeping their traditional foundations such as tribal belongings, customs, and language. Svanberg, when characterizing the Kazakh diaspora in Turkey, stresses: "Strong and self-conscious Kazakh group identity continues to exist even under changing conditions of new environment with everyday new rituals, usage of new technologies, alien economic system, new pace of work and gustatory habits" (Svanberg 1989: 211). 


\section{MATERIALS AND METHODS}

The authors used a number of archive findings, for instance, materials of collections 847, 21, and 105 from the Central State Archive of the Kyrgyzstan Republic, which includes valuable information about the history of migration and the settlements of Kazakh people in Kyrgyzstan. For instance, collection 847 of the Special Commission for Land Management contains materials on the forced migration that led Kazakhs ${ }^{3}$ to leave their lands, and measures taken by the government to return them to their former place of residence. Having analyzed these documents, the authors faced problems such as the diversity of causes of Kazakh migration from Kazakhstan that had started from the second half of the nineteenth century and lasted until the end of the Great Famine of 1932-1933. The main reasons that drove Kazakhs to leave their lands were the tsarist state's policy since the colonization of the Kazakh territory by the Russian Empire, which was accompanied by rangeland seizures. Later, the national liberation movement of 1916 was brutally suppressed by the Russian colonial authorities, which led to the outflow of 100,000 Kazakhs into China. However, some Kazakhs stayed in Kyrgyzstan to escape the hostility of the Chinese side. The Russian tsarist authorities, namely the general-governor of the Turkestan region, A.N. Kuropatkin, claimed that the national liberation movement of 1916 had been supported by the Chinese, which led to bitter disputes between Russians and the Chinese. Finally, the Russian administration, due to numerous petitions of Russian and Kazakh politicians and intelligentsia, was asked to declare an amnesty for all Kazakhs and Kyrgyz to give them an opportunity to return to the Semirechye (Zhetysu) region. The second reason that drove Kazakh migration out of the republic was the Soviet policy of collectivization, which finally led to famine in the early 1930s. It was mainly state policy that affected Kazakh migration and there were various reasons why Kazakhs, instead of heading towards neighboring China, preferred to stay in Kyrgyzstan.

The Central State Archive of the Republic of Uzbekistan also contains ubiquitous materials concerning the Kazakh "migration" that had been caused by the delineation of the borders between the Central Asian republics in the 1920s and 1930s and the subsequent destiny of Kazakh settlements. Some of the Kazakh families preferred to move to Kazakhstan while mostly they continued their traditional life in the newly established Kyrgyz Soviet Republic. Collection p-1 (State Archive of Uzbekistan) contains materials on controversial issues of rangelands usage. In 1926 an order of pasture use was adopted, namely for grazing dzhaylyau Susamyr ${ }^{4}$ in the Kyrgyz Republic, which defined that this pasture in the Kirghiz Autonomous Region was provided for the nomadic population of the Kazakh Republic to be used for summer grazing in 1926 and as summer pastures on the following grounds: a) People must roam to pasture 
Susamyr and run the cattle along the cattle roads Kok-Kiya, Kupre, Chabyr, and Utmek and all the cattle heading from the Kazakh Republic to the Kyrgyz Autonomous Region must have the appropriate veterinary certificate from veterinarian stations in the residence points. Cattle grazing on pasture Susamyr is not permitted without these certificates; b) The cattle owned by the citizens of the Kazakh Republic, passing along the road defined in paragraph 1, across state-owned lands and forest cottages are exempt from fees for grazing and cattle driving under the condition that the cattle stay on the road for no more than two weeks. In the case of running cattle across pasture Susamyr or other roads, but not the roads and passes specified in paragraph 1 , section a, livestock owners pay 20 kopecks per head of the horned cattle, and 10 kopecks per head of the small cattle to field or forest guards (CSA RU, F.r-1. op.1. d. 707. pp. 94-95).

The methodological arsenal of the research includes as scientific methods interviews and analysis of questionnaires of more than 60 informants living nearby Bishkek ${ }^{5}$ and surrounding regions. However, in this paper information of 12 interviews and questionnaires was used. This choice was determined by the compact character of the Kazakh settlements in this part of the Kyrgyz Republic, such as the villages Manas, Razdolnoye, Altybarak, and others. All respondents agreed to be interviewed and voluntarily answered the questionnaires. The selection of informants was based on the "snow ball" principle in places of compact settlements of Kazakhs in Kyrgyzstan. These materials were collected during fieldwork in Kyrgyzstan in 2000-2001 and in 2009-2011, in the neighboring Bishkek districts - Alameddin, Sokuluk, Talas, Shu, and others. All materials were classified according to tribal composition, economic activities, family customs and traditions, and the compact character of the Kazakh settlements. The authors also used complex historical methods such as the principle of historicism, analytical-comparative methods, and comparative-historical methods. The historicism principle was used to identify the main stages of the formation of the Kazakh diaspora in Kyrgyzstan beginning in the nineteenth century. Ethnographic peculiarities of the Kazakh diaspora were researched on the basis of analytical-comparative methods to highlight the differences between the local population and Kazakh settlers. The following research methods were used: ethnographic field research, interdisciplinary research along with the comprehensive analysis of population, resettlement and repatriation of oralmans to their historic homeland. Therefore, the historical-comparative analysis focuses on the problems of population dynamics of Kazakhs and the identification of social and political factors that caused population growth or decline. The correlation analysis is applied to the classification and systematization to select main political and socio-economic factors contributing to the Kazakh repatriation from Kyrgyzstan. 
The main research problem that initiated this study is the question about how far the success of representatives of the non-titular Kazakh ethnic group in Kyrgyzstan contributed to curbing their desire to return to their homeland. On the way towards social adaptation in the new country there are cultural and psychological barriers to become a full-fledged citizen of the country while being able to keep another ethnic identification. J. Berry (2003) suggested defining the social-cultural adaptation of migrants in correlation with the following factors: 1 ) cultural proximity between home country and new environment; 2) the number of contacts between newcomers and local population; 3) what activity migrants are involved in in the receiving country; and 4) the ability to speak the languages of the receiving country. Kazakhs' adaptation had run comparatively smoothly due to significant similarities of culture and economic life of the Kyrgyz and Kazakh people. Also, Kazakh people were living and continue to live in compact settlements near Bishkek, which has helped them to maintain their traditional economy (cattle-breeding system) and a strong ethnic identity.

\section{ON THE PROBLEM OF THE KAZAKH DIASPORA FORMATION IN KYRGYZSTAN}

The historical events of the 1916 national-liberation movement became one of the main reasons that promoted the formation of the Kazakh diaspora in Kyrgyzstan. The documents found in the Central State Archive contained materials to prove this hypothesis.

The 1916 events in the former Zhetysuyskaya Oblast ${ }^{6}$ or the so-called Kyrgyz revolt ended with an outflow of large groups of the Kyrgyz abroad, to neighboring China. Almost all people living in the Karakolsky uyezd ${ }^{7}$ (parish) and in five volosts of the Narynsky uyezd, i.e., more than half of the population left their native lands. The big Sarybagyz volost, which is in Pishpek uyezd, and most of the inhabitants of Shamsin and Tykaevskaya, did the same as did the Kyrgyz people from Alma-Ata, Lepsinsk, and Kapal. (CSA RK, F.847. op.1. d. 27. L.136-136 obr.)

Unfortunately, the exact number of refugees is still impossible to determine. However, we estimate this number as approximately 100,000 people. All of them fled to western China, mainly to two districts: Ili with its center in Kuldzha and Kashgar-Uch Turfan with such urban centers as Uch Turfan and Aksy. A Chinese state representative, A. Saltanaev, reported to China the following estimates of Kazakh refugees to the Ili district: "Up to 300 families from Lepsinsk, about 150 families from Kapal, 400 families from Zharkent, and 210 
families from Karakol, while Pishpek accounted for eight families. In total there are 1068 families" (CSA RK, F.847. op.1. d. 27. L.136-136 obr.).

Due to the terror of the Reds and partisans fighting for the Soviet power in 1917-1918, the next waves of Kazakh refugees followed the previous movement to the Chinese territories. Their fear was rooted in the events of 1916, when rich and prosperous Kazakhs were terrified by the news about the possible confiscation of their cattle and lands.

The Chinese authorities were certainly not happy about these unexpected movements and used all the possible means to force the Kazakhs to migrate either back to Kazakhstan or to the territories of the neighboring countries. As archival materials show, they oppressed the Kazakh newcomers, and humiliated them to prevent their settlement on the Chinese land. State commissioner Belen Sanayev, in his report addressed to the Chair of the Kyrgyz Executive Committee ${ }^{9}$ Zelensky, states:

The situation with the Kazakh refugees is awful. They were unable to get accustomed to the new environment. The pressure of negative factors forced them to sell the Kyrgyz and Kara-Kyrgyz into slavery. Many Kazakh women got married to the Chinese by mistake because they confused them with Muslim Dungans. Later, when they discovered their mistake, some of them complained to the Chinese authorities. In response, the Chinese administration ordered to cut off their tongues. Moreover, women who tried to leave their Chinese families were beaten or executed (murdered) by state authorities. There were cases where Chinese spouses, after marrying Kazakh women, later got married to their daughters when they reached the age of 12. Many desperate women committed suicide by rushing into rivers. (CSA RK, F.21. op.3. d. 105. L. 6-7 obr.)

The Soviet government, after receiving a number of reports from the local authorities of the Kazakh Republic, decided to act decisively and start the process of repatriating refugees from China. During the spring of 1918, the first migrants from China came back to their native lands. The process of repatriation was difficult and long; it lasted until 1921/22 when the Soviets launched their land reform. Because of the confiscation of property, many Kazakhs were afraid of returning and preferred to stay in the Kyrgyz territories. The fears of the Kazakh people can be explained by their experience of the punitive colonial policy of Russia, as after the revolt of 1916, the general-governor of the Turkestan region, Kuropatkin, had initiated a wave of confiscation of the Kazakhs' lands. The Provisional Government, during 1917, was unable to solve this problem and later, during the civil war, the complaints of Kazakhs were left unanswered. Field materials collected by one author during her expeditions confirmed the validity of these considerations. For instance, one of the informants, Kasen 
Abdyganiev, told stories about how his ancestors had settled in Kyrgyzstan after leaving China. Kyrgyz manaps ${ }^{10}$ provided significant assistance for Kazakh refugees: they received cattle and pastures in Kyrgyz lands (Kaliyev Bugibay, Field materials 2000).

Two trends affected the Kazakh migration dynamics in the early 1920s: the influx of the Russian population and the return of Kazakh-Kyrgyz people who had escaped to China after 1916. During four months in 1921, the total number of Kazakh repatriates reached 517 while in Kyrgyzstan the number reached 307. As chair of the Zhetysu district executive committee, Kudebayev, said, 'during the period June-December 1925, 67 families (372 people) were evacuated to Semirechye, and the number of Kyrgyz families is estimated to be 65, i.e., 363 people (Kalshabayeva \& Seisenbayeva 2013). Between March 23 and June 1, four Kazakh families (eight people) arrived in Pishpek Okrug, six Kazakhs arrived in the Almaty uyezd, while Karakol received five Kazakhs (CSA RK, F.847, op.1, d. 27, pp. 128-129).

The Kazakh diaspora in Kyrgyzstan added new migrants when Kazakhs of the Argyn tribe decided to migrate in search of new pastures. The issue of delineation of the borders of the Central Asian republics also brought up discussions about the territories of the ethnic groups. Later, these measures led to Kazakh mass migration into Kyrgyz-populated lands. Demarcation of the borders also raised issues related to pasture (dzhaylyau) assignments. Among the disputed areas were such pastures as "Tracts Susamyr", "Han Dzhaylyau", and "Karkara". ${ }^{11}$ For instance, shortly before the revolution of 1917, the Susamyr region, located in the northern part of the Kyrgyz Autonomous Region, was jointly used by Kazakh nomads and Kyrgyz cattle breeders from the Aulie-Ata district, which later became part of Kazakhstan.

The Susamyr pasture became the object of heated debates due to its location. Those Kazakhs who were interested in using Susamyr pastures had to drive cattle from their winter camps hundreds of miles through two volosts ${ }^{12}$ and over two high ridges (the Alexander and Talas ridges). This only paid off for the cattlemen who had thousands of cattle in their herds, whereas for small herders driving cattle over long distances was unprofitable. Moreover, by the decision of the Central Executive Committee from May 3, 1927, dzhaylyau Susamyr and other pastures went into the possession of the Kyrgyz region. This fact also led to the growth of the Kazakh diaspora in Kyrgyzstan.

Demarcation of the territory between Kazakhstan and Kyrgyzstan also caused disputes concerning the Kazakhs living in the area of Atbashi of the Pishpek uyezd. Here is the translation of the document signed by Argyn Kazakhs to confirm their right to possess this land, addressed to the Land Management Committee of the Kyrgyz ASSR: 
The Land Code states that land should belong to those who cultivate it and live on it. We, the Argyn-Kazakhs, from Akmola and Karkarala uyezds, arrived in the Pishpek uyezd forty years ago as workers/laborers and shepherds. We have settled in Atbashi and since this time we have been living here. This fact is confirmed by the surveyor's act from the Frunze land surveying group on June 4, 1926. Copies are attached here. (CSA RK. F.21.op. 1. S.5. L. 61.63)

They continued with complaints that they had had to wait until 1928 to solve all the disputes over land plots.

By the Decree of the Presidium of the Central Executive Committee, issued on July 23, 1928, the border between Kyrgyzstan and Kazakhstan was established. It determined "the boundary along the Chu River as follows: from the western part of the Kamyshanovsky village crossing through its territory, ${ }^{13}$ then down to the Chu River and upstream the river to the village of Argyn, bending it from the south ${ }^{14}$ and then upstream the Chu River, etc." (CSA RU, F. r-1, op.1, d. 707, pp. 95-96).

Such demarcation boundaries of the village Argyn cut its inhabitants off from Kazakhstan.

The inhabitants of Argyn, numbering 42 households, ${ }^{15}$ made complaints to the authorities with a request to settle them in another part of Kyrgyzstan and to grant them citizenship (CSA PK, F. 21 op. 3, d. 26 L. 39-40). According to the archival documents, this request was discussed at the meeting of the Central Administrative Commission (NKVD of the Kazak ASSR) on November 16, 1928. The Commission adopted a resolution to satisfy Argyn-Kazakhs' request, in order to provide economic benefits for the dwellers of the village (water was delivered from the side of the Kyrgyz Republic) and due to the strong desire of Kazakhs to change their citizenship (CSA RU, F. r-1, op.1, d. 707, pp. 95-96).

In the period from 1926 to 1939, the population of Kyrgyzstan increased by 456,500 and was estimated to be $1,458,200$. The influx of the population to the republic resulted in an average annual increase of 3.9 percent. This figure was three times higher than data for the pre-revolutionary period shows. The average annual increase of the Kyrgyz population was 1 percent, while the growth of the other ethnic groups was estimated as follows: Russians 13.3 percent, Uzbeks 3.1 percent, Ukrainians 9.5 percent, Germans 14.4 percent, Tatars 25.6 percent, Kazakhs 104.5 percent, and Tajiks 6.7 percent (Zhelokhovtsev 1989). Russian Germans also lived on the territory of Kyrgyzstan. The number of Kazakhs in Kyrgyzstan on December 17, 1926, was estimated to be 1,749 (0.2 percent) while on January 17, 1939, the number of Kazakhs reached 23,925 (1.7 percent) (CSA RK, F. 21, op. 5, E. 6, p. 109).

The next large flow of migrants from Kazakhstan and Siberia entered the Kyrgyz lands in 1932-1933, when people were severely suffering from the 
consequences of collectivization, such as famine, crop failure, food shortages, and other difficulties. Migration processes significantly changed the ethnic composition of the republic. By 1939, the indigenous population of Kyrgyzstan experienced a relative decrease to 51.7 percent, while other ethnic groups relatively increased. For instance, the Russian population increased to 20.8 percent, and the Kazakh population to 1.6 percent (CSA RK, F. 105, op. 31, D. 324, p. 47).

An increase in the number of Kazakhs in Kyrgyzstan was also caused by labor migration in search for better incomes in the 1960s and 1970s. During these two decades, due to the circumstances mentioned above, 21,263 people migrated from Kazakhstan to Kyrgyzstan, among them 486 Kazakhs who migrated to Issyk-Kul, 108 to Naryn, and 2,439 to Osh. The composition of migrants from Kazakhstan by regions of origin is as follows: 1,163 people migrated from the Aktobe region, 852 from Almaty city, 1,345 from the wider Almaty region, and 1,330 from eastern Kazakhstan. However, the largest number of migrants came from the territory of Dzhambul Oblast - 5,469 people ${ }^{16}$ (CSA RK, F. 21, op. 1 , S. 5, p. 61.63).

The process of formation of the Kazakh diaspora in Kyrgyzstan covered a long period in history. Each stage of this process was characterized by particular driving factors. The authors have made an attempt to determine the different periods in the history of the formation of the Kazakh diaspora and the driving factors and reasons for migration. However, it was an extremely complex, multifaceted process that formed the modern Kazakh diaspora in Kyrgyzstan.

\section{ABOUT THE HISTORY OF SETTLEMENT AND POPULATION DYNAMICS OF KAZAKHS IN KYRGYZSTAN}

Under the colonial administration of tsarist Russia, Aulie-Ata, Bishpek, and other uyezds were part of Zhetysuyskaya ${ }^{17}$ Oblast. This was for the convenience of the territorial-administrative governance. The Russian administration never had a particular ethnic demarcation of these territories in mind. Traditionally, the Kazakhs of Kyrgyzstan had been living on the territory between the Balkhash and Issyk-Kul lakes. For instance, the statistical yearbook specified that in the Pishpek uyezd, Prigorodnaya volost, 556 households had a total of 2,477 people. Kazakh households were divided between different uyezds in the following way: four households in Naryn and 48 households in Pishpek (Yearbook 1924: 146-147).

The first national census was conducted by the Russian authorities in $1897^{18}$ to determine the size, ethnic composition, and employment of the Kazakh and Kyrgyz population. In 1897 the territories of modern Kyrgyzstan were included in Semirechenskaya Oblast of Turkestan General Governorship. Comparison 
of the data provided by the 1897 census and a second census conducted in 1913 show a significant growth of the Kazakh population in Kyrgyzstan: the respective figures were 663,000 and 863,900 (Zhelokhovtsev 1989).

In the period from 1871 to 1896 , the Russian administration continued to change the boundaries of Zhetysuyskaya Oblast, which consequently touched the area of the Pishpek uyezd. The census results indicated that Kazakh people were also living in this uyezd. Initially, the lands of the Kazakh population were joined to the Vernyui uyezd and later on their territories were again transformed into the Pishpek (Tokmak) uyezd (Krongardt 1989).

Territorial changes became the main factor that had naturally led to the formation of the Kazakh diaspora in Kyrgyzstan. Kazakhs preferred to stay in that area and continue to populate it. The fact that Kazakhs have lived in Kyrgyzstan, including Naryn Oblast, for a long period, is confirmed by numerous archival documents. Thus, one of the archival documents describes how Kazakhs reacted to the census conducted by the Russian colonial administration:

On May 5, 1909, while the census was conducted, the Kyrgyz ${ }^{19}$ from the Naryn Volost attacked A. Lutin, and he was left badly injured. Although the Kyrgyz do not present any special risk, their actions can cause some damage and undermine the authority of the Russian administration. Due to this consideration they should be sent to Akmola. (CSA RU, F.1. op.4. d. p. 1390. 2.9.)

The Kazakh population's living conditions and their settlements in the IssykKul region are described in the Central State Archive of the Republic of Kyrgyzstan (F. 21, op. 3, d. 105, p.6.) as follows: "|The Issyk-Kul basin of Aksu was a convenient area for Kazakh settlements, whereas Zauka was not of particular interest, except as an object of agriculture. Kazakhs mostly migrated between Aksu and Topay."

Unfortunately, before the 1917 revolution, information about the number of Kazakhs and Kyrgyz was reported under the common term "Kyrgyz", which makes it difficult to determine the exact number of Kazakhs. These ambiguities in the calculation of the population can be seen while analyzing several archival documents. The document dated 1927 noted that in 1926, 14,324 Kazakhs lived on the territory of Kyrgyzstan, whereas in May 1927 only 1,766 Kazakhs lived there (CSA RK, F. 21, op. 3, d. 105, p. 6). Such discrepancies can be explained by migrations and demarcation of rangelands that took place in the republic.

All censuses conducted before 1926 contained information about shalaKazakhs ${ }^{20}$. These were mainly the descendants of mixed marriages, often between Kazakhs and Sarts or Kazakhs and representatives of other ethnic groups. About 469 shala-Kazakhs had been living in Aulie-Ata before 1926. Their descendants, who now live in Kyrgyzstan, declare themselves as Kyrgyz 
and those who live in Kazakhstan as Kazakhs. However, the collected field data shows that by anthropological, linguistic and cultural features they merge with Kazakhs. Field studies confirm that some representatives of shala-Kazakhs called themselves Kazakh by origin. These factors also contributed to the increase of the Kazakh diaspora.

The ethnic structure of the Kyrgyz Autonomous Region in 1926 was as follows: 4.6 percent of Kazakhs, 44.8 percent of Kyrgyz, 4.2 percent of Uzbeks and 41.4 percent of Russians. In the Karakol-Naryn region, before 1917 the share of Kazakhs was estimated to be 1.8 percent, that of Kyrgyz 71.8 percent, and that of Uzbeks 2.3 percent (Masalsky 1913: 650-651).

In 1926, the population of the Kyrgyz ASSR exceeded its pre-revolutionary level by 13,700 people and reached 1,001,600 (Materials 1926). Different reasons led to the multi-ethnic composition of the population in pre-revolutionary Kyrgyzstan. Thus, Kyrgyz republics had become a new native country for many ethnic groups along with the indigenous population. Summarizing the data provided above, we may conclude that the dynamics of the Kazakh diaspora's growth throughout the period of its formation depended on various factors that affected its relatively small size in comparison to other regions of Central Asia.

\section{KAZAKH REPATRIATES FROM KYRGYZSTAN}

Since Kazakhstan declared its sovereignty, the revival of oralman-repatriates' movement from Central Asia back to their homeland might be observed. The Kazakh diaspora in Kyrgyzstan, as compared with the representatives of other republics, lives relatively well despite the economic difficulties experienced by the country. This is one of the reasons for their slow return to Kazakhstan. Besides, many Kazakhs living in Kyrgyzstan are descendants of refugees, who had suffered from political repressions and economic hardships such as the 1932-1933 famine. Some of the western scholars (Schatz 2004; Dave 2010) often considered the problem of oralmans in the context of the contemporary policy of Kazakhstan, without embedding it in broad migration processes. Edward Schatz mentioned oralmans in his work not through the lenses of migrants but due to their presupposed role in the political struggle for power in Kazakhstan (Schatz 2004). He also referred to B. Dave's work (2010) where the analysis of the repatriates' problems was conducted exclusively in terms of political approach.

In general, Kazakhs in Kyrgyzstan live better than their peers in other countries. However, young Kazakhs have a strong desire to return to their homeland. Statistical data for the period 1989-1998 indicates the return of 2,093 Kazakhs to Kazakhstan (Kalshabayeva 2011). The data shows that 1,224 people had moved to the Dzhambul region, and later on 428 of them moved to towns, and 
796 - to the countryside. The Almaty region attracted fewer repatriates -390 people, whereas 133 of them preferred to settle in urban areas and 257 chose rural districts. The region of southern Kazakhstan received 101 people; 58 of them migrated to urban centers and 43 became rural residents. The Karaganda region was a final destination for 105 repatriates: 89 of them stayed in towns and 16 preferred the countryside. The strength of the new settlers to the region of eastern Kazakhstan is estimated as 90 people, with 69 as urban citizens and 21 as countrymen. Barely few dozens of repatriates have settled in other areas of Kazakhstan (Census 2000: 77-78).

\section{ETHNOGRAPHIC PECULIARITIES OF KYRGYZSTAN KAZAKHS}

Though the customs and traditions of the Middle Asian and Kazakh peoples in the nineteenth century differed from each other, the gist was the same. All these nations shared common origin, history, and language, as for centuries they had been living close to each other. Thus, the similarities in historical development and geographical proximity had shaped some common cultural elements. However, one might observe that there were enough characteristics to demonstrate their cultural and anthropological differences.

In the 1960s-1980s, bride kidnapping was widespread in the regions that were researched by the authors. However, in Kazakhstan we rarely encountered this phenomenon while in Kyrgyzstan we could observe a considerably greater number of bride kidnappings. Unfortunately, among the local Kyrgyz population the old customs and traditions caused real economic difficulties to some in the lower strata of society. In order to reduce their negative impact, bride kidnapping (with the consent of a bride) began to be widely practiced. Surprisingly enough, the Kazakh diaspora in Kyrgyzstan started to follow this practice (Abdibaev Kasen, Field materials 2001). Some of the informants said that the rapid growth of bride kidnapping among Kazakhs had been due in part to the pressure of the Kyrgyz environment (Kalshabayeva 2014: 134-135).

One of the main differences in the traditions related to Kazakhs' marriages in Kyrgyzstan as compared to those in their home country was 'kuyeu tabak'21 of a groom for the bride's sister-in-law ${ }^{22}$. He put 30-100 meters of a very expensive fabric onto it. Until the 1970s, the fabric was tied up around her (sister-in-law's) waist and other women (sisters-in-law) ${ }^{23}$ would untie it and pass around. Additionally, when coming to the bride's house, the groom should have a bar of soap, some perfume, a kerchief or some jewelry in his pocket for the younger sisters of the bride. These traditions are still practiced in all Kazakh-populated regions of Kyrgyzstan (Dastagul Omarovna Mukhanbetova, Field materials 2011). 
Many guests, including the bride's relatives and neighbors, are invited to $k y z$ $u z a t u^{24}$ party. Each of the party attenders contributes to the bride's dowry. They give her various household goods, utensils, and clothing, which are important for the young couple. In earlier times, Kazakhs used to send the bride and her friends to visit the households in the village to invite guests to kyz uzatu, to give her a chance to say goodbye to the relatives.

The Kazakh bride in Kyrgyzstan usually visits her relatives before the wedding party together with her two sisters-in-law. If the bride has no brothers she can be accompanied by her cousins' wives. Her relatives gladly welcome her and give their gifts. Before the bride's sendoff, her parents allow her to take a sightseeing tour of the neighborhood. The whole trip might be videoed and finished with entertaining programs to raise the bride's spirit.

Kazakhs' recitals dedicated to various national holidays and special events are well known in the region. For example, 'zhar-zhar'25 and 'synsyma' and 'synsu' ${ }^{26}$ are still performed by the Kazakh people. Synsu is usually devoted to the girls who were forced into marriage. Synsyma and zhar-zhar were rarely practiced among the Kazakhs in Kyrgyzstan. Usually these recitals were recorded by old people and performed by young Kazakhs just for fun. Today we can see that young people have little interest in such a tradition as synsyma. Here is a synsyma that was recorded by 92-year-old Maken Abisheva from Bishkek:

How hard it is to leave you

My sweet home, my dear friends...

I am more depressed today

Thinking of the forthcoming day

My dear sister, little star,

I will be with you

Wherever you are!

(Abisheva Maken, Field materials 2001)

Traditionally all the community members are invited to the ritual called betashar ${ }^{27}$. Though betashar is an extremely popular ceremony among Kazakhs in Kyrgyzstan, the Kyrgyz tradition of betashar has some differences. The bride is supposed to bow to all the people whose names were mentioned at the opening ceremony. When betashar is over, a man ${ }^{28}$ unveils the bride's face and usually gets a payment for this service (Field materials 2009). If a bride is kidnapped, two smart people from the groom's side are sent to her parents to inform them and to apologize for the young people's behavior. Parents traditionally receive some special gifts called oli'tiri" ${ }^{29}$. A.T. Toleubayev (1991: 214) points out: "Since oli-tiri is dedicated to the bride's deceased relatives, it is usually served as a dish to the aksakals of the village". Argynbayev (1996: 288) also mentioned this tradition in his work. 
Oli-tiri is a widely spread practice of Kazakhs in Kyrgyzstan but they have added some new elements to this tradition. Apart from the sheep, they also give a golden handshake to the bride's parents. ${ }^{30}$ Informant Bugybai Kaliev indicated that the amount of money paid by Argyn-Kazakhs was more than the amount among the Uisun clan. Besides, they also add some sweets and alcohol drinks to oli-tiri; this is the main difference between Kazakhs in Kazakhstan and in Kyrgyzstan. Probably the latter can be explained by the strict alcohol prohibition in Muslim-dominated southern Kazakhstan as compared to the Kyrgyz' indifference towards some important institutions of Islam. The Kyrgyz people call it kuldyk urdyk $k^{31}$.

Nowadays every second marriage in Kyrgyzstan is international/interethnic. The quantity of mixed marriages is relatively high in this country especially among the Kyrgyz and Kazakhs. Kyrgyz researcher Kochkunov commented on the ratio of interethnic marriages: "We have examined 34 mixed marriage families. 28 of them live in Orgochor sovkhoz. 14 of them are Kazakh-Kyrgyz, 3 of them are Uzbek-Kyrgyz, and 2 of them are Kyrgyz-Kalmak' (Zhelokhovtsev 2000: 167). This passage demonstrates that Kazakhs in Kyrgyzstan are more likely to marry representatives of other ethnoses than Kazakhs in Kazakhstan.

When we made a tour in the countryside, nearly every Kazakh family had a daughter-in-law or a son-in-law of Kyrgyz nationality. If this tendency continues, the future generations of our fellow citizens in Kyrgyzstan will become descendants of mixed marriages after a certain period.

Most Kazakh families living in the regions under study still maintain a strong patriarchal society, which is typical for the Kazakh lifestyle. Until the middle of the twentieth century many national wedding traditions and ceremonies had been strongly kept within the region. However, as time passed, these ceremonies - particularly the ones related to weddings - became greatly influenced by the local traditions and customs.

The cradle played and still plays a great role in the upbringing of Muslim people. Kazakhs called it besik, and the first time a baby is put into the cradle was called besikke salu ${ }^{32}$. It was a big event in the life of a child and the parents. I.S. Kolbasenko noted: "In the Tokmak uyezd it was called 'beshik' in Kirgiz" (Kolbasenko 1889). One of the advantages of the Kazakh besik was its comfort; it did not cause any trouble during the journeys; it was very convenient to carry it whenever people moved. In fact, children of nomadic people, particularly Kazakhs, did not suffer from any skin diseases thanks to the besik. Surprisingly, nowadays, the Kazakhs living in Kyrgyzstan do not use the besik at all.

Since the Kazakhs in Kyrgyzstan do not use the besik for a child, they are limited to gift-giving (Field materials 2007). In Kyrgyzstan Kazakhs are illinformed about this tradition. They simply give a gift to a woman who puts 
the baby into the besik. The Kyrgyz people use nine things to cover the besik, while the Tajiks use seven (Bizhanova 2001: 19). When the baby is placed in the besik, an old woman gives it her blessings, wishes good luck to the baby. Before that the young mother, while holding the besik, bows to the guests to express her gratitude to God for having a sweet baby.

One Kyrgyz tradition, which is shared by the Kazakhs in Kyrgyzstan, is the child's visit to the mother's parents to cut the child's hair. It happens when the child reaches the age of three. The grandparents give the child a big present. Kazakhs also have a tradition of giving one of the livestock to a child who visits them for the first time (Bulekbay Tyrybolsynuly Madibekov, Field materials 2011). It is called basire. Some parents leave hair on the back of the child's head. It is called aidar shash. They cut it off only when the child is circumcised.

One of the ceremonies that takes place in the early age of a child is tusau keser. The feet of a child, who makes the first steps, are tied up with a motley string. A small bell is attached to the string. Then a person who is chosen by the child's parents cuts off the string. The string is believed to protect the child from an evil eye, while the bell will make him popular (Field materials 2008). Recently Kazakhs have used some variations of this tradition in Kyrgyzstan. The child's parents organize a 'marathon' ${ }^{33}$ for a group of children, and the one who finishes first will be honored with cutting the string off. Bugybai Kaliev and Marfu Balabekova, residents of the Manas village (Marfu Balabekova, Field materials 2008), say that this tradition originates from the Kyrgyz people. Earlier on, Kazakhs used sheep's intestines instead of a string. It was supposed to bring success to the child. In some regions of Karakalpakstan, koz monshak ${ }^{34}$ replace the string, while in Kyrgyzstan a red ribbon is used instead to make the child walk beautifully (Beysekhan Moldabayev, Field materials 2011).

All traditions and customs related to childbirth and upbringing play a great part in people's lives. The Kazakh people try to educate their children to respect the older and help the younger. Unfortunately, there is one problem still unsolved by the Kazakhs living abroad. It is the problem of the Kazakh language. Kazakh children do not know their mother tongue due to the absence of Kazakh-language schools and the abundance of Russian schools.

All the collected materials demonstrate that there are many similarities in the traditions and customs related to childbirth and upbringing of Kazakhs living in different regions of Central Asia. Though the Kazakh diaspora in the neighboring countries of Central Asia seems to maintain some national traditions and customs, they have gradually changed due to the pressure and influence of the local social institutions. Thus, we may conclude that such ethnographic distinctions and features of the Kazakhs in Central Asia require a serious research. 


\section{RESULTS AND DISCUSSION}

\section{The chronological framework of the history of the Kazakh diaspora formation in Kyrgyzstan}

The main stages of the Kazakhs' settlement in Kyrgyzstan can be divided as follows: the first one is determined by the inter-ethnic contacts existing since the Middle Ages, when the borders of neighboring nomadic tribes were not strictly outlined. The second stage is related to various administrative-territorial reforms of tsarist Russia in the nineteenth and twentieth centuries. The third stage is related to the national territorial demarcation in Central Asia, carried out by the Soviet authorities in the 1920s. All these historical circumstances became the most significant factors in the formation of the Kazakh diaspora in Kyrgyzstan.

The Kazakh diaspora was largely created because of the administrative and enforcement actions of the tsarist empire, based on the principle "divide and rule". Such an event as the exodus of Kazakhs from their ancestral lands in 1916, after the defeat of the national uprising, is an obvious example of the local population's reaction to the tsarist colonial policy. Archival materials depicting how large groups of Kazakh and Kyrgyz population from Almaty, Pishpek, Dzharkent, Lepsinsk, Kopalsk, and other uyezds fled abroad to the neighboring China testified to these migrations. It is not possible to determine the exact number of people who fled due to the events of 1916 and the "red terror" of 1917-1918, but rough estimates show that it was about 100,000 Kazakhs. However, after the establishment of the Soviet power and the land reforms of 1921-1922, many Kazakhs and Kyrgyz returned from China but because they feared to lose their property, they preferred to stay on the lands of Kyrgyz manaps in Issyk-Kul, Pishpek, and Karakul districts. Ethnographic materials collected by the authors confirmed these facts.

\section{Specific features of Kazakhs' resettlement in Kyrgyzstan}

The authors defined the areas of Kazakh settlements in the 1920s, after their return from China, then in the 1930s, after the crop failure and famine, and in the 1960s-1970s, when they came to Kyrgyzstan as labor migrants. So, in 1922, during a four-month period, 307 Kazakh families comprised of 824 people returned to Kyrgyzstan. Most Kazakhs settled in the suburban areas of Bishkek, where they formed centers of compact settlement, such as the villages of Manas, Razdolnoye, Alty Barak, and others.

Such tragic events as the crop failure and famine, food shortages, and other economic hardships, caused a large flow of migrants, who moved from Kazakhstan to Kyrgyzstan in 1932-1933. As a result, by 1939 the percentage 
of the indigenous population - the Kyrgyz - decreased to 51.7 percent, which, in turn, increased the size of other ethnic groups. Therefore, the number of Russians increased to 20.8 percent, and that of Kazakhs - to 1.6 percent. At that time, the number of Kazakhs in Kyrgyzstan was 23,925 (1.6 percent out of the total population of the country). In the 1960s-1970s, due to labor migration, 21,263 people moved from Kazakhstan to Kyrgyzstan. A significant influx of migrants - 5,469 people - came from the Dzhambul region, which is explained by the proximity of the region.

\section{Problems of demarcation of ethnic territories}

The demarcation of the ethnic territory of Kazakhstan and Kyrgyzstan was based on the results of numerous ethnographic expeditions as well as the works of Russian and Soviet orientalists, and Kazakh and Kyrgyz ethnographers. The ethnic-territorial demarcation in the republics of Central Asia caused fierce disputes regarding the partitioning of pastures for grazing and haymaking. For instance, dzhaylyau Susamyr at the Zailisky Alatau foothills was added to Kyrgyz lands and immediately became the subject of contentious conflicts between the neighboring Kyrgyz and Kazakhs. Debates over lands consequently led to the increase of the Kazakh diaspora on the territory of Kyrgyzstan. Another factor that caused the growing number of Kazakhs in Kyrgyzstan is connected with the Kazakhs-Argyns migration from the Akmola region in search of rich pastures at the border of Kyrgyzstan in the late twentieth century. One of the archival documents contained information about the desire of 42 Kazakhs-Argyns' households to stay in the Kyrgyz territory.

\section{The reasons for oralmans' repatriation from Kyrgyzstan}

The total number of repatriates-oralmans to their historic homeland, as compared with the percentage of repatriates from the Kyrgyzstan Republic, is negligible, especially in comparison with diasporas from other regions of Central Asia. It can be explained by the following reasons: first, the relatively stable financial position of Kazakhs in Kyrgyzstan; second, lack of nostalgia due to the close location of both nations' territories. The outflow of Kazakhs from Kyrgyzstan is represented mainly by younger generation, who move to Kazakhstan to settle in economically and culturally more developed megalopolises such as Astana and Almaty.

Though Kazakh people in Kyrgyzstan continue to maintain the traditions and rituals of the native country, they are slowly adopting new practices borrowed from the local population. Meanwhile, widely spread intermarriages between the Kyrgyz and Kazakhs significantly affect the convergence of some social institutions. 


\section{CONCLUSION}

The history of the formation of the Kazakh diaspora in Kyrgyzstan is related to such historical events as the 1916 national-liberation movement, the demarcation of the national territory of ethnic republics in Central Asia in 1924-1928, collectivization, famine and crop failure in 1928 and in 1932-1933, labor migration, and some other factors. Most of the Kazakh people settled on the territory of Kyrgyzstan, which belongs to the Uisun tribe. ${ }^{35}$ They were the first to come back from China. Smaller numbers of Kazakhs were Argyns from Central Kazakhstan (Shet and Karkara regions) together with the other Kazakhs from Semey Oblast (Tobykty and Naiman clans). The second group migrated to Kyrgyzstan after collectivization and crop failures that led to famine and devastation of the farms. In the 1930s, Kazakhs settled in Kyrgyzstan, in the regions of Alameddin, Sokuluk, Manas, Priozernoye, Razdolnaya, Altybarak, and others. Other destination centers were cities of Bishkek, Tokmok, Talas, $\mathrm{Shu}$, and the Tien Shan and Issyk-Kul areas.

Over the past ten years, the Kazakh population in Kyrgyzstan has started to decrease. The main reasons of the Kazakh population's outflow from Kyrgyzstan are socio-economic, spiritual, cultural, and partly political ones, while successful socio-economic development, political stability, and inter-ethnic accord attract our kinsmen to Kazakhstan.

We may still consider the Kazakhs who live in the neighboring regions of Kazakhstan as an indivisible part of the Kazakh ethnos. The most important task of modern Kazakhstan as a sovereign state is to have strong and attractive national idea and effective foreign policy. Studies of migration history, Kazakh culture maintained by our kinsmen abroad, their mentality, ethnic identity, traditions, and lifestyle create a strong foundation for realizing the aims that our state has set for sustainable and prosperous life of our people.

\section{NOTES}

1 Oralmans are Kazakhs who return to Kazakhstan from abroad. They migrated from the native country mainly due to certain political and economic reasons from the eighteenth to the twentieth centuries.

2 Today Kazakhs live in forty countries.

3 Before the revolution of 1917, Kazakhs were called Kyrgyz due to the pre-revolutionary scientific tradition in Russian ethnography. The present population of the Kyrgyz Republic was called Kara-Kyrgyz.

4 A large pasture named Susamyr situated in Kyrgyz and Kazakh republics but used for a long time by the Kazakh nomads.

5 Bishkek, formerly (1862-1926) Pishpek, or Bishkek, and (1926-1991) Frunze. 
6 Administrative unit in tsarist Russia.

7 In the early twentieth century Semirechenskaya Oblast consisted of six uyezds (counties).

8 Kyrgyz was the old name of Kazakhs used in tsarist Russia.

9 Here it means the Kazakh Autonomous Republic of the Russian Soviet Socialist Federative Republic. Kyrgyz means Kazakh.

${ }^{10}$ Kyrgyz aristocracy.

${ }^{11}$ All large pastures had names.

12 They were later integrated into the Kyrgyz Autonomous Region.

${ }^{13}$ Kamyshovskaya village was included in the Kyrgyz region.

14 The middle part of Argyn village was left in the Kazakh ASSR, and was transformed into an enclave because most of the village became part of the Kyrgyz territory.

${ }^{15}$ On average every family had $4-5$ people.

${ }^{16}$ The Dzhambul region borders on the Talas region (Kyrgyzstan).

${ }^{17}$ Modern Almaty region was also called Semirechye.

${ }^{18}$ It was the first time that a census was conducted in Tsarist Russia.

${ }^{19}$ Kazakhs.

${ }^{20}$ Half-Kazakhs.

21 The groom's dish.

${ }^{22}$ Bride's sister-in-law here means the wife of her brother.

${ }^{23}$ Same if the bride has married brothers.

${ }^{24}$ Kyz uzaty means a party when bride's parents say goodbye to their daughter and send her to the groom's family.

${ }^{25}$ A special song performed at the wedding party.

${ }^{26}$ A song performed during kyz uzatu. Synsyma and synsu are different names of one type of song.

${ }^{27}$ Removing the bride's veil.

${ }^{28}$ A specially invited singer who conducts the ceremony.

${ }^{29}$ Sheep.

${ }^{30}$ Ranging from 10,000 to 40,000 tenge (currency in Kazakhstan).

${ }^{31}$ Begging.

${ }^{32}$ Putting in the traditional cradle. 
${ }^{33}$ It is a race but people call it marathon for fun.

${ }^{34}$ Beads that are believed to protect from the evil eye.

${ }^{35}$ The Uisun tribes have populated these lands since the medieval period. They were part of the Senior Zhuz (horde). In the past the Kazakh khanate consisted of three zhuzes (Senior Horde, Middle Horde, and Junior Horde).

\section{ARCHIVAL SOURCES}

CSA RK = Central State Archive of the Republic of Kyrgyzstan:

F. 847 , op. 1, d. 27, pp. 128-129, 136-137

F. 21 , op. 3 , d. 105 , pp. $6-7,69,71,105$

F. 21 , op. 1, S. 5, L. 61,63

F. 21 , op. 5 , p. 6,109

F.105, op. 31 , D. 324 , p. 47

CSA RU = Central State Archive of the Republic of Uzbekistan:

F. r-1, op.1, d. 707, L. 95-96.

F. 1, op. 4, d. L. 1390, pp. 2, 9.

F. r-1, op. 1, d. 707, pp. 94-95.

\section{LIST OF INFORMANTS (FIELD MATERIALS 2001-2011)}

Kaliyev, Bugibay, b. 1927, tribe - Argyn. Village Manas, Kyrgyzstan.

Abdibaev, Kasen, b. 1918, tribe - Argyn. Village Manas, Kyrgyzstan.

Almaganbetova, Ulsara, age 97, tribe - Argyn. Bishkek, Kyrgyzstan.

Mukhanbetova, Dastagul Omarovna, b. 1941, tribe-Argyn. Village Razdolnoye, Kyrgyzstan.

Balabekova's Marfu, 72 years old, tribe - Argyn. Village Manas, Kyrgyzstan.

Abisheva, Maken, 98 years old, tribe - Tobykty. Bishkek, Kyrgyzstan.

Madibekov, Bulekbay Tyrybolsynuly, 71 years old, tribe - Tarykty. Village Akzhar,

Sokuluk district, Kyrgyzstan.

Kassenova, Azharkul, b. 1928, tribe - Bestorsyk. Village Manas, Kyrgyzstan.

Moldabayev, Beysekhan, b. 1941, tribe - Botbay, Senior Horde (or Great Horde), Bishkek, Kyrgyzstan.

Imanbayeva, Uldana, 83 years old, tribe - Saryuysin, Bishkek, Kyrgyzstan.

Myrzabekova, Gulsara, 78 years old, tribe - Saryuysin. Village Razdolnoye, Kyrgyzstan. Aymukhanbetova, Kulyash, 76 years old, tribe - Botpay. Village Razdolnoye, Kyrgyzstan.

\section{REFERENCES}

All Central Asia 1926 = Vsia Sredniaia Aziia 1926 god. [All Central Asia 1926.] Tashkent: Sredne-Aziatskoe otd. Rossiisko-Vostochnoi torgovoi palaty.

Argynbayev, Khalel 1996. Kazaқ̧ otbasy. [Kazakh Family.] Almaty: Kainar.

Arkhipov, Nikolai 1930. Sredne-Aziatskie respubliki. [Central Asian Republics.] Moscow \& Leningrad: Gos. izd-vo. 
Baltabayeva 2011 = Baltabaeva, Kulgazira. Kazakhi Kyrgyzstana: sravnitel'nyi analiz itogov natsional'nykh perepisei 1999 g. i 2009 g. [Kazakhs of Kyrgyzstan: A Comparative Analysis of the National Censuses' Results in 1999 and 2009.] In: K.N. Baltabaeva \& T.E. Abilova \& E.U. Baidarov \& A.T. Suleimenova (comps.) Natsional'naia ideia - faktor ob"edineniia sootechestvennikov vo blago nezavisimogo Kazakhstana. [National Idea: Factor of Unification of Countrymen for the Benefit of Independent Kazakhstan.] Materialy mezhdunar. nauch.-teor. konf., g. Almaty, 14 sent. 2011 g. Almaty: Atazhurt, pp. 112-118.

Berry, John W. 2003. Conceptual Approaches to Acculturation. In: K. Chun \& P. Balls Organista \& G. Marin (eds.) Acculturation: Advances in Theory, Measurement, and Applied Research. Washington DC: American Psychological Association, pp. 17-37.

Bizhanova, Aliya 2001. Semeino-bytovye obriady kazakhov nizov'ia Amudar'i (vtoraia polovina XIX-seredina XX vv.). [Family and Household Ceremonies in the Lower Reaches of Amu Darya (Second Half of the 19th - Middle of the 20th Centuries).] Avtoreferat dissertatzii na soiskanie stepeni kandidata istoricheskih nauk. Nukus: Nukus State University.

Census 2000 = Rezul'taty perepisi 1999. [Results of the 1999 Census.] Almaty: Statisticheskoe agentstvo.

Dave, Bhavna 2010. Politics of Modern Central Asia: The Changing Geopolitical Context. Abingdon \& New York: Routledge.

Grodekov, Nikolay 1889. Kirgizy i karakirgizy Syr-Dar'inskoi oblasti. [The Kyrgyz and Kara-Kyrgyz of the Syr-Darya Region.] Tashkent: Tipo-lit. S.I. Lakhtina.

Kalshabayeva, Bibiziya 2011. Ortalyқ Aziiadazy қ̧azaқ̧tar (tarikhi-etnografiialyқ̧zertteu). [Kazakhs in Central Asia (Ethnographic Research).] Almaty: Қаzaқ universiteti.

Kalshabayeva, Bibiziya 2014. Central Asian Kazakhs (Historical-Ethnographic Research). Almaty: Arys.

Kalshabayeva, Bibizia \& Seisenbayeva, Akbota 2013. Some Problems of Repatriation and Adaptation of Representatives of the Kazakh Diaspora of Central Asia in the Historic Homeland. Middle-East Journal of Scientific Research, Vol. 15, No. 1, pp. 20-26. DOI: 10.5829/idosi.mejsr.2013.15.1.11054.

Karutts 1910 = Karutts, Rikhard. Sredi kirgizov i turkmenov na Mangyshlake. [Among the Kyrgyz and Turkmens in Mangyshlak.] Transl. by E. Petri. St. Petersburg: Izdanie A. F. Devriena.

Koblandin, Kalybek 2008. Sovremennye migratsionnye trendy iz Uzbekistana v Kazakhstan. [Modern Migration Trends from Uzbekistan to Kazakhstan.] Izvestiia NAN RK, No. 2, pp. 43-47. Available at http://nblib.library.kz/elib/ library.kz/journal/\%D0\%9A\%D0\%BE\%D0\%B1\%D0\%BB\%D0\%B0\%D0\%BD\%D 0\%B4\%D0\%B8\%D0\%BD\%20\%D0\%9A.\%D0\%98.\%D0\%B0.pdf, last accessed on 12 July 2019.

Koblandin, Kalybek 2012. Tekushchii arkhiv Vsemirnoi Assotsiatsii kazakhov. [The Current Archive of the World Association of Kazakhs.] Almaty: n.p.

Kolbasenko, Ivan 1889. Nekotorye kirgizskie obychai i pover'ia, imeiushchie akusherskoe znachenie. [Some Kyrgys Customs and Beliefs with Obstetric Value.] Protokoly Kievskogo akushersko-ginekologicheskogo obshchestva, Vol. 5, pp. 47-49.

Krongardt, Gennadiy 1989. Naselenie Kirgizii v poslednei treti XIX-nachale XX veka. [Demographics of Kyrgyzstan in the Last Third of the 19th - Early 20th Centuries.] Frunze: Ilim. 
Masalsky 1913 = Masal'skii, Vladislav (comp.). Rossiia: Polnoe geograficheskoe opisanie nashego otechestva. T. 19: Turkestanskii krai. [Russia: Complete Geographical Description of Our Fatherland. Vol. 19: Turkestan.] St. Petersburg: Izdanie A. F. Devriena. Available at http://elib.shpl.ru/ru/nodes/170-t-19-turkestanskiykray-1913, last accessed on 12 July 2019.

Materials 1926 = Materialy po raionirovaniiu Uzbekistana. [Materials on the Zoning of Uzbekistan.] Vol. 1. Samarkand: n.p.

Materials $1927=$ Materialy komissii ekspeditsionnykh issledovanii AN SSR: Osobennosti sel'skogo khoziaistva Adaevkogo uezda. Issledovanie $1926 \mathrm{~g}$. [Materials of Commissions of Research Expeditions of the Academy of Sciences of the USSR: Agriculture of Adaevsky Uyezd. Research of 1926.] Vol. VI. Tashkent: n.p.

Mendikulova, Gulnara 1997. Istoricheskie sud'by kazakhskoi diaspory. Proiskhozhdenie i razvitie. [Historical Destiny of Kazakh Diaspora: Origin and Development.] Almaty: Gylym. Available at http://bibliotekar.kz/istoricheskie-sudby-kazahskoidiaspory-g, last accessed on 12 July 2019.

Mendikulova, Gulnara 2006. Kazakhskaia diaspora: istoriia i sovremennost'. [Kazakh Diaspora: Past and Present.] Almaty: Reis.

Pallas 1778 = Pallas, Petr S. Puteshestvie po raznym provintsiiam Rossiskogo gosudarstva. [Travelling to Different Provinces of the Russian State.] Vol. 2. St. Petersburg: Imperatorskaia Akademiia Nauk.

Pashino, Petr 1868. Turkestanskii krai v 1866 godu. Putevye zametki. [Turkestan in 1866. Travel Notes.] St. Petersburg: Tip. Tiblena i Nekliudova.

Sartbayev 2009 = Sartbaev, Maksut. Kazakhi Kyrgyzstana. Proshloe i nastoiashchee. [Kazakhs of Kyrgyzstan: Past and Present.] Bishkek: Ilim.

Schatz, Edward 2004. Modern Clan Politics: The Power of "Blood" in Kazakhstan and Beyond. Seattle: University of Washington Press.

Shalekenov, Uakhit 1966. Kazakhi nizov'ev Amu-Dar'i. K istorii vzaimootnoshenii narodov Karakalpakii $v$ XVIII-XX vv. [Kazakhs of the Lower Reaches of Amu Darya River: To the History of the Relationship of Karakalpakastan Peoples in the 18th-19th cc.] Tashkent: Fan.

Sheffer, Gabriel 1986. Modern Diasporas in International Politics. London: Croom Helm.

Statistical Data 2001 = Statistical data obtained from the Statistics Department of the Kyrgyz Republic in 2001 (in possession of the author).

Svanberg, Ingvar 1989. Kazak Refugees in Turkey: A Study of Cultural Persistence and Social Change. Uppsala: Academiae Ubsaliensis.

Tatimov, Makash 1992. Khalyқ̧nama nemese san men sana. [Folklore or Number and Consciousness.] Almaty: Zhazushy.

Toleubayev 1991 = Toleubaev, Abdesh. Relikty doislamskikh verovanii $v$ semeinoi obriadnosti kazakhov (XIX-nachalo XX v). [Relics of Pre-Islamic Beliefs in Family Rites of the Kazakhs (19th and Beginning of the 20th Centuries).] Almaty: Gylym.

Zhelokhovtsev, V.S. 1989. Izmenenie etnicheskogo sostava naseleniia Kirgizii (20-30-e gody $\mathrm{XX} v$ ). [Changes in the Ethnic Composition of the Population of Kyrgyzstan (20s-30s of the 20th Century).] In: Aktual'nye problemy etnografii i arkheologii Kyrgyzstana. Collection of articles. Frunze: Izdatel'stvo Akademii nauk Kyrgyzskoi SSR. Zhelokhovtsev, V.S. 2000. Naselenie Kirgizii. [Population of Kyrgystan.] Bishkek: n.p. Yearbook 1924 = Statisticheskii ezhegodnik 1917-1923. [Statistical Yearbook 1917-1923.] Vol. 1. Tashkent: Tsentral'noe statisticheskoe upravlenie Turkrespubliki. Available at http://libarch.nmu.org.ua/handle/GenofondUA/24292, last accessed on 15 July 2019. 


\title{
MYTHOLOGY OFFERS GOOD ARGUMENTS FOR SOLVING THE PUZZLE OF MIGRATION
}

\author{
Interview with Mexican Mythologist \\ Martín Cuitzeo Domínguez Núñez
}

\section{Interviewer Henri Zeigo}

This year the Estonian Literay Museum organized the 13th Annual International Conference on Comparative Mythology in cooperation with the Centre of Excellence in Estonian Studies. At the end of the conference I had a chance to conduct an interview with Mexican mythologist Martín Cuitzeo Domínguez Núñez, who works at the Center for Research and Advanced Studies in Social Anthropology (CIESAS), Mexico City. He is an expert on the astronomical culture of the Pa ipai people. Also, Domínguez Núñez is one of the organizers of the next international conference on comparative mythology. In this interview he talks about Mexican myths, reveals some details about the forthcoming conference, and draws parallels with Estonian mythology.

Martín Cuitzeo Domínguez Núñez, how did you become interested in mythology as a young man?

There are many answers to this question. First of all, as a young child I liked myths, specifically Greek mythology, and on the other hand, I liked prehispanic mythology and legends from the colonial period. During my BA studies I started to study myths originating from different parts of the world, but also new stories from ancient Mexico. Finally, I focused on Mesoamercian and northern Mexican indigenous myths. Also I think that the Mexican context is very multicultural; here you can meet people with very different backgrounds. In Mexico, myth is a part of the daily life. You are at a party, and suddenly an old lady starts to tell you old stories. These events may be weddings or family reunions of my friends. At some point you are engaged in a conversation with an old women or an old man and spontaneously they start talking about witches, fire balls in the air, and also about how to protect yourself from "nahuales". These are human beings that have the ability to transform into animals. This cultural context probably explains why I became a mythologist. 


\section{Can you remember any myths from your childhood which have had an effect on shaping your personality?}

My grandmother told me and my brother a short story about why little kids are not able to say bad words. This is a story of Child Jesus; when he said some bad words he became a pig for some days because God decided it was bad. After this punishment he became a child again. This story also explains why it was bad to eat pork - this was because of the transformation of Jesus into a pig. With this story, my grandmother warned me against behaving badly.

An Aztec myth of the origin of the sun is another story I remeber. When I was a kid, as part of my primary school literature, I read a myth about how a god performed a sacrefice to become the sun. His name was Nanahuatzin. And another god, Tecutzitecatl, did the same. But there was too much light in the sky and the gods decided to throw rabbits into the face of the second god. And that is how we got the sun and the moon, and the latter has the face of a rabbit.

Every promising scientist has been inspired by some role models. Who are your major influencers in the academic world?

I think I have three main influencers. The first one is Algirdas Julien Greimas, a Lithuanian semiotician who also investigated Lithuanin folklore and mythology. He has most certainly been my major influencer. Greimas' methodology for analyzing narratives is one of the main tools I use to analyze myths. I like his concepts of surface elements and actants or functions in stories. Secondly, Spanish Professor Tomás Pollán, who specializes in the history of mythology. At his short courses taught at the National Autonomus University in Mexico City I have learnt about the concepts and theories about myths proposed by Levi Strauss, Bronislaw Malinowski, and Hans Blumenberg. Pollán has an intersting way of teaching mythology theory. He talks not only about the historical context of each author and the main points of their theories, but also about the intellectual context of each theory and their main influences. I would also like to mention Joseph Campbell. Today I am more critical of him, but his theory about the presence in all human cultures of the myth of the hero is quite persuasive. Addionally, I can say that two more Mexican mythologists have influenced me. They are Alfredo López Austin and Mario Arturo Galván Yáñez. Both have been my teachers. López Austin has developed a historical methodology to understand the Mesoamerican mythology and cosmovision. He uses the concept of the existence of a hard core in the Pre-Columbian mythology. Galván Yáñez has developed the concept of mythical systems. A mythical system is a set of rules or related principles that organize and hierarchize different myths among themselves. 


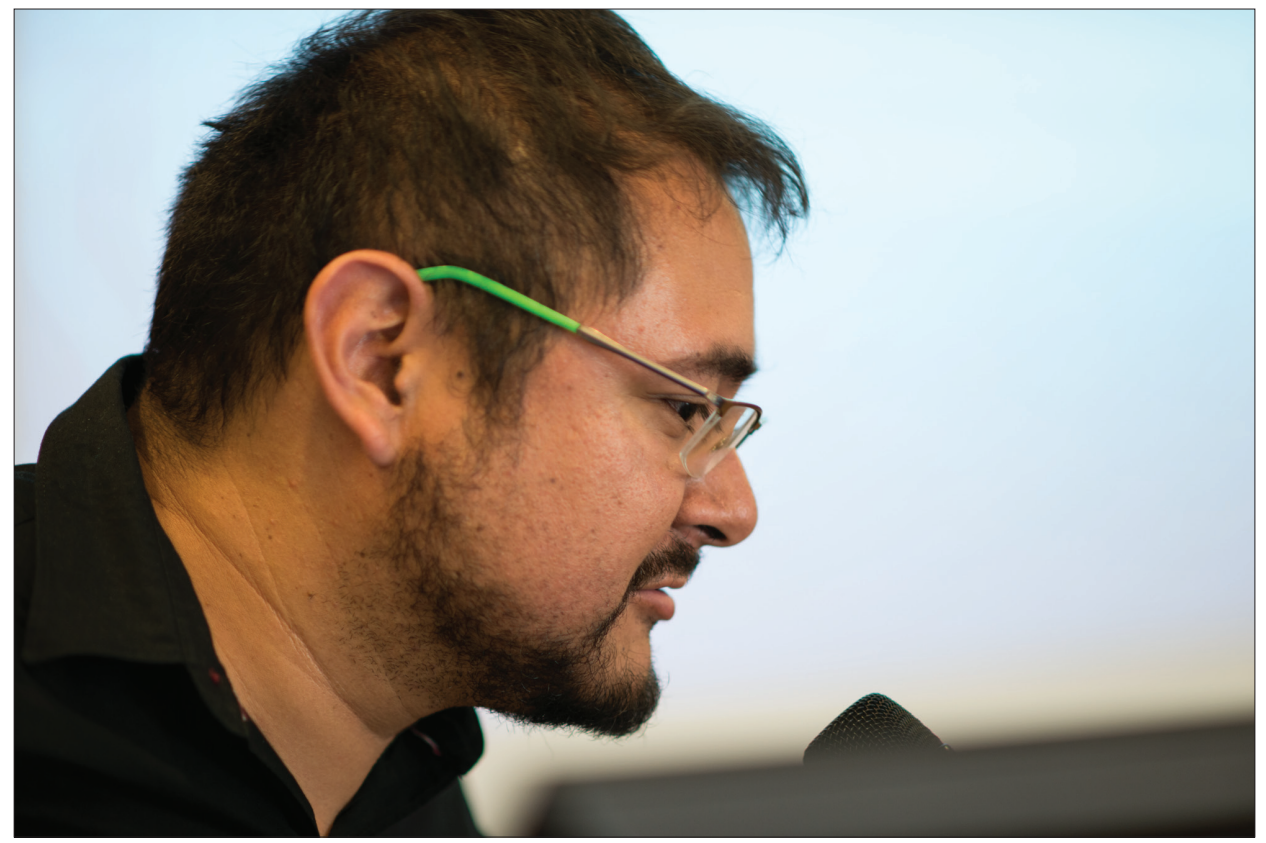

What is your main research subject today? Can you talk a little bit about it?

My main research today is astronomical culture among the Pa ipai people. I am investigating how social and historical changes in northern Mexico are related to what we think of the sky. This is the subject of my doctoral thesis, in which I apply the interdiciplinary approach that combines astronomy, antrophology, etnography, and semiotics.

During your stay in Tartu you met Professor Peeter Torop. Did you talk about your research? Why is his feedback important to you?

Professor Peeter Torop, an international expert on the topic of cultural semiotics, belongs to one of the most important schools of semiotics in the world, the Tartu school. I showed him my work on cultural astronomy and mythology of the sky and he came up with some useful ideas. For example, he suggested that I classify and analyze semiotically the different sorts of astronomical-mythological images I have collected during my fieldwork with the Pa ipai people. I need to add that his feedback was important to me because my mythological research of the Pa ipai people has a semiotic component. I was looking for advice on methodology. Professor Torop introduced me to the sources on the topic of semiotic methodology which are difficult to find in Mexico. 


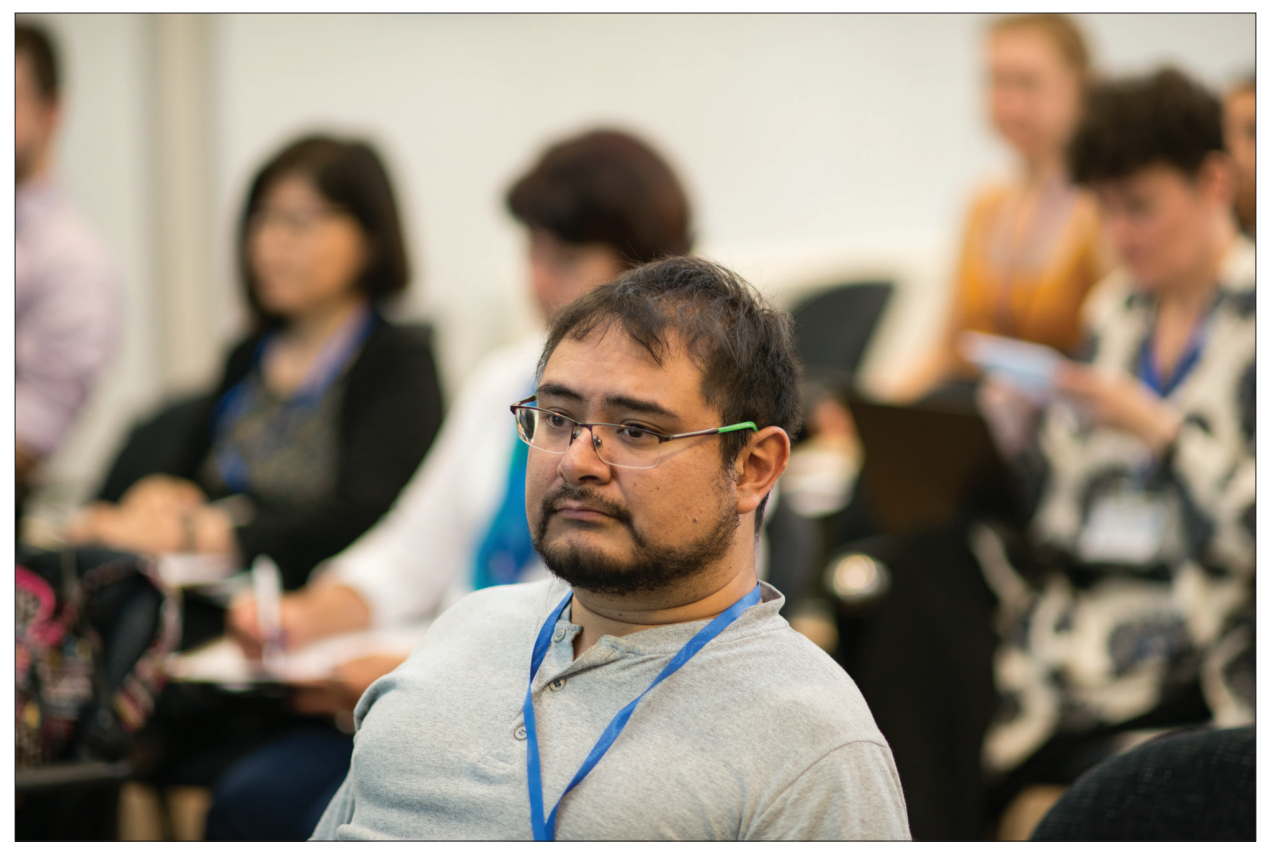

Is there something very specific about Mexican myths to distinguish them from what we have in Europe?

When we talk about Mexican myths, we talk about different kinds of myths - the ones of pre-Hispanic times and the ones after the conquest. In the latter case we have a combination of indigenous and Catholic beliefs. On the other hand, pre-Hispanic mythology was quite different from European myths because of the cosmovision and cultural background. It used lots of local elements. They talked about jaguars, ancient reptiles, crocodiles that lived namely in Mexico. Also Mexican mythology has some gods that do not exist in European cosmology. For example, Quetzalcoatl, which is a feathered snake and was related to the wind. Also Tláloc - the god of rain, which is depicted with goggle eyes and teeths and fangs. The idea of death and myths thereof were also different than the European perspective. In Aztec and Mayan cosmology, but also in other pre-Hispanic cultures, such as Mixtec, death was part of the daily life. The Maya and the Aztecs believed that it was needed to cross a river - the River Chignahuapan - with the help of a dog, to travel to the kingdom of the dead. In that kingdom lived Mictlantecuhtli, the Lord of the Dead. Today in rural Mexico, but also in the cities, myths about the dead are part of the daily life. People believe that on November 1 and 2 the souls of the dead return to 
the earth. They elaborate complex "ofrendas" with a local flower named cempaxochitl (Mexican marigold). Also they leave bread and tortillas for the dead.

Today many Mexicans live in the United States. Do you think that due to the growing migration Mexican myths can transfer to the USA and thereby become a part of American mythology?

This is probably happening already. I know that there are hundreds and thousands of indigenous people who have migrated from Mexico to the United States. The children of these people speak both English and their indigenous language, and I am sure that they have their own stories. These stories could be incorporated into North-American mythology and folklore. I can give a specific example: my mother is a follower of a Mexican religion named Espiritualismo Trinitario Mariano. It is a combination of Catholic, spiritual, and indigenous beliefs. Today, this religion has some temples in the United States. So, this is an example of how religious thoughts and mythology of one country can be incorporated into another.

The 21st century features abundant high technology, and thanks to technical and computer sciences we can measure objects and make accurate mathematical predictions of how something works. Why should we be interested in studying myths nowadays? It does not seem practical enough in terms of staying alive in our society.

Yes, I think that myths are important in contemporary societies. Let me tell you something. In Latin America we perceive myths differently, because they constitute a part of our daily life. At the same time myths are mixed with technology. It is imperative to understand life in other ways, to make sense of society. Myths could enrich our understanding of others and help us make our experience of the others more meaningful. In my opinion, if American people read more Latin-American myths, they would be more open to migration. It is the same in Europe. If Europeans read about the mythology of other cultures, namely African and Middle-Eastern cultures, they would probably be more open to migration and interaction with people from other cultures.

It seems to me that young people unconsciously explore myths - how else can we explain that there are so many fans who adore "Game of Thrones" or the Marvel comics heroes. What is your opinion? Are youngsters able to grasp myths by watching these movies?

Here we are dealing with a kind of social phenomenon that some philosophers have described in the past. Take, for example, Zygmunt Bauman, who makes 
a distinction between identification and identity. Identification is a kind of trend here; it consists in a superficial link with an ideology or a way of life. Identity is something deeper, it is linked with personal and collective experiences, with social memory. What happens now when modern people watch these movies is a mark of identification, not identity. However, I guess that when young people try to search the roots and genesis of these movies and when they read the myths behind the scene, they can turn the identification process into identity.

The 14th international conference of comparative mythology is held in Mexico next year and you are one of the organizers. Could you tell me something about it?

Yes, the conference will be held in the second week of June in Mexico City. We have planned to have a conference both in Spanish and English, because most Mexican people do not speak English. That is why we need interpreters. The main topic of the conference is migration in myths and the mythology of death. Why this kind of choice? Migration is a crucial topic in politics and I hope that mythology could provide some relevant arguments to the ongoing debate. And death - well, it is one of the central elements in Mexican myths. It is a good opportunity to share our rich mythology with other researchers and to have a dialogue with them.

On the other hand, in our contemporary world inequality, war, poverty, and violence have provoked massive migrations from the third-world countries to Europe and the United States. Migration is not something new in human history and mythology can help us realize how different cultures have understood migration. For example, for a long time there was a belief in Aztec culture that their people were created in a place of seven caves, named Chicomoztoc. They started their migration from this mythical place to Tenochtitlan, the capital of the Aztec Empire. This migration took many generations to be completed.

Death is also a contemporary issue and it is, to a certain extent, related to some of the causes of migration: violence and war. In many third-world countries death, and especially violent death, is part of the daily life; sometimes this is why many families decide to move to other parts of the world. Also death, independently of our country of origin, is our final destiny as human beings. The modern way of life does not permit us to think too much about it. Mythology can help us understand and think about death in other ways. For example, among the Aztec and Scandinavian cultures the way you die determines the place to which you go after death. Nowadays people do not think about it, but to think about how we die makes us think of how we live. 
I know that this is your first visit to Estonia. During these few days, have you learnt something about our mythology, or maybe even found something in common with Mexican mythology?

Recently Mare Kõiva mentioned that you (in Estonia) have myths about old trees. When listening to her lecture, I remembered that in Mexico we have also stories of trees. Aztecs believed that five enormous trees separate the earth from the sky. They believed that thousands of years ago the world was created from the body of a female crocodile named Cipactli. After hundreds of years of loneliness Cipactli felt sad and started crying, and her tears flooded the world. The gods decided to separate the world from the water again and they transformed the body of Cipactli into five trees. Four of them were located in each corner of the universe and one was located at the centre. That is the story about trees and the origin of the world.

I can also detect some similarities in astronomical knowledge, the origins of which lie in folk songs. You can find the same in our songs. There exist indigenous songs that talk about the stars and constellations.

What is more, I can see some parallel developments in folklore studies. When we were introduced to your recording techniques in the early 20 th century, I realized that our students collected similar information about Mexican folk tales. They went to the countryside and recorded everything they heard from the villagers. The stories are mostly about farming. I think this is also common to our nations.

\section{PUBLICATIONS BY MARTÍN CUITZEO DOMÍNGUEZ NÚÑEZ}

2018 - Mito, legitimación y memoria social a través de la imagen: La escultura prehispánica de una cabeza de serpiente en Tehuacán, Puebla (Myth, Legitimation and Social Memory Through the Image: A Snake Head Prehispanic Sculpture in Tehuacán). Boletín de Antropología, Universidad de Antioquía, Vol. 33, No. 56, pp. 39-77. Available at http://aprendeenlinea.udea.edu.co/revistas/index.php/ boletin/issue/view/3251/showToc.

2011 - Astronomía en el Tetzcotzinco (Astronomy in Tetzcotzinco). Legado astronómico (The Astronomical Legacy). Daniel Flores Gutierrez et al. (Editores). México: UNAM, pp. 283-292.

2010 - La articulación de la significación en dos paneles del sitio de arte rupestre Mirador de Bárcenas, Mesa de los Santos, Colombia (Enunciative Dynamic in Two Rock Art Panels at the Site Mirador de Bárcenas, Mesa de los Santos, Colombia). Revista S, Vol. 4, pp. 145-153. Available at https://revistas.uis.edu.co/index.php/ revistaS/article/view/1960/2333. 
2009 - Las Manitas Rock Art Site in Cañada de Cisneros, Tepotzotlán, México: An Analysis Using Visual Semiotic Tools. American Indian Rock Art, Vol. 35, pp. 161170. Available at https://www.academia.edu/5243092/.

2005 - Pintura rupestre y liminalidad (Rock Art Paintings and Liminality). American Indian Rock Art, Vol. 31, pp. 69-77. 


\title{
BOOK REVIEW
}

\section{THE GREEK ROOTS OF MYTH CRITICISM}

\author{
Michael Herren. The Anatomy of Myth: The Art of Interpre- \\ tation from the Presocratics to the Church Fathers. New \\ York: Oxford University Press, 2017. 231 pp.
}

The roots of modern discussions of mythology are commonly traced back to ancient Greece. However, this tends to be mentioned either in vague generalizations or by spotlighting a particular writer or philosopher identified with the origin of a particular concept. For example, the idea of 'euhemerism' - i.e. the idea that gods were actually exceptional human beings who became interpreted as gods through deception or

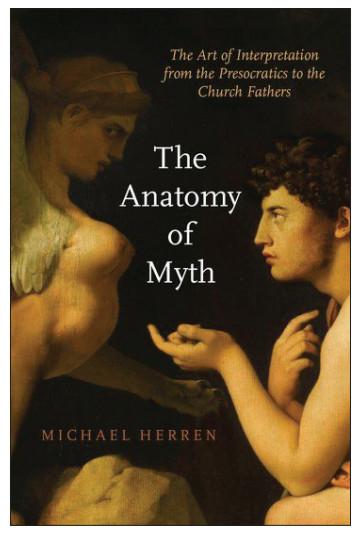
misunderstanding - is frequently identified with a certain Euhemerus, but without further elaboration. Alternately, Greeks are more generally identified with the origin of objective scientific thinking and associated philosophy, of which the objectification and interrogation of myth, rejecting it as an account of the world or its history is an organic part. Passing statements on such thoughts and connections is where most of us get our knowledge of the importance of Greeks for the study of mythology. The continuous recirculation of such claims with little or no historical context can make it difficult to untangle their accuracy, particularly when it can start to seem like a cliché that everything from geometry to democracy gets traced back to the classical world. When it comes to theories on myth, Michael Herren's Anatomy of Myth: The Art of Interpretation from the Presocratics to the Church Fathers provides an insightful and accessible analytical overview that so many of us need.

The opening words of the preface frame the work clearly in relation to its intended audience:

This is a book for students. By students I mean anyone interested in learning how ancient ideas influence modern thought and modern ways of being. My book, though written for students, is not a textbook; that is, it is not a simple summary of the main lines of myth interpretation as explained by previous scholars. Rather, it is a fresh attempt to look at the methods of interpreting the myths contained in ancient authoritative texts in the context of the history of ideas. (p. vii)

In the title, 'anatomy' refers not to the make-up of myths per se but rather to thinkers of the past performing 'anatomies' on myths, cutting them up, looking inside and coming up with explanations for what they are and how they work. Herren's work, in its turn, is an anatomy of these discussions. As he states immediately, his approach and emphasis is to trace the history of ideas. This orientation also leads Herren to explore connections of myth criticism to the history of related concepts, such as allegory and symbolism. For example, he points out (pp. 160-161) that Saussure's theory of the sign 
was presented already more than 1400 years earlier by Augustine in his explication of the symbol. Herren's Anatomy of Myth has a great deal to offer a reader of any level, and it is written in a casual yet learned style that many will find appealing.

\section{Setting the Stage}

After the preface and a list of abbreviations, the work is organized with an introduction followed by thirteen chapters. These are altogether 169 pages, which is a very manageable length. (The thirteen chapters are not grouped into larger sections; grouping into sections below is a practical tool for discussion.) Another 27 pages are given over to endnotes and bibliography. Herren is a scholar of classics and medieval studies. Readers less familiar with the classical world will very much appreciate the 20-page glossary of names and terms, which can be quite comforting if you have set the book down for a few weeks and have lost sight of the meaning of the Greek word plasma (comparable to 'fiction') or want to make sure you are not mixing up Heraclitus with Hecataeus. The book is also well-indexed. It is a book to be read and used.

The introductory chapter is excellent and should be read by all students starting to study mythology or myth criticism. The first chapter, "The Paradigm of the Poets", lays out an understanding of the key poetic works identified with Homer and Hesiod and the models of the world that they present. This becomes particularly important because Homer and Hesiod appear viewed as authors of the poems identified with them no less than Aristotle is with his works, which allows them to be interpreted as cosmologists and philosophers as discussed in some later chapters. Herren also situates the traditions identified with these poets in a cultural-historical setting with reference to other mythologies. It is characteristic of the work that the social prominence of Homer's Iliad and Odyssey is situated in relation to the historical or imagined Trojan War as the event forming the basis of a unified Greek identity (p. 15). The second chapter, "What Makes a Work Authoritative?", discusses both supernatural inspiration, so significant for the poets, and the spread of the technology of writing, fundamental to the later transmission of the poets' works as well as to the spread of philosophical and other works that engage with them. Herren is conscious of the locations of different authors and their chronology, mentioning, for example, that Xenophanes (most of the sixth century BCE and into the fifth) was born in Ionia and ended up settling in a colony in south-western Italy. For readers less familiar with the world of that time, it would have been interesting to have a bit of information about the circulation of texts in the period, but it is of course not possible to comment on everything while keeping the work to such a manageable length.

The introduction and these two chapters form foundations for discussions to follow. Subsequent chapters are organized according to the historical emergence and development of ideas about mythology. Threads of discussion are introduced in more or less a chronology of their entry into debate, and followed through sometimes several adaptations within a chapter before going back to discuss the next idea. Consequently, discussion does not follow a strict chronological progression, nor is it arranged by thinker or author, either of which would make it much more difficult to follow the development of individual lines of interpretation. 


\section{Re-Evaluating Mythology}

The third chapter, "Physis - Redefining the Gods", advances into the earliest preserved discussions of philosophers. The chapter valuably stresses that the earliest discussions and polemics were not aimed at rejecting gods as such. Instead, they are situated as contributions to debates that sought to reconcile 'gods' with changing ideologies and epistemologies of the time, such as conceiving the world as having a natural order to which gods must also conform, or construing a moral universe, within which gods should be unable to violate moral ideals. The ideas and concerns introduced in this and subsequent chapters become threads that get traced through centuries of debate across the course of the book. Throughout, Herren makes a much-appreciated effort to keep the relationship of philosophers' views on acceptance or rejections of gods (or their redefinition as a singular god-type agency) within the reader's field of vision.

Chapter 4, "Flirting with Atheism", advances into theories of gods and mythology as constructs, such as ideas that gods are projections that somehow satisfy human needs, or that they are invented as instruments of social control. Chapter 5, "Attacking Poetry", focuses on the emergence of the view that poets and poetry are suspicious or simply deceptive. Plato holds a prominent position in this discussion, which connects with questions of genre, and perspective is added by considering the changes occurring in the premises of different classical thinkers. Chapter 6, "The Beginnings of Allegory", opens the dimensions of the emerging framework of non-literal interpretation - described by Herren as "a code of substitution" - and the potential to implement that framework as an instrument of mediating ideas.

Particularly significant in Herren's approach is that he situates different ideas in relation to evolving discourses. For example, he makes the interesting proposal "that allegorical interpretation arose out of the need to defend the ancient poets" (p. 79). Placing the emergence and evolution of different frameworks for interpretation in relation to preceding discussions offers a much deeper perspective than people can normally gain on these topics without plunging into the depths of classical scholarship.

\section{Salvaging History from Myth}

Chapter 7, "Finding History in Myth", turns to the rationalization of the fantastic. The discussion brings out the tension between, on the one hand, the importance of mythoheroic agents and events, such as Theseus or Heracles and feats ascribed to them, and, on the other hand, the irreconcilability of descriptions with understandings of the natural order of the world. In "The Paradigm of Poets", Herren highlights that "[t]he Trojan War marked the watershed between myth and history," in which heroes "have no magic weapons or armor and possess no flying horses, nor can they fly or make themselves invisible" (p. 17). The turn to rationalizing heroes of still earlier eras reflects a change in thinking about the history of the world. Within this new frame of thinking, "there [wa] s no reason to believe that the past was qualitatively different from the present" (p. 85), an idea that would become a stable principle for generations of philosophers to come. Accordingly, monsters like the Minotaur had to be rejected, and the many stories 
of the past reconceived as affected by imagination or misunderstanding - the chain of thinking produced Euhermerism. The events underlying fantastic accounts might be reconstructed, for example, through the assistance of etymology, while material evidence was considered a strong foundation for affirming the historical foundation of events. Herren makes the interesting observation that classical authors might be sensitive to identifying forged writings, but seem not to reflect on the possibility that physical evidence might be tampered with.

This discussion is extremely important in bringing out the turn in thinking about time and history. Viewing the remote past as operating according to the same natural laws as the present is taken for granted today. However, it differs considerably from the way of imagining earlier eras as open to forms of the fantastic no longer deemed probable, a way of thinking found in mythologies around the world. Some readers may nevertheless stumble a bit because the chapter opens with cases of human heroes who have been said to accomplish amazing feats. The vast majority of this book's discussion concerns precisely gods and cosmogony, while some debates, such as the morality of gods, seem irrelevant to human heroes. Herren states that "[t]he Greeks knew what myths were" (p. 6) but goes on to say that they had no word for the concept, and myth never enters into philosophical discussion as a category itself (pp. 6-7). He brings up the diversity of ways in which myth has been defined, but it would have been helpful to the reader to clearly state the definition being used in the book. Such a definition could bring into sharper focus whether Greeks saw stories of impossible feats of heroes as categorically the same as stories of the consummation of sky and earth, or whether they saw these as different but considered the fantastic as equally problematic in both.

\section{Advancing Theory and Terminology}

The eighth chapter, "Theos - Rediscovering God", brings into focus a trend across schools of thought to conceive an ultimate divine agency in the background of the world, which Herren proposes may be motivated by social issues of an era, pointing to the long Peloponnesian Wars and subsequent political instability in Athens (p. 99). Chapter 9, "The Growth of Allegory", again takes up the strategies for salvaging the works of poets with a more elaborate discussion of the role of etymology. This chapter explores how the instrument of allegorical interpretation was applied in a new brand of approach that viewed Homer and Hesiod as thinkers who encoded cosmological theories into their works, anticipating those of contemporary thinkers, reconciling myths with philosophy. Chapter 10, "Saving the Poets without Allegory", follows yet another line of interpretation, traced to Aristotle, whereby the fantastic is not a concern so much as the potential for stories and agents to offer models of behaviour and action to be emulated or avoided. Chapter 11, "From Allegory to Symbolism", discusses the significant advance in thinking from treating stories as based on a code of substitution, where interpretation removes one element in replacing it with another, to symbolic interpretation, where meaning in representation is more dynamic. The development addressed in this chapter is particularly significant, although it starts off with case studies that do not keep the same pace as in other chapters. These chapters, as well as the twelfth, will be of interest well 
beyond mythology research because they link to the history of interpretive and rhetorical strategies of much broader application.

\section{Classic Myth Criticism and Christianity}

This discussion of symbolic interpretation leads to chapter 12, "Greek Exegesis and Judaeo-Christian Books". This chapter shows how the discourse of interpretation provided Christians with the tools to develop interpretations of their own religious texts, advancing and refining theories such as that of symbolic interpretation. Herren earlier points out that "[f] or the most part, Christians seemed interested in burning one another's books, not the pagan classics" (p. 61). Classical criticism also enabled Christians to utilize those classics within their own religious frameworks, even arguing that the classics had anticipated Christianity. Chapter 13, "Reflection: How Lasting Was the Greek Achievement?", does an important job of distinguishing between religious affiliation or identity on the one hand and education and text circulation on the other, stressing that, basically, early Christian thinkers had a classical rather than especially Christian education, the latter being rare. From today's perspective many readers may find it interesting that the Bible was not initially considered a text for teaching religious doctrine precisely because some texts could so easily be interpreted in undesirable ways. When considering the Greek achievement of performing anatomies on myths, not only do we find it as the heritage of Christian interpretation of biblical texts but also what appears to be a precondition for the survival of so much classical mythology in Christian milieux.

These last chapters are extremely interesting and valuable, but my impression was that the book ends a bit abruptly. Chapter 12 carries discussion of myth criticism into the era of the Church Fathers, as promised in the title, and this is complemented by the brief, five-page discussion in chapter 13. I must admit, however, that I was a bit surprised by the limited scope of the latter chapter. When the introduction stages discussion so wonderfully by commenting on continuities of classical mythology and myth criticism through the present, I anticipated a correspondingly broad closing discussion. Of course, there had to be limits to maintain the book's concise length. The book is, I think, very strong as it stands, but the concluding chapter was surprisingly light, and seemed simply to follow on the preceding chapter rather than to provide a conclusion to the book as a whole.

\section{Summation}

The value of Herren's book should not be underestimated, and I unequivocally recommend it to anyone interested in the history of myth and myth criticism. It is easy and enjoyable to read and filled with a fascinating array of information, making connections that shape into clear and compelling arguments. Tracing different threads through centuries of discussion leaves the reader a dynamic overview of not only contributions of classical authors to ways of interpreting or anatomizing myths, but also how these relate to one another, evolve over time, and link to the cultures and historical contexts 
in which they emerged and progressed. Today the different approaches discussed appear as theoretical frames for the interpretation of objectified 'myths'. The outcome of Herren's nuanced anatomies of the different anatomies is that they emerge as contributions to broader discourses about mythology, what it is, and how it relates to the world or society. These discourses reflect tensions between inherited traditions and changing ideas of different times, traditions that get redefined, rejected and also reclaimed and reinvented. This was not owing to a dichotomy of 'myth' versus 'science' that has become so commonplace, but rather in the confrontation of inherited discussions and descriptions of the world and how it works with the ideas held by educated elites on the one hand and philosophers on the other - ideas that may seem no less mythic from the perspective of today. 

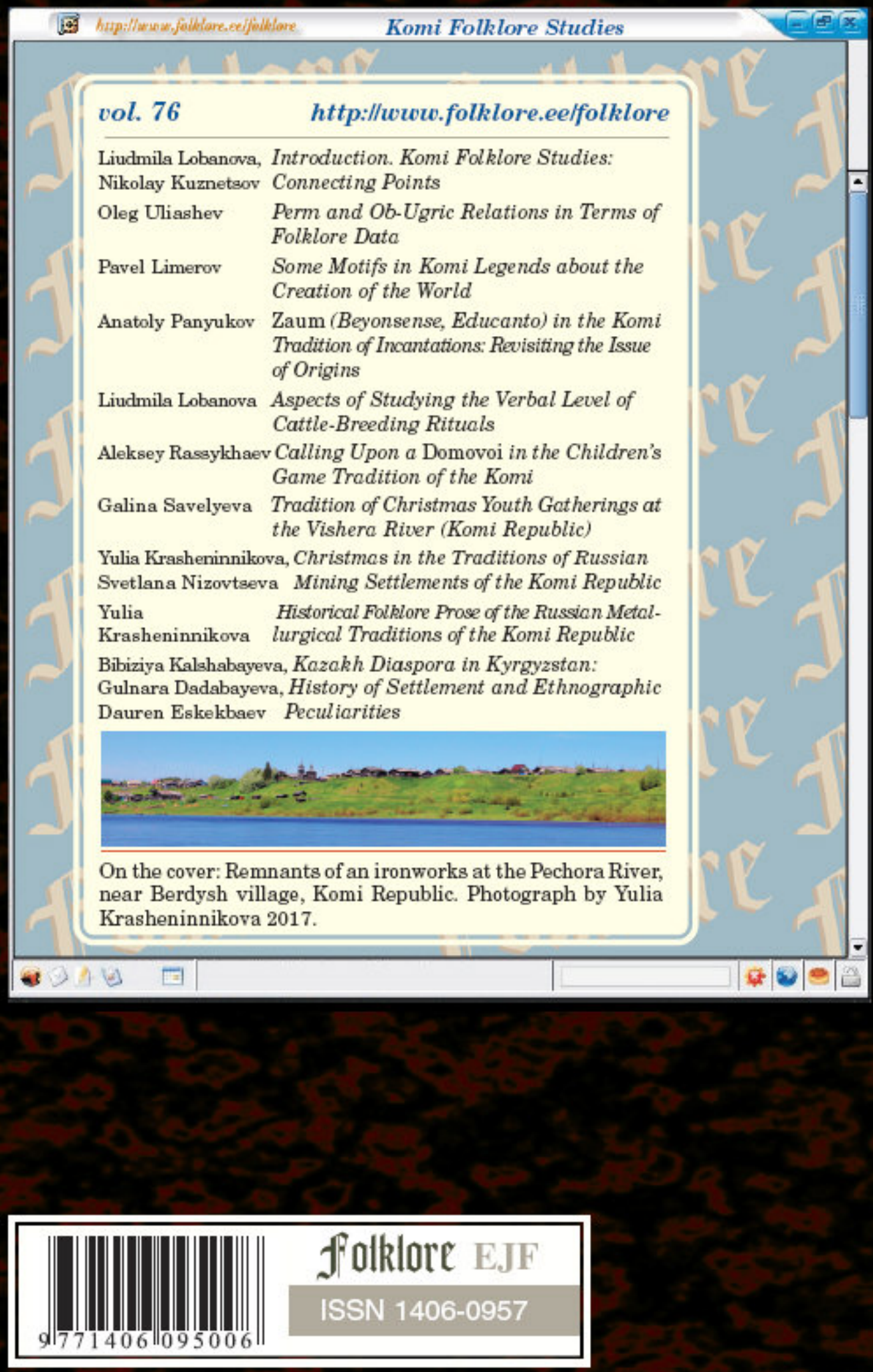